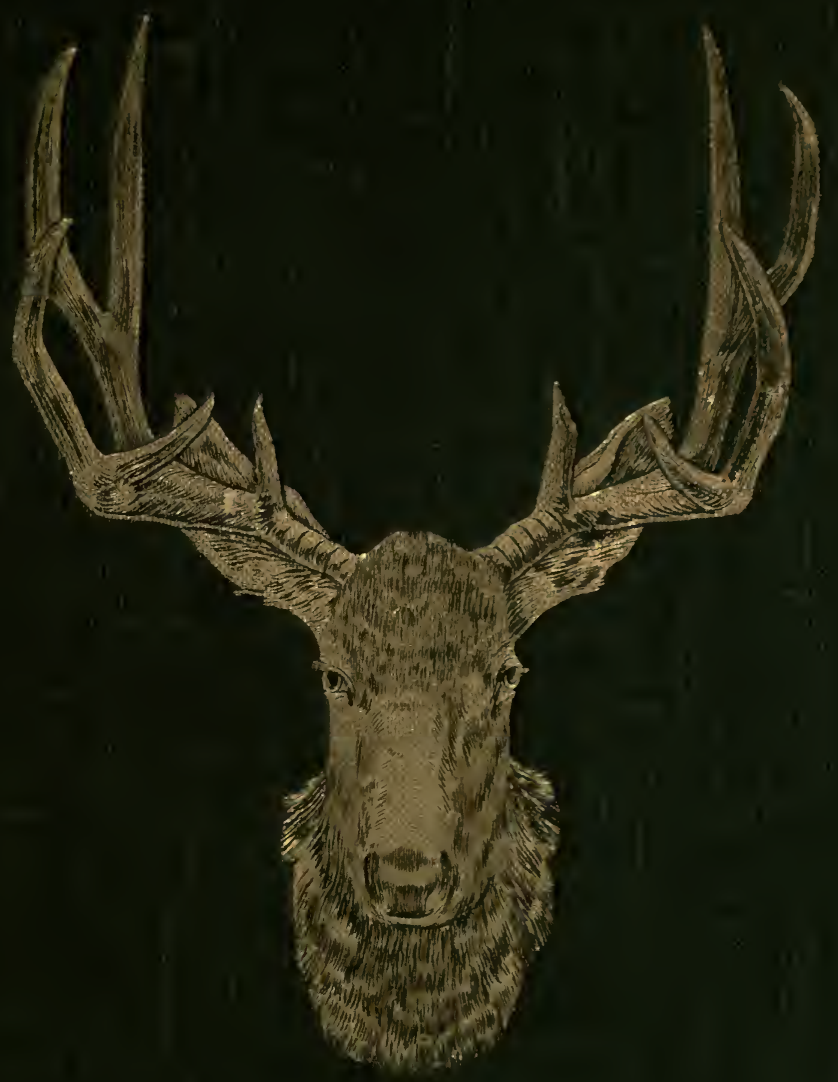

SPORT AND TRAVEL FREDERICK COURTENEY SELOUS 


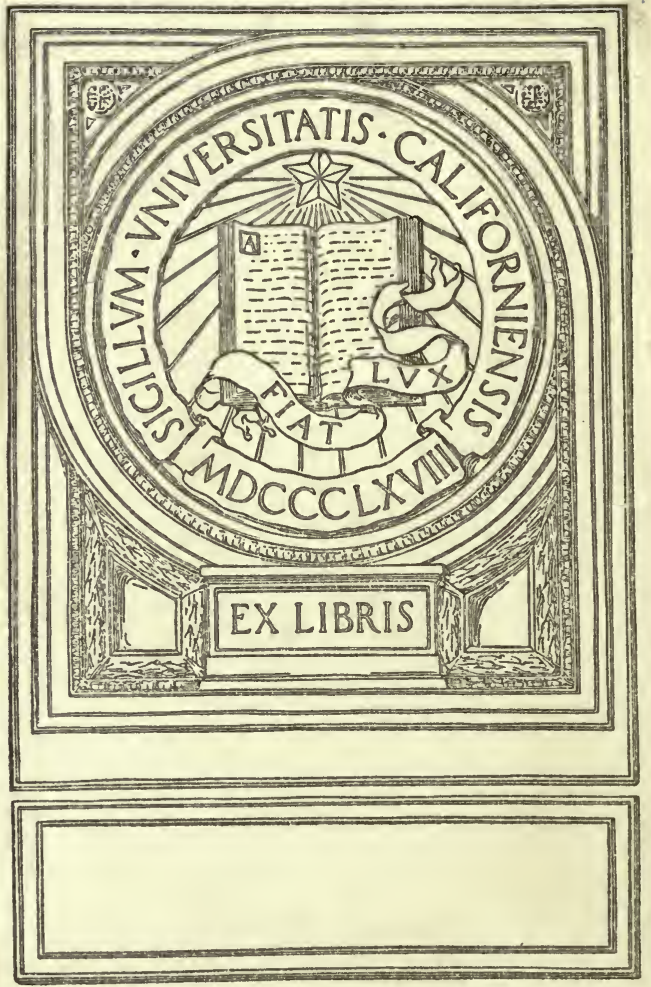



Digitized by the Internet Archive in 2007 with funding from Microsoft Corporation 


\title{
SPORT AND TRAVEL
}

\author{
East and West
}





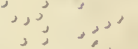

ת,

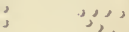

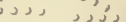

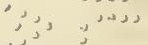

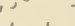


$\because \because$

$\therefore$ a.

$\therefore$ ㄴ.

ocs

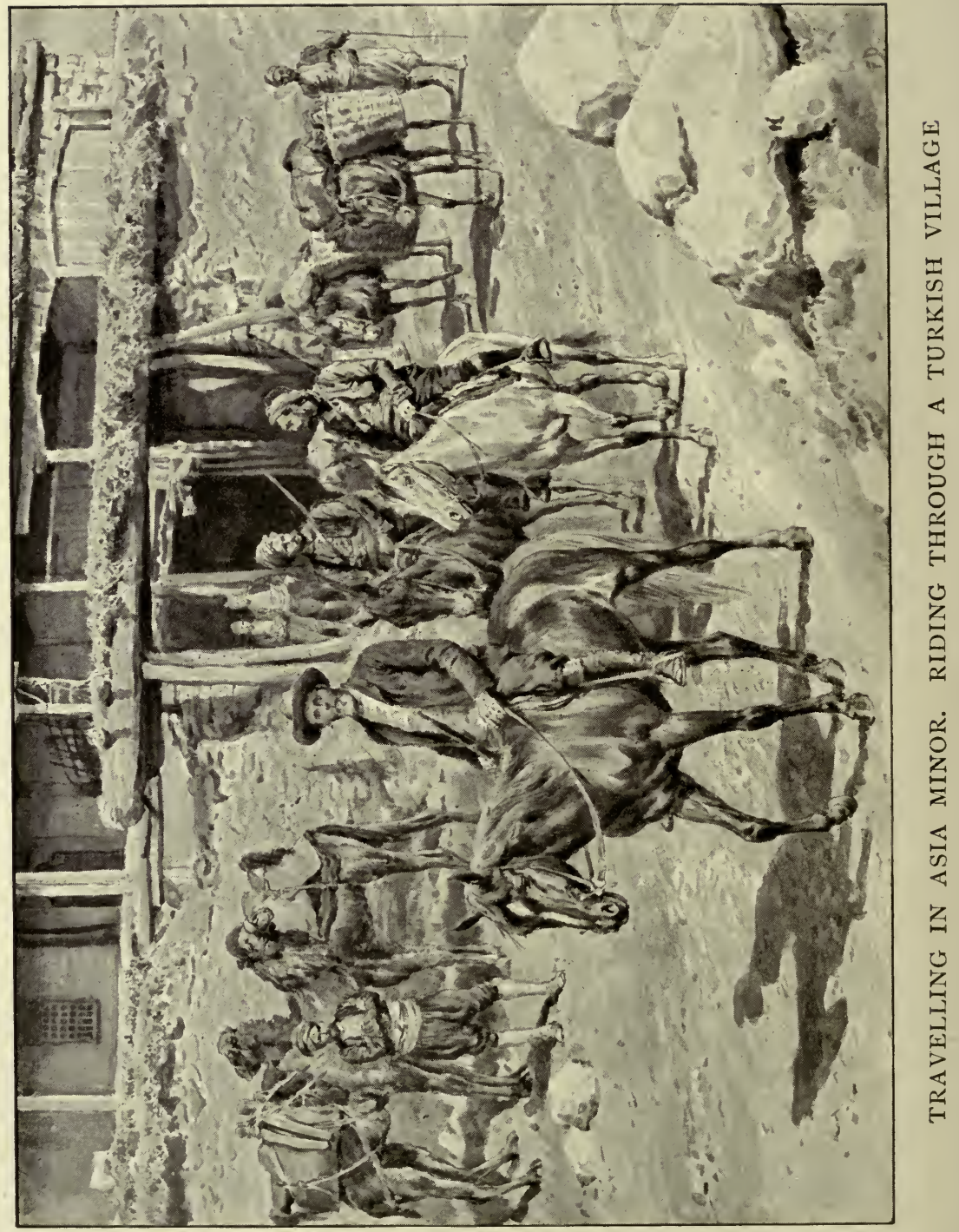




\title{
SPORT AND TRAVEL
}

\section{East and West}

\author{
BY \\ FREDERICK COURTENEY SELOUS \\ "A Hunter's Wanderings in Africa," "Travel and \\ Adventure in Soutb East Africa," \\ etc., etc.
}

ILLUSTRATED

LONGMANS, GREEN, AND CO.

39 PATERNOSTER ROW, LONDON

NEW YORK AND BOMBAY

I 901 
Copyright, Igoo

By F. C. Selous

All rigbts reserved

First Edition, May, ig00

REPRELNTED, MARCGद

$\because \because: \quad \because: \because \because 0^{\circ}$

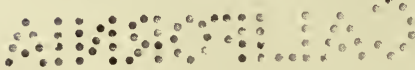

UNIVERSITY PRESS - JOHN WILSON

AND SON . CAMBRIDGE, U.S.A. 


\section{CONTENTS}

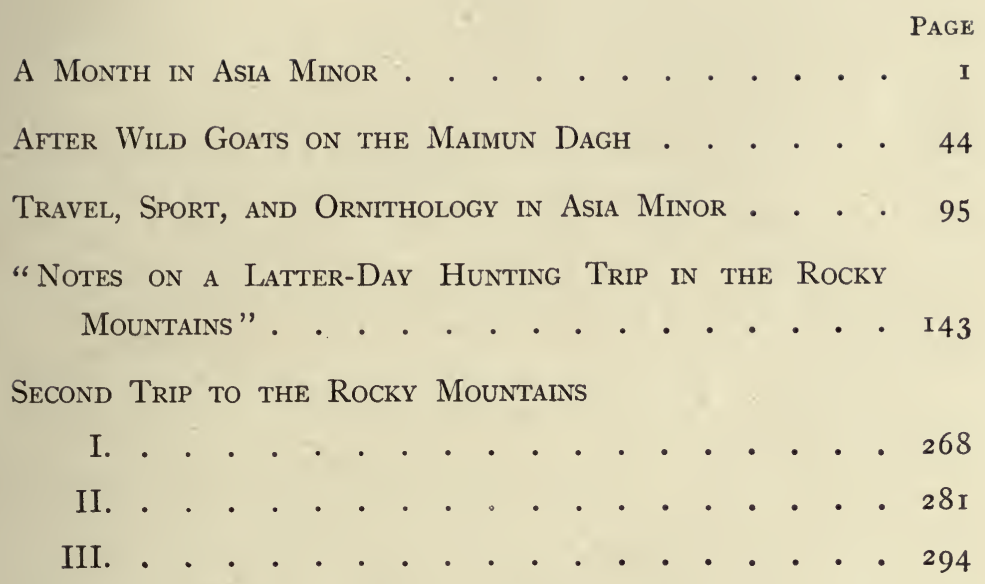





\title{
ILLUSTRATIONS
}

\author{
FULL PAGE
}

Travelling in Asia Minor. Riding through a Turkish Village Frontispiece

Swarthy Type of Turkish Peasant (Interior of Asia Minor) . . $\quad 8$

Yuruk Shepherd in Winter Dress (Note the armless felt coat) . . 48

Head of the Big One-horned Wild Goat of the Maimun Dagh

(Wounded on February 8, and found dead on February ıo,

I895） . . . . . . . . . . . . . . . . . 90

Yuruk Hunter . . . . . . . . . . . . . . . . IIO

Head of West Asiatic Red Deer (Cervus Maral). (Shot on the

Ak Dagh, Asia Minor, October, I894) . . . . . . . II6

Yuruk Shepherd Hunters of the Fair Type (Murad Dagh, Interior of Asia Minor) . . . . . . . . . . . . . . 120

When We saw Them, We were amongst Some Rocks slightly above Them . . . . . . . . . . . . . . 128

Return to Camp after a Successful Day's Hunting . . . . . . 132

Whilst Mustapha was Robbing the Eagle's Nest, I photographed Him from the Rocks Opposite . . . . . . . . . . . I 34

Head of Prong-horned Antelope (Shot near Dry Creek, September,

1897） . . . . . . . . . . . . . . . . 172

Head of Wapiti (Shot near Davies' Ranch, November, I897) . . 204

Head of Mule Deer (Shot October 8, 1897) . . . . . . . . 214

Head of Wapiti (Shot in the Cabin Creek, November, 1897) . . . 244

Head of White-tailed Deer (Shot in the South Fork of Stinking Water, November 4, 1897) . . . . . . . . . . 256

Canadian Lynxes Shot in the Rocky Mountains (Male shot I897;

female shot 1898 ) . . . . . . . . . . . . . 274 

Head of Wapiti . . . . . . . . . . . . . . . 288

Head of Mule Deer Stag (Shot on the North Fork of the Stinking

Water River, November I6, I898) . . . . . . . 302

\section{IN THE TEXT}

Turkish Village in the Interior of Asia Minor

Baggage Camel, Asia Minor . . . . . . . . . . . . I7

Camels that have just carried down Loads to the Railway Terminus 99

Country Cart with Turkish Driver in Asia Minor . . . . . . IOI

Portion of the Town of Ouchak; Interior of Asia Minor; with

Large Graveyard in the Foreground . . . . . . . . 105

A Street in Ouchak . . . . . . . . . . . . . 107

The Home of the Great Grey Stags, White Mountains, Asia Minor I 18

Beaver Dam on Duck Creek, near Bighorn, Wyoming, August, $1897 \quad$ I 46

View in the Bighorn Mountains, Wyoming, September, I 897 . . I 5 I

Scene in the Bighorn Mountains, September, I897 . . . . . I55

Prong-horn Buck, shot in the Bighorn Basin, September, I897 . . 164

Prong-horn Buck just brought to Camp, September, 1897 • . . . 166

The Valley of the South Fork of the Stinking Water River . . . 174

Davies' Ranch, South Fork of Stinking Water River, September,

1897 . . . . . . . . . . . . . . . . 176

Travelling with Pack Ponies up the South Fork of the Stinking

Water River; Crossing a Bit of Rock . . . . . . 178

Camp on the Divide at the Source of the South Fork of the Stink-

ing Water River; 10,500 Feet above Sea Level . . . . I 80

Dead Wapiti shot by W. M., September, I 897 . . . . . . . I 83

A "Park" in the Rocky Mountains; Pack Ponies Grazing during

a Halt, September, $\mathrm{I} 897$. . . . . . . . . . 185

Preparing to strike Camp in the Rocky Mountains, September, 1897 . . . . . . . . . . . .' . . . 187

Good Wapiti Ground in the Early Autumn . . . . . . . . 192

View in Rocky Mountains near the Head of the South Fork of the

Stinking Water River . . . . . . . . . . 196 
Scene in the Rocky Mountains after the First Snowfall, October, PAGE 1897 . . . . . . . . . . . . . . . . . 198

Just after the First Heavy Snow, October, 1897 . . . . . . 215

Striking Camp in the Snow, Rocky Mountains, October, 1897 • . 219

Young Wapiti Bull shot in the Deep Snow, October, 1897 . . . 231

Deserted Cabin at Old Mining Camp, Rocky Mountains, October,

1897 • • • • . . . . . . . . . . . . . . . 239

Settlers in the Far West, - Davies, Wife, and Father-in-Law . . 24I

The Home of the Prong-horned Antelope, Sage-Bush Plain, Bighorn Basin . . . . . . . . . . . . . 260

Valley of the North Fork of the Stinking Water River . . . . 272

View near our Camp in the Rocky Mountains, November, 1898 • 279

Scene near Camp in the Rocky Mountains, November, 1898 . . . 282

Tent pitched in the Shelter of the Forest. Frozen River in the

Foreground . . . . . . . . . . . . . . 298

Scene near Camp after a Light Fall of Snow, November, I898 • . 304

Scene of our Night's Bivouac in the Snow, November 20, 1898 . . 308

Open Water-Hole near Camp in the Frozen River . . . . . 310 



\section{SPORT AND TRAVEL}

\section{EAST AND WEST}

\section{§}

\section{A MONTH IN ASIA MINOR}

$\mathbf{M}$

$\mathrm{UCH}$ desultory reading on subjects connected with sport and natural history had given me a fair idea of the different species of large game to be met with in various parts of the world; and thus, when in July, I894, I found myself in Constantinople, I determined to try to obtain some precise information as to the habitat of the large long-faced red deer (Cervus maral) and the magnificently horned wild goats (Capra agagrus) that I knew were denizens of the adjacent country of Asia Minor. With this view I sent my dragoman down to the bazaars with orders to try to find out if there was any trade being carried on in deer horns, and if so, to endeavour to obtain precise information as to where the horns came from. The same evening he returned with the news that, although he had been unable to obtain any information on the subject in the bazaars, he had heard that an English merchant living in Stamboul had several pairs of deer horns in his possession. As my dragoman pronounced this gentleman's name in 
such a way that I could not quite make it out, but said that he could guide me to his office, I made no scruple about calling there on the following afternoon without any preliminary introduction, when I was fortunate enough to make the acquaintance of $\mathrm{Mr}$. J. W. Whittall, ${ }^{1}$ who, as he has himself lately contributed two articles to the "Field" on the subject of the red deer of Asia Minor, will, I trust, forgive the liberty $I$ take in mentioning his name in full.

Although an ardent sportsman, I found that at that time Mr. W. had never been after deer himself; but he was able to give me a great deal of information as to the districts in which they are to be found, and also promised to obtain for me further particulars from his brother, Mr. H. O. W., of Smyrna, who had shot both deer and wild goats in the interior of the country. With the most large-hearted hospitality Mr. W., before our acquaintance was half an hour old, invited myself and my wife to leave our hotel and become his guests for the remainder of our stay in Constantinople; and though I could not consent to this, I readily accepted an invitation to spend the following Sunday at his beautiful villa at Kadikoyi. During this visit Mr. W. showed me some very large pairs of deer horns from the Angora district of Asia Minor, and also several exceptionally fine specimens of wild-goat horns from the neighbourhood of Adalia, on the south coast. After seeing these trophies, I

1 Now Sir James Whittall, K.C.M.G. 
made up my mind to have a couple of months' hunting in Asia Minor in the following autumn, but acting on Mr. J. W.'s advice, delayed deciding upon my route until I had communicated with his brother, who was shortly expected in Constantinople on his way home from a visit to England. However, he had not arrived before I left Turkey, and I thought I should have to get all my information by letter, when, most strangely and most fortunately, we met in the Hotel Metropole, in Vienna, where at the same time I found two South African friends from the Transvaal. Mr. W. was travelling with his wife and mother, the former of whom had already accompanied her husband on some of his hunting trips, of which she gave my wife the most fascinating descriptions. The net result of this most fortunate meeting in the Vienna hotel was that, early in the following September, my wife and I found ourselves at Bournabat, near Smyrna, the guests of our most kind and hospitable friends.

At this time the weather was excessively hot, and it was rather too early in the season to go after deer, so I prepared to make a preliminary journey into the interior of the country in the hope of coming across mountain ranges frequented by wild goats, arranging to return to Smyrna in time to accompany Mr. and Mrs. W. to a well-known haunt of the red deer early the following month. Owing to the great heat, my wife did not accompany me on this first 
expedition, but remained the guest of our kind friends at Bournabat. I might have gone to good goat ground easily accessible from Smyrna, but I preferred to make a longer journey in order to see something of the country, taking my chance of finding game; and learning that there were some fine mountain ranges in the neighbourhood of the Turkish town of El Maly, which lies well in the interior, about half-way between the terminus of the Aidin Railway and the port of Adalia, on the south coast of Asia Minor, I resolved first to make for that place, and then be guided by circumstances. I was probably principally led to this decision by the fact that the man whom Mr. W. was giving me as guide and general factotum told me that he had himself seen wild goats on one of the mountain ranges near El Maly whilst engaged in searching for crocus bulbs for his employer in the previous spring, and as I knew that no European had ever hunted in the district, it possessed all the fascination of the unknown from a sportsman's point of view. Manoli, the guide aforesaid, a swarthy aquiline-featured hill Greek, grave and courteous in manner, I found to be a capital fellow and a most reliable and trustworthy servant. Dressed in his national costume, he always looked in harmony with his surroundings, which is more than I can say for Antonio, my Greek cook and interpreter, whose black pot hat, combined with the conventional jacket and trousers of Western Europe, was a constant eyesore 
to me. These two men were the only servants I took with me from Smyrna; and on Sunday, September 9, they were sent on ahead with the baggage to Denizli (the terminus of a branch line of the Aidin Railway), to hire ponies and get everything ready for a start on Tuesday morning for El Maly.

On the following day I started for Denizli myself, carrying in my pocket a letter of introduction to the Bey of El Maly, as well as my passport and a document which I had obtained from the Embassy at Constantinople, and which, I think, was an official letter from the Turkish Minister for Foreign Affairs, requesting on my behalf the good offices of all servants of the Sultan that I might meet during my travels. It was dark when the train at last reached Denizli; but I found Antonio and Manoli awaiting me with quite a good two-horse carriage, in which we all drove up to a small hotel kept by a Greek, who gave me a good supper and a comfortable bed. My men had got everything ready for an early start on the morrow, having engaged two men and five ponies to take us to El Maly, - two riding ponies for myself and Antonio, and three baggage ponies, which, although they seemed to me to be very heavily laden, had usually to carry Manoli and their owners on the top of the loads.

On Tuesday, September I I, we got the ponies loaded up before daylight, and made an early start, leaving Denizli at 5.30 A. M., and, although we made two short 
halts to let the ponies drink, their loads were not taken off their backs until half an hour after midday. Every country has its own customs, and thus, when on the occasion of the two short halts made to let the ponies drink, I at once took my English saddle off my horse's back, as one would do in South Africa, I was much astonished to see its Turkish master immediately replace it; and when my interpreter asked him the reason, he said that the horse was liable to catch cold if the saddle was only removed for a few minutes and then put on again.

The morning's travelling was pleasant, as before it became very hot we entered a pass through a range of hills down which a cool breeze was blowing. In the early morning I walked on ahead of the ponies, and in two and a half hours reached a fine spring of water pouring out from the base of a rocky hill. This is known as the Sultan's Spring; and here we found a Turkish soldier in a wayside guardhouse, who was very civil, and brought me a tiny cup of Turkish coffee. The road we travelled must, I think, have been an ancient caravan route, dating back to pre-Mohammedan times, as there had evidently once been a paved track, some four or five feet broad, right through the hills, reminding one of a street in Pompeii, though the stone-work was a good deal rougher. In places, for a space of twenty or thirty yards, portions of this ancient paved track still remained in perfect order, although the greater part of it had been more or less completely destroyed by the 
disintegrating influences of possibly over two thousand years of rain and sun and snow. During the whole morning we passed a continuous stream of camels, donkeys, and ponies, all heavily laden with merchandise of some kind or another. The long strings of solemn, slow-paced camels, all tied head and tail one behind the other, the front and rear animals always carrying great jangling bells, were invariably led by a diminutive donkey, on which sat a Turk, whose red fez, blue jacket, and white baggy trousers lent the touch of colour needed to add the picturesque to the strange novelty of the scene. About midday we reached the summit of the pass, and descending into a vast plain on its further side, at last off-saddled in the shade of a tree near a well containing a good supply of clear, cold water.

Here was a second guardhouse, occupied by a solitary Turkish soldier, who was very friendly, and soon brought me the invariable tiny cup of thick coffee to drink. Whilst we were enjoying our noontide rest in the shade, a large caravan on its way to Denizli halted beside us, and a most primitive cart, with wheels formed of one solid block of wood, and drawn by two buffaloes, was brought up to the well. The driver not only gave his animals water to drink, but poured a lot over them, an attention which the hot and dusty beasts seemed thoroughly to appreciate. Shortly before we saddled up, the Turks belonging to the caravan went through their devotions, each man taking off his shoes and spreading a carpet before him, on which he knelt and prostrated 
himself, touching the ground with his forehead repeatedly. These prayers occupied some time; and as I believe the followers of the Prophet are supposed to pray either five or seven times every day, the Mohammedan religion would have its disadvantages for a busy western European. Shortly after 2 P. M., we again got under way, and travelled over the heated plain at a sharp walk until half-past four, when we made a short halt at a village, where I purchased a few grapes, which, although small, were of delicious flavour, and most grateful after our hot and dusty ride. The heat on the bare, treeless plain had been really terrific, and I do not think I have ever experienced anything in the interior of Africa to beat it. In the evening we did two hours more at a slow pace, reaching the town of Adzibaden at 6.30, just at dusk, thus having done about ten hours' actual travelling, and covered about thirtythree miles of ground. The aneroid showed that we were now three thousand feet above sea level, and nineteen hundred feet higher than Denizli. The country through which we had passed struck me as far more arid and parched looking than any part of Matabeleland or Mashonaland that I am acquainted with, and the heat was certainly very great at the time of my visit. The people are very dark in complexion, being more swarthy than the Malays of Cape Town. Many of them, however, have a ruddiness of cheek which shows through the deep sunburn. Most of them have good features, whilst brown hair and light eyes are common amongst them. 


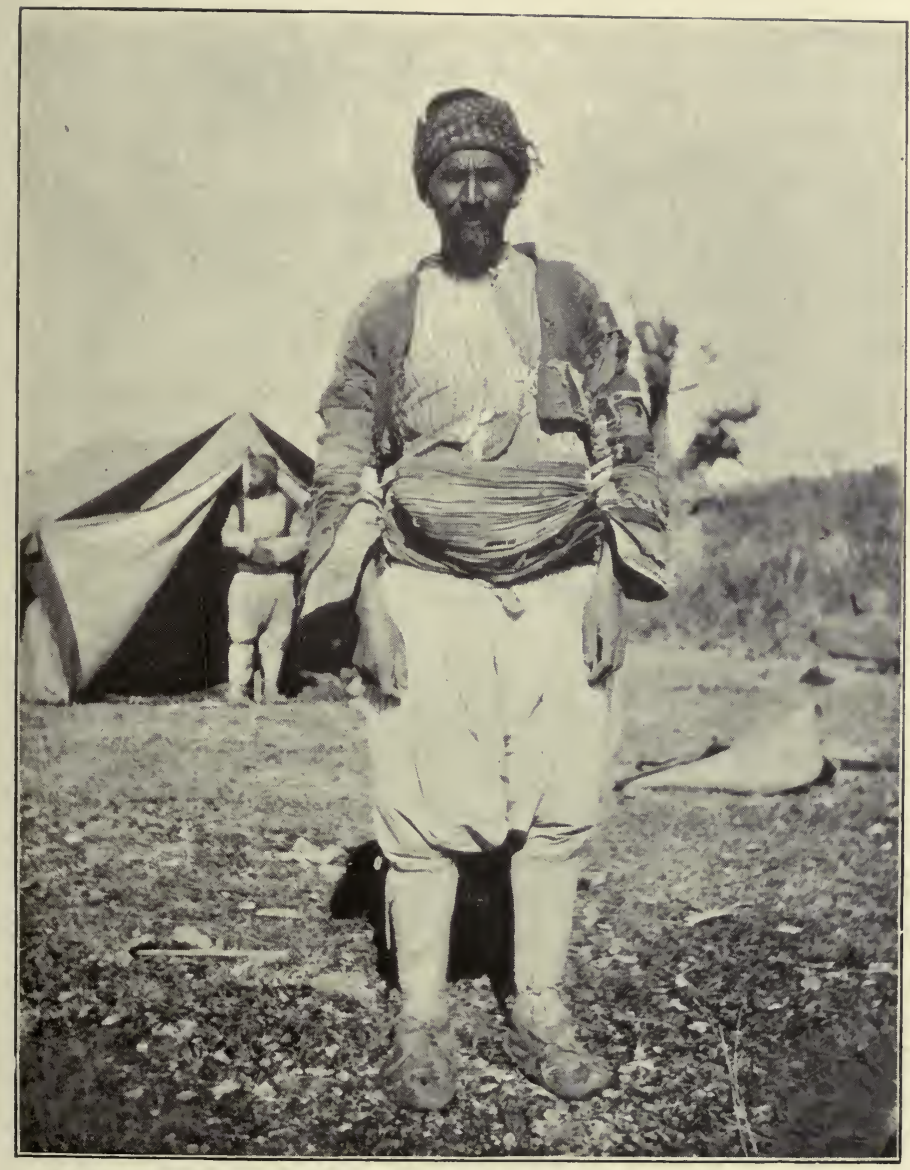

SWARTHY TYPE OF TURKISH PEASANT

Interior of Asia Minor 

Altogether, many of them look like the descendants of a fair-skinned race of people, burnt deep brown by exposure for many generations to a terrific sun.

After a hot day of riding and walking, I passed a most unpleasant night at a Turkish "han " or guesthouse in the town of Adzibaden. In the first place I could get nothing to eat, so cooked a little of the rice I had brought with me, and made a cup of tea. I slept in my own blankets on the roughly boarded floor of an empty room, or rather endeavoured to sleep, but without success, for all night long I was assailed by legions of bugs, that kept me in such a constant state of irritation that I was glad indeed when at last day broke and I was able to escape from their attentions. On leaving the room in which I had passed the night, and entering a paved courtyard enclosed within the guesthouse, I found the whole air pervaded with the most sickening stench imaginable, which arose from open cesspools serving as water-closets in the yard below the sleeping rooms. Why Adzibaden escaped the cholera epidemic then raging in certain parts of Asia Minor, I cannot imagine, unless the smells were too bad even for cholera or typhoid bacteria. The curious thing was that the people about the place did not seem to notice the dreadful smell. Glad, indeed, was I to once again breathe pure air beyond the precincts of this unsavoury town. We were rather late in starting, not getting off till after six o'clock, the delay being caused by my having to wait for my papers 
which had been required of me, immediately upon my arrival the previous evening by the chief of police, by whom they were submitted to the governor of the town. I had received a most civil message the same evening from this functionary, to the effect that my papers should be returned to me early the following morning, and that if I desired it, he would send an escort of four soldiers with me as far as El Maly. This offer I declined, as Manoli said the country was quite safe, and therefore an escort would only have been a source of more or less trouble and embarrassment. At last, after having been kept waiting for some time, with the ponies readyloaded, I received my papers, and we at once made a move. We travelled till past midday over a level burnt-up plain surrounded by hills. The journey was most monotonous and uninteresting, and the sun very hot. At I.3O, after an hour's rest, we went on again, and soon got amongst hills, when, a light breeze springing up, it became somewhat cooler.

In the course of the afternoon we passed through a very fertile piece of country all under irrigation, from strong streams running out of the surrounding mountains. Just at dusk we reached a small maize field, where an old Turk and his son were spending the night before a small fire; and as he was able to sell us some fodder for the horses, we camped alongside of his fire. Here I pitched my little Whymper tent for the first time, and passed a most comfortable night, as it soon became quite cool, and there were no insects to 
trouble me. On the following day we passed through a broken hilly country, seemingly uninhabited, and presently emerged upon a level circular plain of great extent, in the centre of which was a large and prosperous-looking village of some fifty wood and mud houses, or rather cottages, each of which was surrounded by a small orchard of apple and apricot trees. The plain surrounding the village was almost entirely under cultivation, and well irrigated, the water being led all over it from streams pouring out of the surrounding mountains, some of which must, I think, attain to a height of over seven thousand feet. In the afternoon we reached the summit of a pass fifty-five hundred feet above sea level. Although the sun was shining brightly in a cloudless sky, the air here was delightfully cool and pleasant, reminding me of the winter climate on the highest portions of the Mashona plateau. We were surrounded by mountain ranges, and I think I never looked upon a more harsh and desolate landscape, for in all the vast expanse of cold grey rock over which one's eye could wander, there was not a tree or a bush, or any apparent vegetation to be seen. Where we were standing, there was little or no grass; but I found that many little prickly spiny plants grew amongst the stones, and on these goats thrive well.

From the farther side of the pass we had a fine view of the Ak Dagh mountains. This range must look magnificent in winter when covered with snow, as many of its peaks and great rounded domes are ten thousand 
feet in height, but at the time of my visit there was not a vestige of snow upon them, and the whole range had the same burnt-up arid appearance as those we had passed through, and there was not a tree or a bush or any sign of vegetation to be seen anywhere upon them. Of course, this general view was deceptive, as I believe that there are considerable forests of pine-trees on some portions of the lower slopes of the mountains, which appeared to me to be absolutely devoid of any vegetation at all. As I have said above, in spite of the sterile and forbidding appearance of the country, goats thrive well on the various prickly plants which grow amongst the stones, and we passed several flocks of a fine large breed, all seemingly in excellent condition. The wild-looking unkempt Yuruk shepherds who tend them must be a hardy race. They are nomadic, living in tents made of camel's hair matting stretched on poles, which, although they look very flimsy, are said to be both strong and water-tight. Near the tent of one family was a patch of ground from which a crop of wheat or rye had been reaped, but so scanty was the soil, and so full of stones, that it seemed a marvel that it should ever have produced anything at all. Wild though these mountain shepherds were in appearance, and far removed from all the amenities of civilised life, they were dignified and courteous in manner, and never failed to offer us the best cheer procurable amidst their rude surroundings, - to wit, sour goat's milk. During the afternoon, whilst descending to- 


\section{SPO̊RT AND TRAVEL}

wards the plain beyond the pass, we saw a good many of the small hill cattle of Asia Minor, which reminded me a good deal of the native breed of cattle found in Mashonaland, and in the countries north of the Zam-

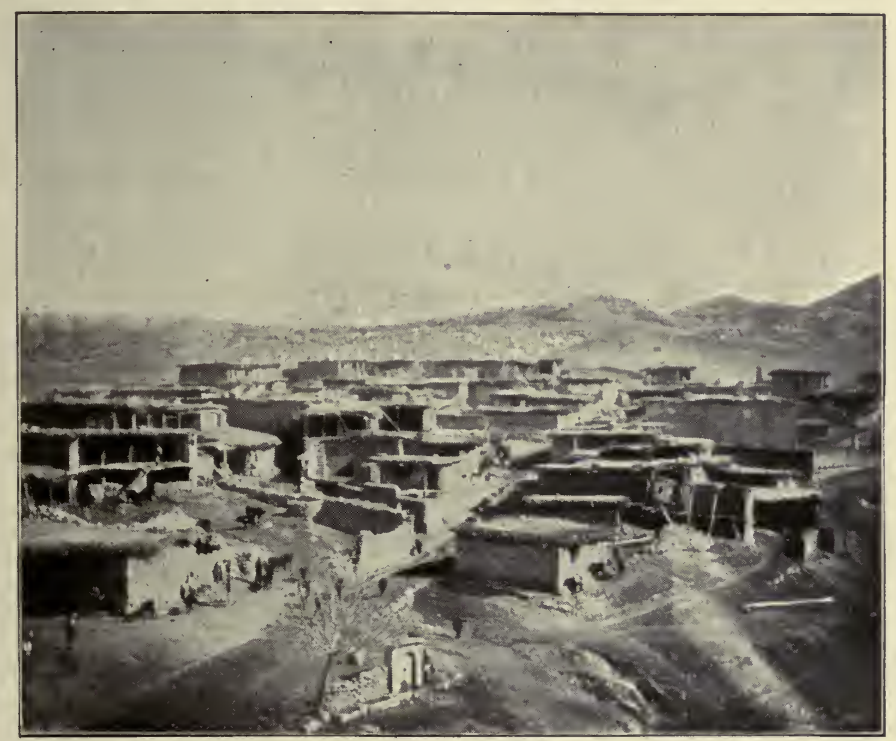

TURKish VillLage in the Interior of Asia Minor

besi ; the African breed is, however, the handsomer of the two, and somewhat less diminutive.

Towards evening we reached a small village at the foot of a steep hill, and, as the sun was nearly down, decided to camp, and on our wishes being made known to the head man, we were escorted by him and the entire village population to a small field immediately behind his cottage, at the bottom of which ran a 
strong stream of water. Here, beneath the spreading branches of a large tree, I pitched my tent, a dozen volunteers assisting in the operation. The villagers, who had probably never before assisted at the camping arrangements of a European traveller, showed as much curiosity in all our proceedings as I have often seen. evinced by the inhabitants of an African kraal when first visited by white men. The Turkish mountaineers, or Yuruks, were, however, far more hospitable than the generality of African villagers I have ever met, as they brought me many small presents of eggs and sweet and sour milk.

On Friday, September I4, after a walk of fifteen or sixteen miles, we reached El Maly. Having a letter to the Bey, or governor of the town, I went straight to his house, a large double-storied wooden building in the centre of the town. He was not at home on our arrival, nor did there appear to be any one about the place; but the man who had conducted us to the house said we had better off-load the horses whilst he went to look for him. This we did, and presently the Bey arrived, and on Antonio explaining to him that I was an Englishman who wished to shoot some wild goats in the mountains round El Maly, he at once escorted us upstairs, and put at my disposal a bare-boarded room (from which two large windows commanded a fine view over the town), where, before long, a very nice Turkish breakfast, consisting of boiled fowl and rice, and tomatoes stuffed with forcemeat, was placed before me. 
In every way I found the governor of El Maly most kind and civil. Before proceeding farther on my journey, it was necessary to hire fresh horses, as those which had brought us from Denizli had only been engaged to take us to El Maly; and on my telling the Bey that I wanted to go on as soon as possible, he at once sent a man out to hire fresh animals, but said that we should not be able to start till the following day.

On asking his advice as to the best place to make for with a view to hunting wild goats, he said he would not advise us to try the range where Manoli had seen goats in the spring, nor, indeed, any of the ranges close round El Maly, as although there were wild goats in all of them they were not numerous in any, and at this time of year especially difficult to find, because they were constantly disturbed by the Yuruk shepherds, who were pasturing their flocks of tame goats all over the mountains. The one place he knew of, he said, where wild goats were plentiful, was on the Musa Dagh and neighbouring mountains, situated on the sea-coast, about four days' journey southeast of El Maly; he said that if I liked to go there, he would give me a letter to the head man of the village in the district and also a soldier to escort us. On my replying that I would certainly take his advice and start for the Musa Dagh as soon as the ponies were ready, he further offered to give me a letter to a man named Achmet, an experienced hunter of wild goats, living about twenty miles from $\mathrm{El} \mathrm{Maly,} \mathrm{in} \mathrm{a} \mathrm{village} \mathrm{which}$ 
we should have to pass. Here I could spend a few days if I liked, as there were wild goats in the surrounding mountains with whose haunts and habits Achmet was well acquainted. He then showed me several skins of adult male wild goats, all whitish yellow in general ground colour, with the broad black shoulder-stripe which is so conspicuous in these handsome animals. These skins all came from the Musa Dagh, he averred, and were used for praying rugs, the skins of old wild goat rams being much prized for this purpose by the Turks of Asia Minor. He had no horns to show me, but measured off with his hands on a stick the length to which he said they attained, which worked out to forty-eight inches, - a very great but not improbable length. I was unable to get any information about red or fallow deer from the Bey or any of his attendants, and so presume that these animals do not exist anywhere in the vicinity of El Maly. Wild boar, however, he said, were numerous quite close to the town.

After a long chat, and with renewed promises that the ponies and the soldier should be ready early the following morning, our courteous host took his leave, retiring, I suppose, for a midday siesta, as the weather was still very hot. In the evening I took a stroll with Antonio and Manoli through the town, which presents many points of interest, as it has not been Europeanised in any way.

El Maly is built on the lower slope of a steep hill, 
and is surrounded by arid, treeless, stony mountains. It is wonderfully well supplied with water, however, one very copious stream running down through the centre of the town from the hills, and carrying a large volume of water to the plain below. There are so many fruit-trees growing in the gardens amongst the

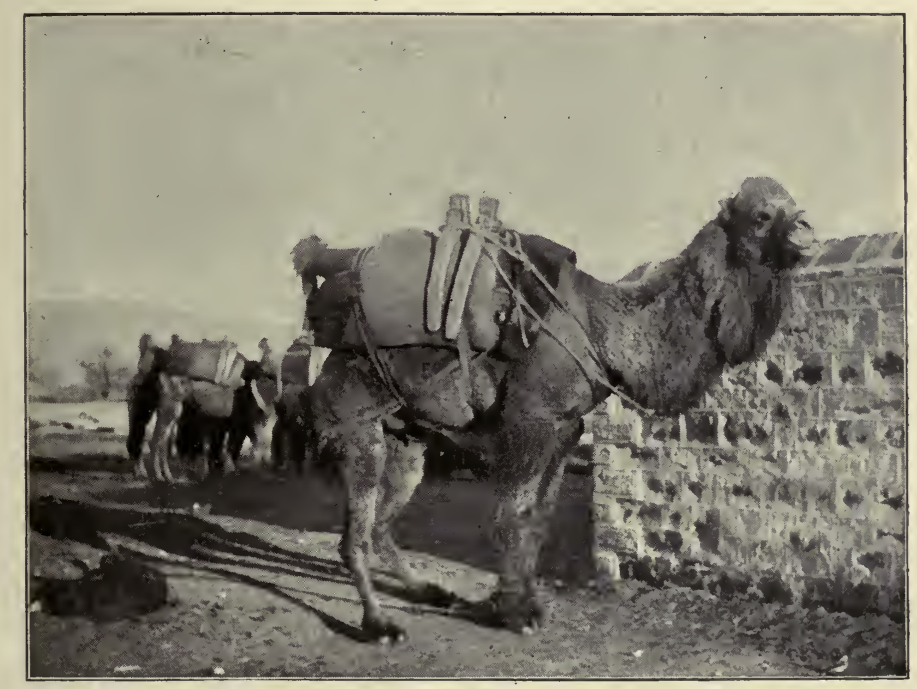

Baggage Camel, Asia Minor

houses that in the distance $\mathrm{El}$ Maly looks a veritable oasis in the desert, whilst in the plain below the town there are large orchards all under irrigation. The streets are narrow and steep, and roughly paved with cobblestones. They are altogether unsuited for wheeled vehicles of any description; and I do not think there is a carriage of any kind in the town, all 
merchandise being carried on the backs of camels and donkeys, strings of which animals are constantly to be met with. The houses - with the exception of a very few which are built of stone - are made either of large unburnt mud bricks or of wood. Most of them are two, and some three, stories high. There are several mosques in the town, the finest being the Mosque of Omar, a large stone-built edifice, with a fine minaret. Walking through the town late in the evening, we found the four entrances to the bazaar each guarded by a savage dog attached to a long chain, which allowed him to range from side to side of the street, and seize any one by the leg who might attempt to pass. These dogs are only on duty at nights, and save the expense of policemen.

We were up betimes the next morning, and had everything packed up ready for an early start; but it was some time before the ponies turned up, all in charge of one man, and past nine o'clock, and already very hot, when we at last said good-bye to our kind host, and clattered through the streets of El Maly, preceded by a mounted Turkish soldier, who was to act as our escort. After getting clear of the town we followed a very good road, which had been built some years before by the Turkish Government to connect El Maly with the port of Fineka. Not long after starting, we passed a huge cave at the foot of a range of hills into which a considerable stream of water poured itself and disappeared. Through my inter- 
preter I learned from the Turkish soldier that this was the Bashkos River, which runs for several miles in a subterranean channel under the hills before again reappearing. Later on we reached a fresh-water lake, several miles in circumference, along the shore of which the road skirted for some distance. On this sheet of water were thousands of coots, and a few large-headed wild ducks of a species which I could not determine.

Soon after leaving this lake, we entered a gorge in the hills, and, after a very hot four hours' ride, offsaddled at a kind of wayside inn, picturesquely situated amongst hills, which are all more or less wooded, presenting a strong contrast in this respect to the bare, arid mountains round El Maly. Whilst resting here several caravans of camels laden with goods from the port of Fineka passed along the road, and also some families of nomads, who reminded me somewhat of the gipsies I had seen on the lower Danube in the previous summer, though they were not so dark-complexioned as the latter people. As the women were not veiled in any way, they could not have been Mohammedans; and Antonio said they were not Christians. They were evidently moving from one pasture to another, as they were driving large flocks of goats before them, whilst all their household goods were being carried on camels, ponies, and donkeys. Some of the women rode cross-legged on donkeys, though most of the younger ones walked, and helped 
to drive the baggage animals. Fowls, turkeys, kids, and babies were scattered over the loads in more or less precarious-looking situations; and altogether the march past of these wild-looking, migratory people was as interesting to me as the sight of the Lord Mayor's Show would have been to them.

In the afternoon we reached Bashkos, a little Turkish village of a few wooden houses, picturesquely situated at the bottom of a ravine, on both sides of which rise mountains which attain to an altitude of from five to seven thousand feet. The river Bashkos (here a beautiful little stream of clear cold water) rushes noisily through the village, passing just below the house of the head man, - a very civil, goodlooking Turk, who proved to be the hunter Achmet, to whom the Bey of El Maly had given me a letter. On being questioned as to the chances of sport in the neighbourhood, Achmet declared that there were plenty of "gay-eek" (a word used to denote all kinds of game animals, but with Achmet meaning wild goats) in the surrounding mountains, and said he would go with me himself to look for them; so I put together a few things for a three days' hunt, and got everything ready for an early start on the following morning. Achmet then showed me several skins of goats which he had shot, and also the horns of a young ram about twenty inches long.

At daybreak next morning Antonio brought me a cup of coffee and a biscuit; and not long afterwards 
I commenced to ascend the steep hill above the village, accompanied by Achmet, Manoli, and three Turks carrying food and blankets. After a three hours' climb up the mountain, I was very much disgusted to find an encampment of Yuruks, especially as every man carried a gun. There being no water higher up the mountain, we here filled the wooden bottles we had brought with us, and then ascended another one thousand feet or so. Achmet and I then separated from the rest of the party, after he had first arranged to meet them at a certain place in the evening; but although we went over some excellentlooking ground, we did not come across any wild goats, and about 4 P. M. rejoined the rest of our party on the edge of a wild, precipitous ravine. Soon afterwards we saw a large flock of tame goats appear on the crest of a hill above us, - a sight which did not please me; for although I knew that wild goats and tame ones might live on the same mountain, yet I thought that the presence of the latter, together with their shepherds all armed with guns, would be sure to make the former very wary, and prevent them from coming out of the forest into open ground. We were standing just on the edge of the tree line, the mountains above us being quite devoid of either trees or scrub, while the slopes below were covered more or less thickly with pine forest, many of the trees being of very large size.

Achmet now made me understand that there were 
many wild goats amongst the wooded ravines below us, and that the best time to look for them was in the early morning and late evening. He then told off one of his men to go with me in search of them. As we started downhill, I imagined that we should have to return to where we had left Achmet later on; but I soon discovered that he and the other men were following us slowly at a distance. With my guide I now advanced very cautiously through the pine forest, looking carefully into all the ravines with which the side of the mountain was seamed; and when it grew so dusk that I could no longer see the sights of my rifle, we halted until the other men joined us, and then prepared to pass the night where we were. As we were on a very steep hillside, it was impossible to find a piece of level ground sufficiently large to accommodate us all. Indeed, there was no level ground at all; but I found a place behind the roots of a fallen pine-tree where I was able to make myself pretty comfortable. The ground we went over this evening looked excellent for any wild animal loving rocky ravines and pine-covered mountain slopes; but I take it that at the time of my visit there were very few wild goats on the mountain, as I saw very few tracks, and those always of single animals, none of them looking at all fresh. I came to the conclusion that there were too many hungry Yuruks about with guns to render it probable that any kind of game would be either plentiful or easily obtainable, so I determined not to 
waste more time, but to get back to Bashkos, and then push on to the Musa Dagh as quickly as possible, as the Bey of El Maly had particularly told me that at this time of year that mountain was not frequented by Yuruk shepherds. During the night we heard a wolf howling; and the Turks at once declared that the wild goats had been driven from their usual haunts by these animals, but I fancy the wolves about here do a better business amongst tame goats than wild ones.

On the following morning just as day was breaking, I rose from my bed of pine branches, and at once set out to hunt the other side of the mountain, accompanied by the same man who had been my guide on the preceding evening. Again the ground seemed excellent, the face of the mountain being cut into innumerable rocky ravines, with plenty of cover in them; but we saw no sign of wild goats or any other living animal, and at midday rejoined Achmet and the rest of our party at a rendezvous previously agreed upon. As the sun was now very powerful, and we had had nothing to drink since the previous evening, we had to make for water, which we did not get until we had reached the foot of the hill near Bashkos, where we arrived about three in the afternoon.

Next day, September i 8, we went on to Port Fineka, which we reached in the afternoon, after a hot ride of about twenty-five miles. The road followed the valley of the Bashkos River, which runs into the sea at Port 
Fineka. This road, connecting El Maly with the seaboard, must have been made at a great expense by the Turkish government not very long ago, and was, I believe, intended for the use of carts and waggons, and also for the transport of artillery and military stores. At any rate, when first made it must have been a broad, well-metalled road, suitable for wheeled vehicles of any kind. But once made, it was left to fate, and has never been kept up or repaired in any way. The consequence is, that at the time of my visit it was only fit for camel transport, as it had been so severely mauled by the overflow of streams rushing down from the mountain sides as to be impassable for anything on wheels. In one place, a cutting ten feet deep and six feet broad had been made clean through the road by a sudden rush of water down what was ordinarily a dry gully; whilst at another a large pinetree had fallen across it about a year previously, and of course had never been removed. Wherever these gaps and obstructions occur, the camel track makes a détour, so that this once well-made road is fast assuming the zigzag appearance of a Kafir footpath.

Between Bashkos and Port Fineka we saw some very curious tombs and temples cut out of the solid rock. They must, I imagine, date back to a very early period of Greek civilisation. On reaching Port Fineka, and finding that I could get round to the Musa Dagh more easily by sea than overland, I decided to send my escort and the baggage ponies 
back to El Maly, and endeavour to hire a boat to take me to my destination. I had very little difficulty in managing this, and soon succeeded in hiring a Greek fishing boat to take me and all my belongings to a place called Atrassan, near the Musa Dagh, wait there whilst I went up to the mountain for a week, and bring me back in time to catch the steamer for Smyrna, which I learned would call at Port Fineka some time during the night of Saturday, September 29. For this I agreed to pay $\$ 20$, which is equal to $£ 3$ 6s. 8d. in English money. Having made all arrangements, I went on board the same evening, and we got under way about midnight.

When day broke it was almost dead calm, and we were hardly moving, but upon rounding a promontory the breeze freshened, and soon became so strong that the skipper of our little craft was afraid to leave the shelter of the land, and we therefore beat about for some time under the lee of a ridge of rocks. In the afternoon we made another attempt, and, rounding the point, ran out into the open sea beyond, our boat tearing through the water under the influence of the strong breeze, and heeling over in such a way that the degenerate countrymen of Ulysses who manned it (although it appeared to me that we might have made a quick run to Atrassan without any danger in one tack) refused to proceed, and, hauling down the mainsail, put the boat about and ran her back to the shelter of the cove we had left. Here we remained 
until just before daylight the following morning, by which time the wind had died away almost entirely, so that we did not reach Atrassan till after midday. We anchored in a beautiful little bay close to shore, and, seeing some people on the beach, I at once landed in the dinghy with Manoli and Antonio. As it happened, the people we had seen belonged to the village, to the head man of which I had been given a letter by the Bey of El Maly, and, as the village was close at hand, he was soon summoned. I had no difficulty in making arrangements with him to at once search for wild goats on the rugged cliffs of the Musa Dagh, one end of which rises close to the Bay of Atrassan. He proposed, however, that I should camp at a spring of water on the slope of the mountain some miles further round the coast, and it was finally arranged that one of his men should proceed as quickly as possible to a certain bay just below the spring, with baggage animals to carry our camp outfit to the water, whilst he himself accompanied us in the boat to the place of rendezvous. The wind having now entirely dropped, we were forced to row, and it must have been quite three o'clock in the afternoon before we cast anchor in a little bay well sheltered from all but southerly winds. Here we found two baggage ponies and two donkeys awaiting us, and, at once disembarking, soon had all our camp baggage carried to a fine spring of water on the slope of a hill about five hundred feet above the beach. 
Whilst the camp was being pitched, the head man offered to take me to some good goat ground just above, and told us that the wild goats not only frequently drank at the spring, - the only water on the Musa Dagh, - but often went right down to the beach and drank sea water.

Late in the evening we reached a spot from which we commanded a view over a piece of ground, where a huge depression in the side of the mountain was split into a dozen rents and ravines, from the wooded sides of which great buttresses of rock protruded in all directions. Motioning me to sit down, the old man took a seat beside me, and, shading his eyes with his hand, eagerly scanned the broken ground above us. Suddenly he uttered the one word "Gray-eek" (wild goats) and pointed eagerly upwards. For some time, however, although my eyes are fairly well trained to see game quickly, I could not make them out; but presently I saw a small reddish object move across a wall of rock high above us, and soon made out two or three more, and, on looking through my field-glasses, counted six, all apparently ewes, with very small horns. I was still watching these ewes through the glasses, when a fine ram suddenly showed himself. He was a little in front of the foremost ewe, and almost immediately sprang across a narrow chasm, and stood in full view on a ledge of rock. He looked somewhat darker than the ewes, being still in his reddish summer coat; and I could see his horns quite distinctly. Being the 
first wild goat I had ever seen, these looked to me very large, though now I doubt if they could have reached thirty inches in length. The wind was very bad for a stalk, as it was blowing in puffs from below up the mountain-side, and it was too late to make a big détour and try to approach them from above. I was for leaving them alone and trying for them the following morning; but by a vigorous pantomime, which I took to mean that a bird in sight is worth two in the bush, my guide urged me to try to get a shot forthwith, so I made the attempt. I managed to get within two hundred and fifty yards of three of the ewes, but could not see the ram anywhere. Then came a puff of wind from behind, and the wild goats were off at once, the ram never showing himself at all. And thus unsuccessfully ended my first encounter with the "father of all the goats."

On the following morning I left camp at 5 A. M., accompanied by a young Turk named Mahmoud, who, the old head man said, was well acquainted with the haunts and habits of the goats. My young henchman carried a small wooden water-bottle and some dried figs and bread, whilst I was burdened with my rifle and cartridges. We had a very hard day on the mountain, not getting back to camp till 7 P. M. Early in the morning we saw a ewe and a kid within easy shot, but did not fire at them, and soon afterwards made out six more on the sky-line, on the edge of a precipice near the top of the mountain. These were 
all ewes with the exception of one young ram, whose horns were very much smaller than those of the one I had seen the previous evening. After this we went over a lot of ground without seeing anything more, but at last, when near the top of the mountain, we saw, on peering over the edge of a cliff, three, a young ram, a ewe, and a kid, lying on a piece of level ground almost directly below us. After carefully scanning the ground, I left Mahmoud, and tried to make my way to a spot from which, had I reached it, I could have got a shot at the ram at about one hundred yards' distance. This spot I almost reached, but not quite, as although I must have been within one hundred yards of my would-be victim, I was hidden from him by an overhanging ledge of rock, which I found it impossible to surmount. I was thus obliged to retrace my steps to a sloping wall of rock directly above the goats. This wall of rock was steep but not precipitous, and, being traversed with many little ledges and inequalities, was easy enough to climb over, the more especially as I had taken off my shoes. Presently I judged the distance that separated me from the goat to be about one hundred and seventy yards, and determined to try a shot, as I saw no chance of getting much nearer. I could now only see the young ram, the ewe and kid being hidden from me by bushes, but, as the former seemed utterly unsuspicious of danger, and there seemed to be no wind, I did not think there was any necessity for hurry, and thought I had better 
try to reach a tree growing on a ledge a little below me, the stem of which would have served as a rest for my rifle. I had just handed my rifle down to a ledge below me, and was preparing to follow, when suddenly the young ram stood up, and the next instant bolted, becoming instantly lost to sight amongst the rocks and bushes below him. He had either heard something, or an eddy of wind had brought him the scent of a Turk or a Christian above him, and he had not thought it necessary to stop and inquire what they were doing there. Well, it was the fortune of the chase, - one day with the hunted, and another with the hunter. I was much disappointed at my want of success, for, although I knew that the head of the goat, which with a lucky shot I might have secured, was not a big one, it would, nevertheless, have made a pretty trophy; besides which, continual want of success in a new country, and amongst people who do not know you, is more galling than it would be in an old hunting-ground, where one's followers know that the luck will average up in the end; for in a new country, if you are not successful at first, your men are apt to at once put you down as a duffer, and lose all their keenness to find game. After this we climbed up and down cliffs for the rest of the day, searching for wild goats in the ravines and corries, but saw nothing until when returning home, about an hour before sunset, and pretty low down on the mountain, we saw a flock of eight ewes and kids scampering along the rocks as 
if they had been alarmed. They were about four hundred yards from us, and I had a good look at them with the glasses, but there was no ram with them. It was quite dark when we reached camp, and I was not only very tired, but excessively thirsty, as the heat had been intense on the bare limestone rocks, and Mahmoud and I had had but a very small allowance of water between us. However, after I had had a bathe in the cool spring water, and drunk a kettle of tea, I felt all right again.

On the following day I was up at $4 \mathrm{~A}$. M., and left camp about an hour before dawn. A heavy thunderstorm was brewing, which I hoped might pass out to sea; but the black clouds came nearer and nearer, until at last the storm burst upon us, with heavy thunder and lightning, and deluges of rain. The young Turk, Mahmoud, who had accompanied me on the previous day, was again with me, and we sat under a bush for two hours, hoping the rain would cease; but as it showed no signs of doing so, we returned to camp to dry our things.

We had scarcely got back to camp when the rain ceased, so after a short delay we again climbed the mountain, and, on reaching the top, found it was just like a knife-blade, the further side being almost as precipitous as that facing the sea. For several hours we climbed about, searching all the ravines with the glasses for wild goats, but saw nothing. At length we returned to the near side of the mountain, and, late in 
the afternoon, on peering over a rock, I saw a female wild goat about one hundred yards away. I could see no others, and, as I wanted meat, and did not think there was much chance of getting a shot at anything else, I fired, and, hitting her right through the shoulders, killed her on the spot. At the report another ewe and a kid sprang into view for an instant, and then bounded away. The animal that I had killed proved to be a very old female, and I resolved to preserve her head, in order to have at least one souvenir of my trip to the Musa Dagh. By the time we had cut her up it was past five o'clock, and we had a lot of trouble getting down the mountain. Before it got absolutely dark, however, we managed to climb down the last precipice, and eventually reached camp about 7.30 P. M. Although I had only succeeded in killing a female goat whose head was but a poor trophy, a goat was a goat to my camp followers, and I could see that the fact that I had procured them fresh meat of any kind raised me very much in their estimation.

On the following day I remained in camp, as it was Sunday, and skinned and preserved the goat's head, which, poor trophy though it was, I thought it quite likely might prove to be the only goat's head I was destined to secure. In the afternoon, the wind being favourable, I went round the coast in the boat to a well-sheltered cove, known as Port Genoese. The scenery here is very remarkable, as rugged limestone mountains, culminating in the lofty peak of 
Takhtali, rise sheer from the sea, whose marvellously deep blue colour, at the very foot of the cliffs, proves the great depth of the water. The general appearance of these mountains overhanging the sea is one of bare grey rock, sparsely dotted with dark-foliaged fir-trees, but a more careful inspection shows that, wherever ravines occur, their sides are thickly wooded, and often covered with dense scrub. The Greek fishermen who manned our little boat informed me that upon several occasions, when they had put in here for water or shelter, they had seen wild goats on the crags above; and I do not doubt that they were speaking the truth, as no ground could have looked more favourable for these shy animals than the rugged cliffs of this wild and uninhabitable coast. In the evening, accompanied by Mahmoud, I climbed up some likely looking ravines, but, although we saw fairly fresh spoor, we came across no wild goats, and so we returned to the sea at nightfall, and slept on board the boat.

On Monday, September 24, leaving the boat to find its way back to its old anchorage beneath the shadow of the Musa Dagh, Mahmoud and I climbed the mountain above the bay, and then commenced to work our way slowly westwards across the broken country that lay between our camp and Port Genoese. The heat was intense, the sun beating down in such pitiless intensity from a cloudless sky upon the bare limestone crags, over which we cautiously made our way, that I at length began to feel as dry and parched up as my 
surroundings, which I could not but compare unfavourably with the well-watered hunting-grounds of Eastern Rhodesia, which I had but so lately left. At last, about midday, we saw four female wild goats in a ravine below us; and despairing of seeing any rams, and in the hope of securing fresh meat, I decided to try a shot at one standing on a rock almost perpendicularly below me. She was about one hundred and fifty yards distant, and standing perfectly still; but I missed her clean, the bullet striking with a loud smack the rock on which she was standing. She evidently did not know where the shot came from, for instead of bolting downhill, as these wild goats usually seem to do, - a course which in this case would have meant safety, - she came clambering up towards me; so hastily slipping another cartridge into my rifle, I got a second chance at her as she passed at about eighty yards' distance. She showed no signs of being hit, but rushing through a patch of bush disappeared behind a rock. This point I soon reached, and at once saw such a heavy blood-trail stretching across the rocks in front of me, that I thought my bullet must have cut the animal's throat, and expected to find it lying dead within a very short distance. However, in spite of the great loss of blood, this sturdy little animal led us a long chase, and eventually evaded us, though I fear it could never have recovered from the serious wound it must have received. We had followed it for some distance over some very rough 
ground, when we came upon it suddenly, lying within ten yards of us under a bush at the bottom of a little gully. It did not give me a chance of a shot, as it rushed away under cover of the bank. Up to this point the spoor had been very easy to follow, but beyond it there was very little blood. After following the tracks slowly and carefully some distance farther, we at last lost them amongst some scrubby bush, and finally abandoned the pursuit, only reaching camp late in the evening, dead tired and parched with thirst.

In the evening I had a long talk with the old head man of Atrassan; and learning that there was a mountain a few miles round the coast to the westward, often frequented by wild goats at this season of the year, I determined to shift my camp altogether to a place called Markos, as it seemed to me that although there were a good many ewes and kids on the Musa Dagh, big rams were excessively scarce there, and might prove to be more plentiful on the new ground. Anyway, it was a chance which I resolved to try, as the time I could devote to wild-goat hunting was fast drawing to a close, if I was to catch the steamer leaving for Smyrna on September 29. Thus, on the following morning, I got everything carried down to the boat, and, the wind serving, embarked forthwith with my two Greek servants, the old head man and Mahmoud also accompanying us. About one o'clock we reached Markos, and as the mountain on which we hoped to find the wild goats rose sheer from the sea, 
like the mountains of Port Genoese, I at once landed, and, taking Mahmoud with me, went a good way up the mountain, not getting back to the boat till an hour after dark. We saw two small goats, either females or very young rams, in the course of the afternoon, but as they were not worth shooting, I did not attempt to stalk them.

On Wednesday, September 26, I started at daylight with the boy Mahmoud, Antonio, Manoli, and the head man of Atrassan, accompanying us, and taking a few things, necessary to form a camp at a spring on the mountain-side about five hundred feet above the seashore. Arrived at the water, they remained there with their loads, leaving Mahmoud and myself to proceed on our way upwards. We had a long day, going right over the mountain and hunting many fine cliffs on the farther side, and not getting back to camp till 7.30 P.M., fourteen hours after leaving the boat in the morning. The heat of the sun was something terrific, especially in the morning, as there was not a breath of air, and the fierce sun beating down on the bare rocks was as hot, I think, as anything I have ever experienced in Africa. On this day, too, as on previous days on the Musa Dagh, we suffered much from thirst, as, except at the springs found close to their bases, all the mountains in this part of Asia Minor are absolutely waterless. I carried my rifle and Mahmoud a small wooden bottle of water, but by midday this was emptied, and we should have suffered much from thirst 
in the latter part of the day had it not been that by that time we had reached the top of the mountain, and in the afternoon a breeze came up from the sea, which mitigated to some extent the intense heat. This was another blank day, as we did not see a wild goat of any sort, though there were evidently some about, as was proved by their spoor and droppings, so I still hoped for better luck on the morrow. The old head man seemed much put out at my not having seen any goats, and accused Mahmoud of not having carried out his instructions and taken me to the best places to find them. I do not think the boy was at all in fault, as we had been over some very excellent-looking ground and seen a good deal of spoor, though we had not had the luck to actually sight game. Finally, the old man said that on the following day, which would have to be my last on the mountain, he would accompany me himself, and, if Allah so willed it, would get me a shot at a good goat.

In order to take full advantage of the cool of early dawn, I was astir before daylight the next morning, and, accompanied by Mahmoud and the head man, commenced to climb the mountain-side just as day was breaking. It was still early when we reached the summit, and here we had a rest, and enjoyed a frugal meal of biscuits, dried figs, and water. So far we had seen nothing, but the old Turk seemed full of confidence, and, after our rest, again led the way along a spur of the mountain running towards Atrassan. 
The face of the mountain upon which we were now hunting was cut into a succession of rocky ravines, divided one from the other by ridges more or less clothed with pine-trees and scrubby undergrowth; and it was evident, from the cautious manner in which my old guide examined every open piece of ground, that he fully expected to see some of the animals of which we were in search in one or other of these numerous ravines. Nor was he mistaken; for at last, after peering over a rock into the depths of a deep gorge below us for several minutes, he turned and beckoned me to come to his side, at the same time giving utterance to the one word "gay-eek," - wild goat. Unless it had happened to move just as my eye fell upon it, I should certainly have overlooked it, had I been alone and without my field-glasses. By the aid of these, however, I could see quite plainly, not only that it was a wild goat, but a ram with fair-sized horns, lying apparently fast asleep amongst a lot of stones in the shade of a large fir-tree. I soon made out a second goat, also a ram, lying near the first, and presently my strong field-glass revealed a third, apparently a female, lying on a ledge of rock at some distance from the other two. We were, as I have said before, a long way above them, but as the wind was in our favour, I think we might have descended the side of the mountain by the next parallel ravine, and then have crept to within easy range of where the rams were lying, if they would but have prolonged their siesta for another hour or two. 
Before, however, we had decided upon our plan of action, first one ram, and then the other, rose to his feet, and, after being joined by the small female, commenced to move very slowly and deliberately across the chaos of rocks and stones amongst which they had been lying. They soon crossed this open ground, and getting amongst some scrubby bush, disappeared from view. I thought they would soon show themselves again, and indeed I deemed it not unlikely they would ascend the spur of the mountain at the foot of which they had been lying, and come right up of their own accord to within shot of where we were sitting. It looked the natural thing for them to do. However, minute after minute passed, and we saw nothing more of them, till at last it seemed evident that they had again lain down in the shelter of the bushes amongst which we had lost sight of them. The old Turk now made signs that he wished me to work down on to them, but I was loath to move, as it is one thing to stalk an animal whose exact position you know, but quite another to approach a patch of bush in some part of which you know that an animal is lying concealed without being sure of its exact position; as in the latter case the odds are ten to one that you are yourself seen first, in which case, if you get a shot at all, it will not be a good one. So I waited and waited and waited, till at last the position of the sun warned me that if I was to shoot a goat and get back to camp before nightfall, I must make a move. 
The descent of the mountain was easy enough; and before very long we had got down to the neighbourhood where we had first seen the goats lying, and the old Turk gave me to understand that if we reached a certain buttress of rocks we should command a view of the spot where we had last seen them. Before reaching these solid rocks, however, we had to cross one hundred yards or so of loose stones; and to accomplish this noiselessly was an absolute impossibility, as they lay all loosely heaped together at a steep angle on the mountain-side in such a way that the displacement of one moved several others and was bound to make some slight noise even if it did not send a small avalanche down to the valley below. Across this treacherous piece of ground my guide and I moved cautiously with bare feet; at least his feet were bare and mine only covered with socks. It seemed that it took an age to cross it, but at last we reached the solid mass of rocks that had been our goal, and, climbing hastily to the top, eagerly scanned the ground beyond, and almost immediately saw the wild goats of which we were in search. Fortune so far had befriended us, as, although the slight noise we had made in crossing the loose stones had disturbed them, they had not been able to quite locate the sound, and were approaching us instead of retreating. Had we not disturbed them, I do not think we should ever have seen them at all amongst the bushes where they had been lying, until they had made us out, and crept away without offering a chance 
of a shot. 'As it was, they were at first about three hundred yards below us, but as they were climbing upwards every step brought them nearer to us. They advanced very slowly, and with great caution, until at last they were within two hundred yards of where I stood. Nearer than this they were not likely to approach, so, putting up the two hundred yards' sight, I prepared for a shot. The two rams appeared about the same size, and their broad curving horns looked very fine. Soon one of them stood in full view on a rock, and offered a capital shot. Standing as I was, he was too far off for me to feel at all sure of hitting him; but Allah was with me on this day, and as I fired I had the satisfaction of seeing him fall headlong off the rock, and disappear in a small crevasse. I very nearly got a shot at the second ram, as he jumped from rock to rock, but he was a little too quick for me, and got out of sight before I could manage to slip another cartridge into my singlebarrelled rifle. Barefooted as I was, it did not take me long to get down to where my prize lay. The old Turk pronounced it to be a five-year-old ram; and, such as it was, I was very pleased to have secured it, for, although its horns had not attained to the magnificent proportions sometimes seen in old rams of his species, he still carried a very pretty head, his horns being quite symmetrical, and measuring just twentyfour inches over the curve. He was still in his summer coat of red brown, with a short black beard, but with the broad shoulder-stripe, which becomes so con- 
spicuous later on in the season, almost entirely wanting. His legs were short and strong, and well suited to carry their owner's heavy though symmetrical form up and down the mountain-sides on which he had passed his life. He was in excellent condition, and his flesh proved surprisingly good, quite equal, it seemed to me, to the best of mutton, and without any trace of goaty flavour about it. I would much rather, however, have had a good stinking old ram with a real big head. It did not take us long to cut him up; but it was already late when we started for camp, which we did not reach till after dark.

On the morning of the following day we were unable to make sail for Fineka, as the wind proved unfavourable, so I skinned and preserved my goat's head, and then had everything carried down and packed in the boat, all ready for a start as soon as the wind changed. But all day long it blew steadily from the same direction, until I began to fear that we should miss our steamer. The Greek boatmen, however, declared that there would be a change at sunset, and they were right, as the wind dropped altogether about that time, leaving us still stuck for the want of any wind at all. A little before midnight, however, a breeze sprang up from the east, and we at once got under way, and reached Fineka about one o'clock on the following day.

That same night our steamer arrived from Adalia, when we at once went on board, and were soon on our 


\section{SPORT AND TRAVEL}

way to the famous island of Rhodes, which we reached on the afternoon of September 30. Here we were put in quarantine for eighteen hours, and so did not arrive at Smyrna until late on the afternoon of October 3 , thus bringing to a close my first journey in a (to me) new and most interesting country, where if I had not had much sport, I had spent a pleasant time in quest of it, and gained experience which may be useful to me at some future time. 


\section{AFTER WILD GOATS ON THE MAIMUN DAGH}

7 OWARDS the end of January, I895, having six weeks at my disposal, I determined to make a quick rush to Asia Minor in the hope of getting a shot or two at wild goats (Capra agag$r u s)$, or even, if time permitted, endeavouring to secure a specimen of the little-known moufflon (Ovis gmelini) of that country. Having spent two months in Asia Minor in the previous autumn, I knew something of the country, and of the haunts and habits of that handsome animal which Mr. E. N. Buxton has so happily described as the father of all the goats; and, moreover, being in communication with the kindest of friends in Smyrna, I could count upon the best advice and assistance in carrying out the object I had in view, with little or no preliminary delay. At the last moment I found myself without a rifle, $-\mathrm{my} \cdot 45^{\circ-}$ bore Metford, by Gibbs of Bristol (which I had used on my last trip, and for many years previously), having been most unaccountably lost by the Austrian Lloyd Company between Smyrna and Budapest. I was expecting daily to hear that this rifle had been returned to my friends in Smyrna, and was naturally 
unwilling to go to the expense of purchasing a new weapon; but even up to the day of my leaving England for Africa, on March 30, I895, the lost rifle had not been recovered.

Leaving England on January 25, and travelling by way of Marseilles, I reached Smyrna on February 2 in the steamer "Alphée," one of the oldest, smallest, and slowest boats of the French Messageries Maritimes line. We were two days behind time, having encountered very bad weather in the Mediterranean; but even had we arrived at our destination on the appointed day, I consider that this route to Asia Minor has nothing to recommend it but its comparative cheapness, as I found the long sea-passage very tedious in a small and by no means luxurious steamer. I had with me a pretty little sporting .303 Lee-Metford rifle, kindly lent to me for my trip by Mr. Henry Holland, the well-known rifle-maker of New Bond Street, and feared I might experience some trouble in landing it at Smyrna, as I knew that the Turkish custom-house authorities - always troublesomewould now be more than usually obstructive, owing to the attitude taken up by the principal European nations on account of the recent excesses of the Turkish troops in Armenia. However, I was saved from all difficulties through the kindness of my friend Mr. Fred. Holmwood, our Consul-General at Smyrna, who, being notified of my arrival, came on board the "Alphée" to meet me, and took all my baggage 
through the custom-house for me. A short chat with the Consul soon convinced me that in the present disturbed state of the country, and the irritable and excited condition of the Turkish authorities, it would be very inadvisable to try for moufflon in the country where these animals are to be found, owing to its proximity to the Armenian frontier; and my choice of hunting-grounds therefore lay practically between two districts, - the Maimun Dagh to the east, and some hills in the neighbourhood of Makri to the south.

After breakfasting with Mr. Holmwood, I made my way to the office of my kind friends, the W's., by whom I was handed a telegram, which, although it did not necessitate my immediate return to England, still rendered it advisable for me to considerably curtail the number of days that I had originally thought I should be able to devote to actual hunting. This left me no alternative but to make for the Maimun Dagh, or Monkey Mountain, which, situated as it is right alongside of the Aidin railway line, is the most accessible haunt of the wild goat in Asia Minor. Mr. H. O. W. had got everything ready for me, and on the morning of February 3, the day after my arrival in Smyrna, I took my ticket for Chardak station, which lies right under the Maimun Dagh. I was accompanied by two Greek servants who had been with me the previous autumn, and with whom I felt quite at home - Pabli, who acted as cook and interterpreter, and Manoli, a very useful all-round man. 
Pabli I always found a most good-tempered, willing, and obliging man, and a very fair cook. He knew a little Italian, and less French, whilst I knew some French and no Italian, and I think we mutually comprehended one another in a broad way as much by instinct and intuition as by language; yet I could always make out what Pabli was driving at (sooner or later), whilst he professed to understand my French illumined by shots at Italian words, molto bene.

At Chardak, I was met by an old acquaintance, a Greek doctor in the employ of the railway company. No one is better acquainted than Dr. C. with the haunts and habits of the wild goats of the Maimun Dagh; and I was very pleased to find that he would be able to spend the next ten days with me, and give me the benefit of his local experience in outwitting one of the wariest of wild animals. Though somewhat rotund of figure, the good doctor is an excellent walker and climber, a keen sportsman, and a good shot; but only possessing a smooth-bore gun, it is but seldom that he can hope to get a shot at the wild goats except by having them driven to him by beaters, when the animals often pass within a short distance of the concealed hunter. In this way the doctor has shot a good many, amongst them some fine billies; though he has never secured one of the very largest size, as these wary old veterans, I believe, always refuse to be driven, and break back through the line of beaters. 
As it was already late in the afternoon when the train reached Chardak, and Dr. C. had to return to his home at the other end of the mountain to get his blankets, etc., before finally joining me, I arranged to stop at the station until his arrival the following morning by the down train from Dinair, due at Chardak at $8 \mathrm{~A} . \mathrm{M}$. He and I were then to have a day in the mountain, whilst Pabli and Manoli would get our tents and baggage conveyed on a bullock cart to a spring of water at the base of the mountain about five miles from Chardak, where they were to pitch camp and have everything ready to receive us at the end of our day's tramp. On this evening I was the guest of the hospitable Greek station-master and his family, who were all suffering from malarial fever, the effects of which they were endeavouring to mitigate, they told me, by daily doses of quinine. As Chardak stands at an elevation of about three thousand feet above sea level, and as at the time I am speaking of the nights were cold and frosty and the days by no means too warm, one would not have thought that the climate ought to have been feverish; but I expect that the station-master and his family had originally caught their fevers in the summer months, when the exhalations from the large salt pan lying at the foot of the Maimun Dagh must be very unhealthy; and a malarial fever once caught is often difficult to get rid of, as some of us know from personal experience.

When nearing Chardak I had seen from the train 


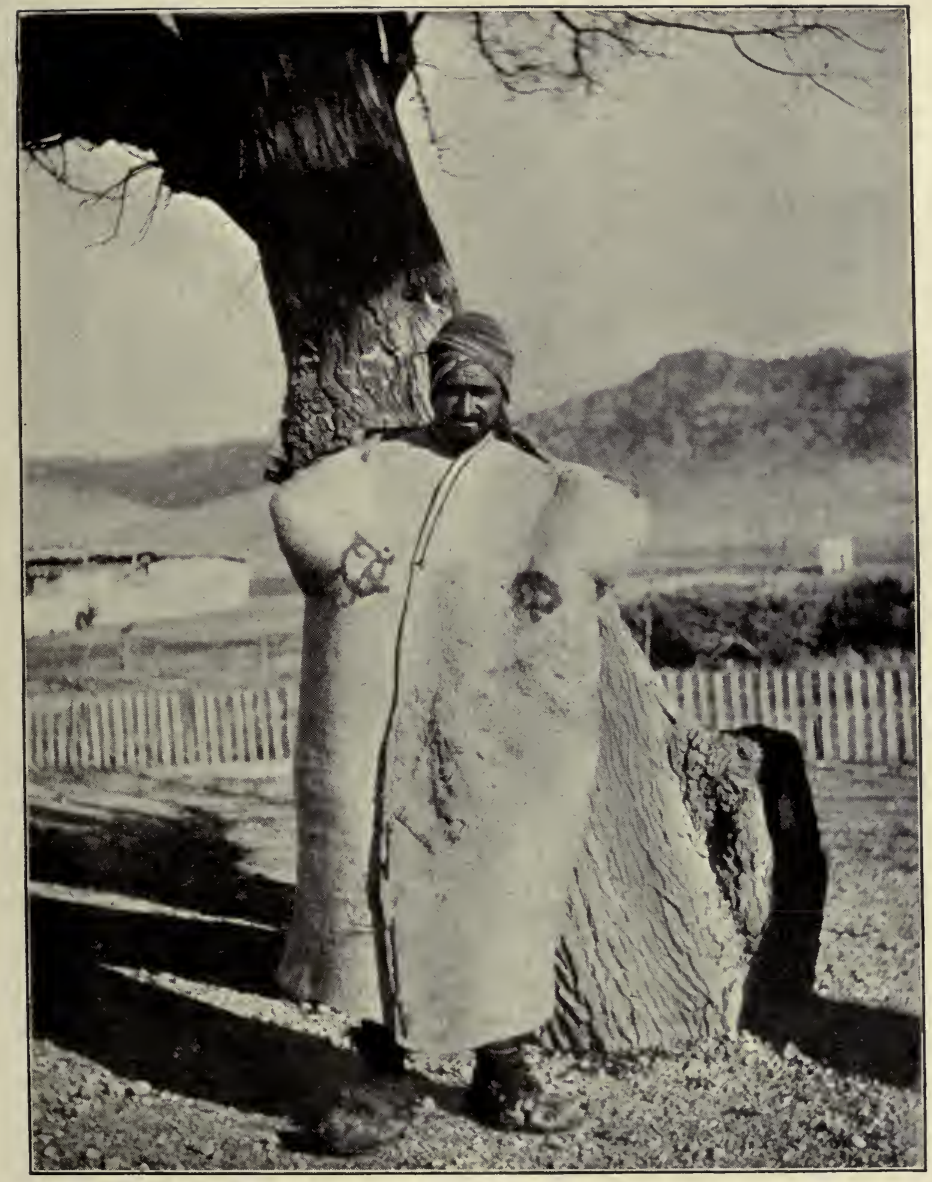

YURUK SHEPIIERD IN WINTER DRESS

Note the armless felt coat

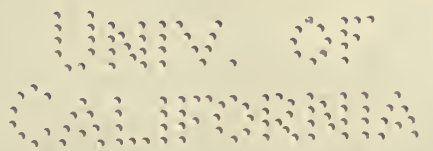



a flock of large birds which I felt sure were great bustards; and on making inquiries I found that these birds were common in this district, and were to be seen from the station almost any day in the early morning. Sure enough, on getting up soon after six the next morning and taking a look round, I saw a flock of about twenty of these magnificent fowl standing in the bare open plain not more than five hundred yards from the station buildings, whilst others were dotted about at greater distances. To attempt a stalk was manifestly impossible; but I thought that I might get within shot by disguising myself as a Turkish peasant, so, borrowing one of the great stiff square and armless felt coats worn by the Yuruk shepherds, I walked slowly out of the station, taking a line that would bring me within two hundred yards of the bustards. They evidently observed me at once, and one and all stood motionless with their heads up. Not knowing exactly how wild they were, I thought that if I could get within two hundred yards of them I would not attempt to approach any nearer, but would sit down and take a steady shot at the biggest bird. I picked out a monster, and, keeping my eye fixed upon him as I advanced, at length thought I had better sit down quickly and try a shot. Up to this moment the bustards had stood like statues; but the instant I halted, and before I had even made an attempt at sitting down, the whole flock rose from the ground like one bird, and flew off without the preliminary flapping 
along the ground, which, from my knowledge of the great-crested bustard (Eupodotis cristata) of South Africa, I should have expected from his somewhat less bulky though nearly allied congener of Europe. After this, although there were many more bustards dotted about the plain, I found that they would not allow me to approach within four hundred yards of them. After trying two very long shots with no result, I returned to the station, and told Pabli to get breakfast ready by the time Dr. C. arrived, so that we might lose as little time as possible in making a start for the hill.

The train arrived in due course; the Doctor and I made a substantial breakfast, and then, accompanied by one old Turk, made a start for the broken cliffs and wooded corries of the Maimun Dagh, leaving Pabli and Manoli to pack up the tents and baggage, and get them conveyed to our camping-ground.

Before proceeding further, I ought to say something as to the nature of the country in which I was about to hunt; but I will content myself with a few sentences on this head, referring my readers for a fuller description of the ground to one of the best books on big game-shooting that I have ever read; namely, "Short Stalks," by that experienced sportsman and entertaining writer, Mr. E. N. Buxton. In the chapter on the "Father of all the Goats," will be found a full description of the Maimun Dagh. Suffice it to say that one face of this mountain is very broken and in many places precipitous, cut into numberless ravines and 
corries, the sides of which are everywhere clothed with forests of juniper, except, of course, on bare cliffs. This broken face of the mountain has a length of seven or eight miles, and rises to a height of about fifteen hundred feet above the plain. At its foot runs the railway line for its whole length, skirting at the same time the large salt pan I have before spoken of. It is this broken rugged mountain face, with its numerous precipitous cliffs and fantastic buttresses of bare rock, which has earned the appellation of the "Monkey Mountain," the idea being apparently that it would require the activity and climbing powers of a monkey to get about on it comfortably. Given, however, a pair of india-rubber-soled shoes and a fairly good head, the Maimun Dagh presents but little difficulty or danger to the hunter of wild goats, the pursuit of which animals is very much easier in every way there than upon the precipitous limestone mountains on the south coast of Asia Minor, which in places come sheer down into the sea, and many of which can only be ascended with considerable difficulty. But let me return to the Maimun Dagh.

As snow was lying on the top of the mountain, the Doctor thought it would be useless looking for the wild goats on the highest ridges, so we searched for them in the ravines from five hundred to one thousand feet above the plain. It was a clear, frosty morning as we ascended the lower slopes of the mountain on February 4, and, although the sun was 
shining brightly, the air felt fresh and invigorating throughout the day. We kept along the side of the mountain, climbing in and out of numerous ravines and corries, and always examining the ground before us as carefully as possible from every coign of vantage. We had proceeded in this manner for about four hours without seeing anything, when, after peering over the top of a ridge for some time, and carefully examining the ground before us, without having been able to make out anything, we rose to our feet to move forwards. We immediately disturbed a little flock of eight nanny-goats and kids, which had been lying all the time - but quite invisible to us amongst some bushes at the base of a cliff not more than two hundred yards away from us. As soon as they moved we saw them, of course, but as they crept away amongst the bushes, only revealing to view an occasional patch of brown, it was impossible to tell whether or no there was a ram amongst them. When they had gained a distance of some three hundred yards, however, they sprang up a wall of rock, and thinking, I suppose, that they were out of range, stood looking back towards the ridge where they had seen us, and where we were still sitting. As one after another the sure-footed little animals sprang up the bare face of the rock, to which their reddish-brown coats assimilated almost exactly in colour, I had a good look at them with my field-glasses, and saw that there was not even a small ram amongst them. Had there 
been, I should have tried a shot; but I had no wish to shoot a nanny, whose head would have been a poor trophy, and who at this season of the year would have been in young. The old rams, though not in high condition, are at this season at their best, from a picturesque point of view, and in their whitish coats, with broad black shoulder-stripe, long black beard, and beautifully curved horns sweeping back almost to their haunches (and attaining to a length sometimes of nearly four feet), they are, to my mind, one of the very handsomest prizes to be won by a sportsman in any part of the world. There is of course no close season for the wild goats, or for any other wild animal in Asia Minor; and as they have been hunted and harried the whole year round from prehistoric times up to the present day, they have developed a perfectly abnormal acuteness of all their senses, which renders it by no means an easy matter to bring one to bag by fair hunting.

Shortly after seeing the little flock of nanny-goats, we were sitting amongst some juniper-trees at the foot of a cliff, examining the broken ground below us, when suddenly a kid, followed by its dam, came walking along a shelf of rock immediately in front of us; and, as we were well concealed behind the stems of the juniper-trees, and the wind was favourable, the little kid came actually to within twenty yards of where we were sitting, and I noticed distinctly its broad forehead and yellowish eyes. As I had no intention of shoot- 
ing either the kid or the nanny, I made no motion to take up my rifle, which was lying beside me; but the Doctor could not resist the temptation to try for a shot - pour la viande, as he explained - and so stretched out his arm towards his gun. But the movement was seen by both mother and kid, who, immediately suspecting that they had got into bad company, were off the rock, round a juniper-tree, and out of sight before their would-be slayer had time to say "Sacristi," or make any other philosophical reflection that would occur to a disappointed sportsman at such a moment.

After this, it being past midday, we wended our way to a ravine, where the old Turk said we would find a little water, and there we made a frugal lunch of dried figs and bread. Whilst enjoying our meal, we saw a party of about a dozen natives of the country passing along the top of a ridge of rocks above us, all armed with long guns. This was a hunting party, the Doctor informed me, that had been on the mountain for some days, numbering altogether fifteen guns and a lot of beaters. Although they had had a certain number of goats driven past them, and had fired a good number of shots at them, they had not bagged a single animal, though they had wounded and lost a young ram. This animal, our old Turk told us, on being followed up had made right down to the foot of the mountain, where it was seen by a peasant passing with a bullock cart. He, on going up to it, found it 


\section{SPORT AND TRAVEL}

too weak to move, and so promptly despatched it, and carried it home on his cart, chuckling greatly to himself as he saw the sportsmen presently coming down the mountain, following slowly and carefully on the blood spoor of the wounded animal. Naturally, when they reached the spot where the peasant had killed and lifted it from the ground, the blood tracks suddenly ceased; nor, although they made casts all round could they ever pick up the spoor again. The man had left no footmarks on the hard stony ground, and they never dreamed that their goat had been picked up a few hundred yards in front of them, and was at that moment reposing peacefully on the bullock cart that was being driven slowly along over the plain below them. Allah had not been kind to them; but, on the other hand, he had been very good to the driver of the cart.

Our lunch finished, we again went forwards, and kept moving till late in the afternoon; but though we worked through some very promising-looking ground, we saw no more goats, and when shortly after dusk we reached our camp, which had been pitched at the foot of the mountain, at a spot well known to the Doctor, close to a spring of water, we were quite ready for the substantial dinner which Pabli had got ready for us.

We were up betimes the next morning, and in the early dawn climbed the steep face of the mountain to a height of about one thousand feet above our camp, 
on our way disturbing four nanny-goats, a long distance from us, on the opposite side of a broad ravine. Although they must have been six or seven hundred yards off when they first observed us, they did not seem to trust us even at that distance, but commenced to climb rapidly up some very steep rocky ground above them, and at last disappeared over the top of one of the fantastic and picturesque buttresses of rock which form such a striking feature in the landscapes of the Maimun Dagh. We now kept along the side of the mountain in the same manner as we had done the preceding day, but over entirely fresh ground, as on Monday we had only hunted that portion of the mountain lying between Chardak and our camp, whilst we were now working the ground beyond. Our plan was to keep along the hillside for three or four miles at an elevation of about one thousand feet, and then, after ascending to the top, to work back again through the highest corries.

The Maimun Dagh is, I may say, so wonderfully broken up by innumerable ravines and corries that it takes fully half a day to work quietly and cautiously along three or four miles of its rugged face. I think it must have been about eleven o'clock that, climbing out of a steep-sided ravine, we reached a ridge covered with large pine-trees, and peered cautiously first over a bare wall of rock above us, and then into the thickly wooded ravine below. For some minutes we lay still, and examined the ground above and below us very 
carefully, but saw nothing. Then the Doctor stood up, and immediately said excitedly, "Regardez; les bouquetins; les grands;" and I too saw them as they moved. Three splendid old rams sprang one after another from behind some bushes down two or three yards of open rock, and were immediately hidden from view in the scrub below. Alas! once more these wary animals had been lying, as they always do, in such a position that they could not be seen, whilst they were sure of seeing, smelling, or hearing any enemy that approached. For one instant of time I saw them, as I have said above, spring one after another down a bare piece of rock dividing two patches of scrubby bush, at a distance of not more than one hundred and fifty yards; but the glimpse I got of them, momentary as it had been, was sufficient to reveal to me that at last $I$ had seen what I had toiled and searched for in vain in the previous autumn, three patriarchal specimens of Capra agagrus. I had marked in each of them successively the long beard and black shoulder-stripe, and, above all, the great sweeping horns that looked almost too large and heavy for the heads that bore them.

A very quick shot might have snapped at one or other of them during the moment of time that they were exposed to view; but the goats were a long way too quick for me. As they were going downhill when we saw them, the Doctor ran along the ridge, hoping to get a sight of them as they crossed an open 
space farther down; but I remained where I was with the old Turk, sitting quite still, and hoping that they might climb up the bed of the ravine and make for the rocks above us. This is exactly what they did; for presently, just as I had moved my eyes from the hillside above me, and was again searching the wooded ravine below, my companion touched me and pointed silently upwards, and following his eyes I saw a sight which will long live in my memory. The three old billies were standing on a ledge which ran across the face of the bare cliff; they did not seem much alarmed, and were moving very leisurely along the ledge. My impression is that when they first moved and sprang down the rock, they had neither seen nor winded us, but had only heard the Doctor move a few small stones as he stood up. They had then probably made their way amongst the bushes to the bottom of the ravine and stood listening, and, on hearing the Doctor pelting along the top of the ridge, had turned back. After creeping cautiously up the scrubby hollow and hearing nothing more, imagining that the danger was past, they had climbed on to the bare rock to take a look round. They were, I think, about two hundred and fifty yards off, but being much lighter in colour than the rock which formed a background to them, they showed up well, and offered a very good mark.

Now for my first shot at game with the little .303 rifle. I had carefully sighted it for one hundred 
yards at Mr. Holland's shooting-ground, and had found that by taking the foresight very full, I could shoot with it up to two hundred and fifty yards. I was already sitting down, but not facing quite the right way, so turning noiselessly on my axis I placed an elbow on each knee, South African fashion, and taking the ivory foresight very full on the shoulder of the foremost goat (as I could not see that there was any choice of horns amongst the three), pulled the trigger. He made a plunge forward, and rushing down a steep face of rock, was out of sight in an instant. I could not tell whether I had hit him or not; but I felt sure that if I had not, I must have gone very close to him, - a very poor consolation in a case of this sort. The report of my small rifle being much fainter and farther off than the goats on the Maimun Dagh were accustomed to hear, the two remaining old billies evidently did not know quite what to make of it, nor did they realise exactly the nature of the danger that threatened them; for turning round, they sprang a few feet along the ledge on which they were standing, and then stood close to one another, half hidden by a small bush. Hastily reloading, I lost no time about firing at the one I could see best; but for this shot I pushed up the second sight, as I thought the distance a bit too far for the first. In doing this I made a mistake. At any rate, I missed my mark, and the goats were instantly round a rock and out of sight. The old Turk 
made a motion with his hands, indicating that the bullet had just grazed over the goat's back; but I doubted his knowing anything about it, and was at the time rather inclined to the view that both shots had been hits. I did not move immediately, as I wished to wait for the Doctor's return before searching for blood spoor; but in less than a minute after I had fired the last shot, one of the two goats that had just disappeared again showed himself high up on a ledge of the cliff far above us. He looked very white, and carried a beautifully curved pair of horns; but he was a very long way off, - at least three hundred and fifty yards, I should think. However, I thought there could be no harm in trying a shot at him; so, pushing up the third sight, and holding, I think, steadily on him, I fired, and once more was informed by the Turk at my side that in his opinion I had again fired a little too high. As before, the intelligence was conveyed by expressive signs.

As soon as the Doctor came up, we made our way to the foot of the cliff, and the Turk and I with some difficulty got up to the ledge where the goats were standing when I first fired. The wash-down from the rocks above had covered this ledge in places with a thin layer of sand; and where the foremost goat had stood when I fired at him, the tracks of his fore and hind feet were plainly visible; there, too, on the wall of rock behind was the splash of the bullet plain enough, and seemingly exactly at 
the right height above the hoof-marks to have passed through the animal's body. As I had fired from below, the bullet was certainly not high enough above the ledge to have passed over the goat's back, and, from its position in reference to the foot-marks, must have either gone through him, or just grazed beneath his chest behind the fore legs. The second bullet had been a little too high, and the third too low, - both being registered plainly enough, like the first, on the wall of rock. It was not only the position of the bullet-mark, but the way the old goat first fired at came rushing down the rock after the shot, that made me think he was hit; and to this day I cannot reconcile myself to the idea that I missed him. ${ }^{1}$ However, search as we would, we could find no trace of blood, and at last had to give it up as a bad job. I was bitterly disappointed, and needed all the comfort the little Doctor could give, in the way of assurances that we should see more old goats, to keep up my spirits.

Had I only been a good shot, I thought, I might have secured three magnificent trophies at one glorious stroke; but as it was, I had bungled a chance that might never come again. Well, I had learned, at any rate, that there were some magnificent old billy-goats on the hill, and I determined to persevere in their pursuit, and do my best to secure a good head; so after finally abandoning the search for

1 This goat, a six-years-old ram, was found dead by a Turkish hunter some time after my visit, and his horns were shown to Mr. H. IV. 
blood spoor, we kept on our way along the side of the mountain, until we at length reached a point beyond which the Doctor said it was useless to look for goats, as we had got to the limit of their feeding-ground. We then climbed to the top of the mountain, and worked back among the highest corries until we reached a point directly above our camp. We had seen no more goats, and as by this time the sun was down, it behoved us to make for camp, which we did not reach till the shades of evening were closing in.

I had expected two friends from Smyrna to join me that day; but as they had not arrived when we reached camp, I came to the conclusion that they had been prevented from coming. Shortly afterwards, however, we saw a figure approaching in the dusk, closely followed by a small donkey carrying a load, with a second figure in close attendance upon it; and in another minute I was shaking hands with my friend Mr. J., an Englishman long resident in Asia Minor, thoroughly conversant with the ways and languages of the country (Greek and Turkish), and a very cheery companion. My want of success had by no means spoiled my appetite; so whilst we were discussing a savoury meal, I recounted to my companion all that had befallen me during the two previous days, and the great success I might have had if fortune had but favoured me, for, after all, there is a little luck in judging distances correctly, when 
shooting in a wild country at ranges beyond two hundred yards.

After dinner we discussed the programme for the morrow, and it was agreed that the Doctor and I were to hunt back towards Chardak, taking a line about midivay up the mountain, whilst J. and Moussa the Turk would take a parallel line, but at a higher level. In this way we hoped that if one or other of us came across goats, the disturbed animals, in their flight up or down the mountain, might come within range of the other rifle.

On Wednesday morning we again made an early start, and all climbed the first thousand feet above our camp together; then, after giving $\mathrm{J}$. and the Turk time to ascend some five hundred feet higher, the Doctor and I kept along the mountain-side, working over the same ground as we had traversed on the previous Monday, only going in an opposite direction. After a couple of hours' walking and climbing, I made out a goat standing in the shade of a small bush, near the head of a ravine, and, looking at him through the glasses, saw that he was a fair ram, though his horns were nothing like those of the three I had seen on the preceding day. He was a long way off, well over three hundred yards, I judged; but as the wind was very bad, and I saw no chance of getting any nearer to him, I determined to take the off-chance of hitting him with a long shot. Getting into a steady position and putting up the third sight, I had my shot, and, as was to be ex- 
pected, did not hit the goat, which, disturbed by the report, or the whizz of the bullet, trotted out from its shelter for a few yards, and then bounded away through the bushes.

It must have been about midday when we reached a broad, deep ravine, divided at its head into several rocky corries, which are a favourite haunt, the Doctor informed me, of wild goats, so we advanced very cautiously and kept a sharp look-out. We had just reached a point amongst some juniper-trees and bushes which commanded a good view over a series of rock terraces, sparsely sprinkled with trees and bushes, when five goats showed themselves on one of the highest ledges of rock, at a distance of about four hundred yards from where we were sitting. They had evidently been disturbed, probably by J. and the Turk, and were coming down the mountain face pretty quickly, in a line one behind the other, and at one time seemed to be heading straight for where we were sitting, but unfortunately turned off again. They were all big rams, looking very white against the sombre background of grey rocks and dark-foliaged junipertrees, and all seemed to carry good heads; but the old billy that brought up the rear far excelled his companions in this respect, and bore a pair of horns the like of which has, I fancy, seldom been seen and never obtained by a British sportsman. As I looked at him with the glasses, I marked with what a symmetrical sweep the long horns curved backwards, and on one 
occasion when he stood for a moment on a rock and turned his head towards us, I could see that the points of his horns diverged from one another, the ends being plainly visible on either side of the thick part of the horn that rose immediately above the head. However, I had not much time for observation, as the goats were advancing rapidly but cautiously, halting at every few yards, and at such times being unusually sheltered by bushes.

Soon they reached the brink of a little corrie, and the foremost animal seemed undecided whether to enter it, or keep along its edge. Had he decided upon the latter step, he would probably have passed with his companions within one hundred yards of our ambush, but unfortunately he was not so accommodating; and as soon as he commenced to descend the corrie I saw that I should have to shoot quickly or not at all, so getting into position, I prepared for a careful shot at the magnificent old ram that brought up the rear of the party. The distance was about two hundred yards, and as he stood for an instant, broadside on close to the stem of a large fir-tree, I fired a very steady shot at him, taking the sight a little full. At the shot he dashed forward, and in an instant was out of sight amongst the rocks and bushes at the bottom of the corrie. I had felt sure I had hit him, not only because I had had a good sight of him at the moment I pulled the trigger, but also because of the way he had dashed forwards; and so, without 
waiting an instant, I made for the big tree close to which he had been standing when I fired, in order that I might hit off his tracks and look for blood spoor. I was in the bottom of the corrie and advancing rapidly to where the goat was standing before I fired, when glancing to the right, I saw a fine ram standing on a rock in full view and not more than one hundred and fifty yards from me. At the same time I saw the tops of the horns of two or three others just showing above another rock. I lost no time in firing at the one I could see, and it seemed to me that he flinched at the shot before springing off the rock and joining his companions.

Having well marked the rock on which he had been standing, I went on to look for blood on the tracks of the one I had first fired at, and was still searching when the Doctor came up. But not a drop of blood could we find, and I was at last reluctantly forced to believe that I must have taken the sight a little too full or a little too fine, and so either fired over or under him. In this country I may say that if you cannot get blood spoor you cannot follow a wounded or unwounded goat, as he is never very far from rocks and stones, over which he jumps and climbs without the least trace in the way of hoof-marks. I was not at all sure that the animal I had last fired at was the big ram whose horns I had so much admired as he came down the mountain-side, for in the hurried glance I cast on him before firing, I had had no time to no- 
tice anything except that he was a big old goat, very white in colour, with horns of some sort. Perhaps, I thought, I had wounded him with the first shot and caused him to lag behind his companions. With this idea we now went up to the rock on which I had seen him standing, and from there followed the line he had taken till he disappeared behind a boulder of rock. For twenty yards there was no blood, then suddenly the ground before us was so thickly sprinkled with the crimson stain that I knew the wounded animal must have been shot through the lungs and was throwing blood at every step from his mouth and nostrils. That he must be lying dead within one hundred yards of us I felt sure, and so he was; but it took us some little time to find him, nevertheless, for dying, as he must have been, and with the life-blood gushing from his mouth and nostrils at every step, the hardy beast had managed to spring up a wall of rock which I should have thought that even an unwounded goat would have hesitated to attempt. As there appeared to be no necessity for this step, we were at fault for some time, and could not imagine why the heavy blood spoor had come to such a sudden end. At last we saw a splash of blood some eight feet up the wall of rock, and realised what had happened. It took me some time to get to the top of this mass of rock by a circuitous route, leaving the Doctor to mark the spot. Once on the top of the rocks directly above him, I again took up the blood spoor, and advancing across the top to the other side 
and looking down, I saw a fine old goat lying dead on a flat stone about twenty feet below me. It took us some time to get to him, as he was inaccessible from above, and I had first to rejoin the Doctor, and we then had to get back to the bottom of the corrie and climb up to the dead goat from below.

He was a fine animal, nearly white in general ground-colour, though darker (a light sandy yellow) on the lower part of the sides and under the belly than on the back. He had a broad black shoulderstripe and a black line running from behind his horns all down his neck and back. His ears were small, as in all the goat tribe, but his head was set off by a flowing black beard, whilst his tail and the lower parts of his legs were also black down the front face. Immediately I looked at his horns I saw he was not the ram I had first fired at, and was much disappointed. Still he carried a pretty head measuring twenty-eight inches, but his horns lacked the beautiful sweeping curve of the grand pair I had seen through the glasses, and which I knew must have been exceptionally fine.

Just after we had got our prize down to a piece of level ground suitable for skinning and cutting it up, we were joined by J. and the Turk, who had seen us from the rocks above. On examining the dead goat, we found that my bullet had entered on the left side just behind the ribs, and traversing the body obliquely forwards, had passed out at the point of the shoulder. 


\section{SPORT AND TRAVEL}

Inside, it had cut a large hole through the liver and lungs, just missing the heart, and wherever it had passed through or near muscle it had turned the meat black. Neither the hole by which the bullet had entered nor the one by which it had made its exit was very small, and, indeed, the wound was altogether quite as severe as if it had been made by an expanding $.450-$-bore projectile of the best kind. Yet, strange to say, not one single drop of blood had exuded from either of the wounds, and had the bullet missed the lungs after passing through the liver, there would have been no blood spoor whatever, although the wound would undoubtedly soon have proved fatal.

On noticing the entire absence of blood from the bullet-wounds in the carcass of the dead goat, I could not but think I had hit the ram with the big horns, as I had had a very steady shot at him, and the distance was not very great. Still, there being no blood spoor, I could not feel at all sure about it, and could only hope that if he had been really hit, but a little too far back to be immediately fatal, the vultures might still guide me to his carcass in the course of a day or two. As a matter of fact, I did not find him, but I have the strongest reason to believe that his head is now in my possession. I recovered it in this way. On the afternoon of Tuesday, February i2, Mr. J: and.I returned to Chardak station, and Mr. J. there heard that a Turk had a few days previously found a large goat dead in the mountain, so we sent for the man, and on 
his arrival he told Mr. J. that on the previous Thursday - the day after I had fired at the big ram - he had been out on the mountain and had seen a very large goat slip and fall from a cliff into a tree, in which he had hung suspended by his horns until the narrator of this tale went up and despatched him. I thought this an impossible story, as a goat never slips or falls off a rock, except when at the last gasp, but asked J. to offer the man something for the head, which was brought down the next morning. Directly I saw the long and beautifully curved horns, and marked how the points turned outwards, I felt sure they belonged to the grand old billy I had fired at on the day I killed the smaller animal, and a few questions soon involved the Turk in a labyrinth of lies. At last he admitted he had found it dead, but said it had been killed by falling off a cliff. However, we could prove nothing, and so bought the head from him for a few shillings. It was, of course, quite fresh, with all the flesh and skin on; but the lower jaw having been cut off to get at the tongue, and the skin cut off just behind the horns, the head was destroyed for mounting. I think there can be very little doubt as to this head being that of the animal I had fired at, wounded, and lost a few days before, as the Turk's story as to how he got it was self-evidently a lying one, though he admitted finding it on the day after I had fired at an animal with very large horns of a similar shape and in the same part of the mountain 
in which I was hunting. Why he lied about it, Mr. J. said was because had he confessed that its death was due to a bullet-wound, which could only have been mine, he feared that I might have put in a claim to the skin, whilst had he brought the goat down to our camp as he found it, he might only have been rewarded by a couple of dollars, whereas the skin was worth a Turkish pound (about I8s. or I9s.), as the skin of a full-grown wild-goat ram, with its strong smell and black harness-like markings on the light-coloured ground, is much prized by the Turks in Asia Minor as a "praying-rug."

As the Turk only brought the head to the railway station on the Wednesday morning just before the train was leaving for Smyrna, I was unable to buy the skin of the disputed goat, but have commissioned the Doctor to try to get it for me. The horns are magnificent, beautifully curved, and perfectly symmetrical, with the ends curling outwards. The point of one is slightly broken, the length of the perfect horn being forty-six and a half inches over the curve, and just under nine inches in circumference at the base. Although I cannot absolutely prove it, I am sure in my own mind that this magnificent wild goat was the victim of my rifle, and my only regret is that, the head skin having been cut up, I could not get his head properly mounted.

On the following day (Thursday, February 7) I spent the morning in camp, skinning and preserving 
the head of the wild goat which I had killed the previous day, intending to take a turn on the mountain in the afternoon, although in the event, as the weather was very unpropitious and looked as if heavy rain was going to fall, I did not go out at all, but spent my time in attending to the drying of the goat's head skin, which I had to be constantly putting inside the tent during the frequent showers of rain. Towards sundown a Turkish hunter, whom the Doctor had sent for, came to our camp, a well-knit, active-looking man of medium height, keen dark eyes, and the handsome rather aquiline sort of features, which is a common type amongst the Turks in the interior of Asia Minor. I forget his name, but I found him a very good fellow, well acquainted with the mountain upon which we were hunting, and the habits of the wild goats that lived upon it. He of course exaggerated their numbers and size, but seemed pretty confident that he would be able to get me a shot at a fine ram in the course of a day or two, so it was arranged that on the following morning he was to accompany me to that part of the mountain where I had seen and fired at the three big rams on the previous Tuesday, Mr. J. and the Doctor at the same time hunting in the direction of Chardak.

Although some heavy showers fell during the night, Friday morning broke bright and clear, and after an early cup of coffee I once more climbed the rocky face of the Maimun Dagh in company with my new guide, 
whom I will call Mustapha. About an hour after leaving camp we came upon a small herd of seven or eight goats, standing in rather a favourable position for a shot, on a bare steep slope of rock. When we saw them we were a little above them and about three hundred yards distant, and might, I think, have approached to a point on the top of the cliff within one hundred and fifty yards of them; but as they were all ewes and kids, without even a young ram amongst them, I did not attempt to stalk them, and after watching them through my glass until they disappeared one after another behind a projecting buttress of rock, bade my guide by signs to proceed in search of nobler game. As the Doctor had carefully explained to him that I did not want to shoot ewes, but was very anxious to bag a big old ram, Mustapha was not at all surprised at my leaving the little flock of kids and nannies alone; but after making signs which I took to mean that there were some big billies on the mountain with great curved horns, proceeded silently and cautiously on his way onwards and upwards.

It was nearly midday when we reached a projecting buttress of rock at the head of one of the highest corries on the Maimun Dagh, and leaving Mustapha crouching close to a rock some yards behind me, I advanced to the very edge of the cliff, and lying flat on my stomach searched the ravines below me with the glasses. But in vain, for, good as the ground looked, no sign of life was to be seen. I hardly 
expected to see goats on the move at this time of day, but as it was winter and quite cold in the shade, I thought they might reasonably be expected to lie out and sun themselves on the bare rocks. After having carefully scanned the broken ground below, I turned the glasses to some buttresses of rock some distance to our left, similar to the one upon which my guide and I were seated, and on about the same level; and the first thing I saw was a Turkish peasant with a long gun squatted on a rock at the edge of a precipitous cliff, evidently on the look-out for wild goats. Soon I made out another figure, also armed with a longbarrelled gun, seated on the edge of the cliff about one hundred yards beyond the first, and realised that a party of villagers were on the same quest as myself, the guns being posted in advantageous positions, whilst a party of beaters were probably endeavouring to drive game towards them. As a hunt was in progress, Mustapha conveyed to me by signs his opinion that we had better remain where we were for a time, and see if fortune would not send something our way; so seating myself on a rock close to the edge of the cliff and keeping a keen look-out all around me, I remained perfectly quiet.

Placed as I was, on the edge of a cliff some thirteen or fourteen hundred feet above the plain below, I commanded a magnificent panoramic view over a vast extent of country. At the foot of the Maimun Dagh lay the shallow salt lake of which I have already 
spoken, filling the whole valley (some three or four miles in width) to the foot of the Zuut Dagh, whose precipitous limestone cliffs and snow-sprinkled peaks were sharply reflected in its clear but briny waters. Beyond the Zuut Dagh, and on either side of it, and, indeed, wherever one could obtain a view uninterrupted by the wooded sides of the Maimun Dagh, lay range beyond range of snow-covered mountains, till in the far distance one's field of vision was bounded by the dead white masses of winter snow, which cover to an unknown depth the great domes and peaks of the White Mountains beyond the Turkish town of El Maly. Presently I noticed some woodcutters with several pack donkeys ascending the hillside far below, and when at length they reached a point some five hundred feet beneath me, I saw an eagle, disturbed by their approach, rise from a cluster of tall pine-trees, which, after circling round for a short time, I marked down on to an enormous nest - the accumulation of many years, probably - built on the decayed top of a large fir-tree. In a short time the eagle again flew up, and then, looking almost vertically down into the nest with the glasses, I distinctly saw something white, which I knew were eggs, or at least one egg, and this I determined to secure for my collection before leaving the Maimun Dagh.

But all this time we had heard no sound which might portend the advent of beaters, and I was just about to propose to Mustapha that we should make a 
move, as I had come to the conclusion - which I think was correct - that the two Turkish sportsmen were simply hunting, like ourselves, without beaters, when we both heard some stones move on the hillside above us, which was thickly covered with brushwood. The next instant I saw that Mustapha, from whom I was some yards distant, had seen something, and on creeping cautiously to his side and looking eagerly towards where he was pointing, I at once made out what I knew was a portion of a wild goat standing amongst the bushes some one hundred and fifty yards away; but what part of it, or how the animal was heading, was more than I could determine. Nor had I much time for investigation, for the next moment a big old billy-goat bounded forwards through the scrub, closely followed by a second. As they passed through the brushwood I only got momentary glimpses of them, but soon they emerged upon an open sheet of rock; and as they rushed across it, broadside on, and at a distance of about two hundred yards, I had a very good view of them. I did not fire, for the reason that I thought they were going to cross a deep gully just in front of them, and judged that, even if they did not stand after crossing it, I should have had a better chance of hitting one as he climbed up the farther side, even though the range would have been somewhat longer, than I should have done had I fired when they were bounding down the rocky slope at their utmost speed. But, the first chance missed, they 
never gave me another, as instead of crossing the gully they disappeared over its edge, and then, running down its bottom, did not show themselves again till they had reached a point far below us. They then turned back towards our camp along the lower slopes of the mountain. These two goats had, I suppose, been lying amongst the bushes on the mountain-side above us, and a gust of wind blowing up from the plain below must have given them warning of our proximity; but at first they had evidently been only very slightly alarmed, and could hardly have realised where exactly the danger lay, and had the wind but refrained from blowing for another few moments, they would probably have shown themselves as they moved slowly through the bushes, and given me a very fair chance at one or other of them. As it was, they had only given me a very difficult chance, and, such as it was, I had failed to take advantage of it. Mustapha now gave me to understand that they would not run very far, but would make their way back towards our camp along the lower slopes of the mountain, and that by following cautiously on the line they had taken, and examining the country in front of us from every high bit of ground, we might yet come up with them again before the day was over.

On our way down to where we had the last glimpse of the goats, we passed close to the pine-trees on which the eagle's nest had been built, and put the bird off it again, so that, early as it was in the season 
(February 8), I felt sure it must contain an egg or eggs. The species of the bird I could not determine, as it seemed to me smaller than either the golden or the sea eagle, though the tail seemed to have a good deal of white in it. ${ }^{1}$ However, there was no time just then to do anything more than mark the position of the nest in reference to the surrounding country, with a view to revisiting it and taking the eggs, and perhaps shooting the eagle to make sure of identifying them; so after calling Mustapha's attention to the nest, and trying to make him understand that I wanted to come back to it and take the eggs, we pushed on after the goats. We soon hit off their tracks on a piece of soft ground, and though we soon lost them on some rocks, we kept on, on about the line they had been taking. We had been travelling along the hillside for some two hours or more, climbing in and out of the ravines of greater or lesser extent, subdivided into numberless small corries, when, on peering over a pile of rocks, we commanded a view over a much broader ravine than usual. Some two hundred yards distant, and rather below us, a large buttress of rock running out from the hill above divided this ravine into two unequal portions, the larger being beyond it. Standing motionless on a ledge near the top of this buttress of rock, we saw a small nanny-goat. I do not think it saw us, as we were peering very cautiously over the edge of the

1 This bird proved to be a Short-Toed Eagle (Circaëtus gallicus). 


\section{SPORTAND TRAVEL}

boulder; but almost immediately after we had observed it, it moved on along the ledge and disappeared round the shoulder of the buttress of rocks, and as it moved I saw that it was walking very lame. We were stili examining the ground some few minutes later, when suddenly the two magnificent old billy-goats we were looking for stepped out on to a ledge of rocks in full view some hundred yards beyond the foot of the buttress by which they had been previously hidden. Following closely behind them came the lame nanny; and I have no doubt that, had we reached our station a couple of minutes earlier, we should have seen the two big goats on the near side of the buttress where we had first seen her.

The two big goats were, I think, certainly the same that we had disturbed earlier in the day, and had since been following, and they must have picked up the lame nanny as they went along. Had I just caught them on the buttress, I should have had a nice shot at about two hundred yards; but they were now too far off for me to feel at all sure of hitting, had I tried a shot, so I resolved to wait and let them get out of the ravine they were in, in the hope of being able to get nearer to them in the next. They were moving very slowly along, one behind the other, continually halting and standing motionless for some considerable time. Sometimes the nanny-goat was behind and sometimes she led the two old billies, that also continually passed and repassed each other. 
Having a very strong pair of field-glasses, I had a most excellent opportunity of watching the movements of these shy and wary animals, and was rather chagrined to see that the biggest of the two rams had only one horn. When he stood broadside on it was impossible to detect the loss, but when he turned his head it became very noticeable. The single horn was magnificent, and curled over the shoulder in a fine bold sweep. The smaller ram was also a splendid animal, with a perfectly symmetrical pair of great curving horns, each of which was, however, I should judge, some inches shorter than the single horn of the larger animal. It has been my fortune to look upon many beautiful forms of animal life in their native haunts, but I do not think that I was ever more impressed by the picturesque beauty of any wild animal than I was with the appearance of these two grand old goats, as they stood motionless from time to time, their whitish coats and broad black shoulder-stripes showing out conspicuously against the reddish background of rock and stone, and setting off to the best advantage the contours of their sturdy though symmetrical forms, whilst their great curved horns and long flowing black beards gave them a dignity of appearance not often to be found in so comparatively small an animal. Comparisons being odious, I will not compare them with any other wild game; but I think that the head of a wild goat, with horns well over forty inches in length and nine inches 
in circumference at the base, is a trophy that any sportsman might be proud to secure, the more especially as the bearer of such a head is, according to my experience, a most shy and wary animal, requiring a good deal of patience, perseverance, and hard work to bring to bag by fair hunting.

At last the two old goats, still closely followed by the nanny, slowly ascended the ridge of rocks on the further side of the valley, and disappeared one after another from view. The great one-horned ram led, closely followed by his somewhat smaller companion, the nanny bringing up the rear. Each in turn paused for a moment on the sky-line, and though some six or seven hundred yards distant, the great curved horns of the two old rams were still plainly visible to the naked eye, as each in turn stood for the moment turning his head from side to side. Now for it! and immediately the little nanny had disappeared, the active mountaineer at my side rose to his feet and scrambled down the rocks below us, closely followed by myself, for I knew, from the very slow pace at which the goats were travelling, that if we lost no time in crossing the valley before us I might get a shot at them before they reached the bottom of the next ravine. How long it took us to reach the cluster of rocks over which we had last seen the goats disappear, I do not know, but I think we descended to the bottom of the valley and reascended the farther side in very fair time. As the goats were going along the mountain against 
the wind, we were on the right side of them in that respect, and I wanted to climb up the rocks by the same track they had taken, in the hope of getting a shot at them from the point where they had last been visible on the sky-line.

I believe that this would have been the better plan; but as Mustapha wished to approach them from below, by working round the base of the rocks they had crossed, I let him have his way. As we approached the point from which we hoped to command a view of the ground beyond the rocks over which the goats had disappeared, Mustapha dropped on his knees, and, taking off his cap, or fez, crept cautiously forward, I following closely behind him in the same position. Suddenly, after peering over a rock, he drew back, and crouching down made signs to me to come forward. I did so, but on looking over the rock saw nothing. Before me lay a chaos of huge boulders cut into sections by deep chasms, and my guide gave me to understand that he had seen the horns of one of the goats just as he was disappearing into one of them. He now signed to me to keep a good look-out whilst he went back to get his cap, but after surveying the ground, and noting the position of a deep cleft in the rocks in which I felt sure the goats were for the moment hidden, I thought I could get into a better position by advancing along a ledge dividing two great masses of rock just in front of me. Along this ledge I had to advance standing, keeping a sharp look-out on the crevasse in front of me. 
Suddenly the little lame nanny made her appearance, and climbing nimbly up the steep slope of rock stood in full view on the top, at a distance of seventy or eighty yards from me. In another instant I knew that the rams would follow her, and the thought passed across my mind that I possibly might secure both of them, if I could only get a second cartridge into my single-barrelled rifle without any loss of time. To make absolutely certain of my shot, I thought I would sit down before one of the big goats appeared. O most unhappy thought! for as I did so, forgetful of the narrowness of the ledge and the steepness of the rock below it, I could not retain my position, but commenced slithering down the sloping face of the rock. Even as I did so, up sprang the great one-horned goat into full view, and stood for some moments quite motionless, a magnificent spectacle. In vain, lying almost on my back, but slowly sliding down the rock, I tried to steady myself for a shot, and just as the goat saw me and dashed off, I fired in a most awkward position and missed. The second ram I never saw, and I suppose he must have kept down the bottom of the crevasse on hearing the shot, and emerged out of sight farther down.

Wild with mortification and chagrin, I recovered my equilibrium as quickly as possible, and climbing hurriedly up the rocks, took up a position from which I hoped to be able to retrieve my fortune by a long shot as the goats climbed the farther side of the 
ravine they were now in. This was very deep and comparatively narrow, the lower slopes being covered with bush. Presently the two old goats, now no longer attended by the lame nanny, appeared climbing the farther side of the ravine, and after showing themselves from time to time amongst the trees and bushes, at last climbed on to a wall of rock just opposite to me, and once more stood in full view. They evidently thought they were now safe, as they commenced to cross the cliff very slowly, continually stopping to look back across the valley. The one-horned ram was leading, and with all his faults he was the one I was most anxious to shoot, as he looked such a patriarch. I judged him about three hundred yards distant, probably somewhat more; and so putting up the third sight, and taking a steady aim from a sitting position, I fired, and held my breath and gazed with strained eyes towards the small whitish object moving slowly across the rock. Hurrah! a hit, a most palpable hit! for although no thud brought conviction to my ear that my bullet had sped true, I saw the old goat stagger as if about to fall, and then recovering himself limp slowly forwards; whilst his companion, that had been some yards behind him, on hearing the shot, rushed past him across the rock, and bounding up a grassy slope above, disappeared over the crest of the next rise. The wounded animal limped slowly forwards and upwards, looking every instant as if it was about to fall, and at length disap- 
peared behind a cluster of bushes near the top of the rise, but a little higher up than where its companion had last been visible. As I did not see it pass beyond this patch of scrub, I thought it had lain down there, and fully expected to find it lying dead amongst the bushes.

At this moment Mustapha rejoined me, and I tried to explain to him that I had badly wounded the onehorned goat, and thought it was lying dead amongst the bushes where I had last seen it. He seemed incredulous, and gave me to understand that from where he was, he had seen both of them top the rise; and this afterwards proved to be correct, though the cluster of bushes had hidden the wounded ram from me after he had passed them. We lost no time in descending to the bottom of the ravine and climbing the opposite side, which was very steep, and on nearing the top I made directly for the bushes behind which I had seen the wounded goat disappear, and great indeed was my chagrin when on getting to them there was no dead or dying animal to be seen. I then looked for his tracks, and soon found them, but could not find any blood. Mustapha was now standing on the top of the rise, making signs that the wounded goat had passed over, so I went up to him. Although there was no blood to be seen, I felt sure from the way he had behaved after my shot that the wounded animal was badly hurt, and never doubted for a moment that we should find him either dead or dying. 
I was so hot from the haste I had made to $\operatorname{climb}$ quickly up to where I thought I should find the goat lying dead, that as I got up to Mustapha I took off the heavy corduroy coat I was wearing and threw it on the ground, forgetting for the moment that all the cartridges I had with me were in one of the pockets, or perhaps thinking that I should not be likely to require anything more than the one shot I carried with me in the rifle. The ravine, on the edge of which we now stood, was little more than a narrow gully, rather bushy just below, but steep and rocky on the farther side. Mustapha was some yards below me, for I had remained behind to examine the ground in the hope of finding blood, when I saw him stop suddenly, and, after gazing intently for an instant to his right, come rushing back to me. He seized me by the hand, and pulling me rapidly down to where he had been standing, pointed to some bushes at the foot of a rock some twenty yards to our right. I immediately saw the great curved horn of the wounded goat, but before I could make out anything more of him, he rose to his feet in the shelter of a bush and rushed down the steep slope below him. As he dashed down amongst the rocks and bushes, I fired at him, but could not tell whether or no I had hit him. He had got down to the bottom of the gully with a rush, but it was another matter getting up the steep ascent on the other side. He had not far to climb to reach the top, but as he dragged himself laboriously 
up a steep bit of cliff, I saw that his hind leg was broken. I might have had a couple of shots at him, at least, as he climbed that one hundred feet of rock within easy range, but, alas! I stood with an empty rifle and no cartridges. Mustapha, understanding my frantic signs, rushed back for my coat, but fumbled about and could not find the pocket; and when at last I got hold of one it was just too late, for even as I pushed it into the breech, the old ram limped heavily out of sight behind a boulder on the top of the opposite side of the ravine. Of course we followed at once, but no trace could we find of the wounded goat beyond where we had last seen him. There was no blood, and the ground being all rock and stone, his footsteps had left no trace. The evening was fast closing in, and to add to our difficulties a heavy shower of cold sleety rain commenced to fall. For the time at least we were beaten, but for all that I felt assured that the old ram was not far off, and by no means despaired of recovering him on the morrow. We were still searching about in the fading light when the Doctor came right on to us, returning from the upper part of the mountain. I soon explained matters to him, and on our way to camp it was arranged that Mustapha should go that same evening to his village, and return early the next morning with five or six peasants to assist us in the search for the wounded goat.

Before daylight the next morning he was back 
again with eight compatriots, and we all of us, Mr. J., the Doctor and I, with Mustapha, Moussa, and eight beaters - made an early start for the mountain, I, at any rate, fully expecting that we should find the wounded goat without much difficulty. We naturally thought that, from the point where we had last seen him, the wounded animal would have continued his flight along the mountain-side, keeping the same general direction he had previously held, especially as only a couple of hundred yards in front there was a thickly wooded ravine for which the Doctor and Mustapha thought he would be almost certain to make. The whole morning we beat this ravine, and then went on along the mountain-side until we had got so far that I felt sure that no animal of any size could have come that distance with a broken hind leg. I then suggested to the Doctor that immediately after we had last seen it, the wounded goat might have doubled back and gone away in exactly the opposite direction to that we had expected it to take; and we thereupon retraced our steps and returned to our starting-point. It was, however, already late in the afternoon; and the beaters, who, I thought, had been working very badly all day, worked worse than ever, and we eventually returned to camp without the goat. Although much disheartened, I by no means despaired of yet recovering the goat, for from my long experience of such matters I knew that with a broken hind leg he could hardly have got to more than a mile 
or so from where we had last seen him. I also now felt pretty sure that he must have gone back. The following morning was Sunday, February Io, and I resolved to devote the morning to the further search for the goat, and then go on and take the eagle's nest. As I was not satisfied with the beaters I had had the previous day, I dismissed them, but took Manoli with us, leaving Pabli alone in camp.

On reaching the spot once more where we had last seen the goat, we again fanned out, and searching carefully along the mountain-side, in the opposite direction to that we had taken the day before, had not proceeded half a mile when I heard a wild halloo below me; and the next instant the Doctor, who was not far from me, called out, "Monsieur J. l'a vu; le grand; il est mort." How I tore down that hillside! and how joyful were the emotions I experienced when I found Mr. J., Manoli, and Moussa standing over the dead body of the great one-horned ram, I leave my readers to imagine. It was not long before I had the tape over his one magnificently curved horn. It proved to measure forty-four inches over the curve, and nine and one-half inches in circumference at the base; and the long black beard taped eleven inches. Cut off with plenty of neck and shoulder skin, to allow the head to be turned round sideways against the wall, showing the full sweep of the one great horn, I saw at once that it would make a magnificent trophy, and promptly set 
about cutting it off accordingly. The other horn was broken short off about six inches from the skull, and the injury I should think must have been caused by a bullet.

On examining the carcass, I found that the shot fired across the valley had hit him just in front of the left thigh, and trending slightly backwards through the intestines had smashed the right thigh-bone rather high up just below the hip, and then passed out, making a hole through the skin quite as large as would have been made by an expanding .450-bore bullet. The last shot fired at close quarters, as he rushed down the side of the ravine in which we had found him lying, had entered in the flank and passed up through the stomach, but had not left the body. Considering the severity of these two wounds, I think the tenacity of life displayed by this old goat little short of marvellous. With a broken hip and very severe internal injuries in addition, he had yet managed to climb up and down the sides of several steep ravines and put a distance of many hundred yards between himself and his enemies before finally lying down to die.

When we found him he could not have been long dead, and on the preceding afternoon some of the peasants whom I had hired to assist in the search for the wounded animal must have passed quite close to where he was lying, still alive but unable to move. Strange to say, not a drop of blood had exuded from 


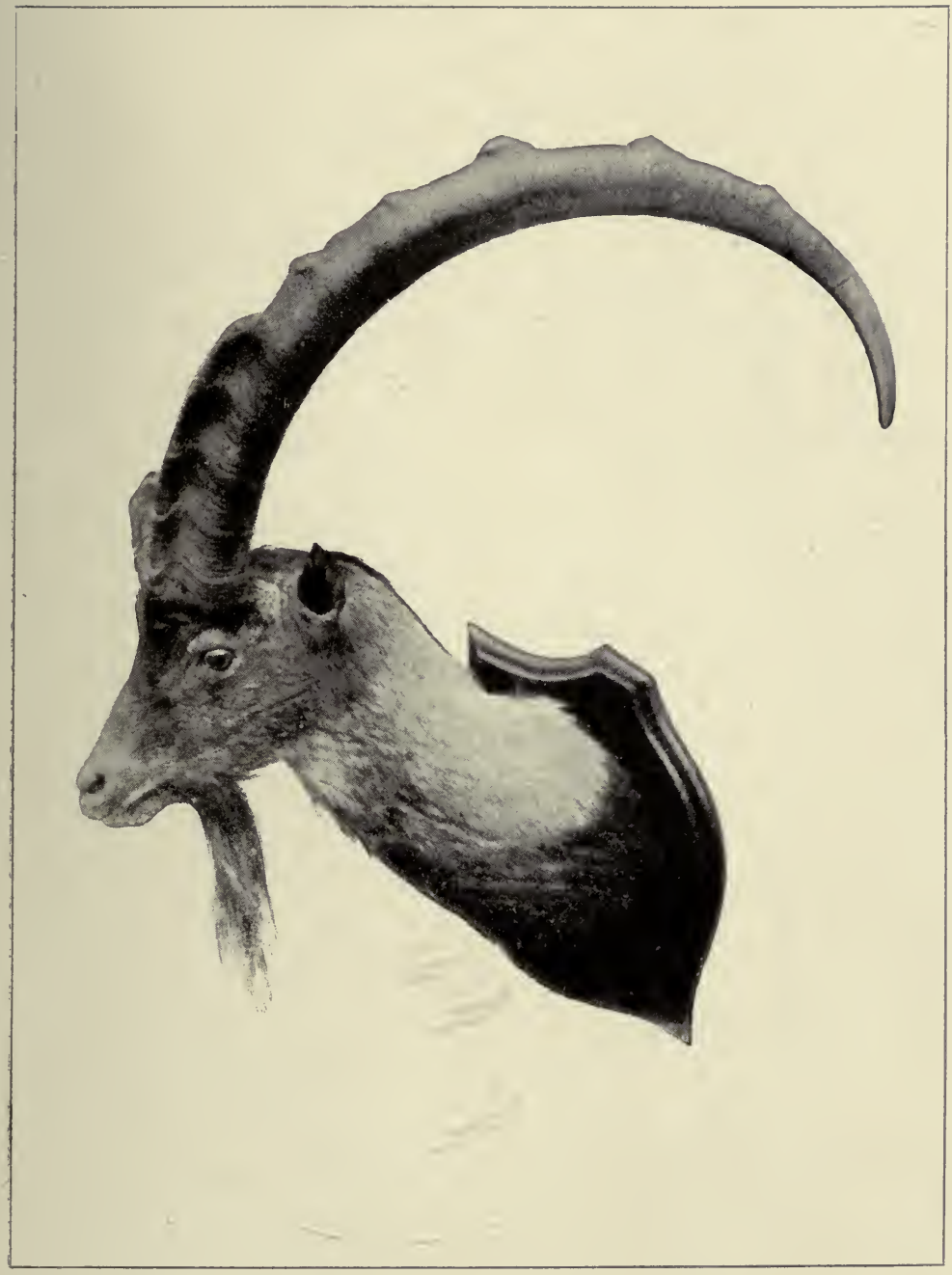

HEAD OF THE BIG ONE-HORNED WILD GOAT OF THE MAIMUN DAGH

Wounded on February 8, and found dead on February 10, 1895

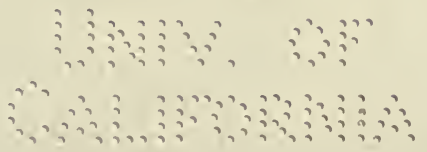



the bullet-holes, not even on the spot where we found him dead, and where he must have lain for a long time. With the first goat I had killed it was the same, for although being hit through the lungs, he had thrown out blood very freely from his mouth and nostrils, none had run out from the bullet-holes. The very large ram, too, which the Turkish hunter found dead, and which I have, I think, every reason to believe had died from a wound inflicted by my rifle, had left no blood spoor. Are these cases of no effusion of blood from bullet-wounds mere coincidences, or is it the case that, speaking generally, wounds inflicted by the .303 rifle with expanding bullets do not cause such an effusion of blood externally as would be the case with rifles of larger bore?

The three wounds I was able to examine were not tiny holes drilled by solid bullets, but were made by bullets that had expanded on impact, and which had cut jagged wounds of the diameter of a shilling through everything they had touched; and possibly it is the jagged nature of the wounds inflicted that accounts for the want of hæmorrhage; for a hollowpointed leaden bullet (if it does not break up) simply expands and makes a clean wound, whilst the hollowpointed nickel-coated .303 bullet shreds up into sharpedged ribbons of the nickel coating for half its length, each of which is bent over towards the base of the bullet, and which form altogether an irregular face of half an inch or more in diameter. Is it not pos- 
sible that small blood-vessels cut by such a jaggededged bullet driven through them at an enormous velocity immediately contract in such a way as to prevent the hæmorrhage which would result from a cleaner wound? I would be content to regard my very limited personal experience of want of blood spoor, after wounding an animal with a .303-bore rifle, as a mere accident, but I have heard similar complaints in other quarters, and I therefore propound a theory to account for it, which may or may not hold water. This want of blood from a flesh-wound is the one fault I have to find with the .303 -bore rifle, as its trajectory is very low, giving one a good chance at ranges where the shooting would be very uncertain with other rifles, whilst the wounds it inflicts are, if anything, more severe than would be caused by a .450 -bore rifle with expanding bullet of the best kind.

I will now endeavour to bring my all too long account of goat-hunting on the Maimun Dagh to a speedy close. After cutting off the old ram's head and giving it to Manoli to carry, I sent Mustapha back to the camp with the carcass; and the rest of us then went on to the eagle's nest, and after a great deal of trouble I at length became possessed of the one egg which it contained. This was eventually identified by my friend, Mr. John Young, the wellknown ornithologist, as that of a short-toed eagle (Circaëtus gallicus) a species widely distributed over 
Europe, but unknown, I believe, in the British Isles. As the Doctor and Mr. J. were anxious that we should try the usual method of driving for wild goats, we devoted Monday and Tuesday to this form of sport, but had no luck whatever. On Monday the weather was very bad, and we all got wet through; and when it was not raining, the mist was so dense on the mountain that goats might have passed within twenty yards of us without being seen. As a matter of fact, I do not think any did pass, or we should have heard them, but, at any rate, we saw none. On Tuesday we were again unfortunate; and though some small worthless goats were seen in the distance, and the beaters reported that two big rams had broken back through their line, neither the Doctor, Mr. J., nor myself got a shot. That evening we passed at Chardak station, and on the following morning, after I had secured the big ram's head from the Turkish hunter who had found it lying dead, as above described, Mr. J. and I bade adieu to the Doctor and took the train to Smyrna, where we arrived on the evening of Wednesday, February I3, being met at the station by our mutual friend, Mr. H. O. W., beneath whose hospitable roof I again spent a most pleasant evening.

The next day I left for England, and travelling via Salonika, Belgrade, Vienna, and Paris, reached London on the evening of February I9, after an absence of between three and four weeks, a little 
more than one-third of which only had been actually spent on the Maimun Dagh. Measured by the number of shots one is likely to get at big game, Asia Minor is not a very attractive field for sportsmen, but with perseverance and a certain amount of luck, some very fine trophies are to be obtained in that country, and personally I have been so well pleased with my two visits there after deer and goats, that I trust I may live to hear once more the great stags roaring in the autumn nights beneath the forests of the $\mathrm{Ak}$ Dagh, and see again on their native crags such fine old billy-goats as those whose heads rewarded my last hurried trip to the Monkey Mountain. 
TRAVEL, SPORT, AND ORNITHOLOGY IN ASIA MINOR

N Tuesday, Feb. I6, I897, I left Smyrna on a journey to the Murad Dagh, a mountain range in the interior of the country, where I hoped to come across deer, and where I also thought I should be likely to find the nesting-places of the various species of eagles and vultures that are indigenous to Asia Minor. February may seem somewhat early for birds' nesting, but the larger birds of prey I knew to be early breeders in Asia Minor; and as I had taken a nest of the short-toed eagle ( $\mathrm{Cir}$ caëtus gallicus) containing one egg, in that country, on the Ioth of February, I894, I thought it probable that the golden and imperial eagles, as well as the cinereous and griffon vultures, would also be likely to lay their eggs during the same month or early in March.

Starting from the seacoast at eight in the morning by the Aidin railway, the town of Chivril was reached at 7.30 in the evening. Although a sprinkling of snow still lay on the tops of the mountains which enclose the beautiful Bay of Smyrna, the air had been warm and balmy during the few days I had spent 


\section{6}

there; indeed, so mild was the climate that the violets were in full bloom, and some of the rose bushes were already flowering in the open air. No breath of spring, however, had yet reached Chivril, which lies at an altitude of over three thousand feet above sea level. As the train drew up at the railway terminus, and I emerged from the comfortable carriage, and turned my back on the last emblem of European civilisation I was to see for some time, a bitter wind came howling across the surrounding dreary treeless plains, penetrating through coat and vest to my very skin. All the little pools, too, in the muddy roads round the station were frozen into solid ice, whilst the mighty mass of the Ak Dagh (White Mountain), although some miles distant, stood out clearly in the bright moonlight, its domes and peaks all buried beneath one vast unbroken pall of new-fallen snow.

The Greek station-master, who had lately built a small hotel, soon provided me with an excellent dinner, and then gave me a comfortable bed in his house, where I slept well and warmly until about six o'clock the next morning, when I got up, as I wished to make an early start. I had been accompanied from Smyrna by two servants, - Theodore, a Greek, who, having lived for some years in America, spoke English well, and also a little Turkish, and who was therefore my interpreter as well as my cook; and Mustapha, a Turk, who spoke Greek, as well as his own language, a steady, reliable man, who acted as general servant 
and intermediary between myself and the natives of the country. A friend in Smyrna had telegraphed to one of his correspondents in the town of Ouchak, to have pack ponies sent down in charge of a responsible man to meet me in Chivril. These had duly arrived on the previous day, together with riding horses for Theodore, Mustapha, and myself; but as the men in charge of the horses had gone off to sleep in the village near the station, and as the weather on the following morning was bitterly cold, it was some time before Mustapha could get them together, and past eight o'clock when we finally got all the loads packed, and at last made a start for the town of Ouchak.

As soon as we were clear of the straggling village of Chivril, Theodore and I rode on ahead, accompanied by Mustapha and the Turk who had come from Ouchak with the pack ponies, which latter (three in number) came on more slowly behind, in charge of two men on foot. Our route lay over a spur of the hills to the right of Chivril and then across an open treeless steppe. The early morning had been bright though cold, but as we advanced great banks of cloud blew across the sky, and the wind increased to a regular hurricane. The cold soon became intense; and although we walked and drove our riding ponies in front of us, we found it impossible to keep warm. I had left my gloves in one of the packs, and therefore had to keep my hands buried under my coat, or in 
my trousers' pockets, as exposure to the wind numbed my fingers instantly.

After three intensely disagreeable hours, we entered a tract of country covered with velonia forests, where we were protected to a considerable extent from the bitter wind. The velonia-tree is a species of oak, bearing acorns in profusion, the cups of which are rough and hairy. It is from these acorn cups that the celebrated velonia dye is made; they are collected by the Turkish peasantry in many parts of Asia Minor, and carried in bags on the backs of camels and donkeys to the railways, by which they are conveyed to the ports and exported to Europe. In the forests I have seen, the trees were always small, growing well apart from one another and without any kind of scrub or undergrowth beneath them. The acorns with which the ground was covered would fatten herds of tame swine, were Asia Minor a Christian country; but as it is, they are only eaten by the wild boars, which feed on them at night, but retire before daylight to the shelter of the scrub-covered slopes of the neighbouring mountains; for although the Turks consider these animals to be unclean beasts in common with the domestic hog, they destroy them whenever they can, on account of the damage they do to their crops.

At about one o'clock we reached a small Turkish village, where our horses were relieved of their saddles for the first time since leaving Chivril. The head man 
of the village asked us to his house, and spread a carpet for us to sit on. This house, like all the others in the village, was a square structure built of pine logs, divided into an upper and lower chamber, the flat roof

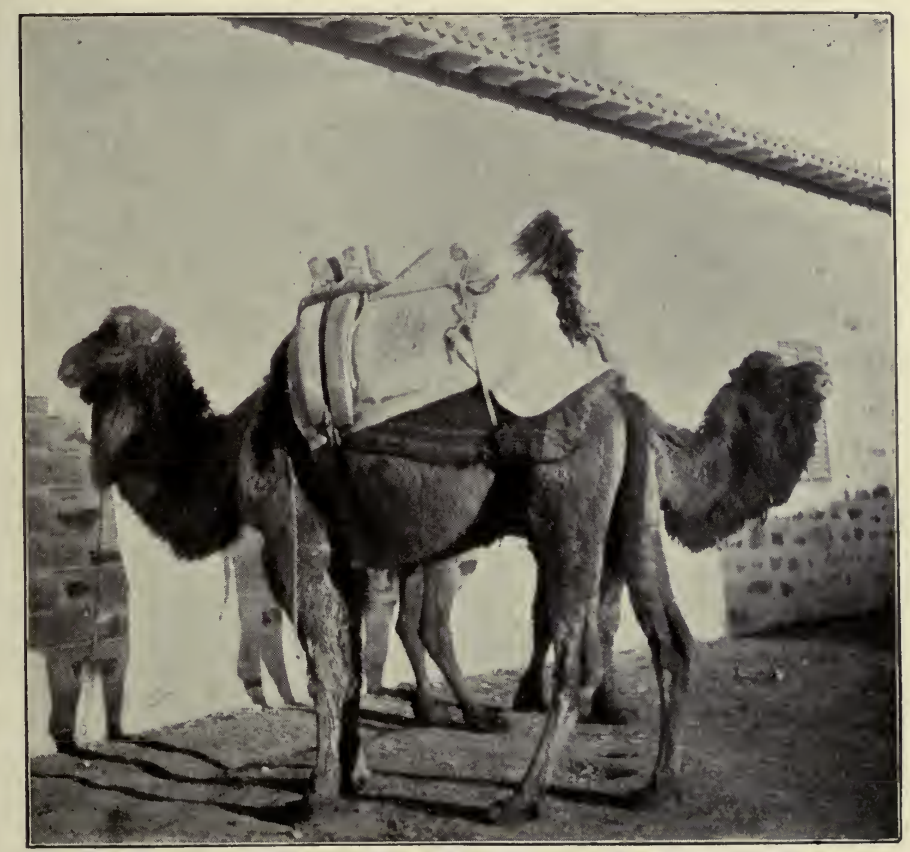

Camels that have JUST CaRRied Down LoAds to the RaIlway TERMINUS

being covered with a thick layer of mud or turf. We ascended by a flight of wooden steps to the upper chamber, where we found a log fire burning in the ample hearth, the warmth of which was very grateful after our long exposure to the cold wind outside. Our 
host was most hospitable, and soon provided us with a meal of hard-boiled eggs and thin sheets of unleavened bread, made, I should think, by compressing the kneaded dough between two hot sheets of iron. He also brought us some home-made syrup of grapes, and prepared us coffee in the Turkish style from beans, which were roasted and crushed before our eyes. The carpet on which we sat had been made, he told us, in the village, and was the only home-made article I saw, that was not of the most primitive description; and indeed wherever I have travelled in Asia Minor, putting aside the beautiful carpets which are made in Ouchak and elsewhere, I have been struck with the conservatism of the people in their arts and handicrafts. Their wooden ploughs, their houses, their cartwheels, made of a solid sphere of wood, the materials of which their clothes are made, the entire surroundings, in fact, of their daily lives, are to-day exactly what they must have been a thousand years ago. The art of carpet-making has not been evolved under Turkish rule, but is a survival from pre-Turkish times. Railways are to-day creeping eastwards through Asia Minor, but they have but little civilising influence on the lives of the people of the country, whose old world ploughs and carts are often to be seen in the immediate proximity of that triumph of human mechanical skill, a modern locomotive engine. The station-masters, telegraph clerks, and indeed all the employés on the railway lines are Greeks, a people who are as in- 


\section{SP PORT AND TRAVEL}

IOI

telligent and progressive as the Turks are dull and intellectually stagnant.

What struck me as very remarkable in this part of Asia Minor was the diversity of types one sees

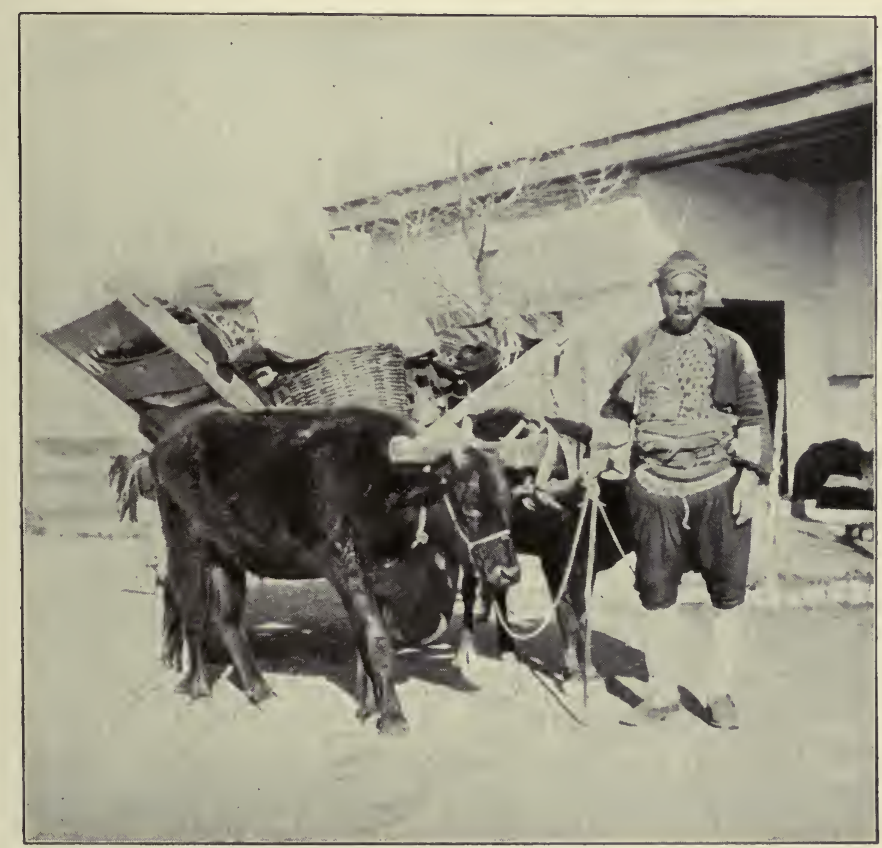

Country Cart with Turkish Driver in Asia Minor

amongst the people, even in the same village or encampment, for they divide themselves, I believe, into two classes, the Turks or Turcomans, who live in villages, and the Yuruks, who are pastoral nomads living in tents, the site of which they change at different seasons of the year. Amongst both sec- 
tions, men with fair or reddish hair and blue or grey eyes are common; and whilst some of these fair men are handsome, others have snub noses and the generally irregular features that may be seen any day in the streets of a western European city. On the other hand the prevailing type is dark-haired, with a complexion that is sometimes excessively swarthy, often with high aquiline features, of an altogether nonEuropean caste. The origin of the fair-skinned, blueeyed people, who are now scattered amongst the more numerous swarthy inhabitants of Asia Minor, is traceable, I am told, to a Gaulish colony which was established in that country before the Christian era, the inhabitants of which were known in the time of Saint Paul as Galatians. Fair and dark alike, the people amongst whom I travelled are now all Mohammedans, and probably very fanatical when their religious prejudices are excited. Otherwise they are a very agreeable people to travel amongst, - unprogressive and unintellectual, no doubt, but friendly and hospitable, courteous in their manners, and more honest and less extortionate probably than many Christian races. Physically, they are, as a rule, strong hardy-looking men, frugal, sober, and industrious in their way of living, and self-evidently splendid raw material for the Turkish army.

As the baggage ponies did not reach the village until some time after our own arrival, and as it was necessary to give them a rest and a feed before pro- 
ceeding on our journey, it was getting on for three o'clock before we again got under way, and it was past eight, and bright moonlight, when we at last rode into the town of Ouchak. We went straight to the house of a Turkish gentleman, to whom I had a letter of introduction, and who is the local agent of a large carpet-making establishment. He received us most hospitably, gave us a most excellent dinner of many courses, everything being prepared in the Turkish style, and then had very comfortable beds of soft cushions and quilts laid down on the floor for Theodore and myself, Mustapha finding accommodation amongst the servants of the house.

On the following morning, our host provided us with a most sumptuous breakfast, and then took us for a stroll round the town, whilst arrangements were being made to hire a couple of country carts to convey us and our luggage to the foot of the Murad Dagh. We first visited some rough sheds where carpets were being made. Here the workers were all Greek women and girls, some of them mere children. Being Christians, these women were unveiled. They all looked fresh-complexioned and healthy, but I did not think them remarkable for beauty. It was really wonderful to watch the gradual evolution of these beautiful carpets under the deft fingers of these poorly dressed women, who were carrying on their work amidst the roughest, not to say, most squalid surroundings. The exquisite colouring and tasteful 
patterns of the works of art which they slowly produced, seemed as incongruous and out of harmony with their environment as would be a cluster of beautiful wild flowers growing in the street of a London slum. It is beyond me to explain clearly how these carpets are worked; but they are made entirely by hand, and each carpet is composed of thousands or millions of knots, tied in various coloured wools, on cross threads stretched on a frame. Several women are employed on each carpet, and they sit in a row before the frame, and work from a small painted pattern hung up in front of them. The quickness with which these women work, and the wonderful accuracy of hand and eye and sense of colour, required to imitate the coloured designs before them, must be seen to be fully appreciated. The finished carpet, which although it has been made by several women all working independently, and all tying countless little knots of wool of every shade of colour, looks, until carefully examined, as though it were the work of a machine, and is undoubtedly a real work of art. For my part, I came to the conclusion that, at the price at which they were sold, Turkish hand-made carpets are the cheapest products of skilled labour in the whole world.

Ouchak is, I think, one of the largest towns in the interior of Asia Minor and has a population of twenty thousand inhabitants. With the exception of the mosques, of which I counted thirteen, and a very few other buildings, the entire town is built of 
wood. About two years ago, one-third of it was destroyed by fire, and I noticed several stone buildings being erected on the site of the wooden houses that had been burnt down. I noticed too that the workmen employed on these buildings were all Europeans,

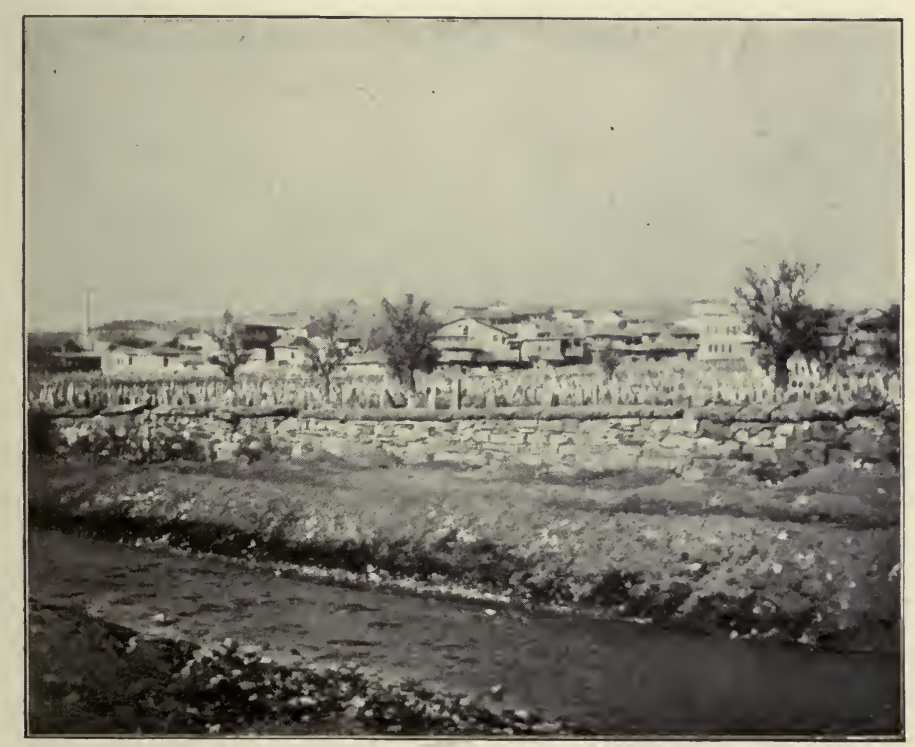

Portion of the Town of Ouchak; Interior of Asia Minor; with LaRge Graveyard in the Foreground

Greeks, and Italians, and therefore imagine that the native Turks are not capable of putting up anything but rough wooden buildings. The streets of Ouchak were at the time of my visit in such a wretched condition that I doubt if they could ever have been repaired since the city was founded. Luckily, at 
the time of my visit all the bogs and mud holes were frozen hard, and we had not therefore to wade through them. A prominent feature in the town is the immense graveyard, which, although several acres in extent, must long ago have received its full complement of dead, as it presents the appearance of a forest of gravestones, all of which look old and weatherworn.

On our way back from the sheds where the carpets were being made, we passed a Greek church in which a service was being held, so I went inside with Theodore, and listened for some time to the preaching of a long-haired, full-bearded priest. $\mathrm{He}$ rather sang than spoke, quivering his voice and singing through his nose just as I have heard a Mohammedan Mullah preaching in Constantinople or a Japanese reciting poetry. This Greek church was a large and substantial building, from which I should judge that there is a considerable Greek population in Ouchak, and also that they enjoy complete religious toleration.

It was not until after eleven o'clock that we got away from Ouchak in two rough carts, each drawn by two strong wiry little horses. From this time until eight in the evening we travelled over roads so abominably bad that we sometimes had to leave them to get along at all. During the whole day the horses were never unharnessed, though two short halts were made in order to feed them, whilst still 
attached to the carts. Some time after the moon had risen, we reached the village we were making for and took up our quarters in a Turkish "han," or house for travellers, which on our arrival was filled with people, who, however, gradually took their departure one by

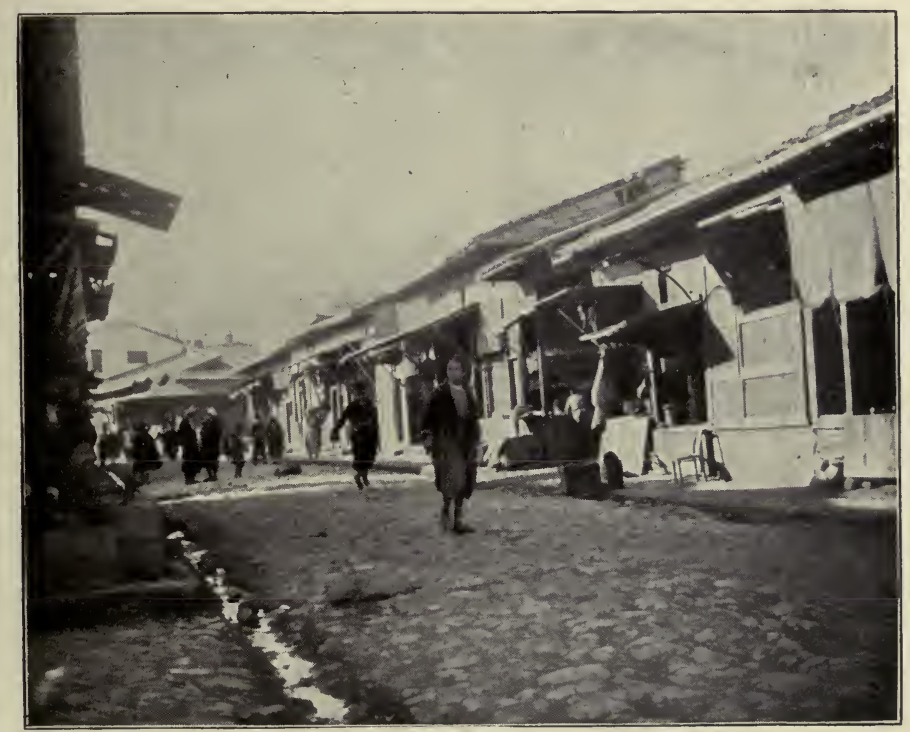

A Street in Ouchak

one, until I and my men were in sole possession of the room. These "hans" exist in every village, and I believe that one may travel from one end of the Turkish Empire to the other, without spending a penny for food or shelter. The traveller is fed on the day of his arrival, and on the following day as well, whilst resting, but on the third day he must proceed on his 
journey. On this occasion, having plenty of food of my own, I told the man who seemed to be the presiding genius of the "han" not to prepare anything, and Theodore soon had a cup of tea and some eggs and bread ready for me. After making a good meal, I put up my stretcher, and passed a comfortable night.

On the following morning, we got away soon after eight o'clock. The weather was bright but very cold, a bitter wind making things unpleasant. In two hours' time we reached a village just at the foot of the Murad Mountains. Here we discharged our carts and hired some horses and donkeys to carry our baggage to a camping place in the mountains, which we reached in the afternoon. The snow was lying all round, but not very thickly, and we chose a place to pitch the tents close to a little spring of good water and under some large fir-trees, where the ground was free from snow. The rest of the afternoon was spent in pitching camp.

I was now once more in the home of the "maral," as naturalists have named the great grey stag of Western Asia. This magnificent animal is an inhabitant of Persia and the mountain ranges of the Caucasus and Daghistan, and is also found in certain districts of Asia Minor where conditions suitable to its requirements occur, these requirements being well-watered mountain ranges, thickly covered with forests of pine, juniper, and in some parts beech and oak trees. I have seen some magnificent pairs of horns of these 
great stags, brought down to Constantinople from no one exactly knows where, though probably from the wild mountainous country to the south of the Black Sea.

One of these heads measures forty-eight and a half inches along the beam, carries twenty-one points, and is seven and a half inches in circumference between the second and third tines. ${ }^{1} \quad$ Another beautiful pair of horns, to which only a very small piece of the skull is attached, weighs just twenty pounds. These heads would compare favourably with most Caucasian heads, though I believe that it is in the Caucasus that the biggest "maral" horns in existence have been obtained by Russian sportsmen and our own countryman, Mr. St. George Littledale. I am inclined to think that the red deer of Roumelia and Turkey in Europe, as also the large and mighty antlered race found in Galicia and Hungary, are, if not identical with the Cervus maral of Western Asia, at any rate more nearly allied to that species than they are to the smaller and shorter-skulled red deer of the British Isles. At any rate, all the skulls I have seen of deer shot in Hungary, Galicia, and Turkey were very long in the face and far more like the skulls of the Asiatic maral than those of red deer from Western Europe. When in condition, a good maral stag will weigh forty stone clean, and exceptional

${ }^{1}$ Quite correct: I measured the above-mentioned heads myself. They are at Constantinople in the possession of Sir W. Whittall and his son. 
animals probably a good deal more. My acquaintance with these great deer is not as extensive as I could wish, and I have not yet discovered a country in which they were anything but few and far between. I first hunted them in the autumn of 1894 on the Ak Dagh, or White Mountain; but I only succeeded in killing one stag, though I was camped high up in the mountains in the midst of the ground they most frequented for a month, and was continually looking for them. This may seem very poor sport, and no doubt it is so from a certain point of view, but the sportsman who wants to kill a lot of beasts had better go to some other part of the world than Asia Minor. In that country there are grand prizes to be won certainly, but they are few and far between, and require a lot of patience and perseverance in the getting.

It was during my first visit to Asia Minor, in I 894, that one morning, after a fortnight's unsuccessful hunting, I heard a stag roar apparently just beyond the top of a wooded ridge, that rose from the ravine, in which my native hunter and myself found ourselves. Roar succeeded roar; and presently we saw four hinds filing slowly through the trees one behind the other on the top of the ridge. They were soon followed by a stag, whose great branching antlers were plainly visible. I saw the hinds pass on and disappear; but the stag never seemed to me to pass a certain cluster of trees, and as he had ceased to roar, I thought he had probably halted and lain down, as the sun was already 


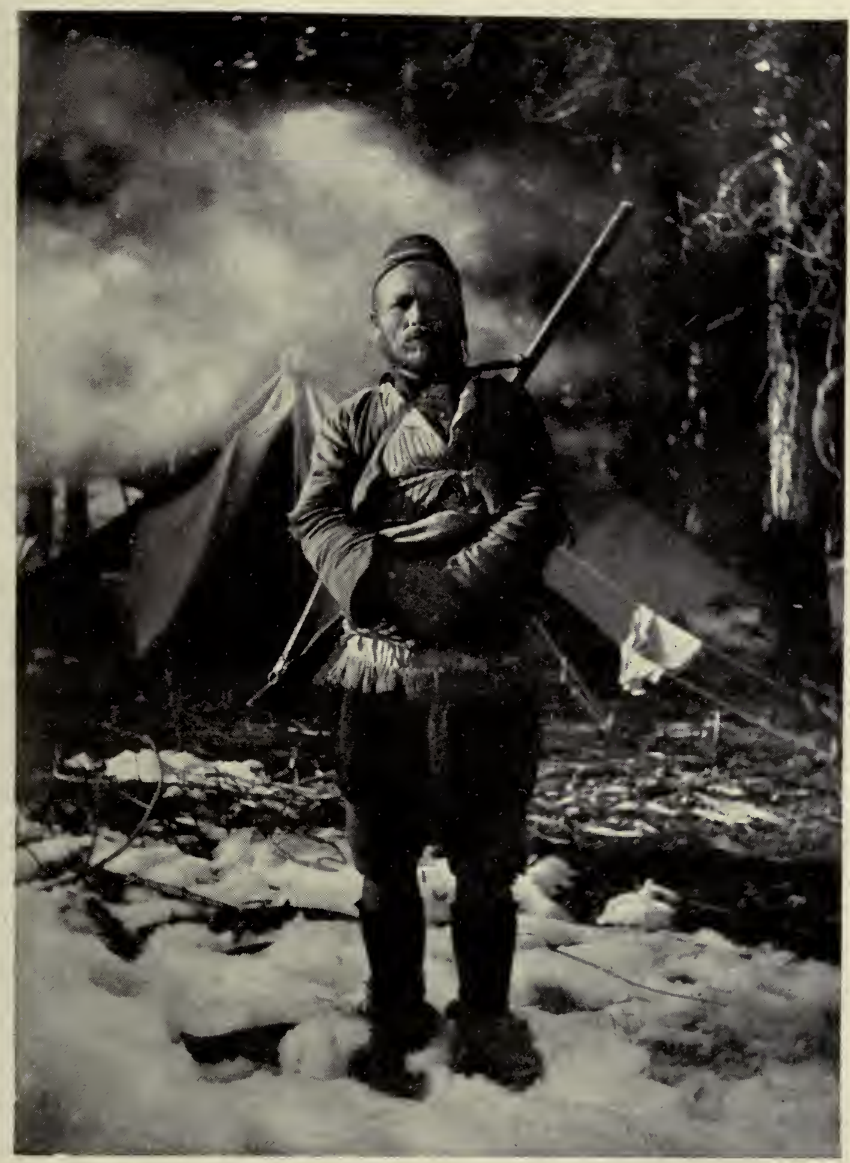

YURUK HUNTER

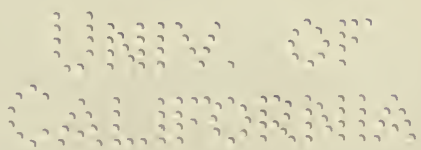



high. This idea I endeavoured to convey in pantomime to my companion, for I could not speak a word of 'Turkish; but he gave me to understand by very expressive signs that I was mistaken, and that the stag had passed on after the hinds. Now the Turkish hill men are extraordinarily keen-sighted, and I therefore came to the conclusion that my shikarry had really caught a glimpse of the stag moving forwards, which I had missed. The wind being favourable, we now proceeded to climb cautiously up the well-wooded hillside towards the spot where I had last seen the stag, but from which I thought he had moved. My companion was in front and had almost reached the crest of the rise, when he suddenly ducked his head in a way that assured me he had seen something. I was close behind him, and without waiting an instant, pushed past him with my rifle at the ready. I was just in time to see the head and horns of the great stag, as it rose from the spot where it had been lying and dashed out of sight amongst the trees. I never caught a glimpse of anything but its head and horns, as just where it had been lying there was a thick growth of underwood. However, I had been right, and my Turkish hunter wrong, as to the stag having moved on; and had we both only been certain that he had stopped and lain down, I might very likely have compassed his death.

After this we followed his tracks for a long way until they led us almost to the top of the moun- 
tain. We saw him several times a long way off, always following slowly behind his four hinds. At length we lost the tracks, but crossed the shoulder of the mountain, and worked down the other side in the direction they had been heading. It was late in the evening; and we had just crept to a ridge of rocks which commanded a good view of some corries below us, when I caught sight of two hinds feeding amongst some bushes at the head of a narrow gully. I thought it quite possible that more deer might be lower down the ravine out of sight, so signing to my companion to sit tight, and not show himself, I crept round the rocks, and then made rather a difficult stalk down the hillside and at length reached a single rock, within two hundred yards of the hinds, which were quite unconscious of my proximity, as they had not seen me, and the wind was blowing strongly from them towards where I sat.

I watched them for a long time, and as they kept feeding farther and farther up the hillside, and no more deer came in sight in the gully, I made sure there could be no more there; and as it was getting late, I left my shelter and crept cautiously back again to the rocks, where I had left my companion, whom I rejoined without disturbing the deer. As I cared very little whether these hinds became aware of my presence or not, I thought I would test their powers of hearing; I therefore gave a not very loud call, which evidently did not reach their ears, but when 
I repeated the call in a louder key, they at once stopped feeding, and after looking towards us with cocked ears for a few seconds, trotted off up the mountain-side. They had not gone far when two other hinds which had evidently taken the alarm from them, came trotting out of the gully, followed immediately by a magnificent stag, the same, no doubt, I had been after all the day. Oh, why had he not come out of the gully and shown himself when I was behind the rock down the hillside? Then I could have had a shot at him at less than two hundred yards, but now the distance which separated us was quite four. Well! there was just a chance of hitting him, so I raised the sight and fired, but missed, as I feared I should do. Immediately the shot was fired, my shikarry seized me by the hand, and pulling me forwards intimated that we must run and try to cut the deer off at a shoulder of the hill where they seemed likely to pass.

As they were somewhat below us, we reached the pass before them; and I took up a sitting position, and with my elbows rested on my knees, waited for them. Very soon the four hinds came in sight, and passed within a hundred yards of where I was sitting. As they trotted past me one behind the other, they looked for all the world like Waterbuck ${ }^{1}$ cows. When I saw the hinds approaching, my heart

1 The Waterbuck is one of the commonest of the South African antelopes. 
beat high with hope, for I made sure that the stag would not be far behind them; but he never appeared, nor did I see him again, for that day at least. The cunning beast, with a sagacity that outweighed his chivalry, had realised, when my bullet whizzed past him, that danger threatened; and so instead of followthe ladies of his harem, had left them to do as they pleased, and gone off along the side of the hill by himself. There was nothing more to be done. The night was ciosing in, and we still had a long tramp back to camp, so dispirited, dejected, and disappointed, I trudged wearily home behind my guide, "la mort dans l'âme," as the French say.

By this time I knew the mountain well, and required no guide to take me about or bring me back to camp, so I determined to try my luck on the following day unaccompanied by a native hunter. I was up before the sun on the morning of Oct. I9, 1894, and was early in that part of the mountain where we had first heard the big stag roar the previous day; but the sombre pine forests were silent, and I neither saw nor heard anything the livelong day, though late in the afternoon I came across a small clearing surrounded by rocks and pine-trees, where a combat had evidently taken place between two big stags on the previous night, as their splayed-out hoofs had cut deep grooves in the ground, and in one place I found a good deal of blood sprinkled about. On my way back to camp in the evening, and when still some three miles distant 
from our bivouac, I suddenly heard a slight noise on the hillside above me. I was just then making my way along the edge of a small watercourse which led up to near the top of a ridge which I had to cross before getting home. The hillsides above me were bare and stony, with little or no vegetation save a few scattered juniper-trees and bushes. The noise I had heard was the clatter of displaced stones; and on turning my eyes upwards in the direction of the sound, I immediately saw four hinds and a stag moving along the hillside. No doubt these were the same animals I had been after the previous day. They were going at a slow trot, the stag following at some little distance behind the hinds, who had no doubt been the first to see me and take the alarm.

The distance between us I judged to be about three hundred yards, and the light was bad, as it was already late; but as the chance for a lucky shot was one that might not occur again, I determined to try it, so sitting down and taking a careful aim with the three hundred yards' sight, I pulled the trigger just as the point of the big stag's shoulder came in view. The report was followed by a dull thud which assured me that my bullet had found its billet; but as it afterwards proved, this first shot had struck the stag too far back behind the ribs, and had it not been improved upon, I probably should have lost him. He showed no sign of having been hit, but continued trotting slowly along behind the hinds. I fired two more shots at him in 
quick succession, but missed him with both. Hastily pushing in another cartridge, I drew in a long breath and prepared for as steady a shot as I was capable of, for I saw it would be my last, as the hinds were already almost hidden amongst some juniper scrub, and the stag was quite close to the same cover. But just as I got my sight on him, he halted, and half turned towards me. At that very moment I pulled the trigger, and as my ears caught the welcome thud of the bullet, I saw the great stag come bounding down the mountainside, and knew instinctively that it was the last headlong death-rush of an animal shot through the heart. He soon came down with a crash, and after rolling over twice lay still amongst the rocks and stones on the steep hillside.

Joyously, yet fearfully, I clambered up to where he lay, for I thought that his great branching antlers could not possibly have survived that headlong fall amongst the rocks and stones, without having sustained some irreparable damage; and I could hardly believe my eyes when I found that excepting that the point of one of the tines had been slightly damaged the beautiful head was still perfect. How can I describe my delight as I gazed upon the symmetrical branching antlers of the first stag that had ever fallen to my rifle? I had not, it is true, secured a maral head of the largest dimensions known, but still I had won a trophy well worth all the toil and disappointment it had cost me. The chief charm of this head to 


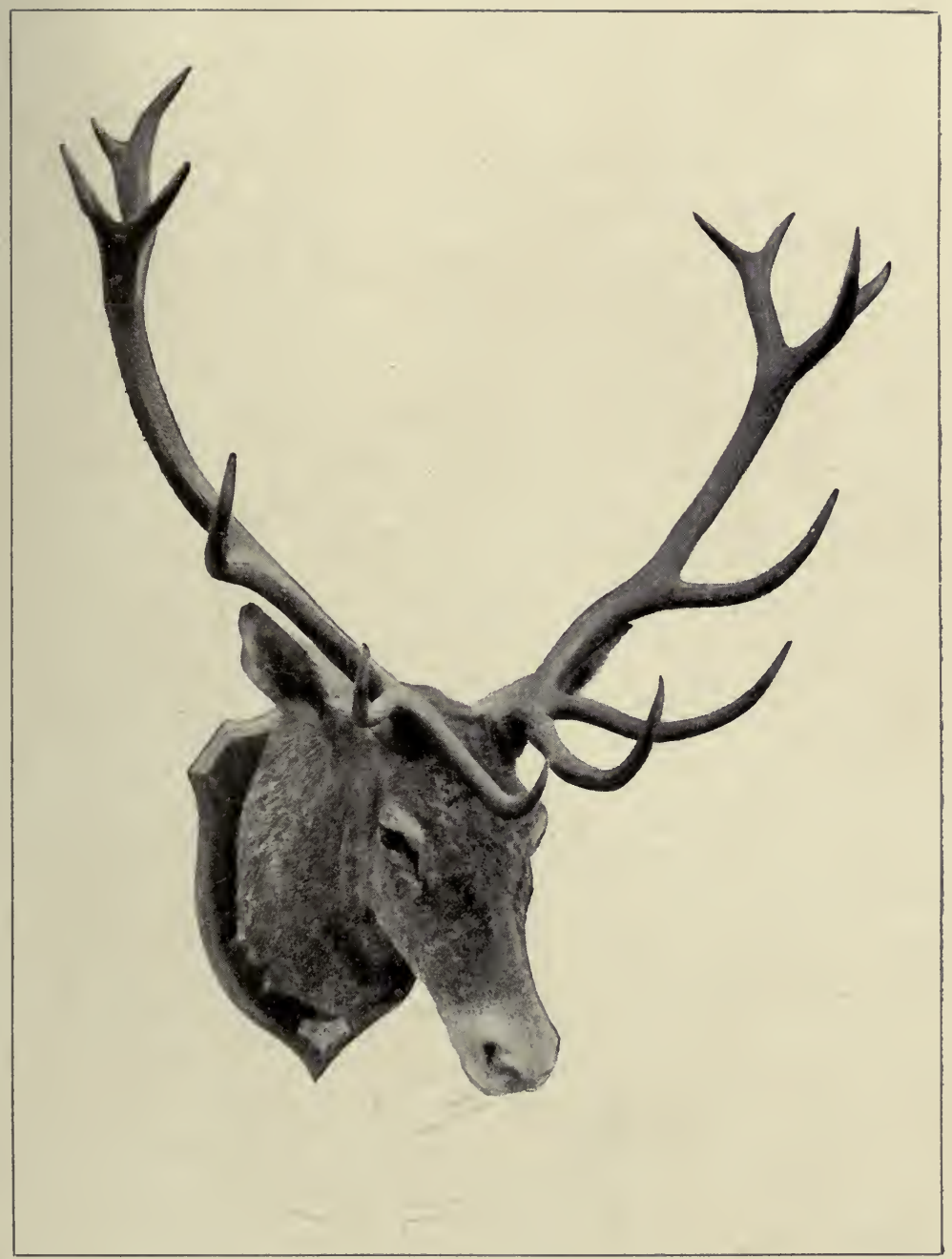

HEAD OF WEST ASIATIC RED DEER (CERVUS MARAL)

Shot on the Ak Dagh, Asia Minor, October, I894 

me is its wonderful symmetry, for in size it is but a second-class maral head. The measurements of the horns are as follows: length along the beam, 393/4 inches; circumference, between the second and third tine, $5 \frac{3}{4}$ inches; inside span, 36 inches; length of brow antler, $171 / 2$ inches; points, 15 ( $7 \times 8)$. The dusk was now coming on apace, and I was still some distance from camp, so I hastily covered the whole head and neck of my prize with heavy stones to preserve it from any prowling hyena, wolf, or jackal which might be about, for all these animals still frequent the mountain ranges of Asia Minor, and then walked home in the dark, being guided from the top of the ridge by the bivouac fires in the valley below.

On the following morning I was up by daylight, and accompanied by two Turks reached the carcass of the stag by sunrise. We found it untouched by any beast of prey. I had brought a scale with me, and after removing the offal from the carcass as well as the heart, lungs, and liver, I cut it up and weighed it in pieces, the aggregate weight of the several parts amounting to four hundred and fifty-seven pounds, or thirty-two stones, nine pounds. This stag, it must be remembered, was shot on October I9, towards the end of the rutting season, and was very much run down, so that had he been shot a month earlier when in high condition, he would probably have scaled forty stones clean. After this I shifted my camp, but remained hunting in the same range of 
mountains for another fortnight. I never got another shot at a stag, though I twice got near either to the same or two different animals. Once it was in thick timber, where although I just caught a glimpse of a great grey beast as he faded from sight amongst

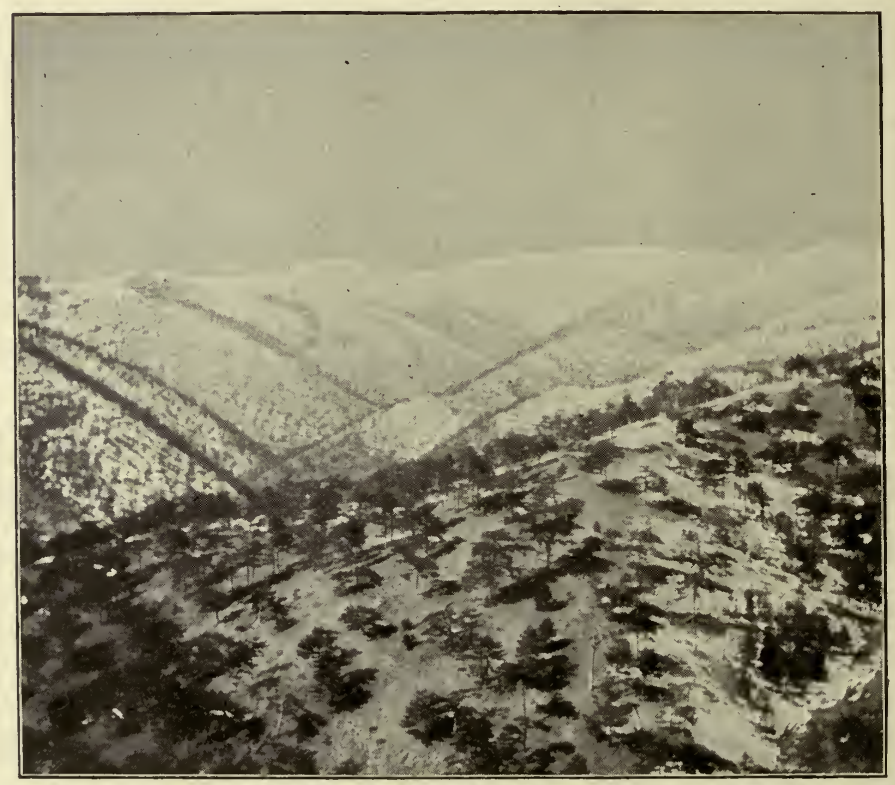

The Home of the Great Grey Stags, White Mountains, Asia Minor

the tree stems, I was unable to fire before he had disappeared, and again late one evening when a stag kept calling until I had got quite near him. Then, however, it became so dark that I was unable to see him, though I must have been very near, for as I gave it up and stepped out into an open space from the gloom of the 
trees amongst which I had hitherto been concealed, a hind saw me and gave a loud bark of alarm. She herself was, however, invisible amongst the dark shadows of the pine-trees.

I will now return to my second expedition in quest of a maral, nearly three years later, amongst the snows of the Murad Dagh.

It was February I9 when I reached my campingground towards the close of the Mohammedan Lent or Ramazan. At the end of this period of fasting comes the feast of Bairam. This festival was to commence on the appearance of the next new moon, which was due just at the end of February, before which time it would be necessary for me to break up my camp, as all Turks must go to mosque before the feast of Bairam, and will not do anything but eat and make merry during that period. Thus I only had a week during which to hunt.

During this time I was unsuccessful in securing the head of a good stag, though I very nearly succeeded in doing so; but as every one knows, in every kind of sport there is sometimes a very narrow margin between success and failure.

On February 22, we had a hard day climbing up and down steep snow slopes. My companions were two brothers, Yuruks, or dwellers in tents, who had pastured their flocks on these mountains all their lives. They were of the fair European-looking type, descendants possibly of the Galatians, and their pre- 
historic ancestors may have hunted the reindeer in France during the Glacial Period. They were both armed with long single-barrelled muzzle-loading guns of Turkish make. They had open, honest-looking faces, and were physically sturdy, well-built men, the elder of middle height, and the younger somewhat shorter. Unfortunately they were not quite as heavy as for my comfort I could have wished them to have been, as when toiling up steep snow slopes behind them, placing my feet carefully in their tracks, I found that I always sank much deeper than they did.

On the day in question, we found the fresh tracks of two deer, and followed them to near the head of a deep rocky corrie within a short distance of the summit of the Murad Dagh. In the snow it was difficult to tell whether these animals were males or females, but when we came in sight of them we found they were both hinds. Having no fresh meat in camp, I determined to try to shoot one, and had no difficulty in getting up to them. Indeed, as they were of no value, they seemed remarkably tame and stupid, for after I had crept to within one hundred yards of the one, and killed her with a shot through the lungs, the other stood, broadside on, looking stupidly at me for some time before she dashed off through the snow. The one I killed went rolling down a steep snow slope for several hundred feet, cannoning against two rocks on the way, and was only brought up by reaching the half-frozen 


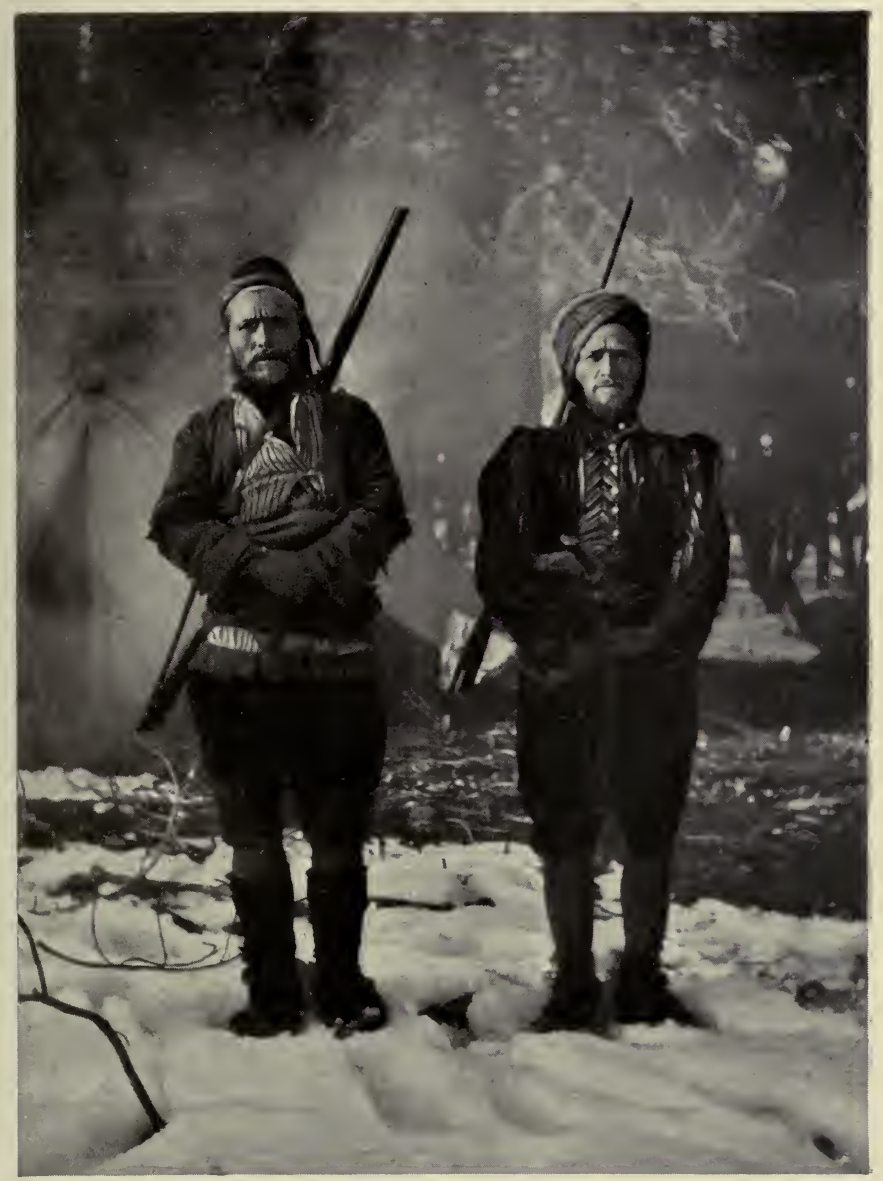

YURUK SHEPHERD HUNTERS OF THE FAIR TYPE Murad Dagh, Interior of Asia Minor

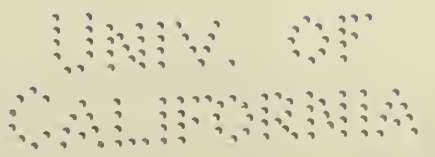



stream at the bottom of the corrie. After cutting up the deer, we first climbed to the top of one of the highest parts of the Murad Dagh, an open, treeless dome, deeply covered with a sheet of pure white snow. Here the walking was excellent, as there was a hard crust on the snow, through which we did not sink. Near the top of the mountain at an altitude of about seven thousand feet above sea level, we put up a hare of grey-brown colour, which appeared to be identical with the hares of the plains, and which certainly had no white about it, so I suppose the Alpine hare does not exist in this part of Asia Minor, its place being taken by the grey hare of the plains.

The following day, February 23, was a bitterly disappointing one, as on it I saw three magnificent grey stags, but failed to secure the coveted head of any one of them. We got their spoor early in the morning and followed it for a long way, or rather kept on cutting it; for as the wind was bad, we often left it, and made détours in the hope of sighting the deer without giving them our wind. It was whilst making one of these détours that we suddenly sighted the stags, and at once dropped, and lay hidden amongst some rocks on the edge of a broad ravine. When we first saw them, they were about five hundred yards off and were coming straight towards us; and looking at the course they were holding, and the formation of the ground, it really seemed as if they would have passed within one hundred yards of where we lay, and 
then - but it is useless speculating as to what might then have happened.

They came steadily on to within about two hundred and fifty yards of where we sat, and then halted amongst some larches, where for the moment they were hidden from view. In a short time, the foremost stag appeared again, but, alas! he had now changed his direction and was heading for a thick patch of larches only a short distance to his right, amongst which he would be lost to view for good. There was nothing for it but to try a shot, and I thought I had better fire at the foremost of the three stags, in the hope that the other two might turn back and come in my direction. I could not get quite a clear shot at the one I wanted, as he was moving among some scattered larches; but as he was only walking slowly, I got what I thought was a good sight on him, and taking rather full with the two hundred yards' leaf pulled the trigger. At the shot, the stag at which I had aimed made a great bound forwards; and I therefore knew he was hit, and hoped the wound would prove mortal. Then he disappeared amongst the thick larches, and the other two were also out of sight before I could fire again. We now took up the spoor; but to my bitter disappointment, although it soon led us into deep, soft, pure white snow, there was not a drop of blood to be seen, so I knew that my bullet had not touched his lungs. At the distance of about a mile, however, from where I had fired, we 
found just one drop of blood on the snow, but never another. Presently one of my hunters showed me where the wounded animal had eaten snow, and said he thought he must be hit in the stomach, and advised me to leave him to lie down and follow him up on the following day. This I resolved to do, as it was getting late, and we were some distance from camp.

On the following day we followed the wounded stag a long way, but had to give it up at last. So that chance of getting a fine maral head was lost by bad shooting. That my bullet touched the stag, there can be no doubt, as otherwise he would not have bounded forwards as he did when I fired, nor would there have been the single telltale drop of blood on the snow. He may have been struck in the body, for I was shooting with a .256-bore Mannlicher rifle, and these small-bored weapons often make a puncture from which no blood exudes. But I am rather inclined to think that I practically missed, my bullet only just cutting the stag across the top of the shoulders, for I was shooting with a rifle I was unaccustomed to and had never used before, and I found afterwards that it shot very high with the two hundred yards' sight. I trust I am right in this conjecture, as in that case the beautiful animal I fired at was practically uninjured, and is still roaming over the pine-clad slopes of his native mountains. These stags were not sufficiently near me to enable me to describe their antlers. What struck me was that their horns seemed very light in 
colour; but they looked long and heavy as well, and two of them, I believe, carried very fine heads.

This was the last chance I had, as, owing to the near approach of the feast of Bairam, I had to leave the mountains on February 26.

During this trip to the Murad Dagh, I saw scarcely any eagles or vultures, nor did I discover any of their nesting-places; so when Bairam was over I thought I would visit the Maimun Dagh, a mountain range much nearer the coast, where I knew these great birds of prey were plentiful, and where I was in hopes of getting a shot at a wild goat.

Leaving Smyrna, whither I had returned from Ouchak a few days before, at 8 A.m. on March 7, I arrived at Chardak, a station at the foot of the Maimun Dagh at five o'clock in the evening. Here I was joined on the following morning by my old friend Dr. Carpuzza, who had been with me on an expedition after wild goats, two years previously, and who had now come down from Dinair to meet me. After a hurried breakfast I sent Theodore and Mustapha, with the camp outfit packed in a native cart, to our old camping place at the foot of the mountain, and the Doctor and I then went straight up the hillside. In the course of the morning we saw two wild boars. They were not very large, and were probably a sow and a young boar. They were running when we saw them, and I got a snap-shot at the hindmost, as they were passing amongst some trees about one hundred and fifty yards 
off. The one I fired at turned short round and went back, the other one continuing its course up the mountain-side. I thought from this that I had hit him, but did not find any blood at the place where I had fired at him, and we could not follow the spoor very easily in the stony ground. Whilst still looking for it, we saw a large black vulture (Vultur cinereus) fly out from amongst some fir-trees not far below us, and going down to them soon discovered a large nest on the top of a high tree. I now left the spoor of the boar, which I had probably missed, and examined the tree which held the nest, as I was more anxious to secure some eggs of the black vulture than to shoot a small wild boar, whose head would not be worth keeping.

The tree was a large pine of great height, and looked more difficult of ascent than it probably would have done when I was a school-boy; but as Dr. Carpuzza was not of a figure for tree-climbing, I determined to try it, and at last, not without considerable difficulty, succeeded in reaching the nest. It was a huge structure which had probably been added to from year to year for a long time past, and was several feet in depth, as well as in diameter. It was composed of dry sticks and branches, many of them of large size, on the top of which was a hollow, lined with the comparatively soft bunches of green pine needles, adhering to thin branches, evidently lately broken off. The nest contained one egg, which was white in ground-colour, spotted and 
blotched with rich red brown. It proved to be a good deal incubated, and must have been laid towards the end of February. The black vulture is fairly numerous in Asia Minor, and is also found in Central and Southern Europe, being particularly plentiful in the great forests of Hungary. Their nests are always built in trees. They are solitary in their breeding habits, according to my observation, for, although there may be several pairs nesting on one mountain, the nests will be far apart.

During the next few days we spent our time, from daylight to dark, on the mountain looking for goats, and searching at the same time for the nests of vultures and eagles. We saw a few nanny-goats and kids almost every day, but not a single ram, and so never fired a shot. But if the hunting was a failure, the study of the bird-life on the mountain was most interesting, though none but the larger birds of prey had nested.

On March 9, I took my first griffon vulture's nest (Vultur fulvus), which I found placed on a ledge of rock in the face of a cliff high up the mountain. This nest was very easily accessible, and contained one egg slightly incubated. This egg was rather smaller than that of the black vulture, and pure white. I subsequently found many more griffon vultures' nests, which were always built of fir boughs, and rather neatly lined with the green ends. They were all, too, placed on the ledges of cliffs, and were many of them inaccessible without a rope, though I managed to take 
eight eggs in all. I never saw more than one in a nest, and they were all white, with one exception, which was marked all over with pale brown streaks, and was almost identical with the egg of a black vulture, which I subsequently obtained.

On May 9, I also visited the nest of a short-toed eagle (Circaëtus gallicus) built on the flat top of a high fir-tree from which I had taken one egg in I894. I found the bird on the nest, and when it flew off, could see with the glasses, from the rocks far above, that it had been sitting on two eggs. These eggs I took, and found them so much incubated that they were very near hatching. Like the one I took in I 894 , they must have been laid early in February.

On the night of March I I, a good deal of sleet and rain fell at our camp; and on going up the mountain the next morning, we found everything shrouded in thick mist. After ascending the mountain-side for about five hundred feet, we found the ground and all the fir and juniper trees thickly covered with snow. About nine o'clock the mist cleared off, and the mountain-side looked most beautiful, the foliage of every tree bearing a burden of light and feathery new-fallen snow. A black vulture, sitting on its nest on the top of a fir-tree, which was completely covered with snow, looked most curious. However, when the sun came out, the snow soon began to melt, and by the evening there was little left save on the highest parts of the 
mountain. Besides the nests of the short-toed eagle, and the griffon and black vultures, I also discovered the eyrie of a pair of lammergeiers (Gyps barbatus) high up on the face of a precipitous cliff. It was, however, quite inaccessible without a rope. After a few days, I began to get tired of the Maimun Dagh, as I could find no more eagles' nests, nor manage to come across a goat worth shooting; so I determined to visit the Ak Dagh before returning to Smyrna, as I knew it was a good place for the large birds of prey, and thought I might possibly get a stag there, too, though it was now getting so late in the season that I feared the older animals, that carried the best heads, would already have cast their horns.

On the afternoon of March I3, we went by train to Sutledj, and there procured a country cart to carry our things to a large farmhouse belonging to a Greek gentleman, who has rented a tract of land from the Turkish Government. At the time of our visit, the owner of the farm was absent in Smyrna, but we were most hospitably received by his bailiff.

On the following morning, after some delay, we succeeded in hiring pack-horses with which to proceed to the $\mathrm{Ak}$ Dagh, and in the afternoon got our tents pitched near a fine spring of water on one of the passes over the mountain. In the evening the weather turned very cold, and as there was very little firewood about, I found it difficult to keep warm.

The next morning broke cold and cloudy, and the 


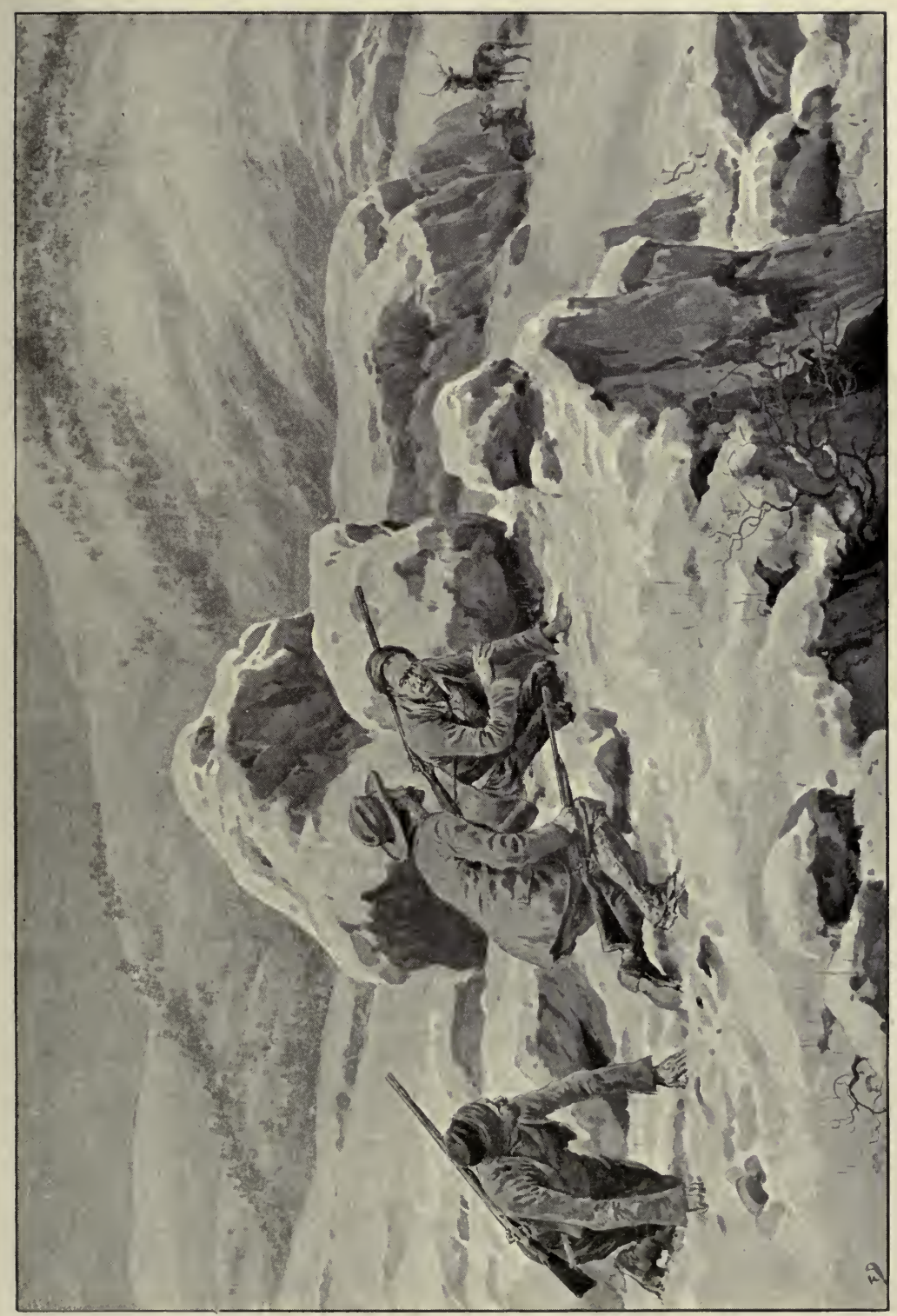

武

is

ठำ

됙

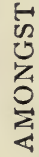

되

족

3

5

至

3

造

3

沗 

day was of the vilest for shooting, as the wind was blowing a perfect hurricane. However, as Achmet, the hunter I had engaged for this trip on the previous day, averred that he had heard from a shepherd that there were some deer on the hills to our right, I went out under his guidance to look for them, and it was not very long before we came on the tracks of two animals, whose hoof-marks looked so large on a piece of ground at the foot of a cliff which was free from snow, that I felt sure they were both big stags. I had, however, but little hope of shooting one of them, for the wind was blowing with such violence that I am sure I could not have hit an elephant at one hundred yards' distance, without a good firm rest for the rifle, and that is usually what you don't get just when you want it.

The tracks of the deer led us almost to the top of the hill we were on, where the snow lay at least three feet deep; and we came on them quite suddenly and unexpectedly, taking shelter from the wind behind some rocks. The one was lying on the snow just at the foot of a large boulder, and the other was standing near him. When we saw them we were amongst some rocks slightly above them, and behind one of these we immediately crouched. I then raised my head very cautiously, and examined the deer. They were not more than ninety or one hundred yards distant, and I could see very plainly that the one lying down had no horns; but I knew it was a stag, as I 
could distinguish quite distinctly the knobs on his head from which the horns had fallen. His companion had not yet shed his antlers, and as he stood, broadside on, they appeared larger than they really were. The wind was blowing in such a way that I found it most difficult to keep my rifle steady, even though I was resting it on a rock; and if I had had to fire off hand, I believe I should have missed the shot altogether, easy as it was. When I fired, both deer came plunging past us through the deep snow, and I tried to fire again at the stag with horns, but the wind was so strong I could not keep the sight on his body at all, and on seeing that he was throwing blood from his nostrils, gave up attempting to do so, as I knew that he was already as good as dead with a shot through the lungs. He soon rolled over; and the hornless stag, wondering what was the matter with him, halted and stood broadside on to us near his dying companion. His legs were buried in snow to the knees, and that perhaps made him look heavier in the body than he really was, but he certainly looked a monster; and I was so near him - for I had run forwards through the snow - that I could not only clearly see the knobs on his head from which a pair of mighty antlers could but very recently have fallen, but could even distinguish the black patch on his under lip. After standing motionless for a few moments, he turned and plunged heavily through the snow down the hillside. 


\section{SPORT AND TRAVEL}

Had I met with this stag a fortnight earlier, I should probably have secured a very fine head. The one I had killed proved to be a fine young stag, but with comparatively poor horns, as he was only a nine-pointer, and had moreover broken the second and third tines on the one side, probably in battling with heavier stags during the last rutting season He was in pretty good condition, and his meat I found, if not very excellent, at any rate, fairly good eating. I had to skin and cut him up almost entirely by myself, as Achmet's hands and feet were so numbed by the cold wind that he could give me very little assistance, but had to run about to keep himself warm. When I had finished my task, we buried the meat under the snow, and then trudged back to camp, Achmet carrying the head. Soon after we reached the tents the clouds closed in on us, and a heavy storm of snow and sleet began to fall. Shortly after dark some wolves commenced to howl on the hillside opposite, and presently came down close to our camp. These animals, Achmet told me, annually commit great havoc amongst the sheep, and in severe winters collect in packs and attack human beings. During the winter of I895-96, which was a remarkably cold one, eight people, he informed me, were killed and eaten by wolves near a mountain village not far away.

On awaking the next morning, I found the ground round the tents and the flaps of the tents themselves 
covered with snow, which, however, soon began to melt when the sun came out. I sent Achmet with two other men and a pack horse for the meat of the deer, and then went for an ornithological ramble with Dr. Carpuzza, but though we found three griffon vultures' nests, they were all in places we could not reach.

On the following day I went with Achmet up the mountain to the left of our camp. The snow lay very deep (usually about five feet when probed with a stick), but we never sank in it above the knees, and there was often a crust which bore us. On this day, I found an eagle's nest, built in the mouth of a small cave, half-way up the face of a precipice. I got a view of the bird as she flew off the nest. She was very dark-coloured in body and tail, with head and neck greyish, and I identified her as a golden eagle. I then climbed some rocks opposite the cliff on which the nest was built, and saw with my glasses that there were two eggs in it. These eggs I was determined to have, though I saw at once they were not to be taken without a rope. So I returned to camp, and sent Mustapha down to a large village below the pass to buy ropes, and also to bring men and pack animals to shift our camp.

On Thursday, March I8, Mustapha returned with the pack ponies and their drivers and about three hundred feet of strong native rope, and we then all proceeded to the cliff where the eagle's nest was situated. This 


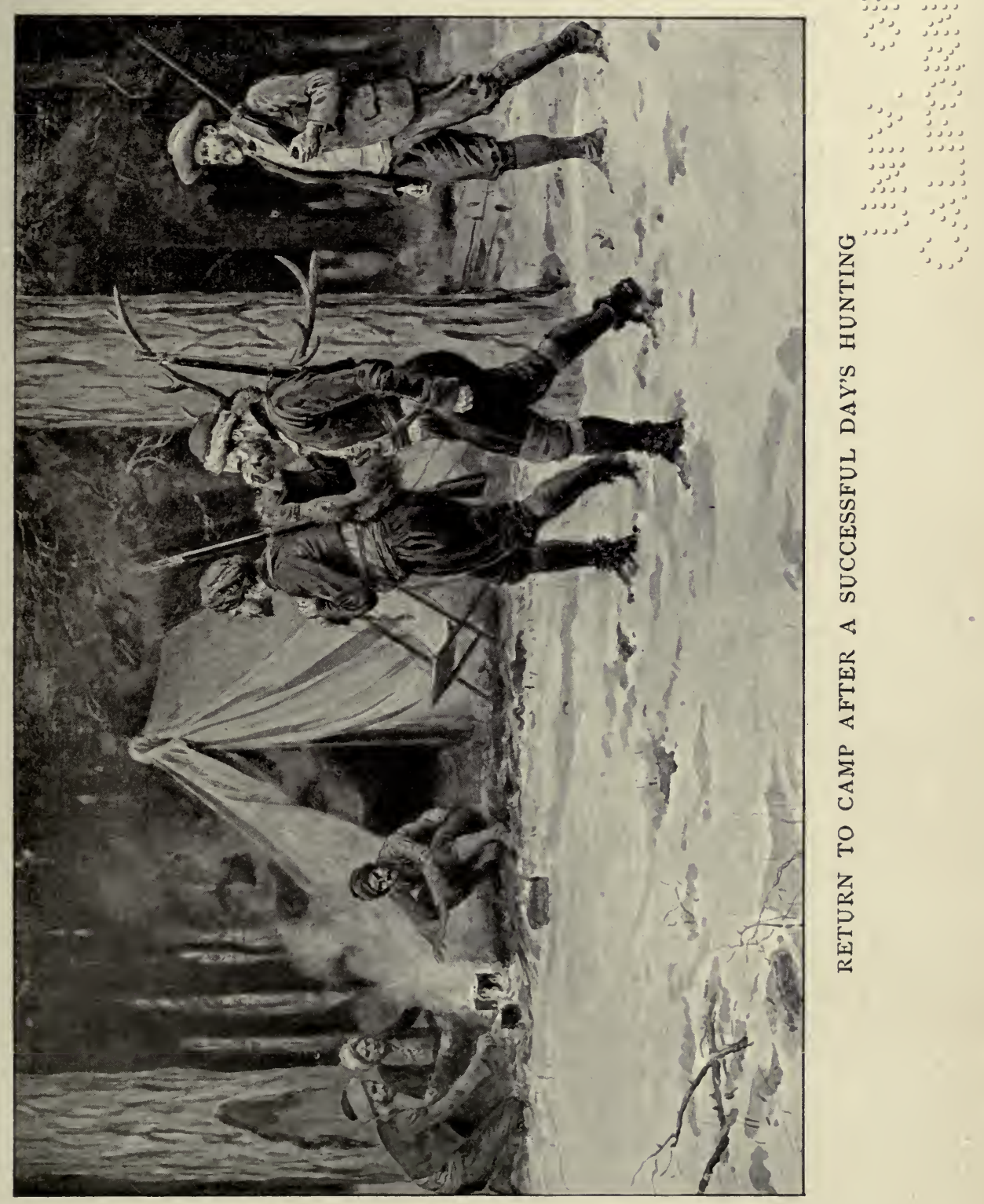



cliff was quite perpendicular, and, I should judge, about one hundred and fifty feet high, and the nest was situated at a height of about sixty feet from the ground. I first twisted the three hundred feet of half-inch cord into a strong rope of less than half that length, and also made a light but strong rope ladder out of the ropes from the pack saddles. I then sent four men to the top of the cliff with the long rope, which they let over the precipice directly over the eagle's nest. The rope ladder was then attached to the end of it, and drawn right over the opening where the nest was situated, and this was held in its place by another rope tied to a tree at the bottom of the cliff. Whilst we were adjusting the rope ladder, one of the Turks who had come up with the pack ponies asked Dr. Carpuzza why I had taken the trouble to make the rope ladder, and said the rope alone was all he himself would require to enable him to take the eagle's eggs. On this being interpreted to me, I said to the man, "Very well, then, you may go up and take them for me, as you will now be able to go up by the ladder like a king." $\mathrm{He}$ at once kicked off his shoes, and commenced to climb up the rock with the help of the rope to the ladder. But when he reached it he did not like the way in which it gave to his weight, owing to the stretching of the long rope, and so came down again, looking very sheepish and crestfallen.

There was now really no difficulty in getting up to the nest, and no danger, as long as the rope held, 
though of course the sensation of being dangled at the end of a long rope is not a pleasant one till one gets accustomed to it. As no one else volunteered to go up, I was just taking off my boots to go myself, when Mustapha came from the top of the cliff where he had been superintending the securing of the rope, and asked me to allow him to get the eggs for me. This I was graciously pleased to permit him to do, for I have got to that time of life when a man does not care about climbing a high tree or a steep cliff, if he can get anyone to do it for him. Mustapha reached the nest without difficulty and brought down the two eggs in his handkerchief, which he held in his teeth as he came down the rope ladder. Whilst he was robbing the nest I photographed him from the rocks opposite. Of the two eggs, one was quite white in ground-colour, with a few flecks of dark brown sprinkled sparsely over it, whilst the groundcolour of the other was pinkish brown with darker shades of the same sort of colour, producing a beautiful marbled appearance. The white egg must have been laid first, as it was just very slightly incubated, whilst the mottled egg was absolutely fresh and must have been laid only a day or two before we found the nest. After being disturbed on the previous day, the bird seems to have deserted her nest, as she did not return to it all that day,-Dr. Carpuzza watched for her until dark, - nor was she there early on the morning when we took the eggs, which we found to 


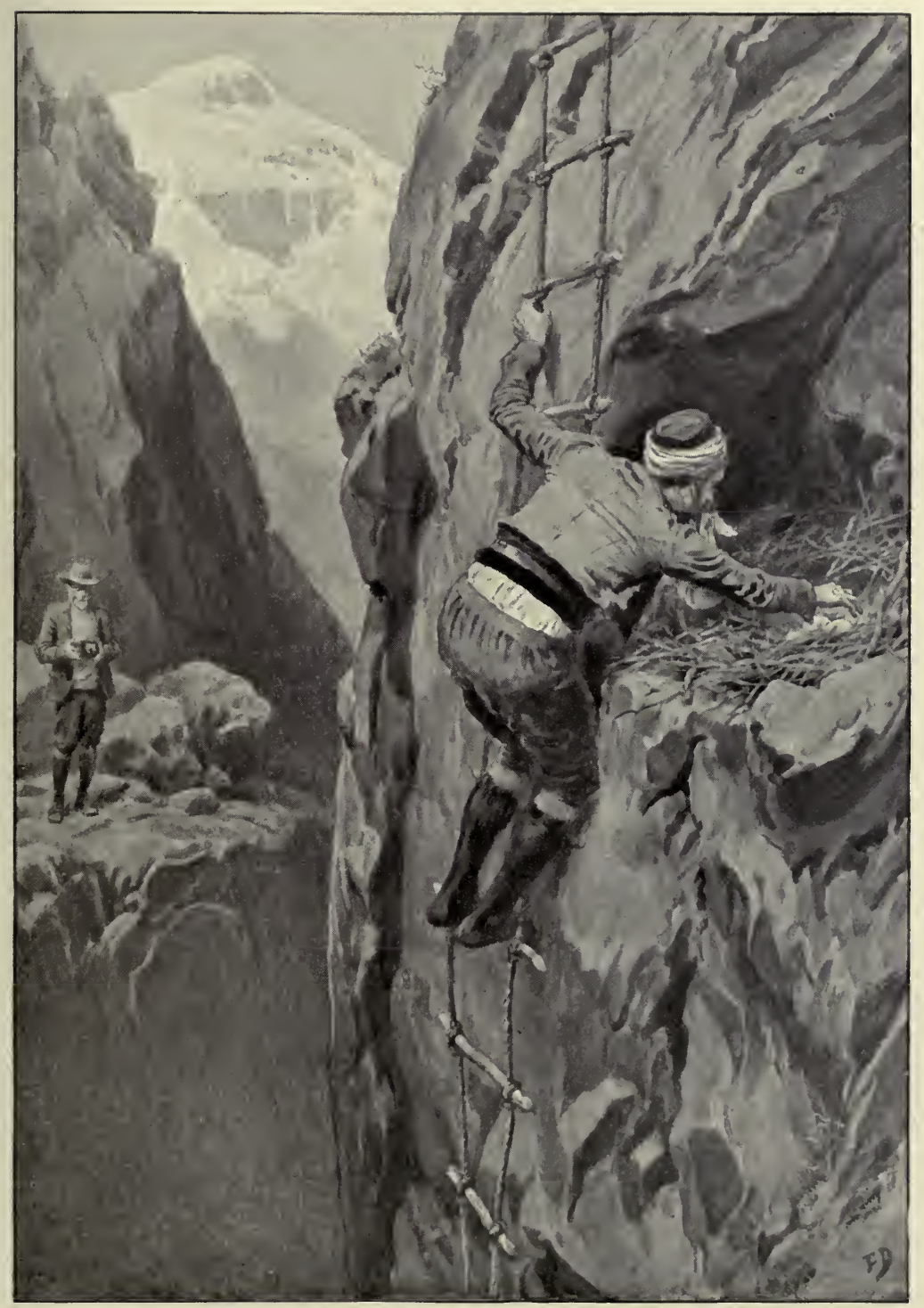

WHILST MUSTAPHA WAS ROBBING THE EAGLE'S NEST, I PHOTOGRAPHED HIM FROM THE ROCKS OPPOSITE 

be ice cold, for there had been a hard frost during the night.

After having successfully negotiated the eagle's nest, we packed up and moved camp farther round the mountain to a place called Shaputlu; but finding no signs of deer, or anything of interest in this neighbourhood, I packed up again on March 20 and sent my camp outfit in charge of Dr. Carpuzza to the other side of the mountain. Then with Achmet I went over the mountain, rejoining the pack train late in the afternoon. During our long tramp in the snow we did not see even the track of a deer. As I had intended to stop a week in this camp, we sent our pack horses off to the nearest village at the foot of the hills as soon as they were unloaded, and then set to work to get our tents up, as bad weather threatened.

We had pitched our camp in an open meadow between two little streams of water, but just beneath a slope of the mountain covered with pine forest. Below us the ground was free from snow, but it lay in deep banks just above us. We had only just got the tents up when heavy showers of sleety rain commenced to fall and continued to do so without cessation, all through the night. Just as day was breaking the next morning, this sleety rain changed to snow, which came down so thickly that the meadow below us, which yesterday had looked like a beautiful carpet, so varied in colour were the little crocuses that were everywhere shooting up amongst the short grass, was 
soon covered with a wintry white sheet several inches deep, and we had to keep continually shaking and scraping the fast accumulating snow from the tents. At ten o'clock it was still snowing hard, and it really looked as if it never meant to stop doing so any more.

The Turks and Dr. Carpuzza now began to get anxious, and advised me to send immediately. for the horses to carry our baggage down the mountain before the paths became impassable; and as I could do nothing whilst the snowstorm lasted, and they thought it might continue for three or four days, I took their advice and sent for the horses, which reached our camp in the afternoon. It was still snowing hard, and the snow by this time lay about a foot deep on the open meadow-land round our tents; but we lost no time in getting the packs on the horses, and reached the village of Mendes at the foot of the mountain by six in the evening. About half-way down, the snow changed to rain, and having no waterproofs we got very wet before reaching the village. We rented a peasant's house or two-storied $\log$ hut for the night, and buying a good supply of wood soon had a brisk fire burning on the large hearth, before which we proceeded to dry our things.

During the night it must have turned colder, as when we woke in the morning the whole village and the surrounding country were covered with snow. A perfect hurricane, too, had sprung up, which, tearing the new-fallen snow from the ground, carried 
it upwards again in fine powder. In all my life I have never seen a fouler day. Hoping for an improvement, we remained in the village till after breakfast, but finding that the storm was growing worse, I resolved to push on and get out of the mountain whilst it was still possible to do so, so we packed up and started at 10.30; but the storm grew worse and worse until the wind had increased to a veritable hurricane. Luckily it blew from directly behind us, otherwise it would have been impossible to face it. The whole atmosphere became a snow fog, composed, not only of the flakes coming down from the clouds, but also of the finer particles torn up from the ground by the violence of the wind.

Had we remained at our camping place on the mountain, our tents would inevitably have been blown down, and we should have had to abandon our baggage and get out of the mountain the best way we could. I am not at all sure that we should have been successful in doing so, for in such a snowstorm, and with such a wind blowing, one could well imagine that it would be easy enough to lose one's way and perish amongst the deep snowdrifts of the higher mountains. It was bad enough getting along on the lower level where we were. In some places we had to plough through snowdrifts four feet deep, but luckily these were never of great length, as for the most part the snow lay but thinly on the bare track we were following, having been torn off it by the wind, and 
hurled against the rocks and bushes on either side of the path. My hair between my hat and the nape of my neck soon became a lump of ice, and Dr. Carpuzza suffered the same inconvenience which Theodore and the Turks escaped, as they wore long cloaks with hoods.

After four hours' struggle, we reached the village of Homa. Here we were below the snow-line, but it was still sleeting, the sleet melting as it fell to the ground. From Homa, another hour's walking brought us to the Greek farmhouse where we had passed the night on our way to the Ak Dagh. The storm had now lasted for forty-eight hours, and still showed no signs of abating. The farmhouse in which we had taken shelter shook and rattled again under the violent assaults of the wind, and a great deal of plaster was shaken or torn from its walls, whilst all the tiles were blown off the roof of an outhouse. Just above the village of Homa, there were some high cliffs, on the ledges of which, the Turks had told me, two pairs of eagles were nesting, as well as numbers of griffon vultures. Of these latter, they said there were at least one hundred nests. I was loath to leave the district without visiting these cliffs, but the badness of the weather made it very difficult to do so. All night long the gale continued, and on the following morning the wind was as strong as ever, and Mustapha said it would be impossible to climb up the cliffs. However, I determined to try what could be done, and so 
walked back to Homa in the teeth of the wind, accompanied by Dr Carpuzza, Mustapha, and another Turk carrying the rope I had previously bought in order to reach the nest of the golden eagle.

Arrived at Homa, we with some difficulty got a man, who said he knew where the eagles had their nests, in caves high up on the cliffs above the village. These caves we reached after a stiff climb, but with comparative ease, as the wind would have made it impossible to have attempted to pass over any really dangerous ground. On our approach, several griffon vultures flew out from the recesses of the large caves, but though we found several of their nests, only one contained an egg. After this, we visited other caves, but found no more nests, nor did we see any sign of the eagles, the hope of finding whose eggs had been my principal inducement to brave the fury of the storm. As a matter of fact, I don't believe there were any eagles breeding above Homa, the Turks not being able to discriminate between these birds and the more numerous vultures. It was still early when we got back to the farmhouse, so we went on the same evening to the station of Sutledj on the Aidin railway. I may mention that on crossing the plain to Homa in the morning the wind sometimes blew with such force that it actually brought us to a standstill, and whilst these gusts lasted, one could lean against it like a wall.

As I wished to revisit the Maimun Dagh before returning to Smyrna, in order to take two black vul- 
tures' nests that I had previously found, but had not been able to reach without a rope, we took the early train to Appa, on the morning of March 24; and then, sending on Theodore with the baggage to our old camp, the Doctor and I climbed into the mountain, but did not visit the vultures' nests, which were on the spurs immediately above Chardak. We, however, found the nesting-place of a pair of peregrine falcons, though it was too early in the season to hope to get their eggs. In the afternoon, too, we saw great numbers of buzzards, flying about the mountain-side in flocks of twenty or thirty. At one time there were quite one hundred of these fine birds in sight at once. They were, I fancy, rough-legged buzzards (Aquila lagopus) on migration from their winter-quarters in the tropics to their far off nesting-places in Northern Europe. The cranes, too (Grus communis) were now very noisy, and their loud trumpeting cry was continually to be heard from the marshy ground on the edge of the great salt lake in the plain below the mountain. The natives say these birds remain here the whole year round and breed in the marsh, but at the date of my visit they were always to be seen still feeding in flocks, and did not yet seem to have paired.

The following day, March 25, was my last on the mountain, and was a very satisfactory one, as with the help of the rope, I took three griffon vultures' nests and two black vultures', each nest containing one egg. I may mention that all the griffon vultures' nests 
I examined, appeared to have been freshly built that year, and were certainly all freshly lined with the ends of small fir branches, the bunches of green pine needles on which formed a soft cushion for the single white egg. Although these nests were large, they were small in comparison with the accumulated piles of many years from which I took the eggs of the black vultures. The eggs of the griffon vulture had a musky smell when first taken, from which those of the black vulture were entirely free.

I also saw two nanny-goats, and shot one to take down with me to Smyrna. I saw too, for the first time, a pair of ruddy shelducks (Casarca rutila), one of which in the early morning kept flying along the mountain-side and perching on the rocks above our camp. Later in the day, I saw both of them feeding in the marsh near the cranes. On my way back to Smyrna, I noticed many wheatears and wagtails about, none of which were to be seen earlier in the season. The storks, too, were now all back at their nests. These interesting birds breed very plentifully in Asia Minor, and their nests may be seen on the houses or trees in every town and village. At Ephesus they are particularly numerous, and every pillar of the old Roman aqueduct has been utilised as a nesting site. On March IO, I had seen two great flights of these birds passing over the Maimun Dagh, and the sight of them conjured up visions of the far off land in which I had spent all the best 


\section{SPORT AND TRAVEL}

years of my life, for I thought they might possibly have come all the way from Southern Africa, since year after year I had seen large numbers of storks appear in Matabeleland, and even farther south, during January and February, when the rainy season was at its height and frogs were plentiful.

With my return to Smyrna, 'my six weeks' wanderings in a wild and interesting country came to an end, but it will be long before the vision of the snowcovered mountains, grand and beautiful, alike both in sunshine and storm, fades from my memory; and in my dreams, I often still pursue the great grey stags in those wild solitudes, and sometimes stand exultant beside the fresh-slain form of a mighty antlered monarch of the mountains, a very giant of his kind. Will that vision always be a dream? Time alone can tell; but time is against me, as it is against all whose best days are past. 
"NOTES ON A LATTER-DAY HUNTING TRIP IN THE ROCKY MOUNTAINS"

S a boy I used to devour ravenously the 1works of Ballantyne, Mayne Reid, Catlin, and 1 other writers of fact and fiction concerning the wonders of the great continent of North America, and from that time onwards had always nourished a strong desire to visit that country.

But it was not civilized America that I wished to see, nor the works of civilized man in that part of the world, since to me all cities built by peoples of the Caucasian race seem very much alike, although they may differ one from another somewhat in details. They are, however, all of the same genus, so to speak, and to my mind hold nothing so grand or beautiful within their dingy walls as the ever-varying aspects of nature in the wilds. Hotels perched high up amongst the Swiss Alps, railways through the Rocky Mountains, or steamboats on the Zambesi are all very good and useful things, no doubt, but they destroy the poetry of their surroundings.

The America I desired to visit was the America of my boyish dreams, the land of vast rolling plains, over which the shaggy bisons - now, alas! extinct - 
once ranged in such countless multitudes, and of rugged mountain ranges where the wapiti, once so. plentiful, still roams warily, never now showing his magnificently antlered head beyond the shadow of the dark pine forests, if he can possibly avoid doing so. In a word, I wished to see wild America if there was any left, not the new Europe of the Eastern States.

In I893 I came very near the realisation of my dream, for I had actually booked my passage to New York and was passing through London on my way to join the steamer, when judging from a cablegram in one of the daily papers that trouble was surely brewing between the Matabele natives and the settlers in Mashonaland, I hurriedly changed my plans and embarked for the Cape instead.

From that time till 1897 circumstances kept me in the Old World, but in that year I was able, in company with my wife, to join a friend who owns a cattle ranch in Wyoming, in an expedition to the Rocky Mountains. September I having been appointed as the day on which we were to start from the ranch on our hunting trip, my wife and I were able to accept an invitation which had been extended to us to be present at the meeting of the British Association which was held in Toronto during August of the same year. We crossed from Liverpool to Montreal early in that month, in the good ship "Parisian" of the Allan line, but being anxious to get to the Rocky 
Mountains as early as possible in September, our stay in Canada was necessarily brief. During our short visit, however, we made many friends and saw enough of the country and its most kind and hospitable inhabitants to make us determine to revisit it whenever circumstances should permit us to do so.

Leaving Toronto on August 25, and travelling via Chicago, - the infant Hercules of the great cities of the world, - we reached Sheridan, Wyoming, on August 29, and were driven out the same afternoon to our friends' ranch near the little town of Bighorn. During the drive we saw numbers of the so-called "prairie dogs" (Cynomys ludovicianus) and quite a dozen of the quaint and solemn little burrowing owls (Speotyto cunicularis) which live and nest in their burrows. These latter were always sitting just at the mouth of one of the prairie dogs' holes. Just before reaching Bighorn we passed a beaver dam. There are several colonies of beavers in this neighbourhood; but these animals would probably have long since ceased to exist in this part of America, had they not been protected by the Government of the State of Wyoming. This protection may possibly not be extended to the beavers very much longer, as they cause a good deal of trouble and expense to the farmers through whose land the stream on which they live happens to run, by damming it in such a way as to interfere very materially with the necessary work of irrigation. 
On the day following our arrival at our friends' ranch we packed all the various things necessary for our trip on to a light waggon, which we were to take with us as far as the foot of the main range of the Rocky Mountains, whence we intended to proceed to

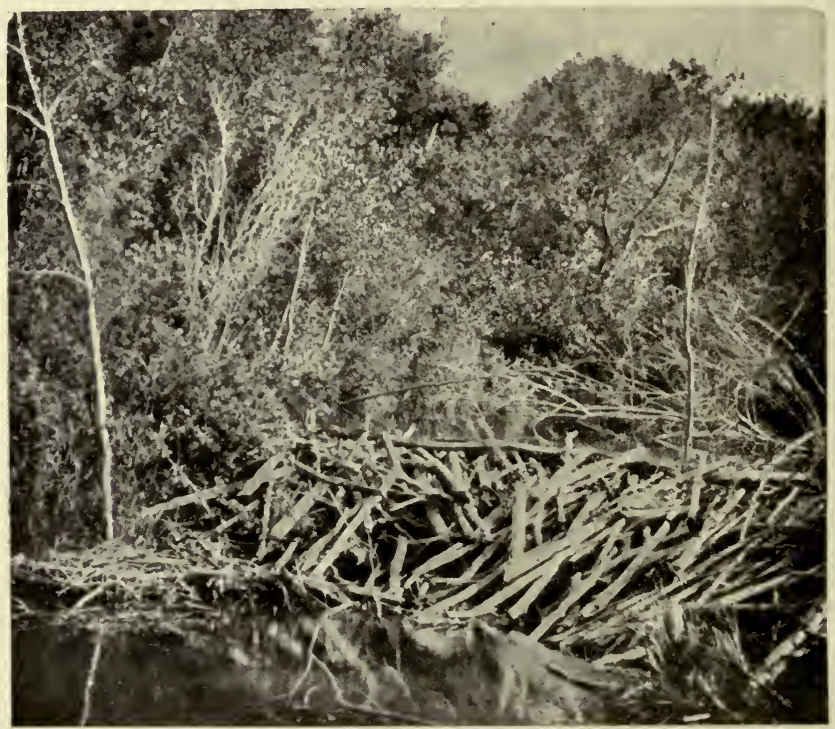

Beaver Dam on Duck Creek, near Bighorn, Wyoming, AUgust, 1897

our camping-ground with pack ponies. In the afternoon I rode about two miles up the creek to examine a very perfect specimen of a beaver dam. This dam I was told was a very typical one. It was built across a little valley some thirty yards in width, in the form of a crescent. The stream, which had originally been confined to a narrow channel not more than a few 


\section{SPORT AND TRAVEL}

yards in width, had, together with the overflow of the water, been completely dammed and a little lake formed which extended right across the valley. In this little lake stood many dead and leafless cottonwood or quaking aspen trees, which, having originally stood on dry ground, had been killed by long immersion in the water. The water of the lake was flush with the top of the dam, over which it ran in the centre, and gradually found its way back to the original bed of the stream.

I was told that there were probably about twenty beavers in this colony, and the amount of work they had accomplished in building the dam I have described was really astonishing. They had been very busy the night before my visit, and had cut down a number of saplings of a soft-wooded tree something like poplar. The largest sapling I saw which had been felled was about four inches in diameter. No doubt beavers could cut down much larger trees if they wished to do so, as they seem to be able to fell small saplings with three or four cuts of their sharp and powerful chisel-shaped teeth. ${ }^{1} \quad$ The beavers here build no lodges on their dams, but live in holes in the banks of the stream they have dammed. They are now entirely nocturnal in their habits, neither feeding nor working between sunrise and sunset.

On the first of September we made a start for the

1 At Leonardslee in Sussex, the seat of Sir Edmund Loder, Bart., the acclimatised beavers have cut down several very large trees, amongst them an oak-tree, eighteen inches in diameter. 
mountains, getting under way at eight A.M. Our party consisted of my wife and myself, our friend W. M., Bob Graham our guide, Milligan the cook, and Webster, who drove the waggon and later on helped to pack the ponies and assist in all camp work. A few days later we picked up another young fellow rejoicing in the name of Jinks, whom Graham had previously engaged, in order that W. M. and myself might always have someone to accompany us when hunting. Our goods and chattels were all packed on the waggon, which was drawn by four strong horses. Everyone but Webster rode, and our eleven pack ponies were driven loose behind the waggon. We followed a very good road that had been made two years previously across the Bighorn range to the broad valley, or basin, - as it is called out West, lying beyond, and which extends to the foot of the main chain of the Rocky Mountains. By midday we had reached the summit of the first ridge of the Bighorn range, seventy-two hundred feet above sea level. From this point we obtained a fine view of Cloud Peak, the loftiest mountain in the Bighorn range, which is upwards of sixteen thousand feet high.

Twenty years ago the country through which we were now journeying simply teemed with game, wapiti, mule deer, and wild sheep being very abundant in the mountains themselves, whilst white-tailed deer were plentiful in the cottonwood bottoms at the foot of the hills, and bison and antelope ranged 
in great numbers over the plains beyond. One of the first settlers in this part of the country, whose ranch in the early seventies was situated not far from the present town of Bighorn, told me that on the rare occasions when strangers visited him he used to ask them what meat they would like for dinner, giving them the choice of wapiti, mule deer, white-tailed deer, wild sheep, antelope, or bison; and said that if they chose anything but the last named, he was nearly always able to go out and get it within six hours. The bison, although they were sometimes to be seen in thousands close to his cabin, were not always to be depended on, as they changed their range according to the season of the year, wandering all over the vast plains of the West in search of the best grass. Bears, too, at that time were so plentiful, my informant told me, that he could not keep them out of his kitchen-garden, which they were in the habit of visiting almost nightly.

But what a change has come over the country in twenty years! There are still a few wapiti, mule deer, and wild sheep left in the Bighorn range, but very, very few, Graham told me, even compared to what there used to be so lately as five years ago, the sheep being now almost entirely confined to the neighbourhood of Cloud Peak. Of the white-tailed deer, once so numerous in all the valleys below the hills, there are now none left anywhere near the town of Bighorn. The bison, too, have long since disappeared from the neighbouring plains, whilst the ante- 
lope have become very scarce and terribly wild. Of bears there are still a few left, but these have become so timid and so cunning that they are but seldom encountered.

Curiously enough, my friend W. M. shot a most magnificent wapiti bull in the hills close above his ranch in August, I896. This splendid animal carried one of the most beautiful heads that has ever yet fallen to the rifle of a hunter. It may be a few inches shorter than the longest head known, but for symmetry and shapeliness, and every point that goes to make a deer head a beautiful thing to look at, I have never seen its equal. This beautiful head has been photographed, but no photograph can do it anything like justice; it must be seen to be thoroughly appreciated. Of course, it was an extraordinary piece of luck getting this wapiti, as none of his kind has been seen for years previously anywhere near the place where he was shot, where indeed hunting had practically ceased for lack of game. This old fellow must have returned to his former haunts after the previous rutting season, and having wintered comfortably had probably never wandered far from the spot where he was finally shot, for the grass was there very strong and rich, which had enabled him to get into splendid condition and grow a singularly large and beautiful pair of horns by the time my friend at last spied him with his glass from a point of rock quite close to the road. 
In the afternoon we continued our journey through mountains for the most part covered with pine forests, much of which had been terribly devastated by fires. In some places acres upon acres of tall grey-stemmed dead pine-trees were still standing, whilst in others

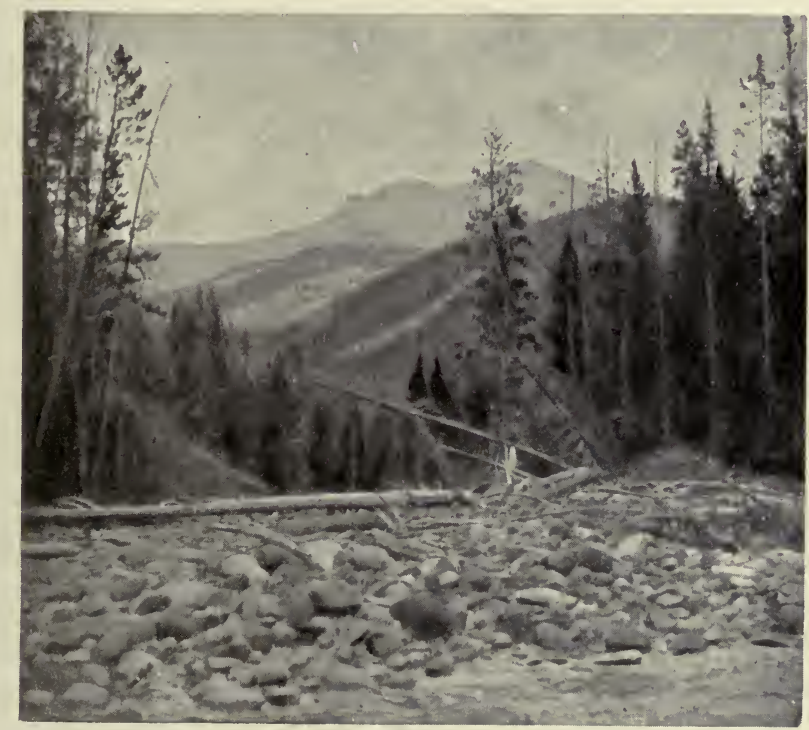

View in the Bighorn Mountains, Wyoming, September, i897

hundreds of these dead stems had been blown down by the wind and lay one across another in hopeless confusion. Here and there young trees were growing up amongst the dead and decaying stems, but as a rule there appeared to be no new growth in the devastated areas. As we proceeded we gradually ascended and camped in a beautiful little open glade, close to a 
stream of clear cold water, seventy-eight hundred feet above sea level. The night was bright and clear and much warmer than I should have expected at such an altitude, there being no sign of frost in the morning.

On the following day we were up at $5 \cdot 30$, breakfasted at six, and then packed the waggon and got off at 7.45. Before we broke camp several camp robbers (Perisoreus canadensis), birds of a species allied, I think, to the European jay, came hopping round us, picking up the scraps of food that had fallen to the ground during breakfast. These pretty birds are most friendly and confiding in their behaviour; and as soon as they find that their confidence has not been misplaced, they become extraordinarily tame, and I should think might soon be coaxed into taking food from one's hand. Wherever we camped in the mountains we always had at least one pair of these cheery little robbers living with us, and freely forgave them their petty larcenies for the sake of their pretty, sprightly ways and pleasant companionship.

The road this morning led us through rocky, forestclad hills whose summits were bare, as they rose above timber line (here probably between ten thousand and eleven thousand feet above sea level). Our route lay up and down hill, but we gradually rose to a height of ninety-three hundred feet. Here we struck the upper creeks of the Tongue River, and outspanned for our midday meal and rest.

The country about here seemed admirably suited 
to the requirements of all the various species of big game which not many years ago used to abound in these mountains, but we never saw a track of any kind, old or new, and Graham did not seem to think that there was a single deer left anywhere near the road. We saw, however, numbers of the beautiful little striped squirrels called chipmunks (Tamias striatus). These little creatures were very tame and often allowed us to approach to within a few yards of them. Larger reddish-grey squirrels (Sciurus hudsonius), very similar to our English animal, were also common and sometimes extraordinarily tame. Of birds I saw but few in these mountains, but I noticed a pair of American water ouzels (Cinclus mexicanus) on one of the mountain streams we crossed, which except in colour appeared just like our English bird, as they flitted from stone to stone or stood bobbing up and down on the rocks. These American birds were of a uniform slaty-blue colour. In the pine forests the camp robbers were common, as well as a species of tit (Parus gambelli?) and a handsome black and white woodpecker with (in the male) a bright red head, but altogether bird-life was very badly represented. Birds of prey seemed entirely absent, and I did not notice either a hawk or an eagle of any kind whilst crossing the Bighorn range.

During the afternoon we crossed the main divide of the Bighorn Mountains at an altitude of ninetysix hundred feet, rocky ridges rising about one thou- 
sand feet on either side of us, bare of timber and very rugged in aspect. From the divide we descended rapidly for sixteen hundred feet and camped on Shell Creek at a height of eight thousand feet above sea level. This evening we bivouacked in a little open glade surrounded by mountains and pine forests; and although there appeared to be absolutely no game about, yet the air was so invigorating and the surrounding country so wild and beautiful that it was impossible not to feel a happy contentment of mind, - a contentment which did not, however, last long, for we had scarcely unhitched our team when a travelling party going eastwards appeared and pitched their camp not far from ours.

I had just finished putting up the tent which my wife and I occupied, when a member of this party who had first got his bearings from one of our men - walked up and said: "I believe you are Mr. S. You 've travelled some in Africa, I'm told. I'm Mr. _ of the 'Chicago _ ; ' here 's my card. You must have met with some interesting experiences during your travels; perhaps you would n't mind, etc." Now, well as I know all the great and endearing qualities of the modern newspaper reporter, - the talented artist who can always make so much out of so little, I confess to having felt annoyed at meeting a member of the craft in the wilds of the Bighorn Mountains. His presence there seemed altogether incongruous and out of harmony with the surroundings. However, Mr. 
of the "Chicago __ " proved to be a very good sort, in spite of his professional zeal, and we spent a pleasant evening together, during which I think he gave us more information concerning his own country than he received about Africa, for he had just returned from a

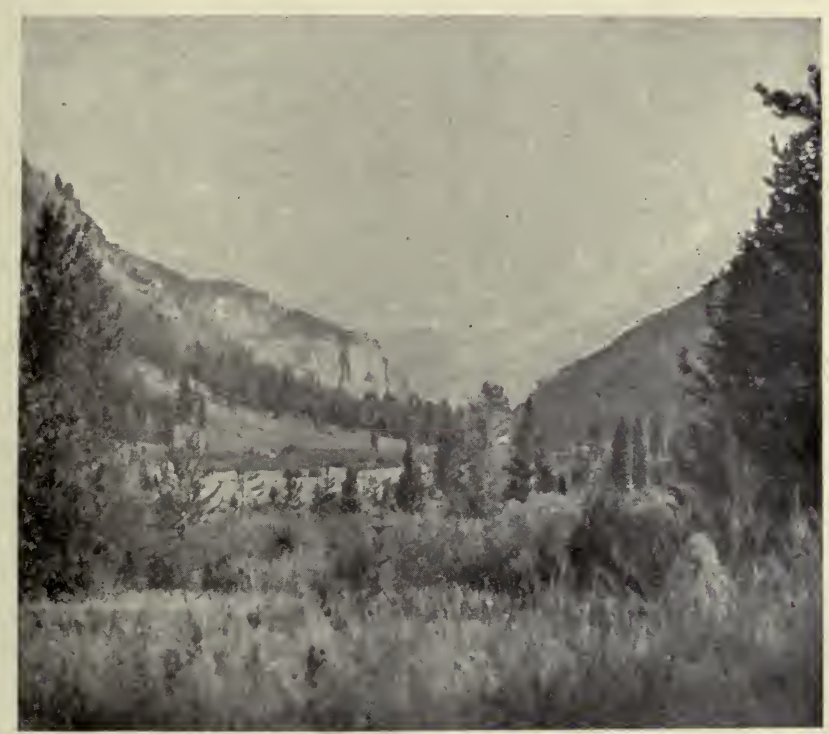

Scene in the Bighorn Mountains, September, I897

three months' trip to the Rocky Mountains, during which he had visited the Yellowstone Park, in order to write an account of its wonders for his paper.

On the following day we continued our journey westwards, crossing another high ridge ninety-two hundred feet above sea level. The country through which we passed during the day was for the most part 
open and grassy, but as we were still high above the plains of the Bighorn. Basin, I was rather surprised when Graham pointed out to me a bleached bison skull. We soon, however, came across several more, one of them with the horn still on the one core, and we also saw an old trail and several wallows once used by these animals. I may here say that all over the Bighorn Basin and along the foot-hills of the Rocky Mountains I subsequently found numbers of bison skulls in a perfect state of preservation, many of them with the horns still on the cores, and several with portions of the skin of the head and neck (with the hair still on it) adhering to the bone. Now, I believe that the last bisons seen alive in this part of America were killed in I884, therefore none of the skulls which I saw could have been lying on the ground, exposed to all the disintegrating influences of summer sun and winter frost for less than fourteen years. I should certainly never have believed that even the hardest of bone, let alone horn and skin, could have withstood the ravages of time and exposure so well. In the climate of Africa no organic matter lasts very long when exposed to the weather, and even the skull and leg bones of an elephant would, I think, crumble to dust and absolutely disappear in less than fifteen years from the date of the animal's death.

As we advanced towards the Bighorn Basin, the pine forests completely disappeared and the country gradually became more and more sterile. The cast 
horns of wapiti and mule deer - the former very much preponderating in numbers - now too lay scattered everywhere over the face of the country. These horns were all bleached white, though most of them were quite perfect and showed no signs of having been gnawed by hinds or rats. They had all been shed years ago during the annual migrations, when the great bands of wapiti were returning in the spring from their winter feeding-grounds in the Bighorn Basin to the mountain forests where they lived until once more driven to the lower and more open ground by heavy snow.storms. Now no more wapiti winter in the Bighorn Basin. Their place has been taken by the settlers' stock; and the wild creatures which the sheep and cattle have supplanted - the very few that still exist in this once magnificent hunting-ground - have to pass the whole year as best they can amongst the mountains.

In the afternoon our route lay along the course of Trapper's Creek, - a mountain torrent which has cut for itself a deep gorge or canyon of very remarkable appearance and over one thousand feet in depth. Wild sheep, I was told, were not long ago plentiful amongst the precipitous rock walls, interspersed with steep grass slopes, of this wild gorge, but I doubt if any are left there now. Just before dusk we reached Trapper's Creek below the mouth of the canyon, and on the following day, September 4, we followed the course of this stream to its junction with Shell Creek, 
and then travelled along the course of the latter to the point where it enters the Bighorn River. The latter is a fine stream, from one hundred to two hundred yards in width where we forded it. We here saw a flock of wild geese, standing on a sand-bank, but they were very wild, and we could not get within rifle-shot of them, nor do I know to what species they belonged. In the afternoon our route lay for a short distance along the Bighorn River, and then westwards up the course of one of its tributaries called Grey Bull Creek, which has its source in the Rocky Mountains. In the evening we camped on the bank of this creek at a spot where the water had ceased to run. There were, however, numerous pools in the bed of the creek, but the water was not very palatable, being strongly impregnated with alkaline salts.

During the two following days we travelled steadily westwards across the Bighorn Basin. The heat was very great, the dust very annoying, and the water very bad. The whole of the Bighorn Basin is a most uninviting country to look at, being arid and barren to an indescribable degree. During summer the heat is very trying, and in the winter the treeless plains are swept by icy winds. Except along the river bottoms there is scarcely any vegetation whatever save the ever-present sage bushes. In general appearance this district of America very much resembles the driest and most arid portions of the Karroo in the western province of the Cape Colony; whilst some 
of the bare ridges or low ranges of hills by which it is intersected look like gigantic heaps of tailings from diamond or gold mines. The faces of these mud ridges have been worn by rain and snow and sun and storm into innumerable grooves and furrows, and in some places the soil is very beautifully coloured with various shades of red, pink, and mauve, the colours being possibly due to the alkaline salts with which the whole district is more or less impregnated.

But although the basin of the Bighorn is in general aspect an arid and uninviting-looking desert, it is - thanks to the fact that it is surrounded by high ranges of mountains - intersected by several fine streams of water, by the aid of which considerable areas of ground have been put under irrigation by the hard-working and intelligent settlers who have taken up land in this district. The land bordering the streams is usually very level, and there is not much difficulty in leading the water on to it. Only hard work and ordinary intelligence are required. I saw excellent crops of wheat and oats standing where the whole country but a few years ago was an arid wilderness covered with sage brush. All kinds of vegetables, I was told, grow well in the light soil, and fruit-trees are being planted.

The settlers in this part of America have, I think, shown splendid energy and enterprise in converting this uninviting-looking country into well-cultivated 
land. Of course they could have done nothing without the water, but in many cases the water has been led out from the river for miles to their homesteads, at the cost of an enormous amount of labour. Many of these hard-working people, I was told, were Mormons from Utah, who are said to understand cultivating land by means of irrigation better than any other people in the United States. If Mr. Rhodes could only manage to transplant a few hundred of these hard-working Mormon families to the high plateaus of Matabeleland and Mashonaland, what a transformation they would work in those countries in a few short years! provided always they did not succumb to the influences of their new environment, and gradually come to consider manual labour derogatory to a white man in a country where there exist numerous aboriginal dark-skinned races, who can be hired to work and sweat in the hot sun whilst the European contents himself with the part of overseer. There are, of course, some countries where white men cannot work all day in the sun; but on the plateaus of the interior of South Africa they most certainly can, and would, were it not for the presence of the less civilised black races.

On the afternoon of September 6 we got into a country where a few prong-horned antelopes still roamed; but although we left the road and made a long détour in search of them, we did not come across any of the animals themselves, though we saw a few 
fairly fresh tracks. On this day, too, we saw and killed our first rattlesnake. We also sighted a prairie wolf (Canis lupus occidentalis) in the distance, and came on a badger (Taxidea americana), which retreated in so leisurely a manner that after dismounting from my horse I ran up to it without difficulty. I could have killed it with a club, had I had one, but did not care to shoot it, as I knew that an expanding bullet would damage its skin very much, so I allowed it to retire into a large burrow. It went to ground backwards, always facing its enemy, in the same manner invariably practised by the South African wart hog, which, no matter how hard pressed it may be, never bolts head first down a hole, but always turns round and goes down backwards.

On the following morning we killed a rattlesnake close to our waggon, after having first photographed it. It seemed a very lethargic kind of reptile, possibly because the early morning air was somewhat chilly, and would not move or give the warning rattle although I had got my camera on the ground at a distance of only four feet away from it - until Graham stirred it up with a stick. Then it raised its head a foot or so from the ground and made a somewhat feeble noise with its rattle. Whilst photographing the rattlesnake, I saw three sage grouse walking through the brush a short distance away. One of them was a splendid old cock, apparently about the 
size of a capercailzie hen, but with longish pointed tail-feathers.

Thinking that it would be a good thing to shoot a couple of these birds for the pot, - for we had seen nothing in the shape of game since leaving M's. ranch, with the exception of the unapproachable geese and a couple of hares, - I was walking to the waggon to get a shot-gun, when three prong-horned antelopes appeared on the top of a piece of rising ground about five hundred yards distant. They had probably been intending to have a drink in the very nasty alkali-impregnated waterhole by the side of which we were camped. They now stood gazing at us from their safe position on the top of the high ground for several minutes, and we were able to examine them carefully through our glasses. They all three carried horns, and were therefore males, the female prong-horned antelope being hornless. After having satisfied their curiosity, which was not sufficient to bring them any nearer to us, they turned round and disappeared behind the ridge.

M., having already shot prong-horned antelopes, asked me to go after them, which I at once proceeded to do. I had observed that as they disappeared they were heading to the left, so I made a longish détour and presently sighted them amongst some very short sage brush about four hundred yards from me. From here I crawled within two hundred yards of them. This was a very disagreeable process, 
as all over these alkali plains there grows in great profusion a kind of dwarf cactus, whose thick fleshy arms, which only appear just above the surface of the ground, are thickly covered with innumerable little sharp spines, which on being touched at once become detached from the parent plant and adhere to one's flesh in little clusters. The sides of these little spines are minutely serrated, which causes them to work their way deeper and deeper into whatever they have adhered to. They are said to often cause festering sores, but I suppose that is when one's blood is out of order.

After my stalk was over, I found my knees and thighs, elbows and hands, full of these cactus spines; but at the time I was approaching the antelopes I was so intent on the business in hand that I did not pay any attention to them. When I was about two hundred yards away from them, I think one of the antelopes saw me, but could not quite make me out, as I was lying flat on the ground. He trotted away for a few yards and then stood nearly broadside with his head turned, looking backwards. Not seeing any chance of getting nearer, and as I could see him better than either of the other two, I fired at him as I lay, and heard the bullet tell. He dashed away, however, together with his companions; but I did not think he would go far, as I was using a Mannlicher rifle and expanding bullets. Running quickly to the spot where the antelope had stood when I fired 
at him, I at once saw blood on his tracks, and on creeping to the top of the rising ground behind which he had disappeared, saw him standing about three hundred yards away. One of the unwounded antelopes was close to him, the other being some dis-

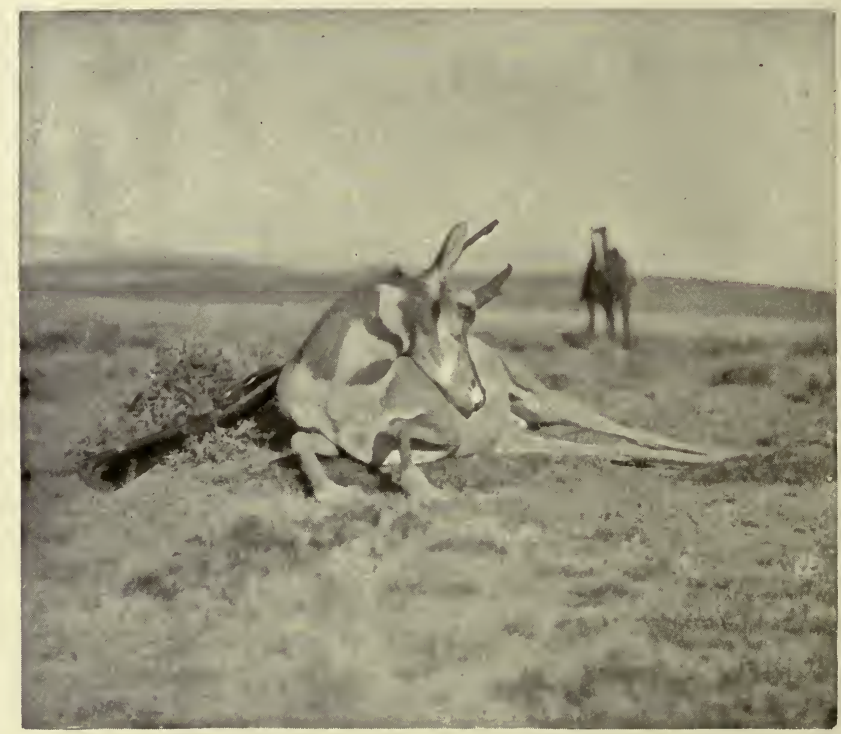

Prong-horn Buck, shot in the Bighorn Basin, September, i 897

tance on ahead. Both of these were holding their heads high, and were gazing steadily towards where I lay, whilst their stricken comrade was walking slowly forwards with drooping head. I could see he was badly wounded, and so determined to finish him before turning my attention to his friends. These, however, bounded away through the sage 
scrub immediately they heard my shot, which dropped the wounded antelope in his tracks. On walking up to him, I found that my bullet must just have skimmed along his back, and catching him in the back of the head had come out on his forehead.

Having heard my shots, Graham now came galloping up, and finding that my stalk had been successful at once rode back to the waggon to fetch my camera and bring a pack horse to carry in the meat, whilst I sat down - on a carefully selected spot and commenced to extract as many cactus spines from my knees and elbows as possible. I found, however, that numbers of these little prickles had broken off and were very difficult to get hold of, and the greater part of these I had to put up with; but though I could feel them for a long time afterwards, if I pressed on the spots where they had disappeared, they never caused any inflammation. Whilst taking the antelope to the waggon, I very nearly stepped on a rattlesnake, which lay perfectly still, coiled up under a little sage tuft, and never moved until struck with a piece of wood. These rattlesnakes appeared to me to be as lethargic as are South African puff adders on a cold morning, and I was glad that this one had not been lying exactly in my path as I was crawling up to the antelopes, or I might very easily have put my hand on it before noticing it. The dead pronghorned buck - a fair-sized male, Graham said, and in good condition - weighed I $09 \frac{1}{2}$ lbs. as he lay, and 
83 lbs. clean - within I lb. of 6 stones. The scientific name which has been given to the prong-horned antelope - Antilocapra americana, American goat antelope - appears to me, now that I have seen these animals in their native haunts, to be a singularly

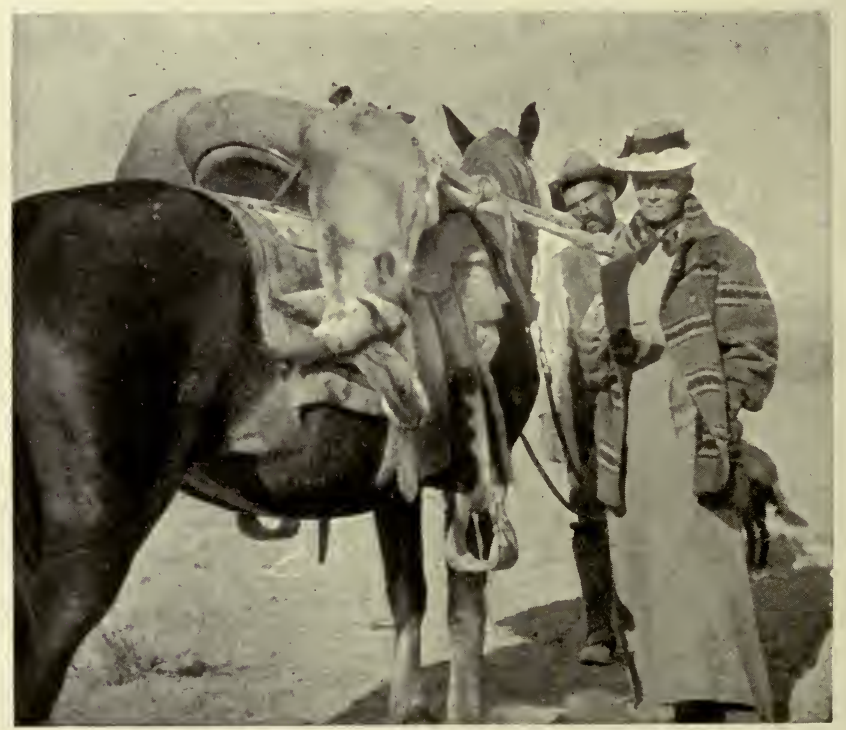

Prong-horn Buck just brought to Camp, September, I897

inappropriate one; for in habits and appearance, the form of its finely cut legs and longish sharppointed hoofs, the nature of the country it frequents, and indeed in every other particular, with one curious exception, the animal is a true antelope, and is as far removed from any species of wild goat as it is from a sheep. The one point in which it differs from 
the antelopes of the Old World - the annual shedding of the horn-sheaths - is certainly a most remarkable distinction, but does not bring it any nearer to the goats.

As the process by which the horn-sheaths of the prong-horned antelope are annually shed and renewed is, I think, not generally understood and the fact itself often doubted, I make no apology for here quoting from the very interesting account written on this subject by the well-known American naturalist, Judge Caton. After speaking of certain observations which he had made on the horn growth of a young prong-horn buck running in his park, the author of "The Deer and Antelope of North America" goes on to say: "Let us observe the horn of the adult male antelope which is shed in October. If we make our observation so soon as the horn is cast off, we can readily understand the process by which it is removed. By looking into the cavity of the cast-off horn, we shall see that it extends but about half-ivay its length, or a little way above the prong; and we shall also see that it contains a large number of coarse lightish-coloured hairs, all of which are firmly attached to the horn, and many of them, towards the lower part, passing quite through it. We see the core of the horn is covered with a thick vascular skin, which is pretty well covered with the same kind of hairs as those seen in the cavity of the horn. We now appreciate that these hairs grew from the skin 
and more or less penetrated the shell or horn, and when this was removed, some were torn from the skin and others from the horn. We observe further that the new horn had commenced its growth a considerable time before the old one was cast, for the new horn was extended several inches above the top of the core, nearly in a vertical direction, though with a slightly posterior inclination. The top of this for nearly half an inch is already hardened into perfect horn. Below this it is softer, and a little way down it has lost the horny texture, but is a pretty firm and somewhat flexible mass down to the core and around it, at the upper part of which, however, it has rather the appearance of thick, massive skin of a high temperature, showing great activity in the blood-vessels permeating it. As we pass lower down, the skin is thinner and shows less excitement or activity. Upon this skin, enveloping the core, we find the hairs already described.

"This was the condition of the new development when the old horn was cast off. It shows that the new horn had already made considerable upward growth from the top of the core, and tearing out the hairs, the roots of which were in the skin, and many of which extended into or through the old horn. Until these were mostly torn asunder or were withdrawn from the canals by which they had penetrated the shell, they served to prevent it from being easily lost; but finally, when these were all or nearly all severed, it fell 
off, as a favourable position occurred or some slight violence assisted the removal. I have never observed the animal to assist this process by rubbing its horns against convenient objects, but my opportunities have not been such as to authorise the statement that they do not sometimes do so.

"When the old horn was cast off, the new one, as we have already seen, had made a considerable growth above the core, which was already tipped with perfected horn, and a section below it was more or less hardened, or partially converted into horn. This intervening section gradually moved down the horn, constantly invading the soft skin below, and followed above with perfected horn. All this time the horn was growing in length above the core, and assuming that posterior curvature near its upper part which so much resembles the curvature of the horn of the chamois. After the horn is perfected down to the top of the core, it ceases to increase in length, while the apparently converting process steadily progresses downward along or around the core. The core being laterally compressed, the horn assumes that form, not, however, conforming precisely to the shape of the core, but extending considerably in front of it, where it is thinner than the posterior part. At the upper extremity of the wide, flattened part, the snag or prong is thrown out, which consists of little more than an abrupt termination of the wide part, with an elevated anterior point. 


\section{I70 SPORTAND TRAVEL}

"By the latter part of winter, on the adult, the horn has attained about this stage of growth. From this it presses on, hardening in its downward growth till the latter part of summer or the commencement of the rut, by which time the growth is perfected down to the base, and is a complete weapon for warfare, and it so continues during the rut, and until the growth of the new horn is commenced and loosens the old one from its core, and raises it from its seat, as has been described."

The range of the prong-horned antelope has been very much curtailed of late years by the steady occupation of the prairies and deserts of western America by the insatiable white man. These antelopes used once to collect at certain seasons of the year, it is said, in immense droves; and even yet there are localities, I was told, where upwards of one hundred may sometimes be seen together. I have seen in all perhaps a dozen little lots of these animals, varying in number from two - a female with her fawn - to a herd of from fifteen to twenty individuals, amongst which were two fine males. They always reminded me of spring bucks in South Africa, both by their general colour and appearance and the arid nature of their surroundings, and I should think they must resemble Sœmerring's gazelles at a little distance even more nearly.

The general colour of the prong-horned antelope is fawn, with a conspicuous white rump and a white 
belly. I once saw some does and fawns erect or in some way spread out the large patch of white hair on their rumps. I had left my horse, and was trying to stalk a fine buck, when these animals trotted past me, all unconscious of my proximity, though evidently uneasy at the sight of the horse with a saddle on him. As they trotted slowly past me, they all seemed to have their backs humped up, whilst the white hair on their hind-quarters seemed to be bristled up in such a way as to make this part of their bodies look much larger than it really was. Instead of following the ewes, as I had hoped and expected he would have done, the old buck went off by himself and never gave me a chance of a shot at him.

After having cleaned and cut up my first antelope as already described, we again proceeded on our journey, and on the afternoon of September 7 passed the embryo township of Marquette. Some six miles farther on we spied a few antelopes feeding near the foot of a low range of hills, distant about a mile away from the road. After carefully studying the ground, I determined to try and stalk them, but it was first necessary to make a long détour on horseback in order to approach them from behind the hills. As we thought these antelopes must be accustomed to seeing people riding along the road, Graham and W. M. rode steadily forwards, whilst I rode in the opposite direction until well out of sight, and then cantered round to the back of the hills. On my way I put up six 
coyotes (Canis latrans), two of which stood and looked at me within a hundred yards, but I was afraid to fire at them for fear of disturbing the antelopes. Leaving my horse in a little hollow, I crept to the ridge of a low hill, and again espied the white rumps and buff-coloured hides of the wary game I was pursuing. After carefully studying the intervening ground, I commenced my stalk and at length got to within two hundred and fifty yards of the antelopes. They were seven in number, - a big buck and six does and fawns. They were now all lying down, but as I watched they got up one after another, and fed slowly over a little rise in the ground, and I then saw that I could get nearer to them by crawling a short distance backwards, and getting into a little gully. I should probably have succeeded in creeping to within easy shot of them, had not a coyote run out in front of me, right on to the antelopes, which must have taken fright and gone off at once, as when I reached the top of the rise from which I had hoped to get a shot, they had disappeared, nor could I see them anywhere.

I then went back and got my horse, and after riding about for some time at last sighted the antelopes on the top of a high terrace. On seeing me they at once started to come down towards the lower ground, and by galloping hard I was able to get within two hundred yards of them as they raced by. The big buck came last, and I missed him with my first shot, but hit him with the next when he was about three hundred yards 


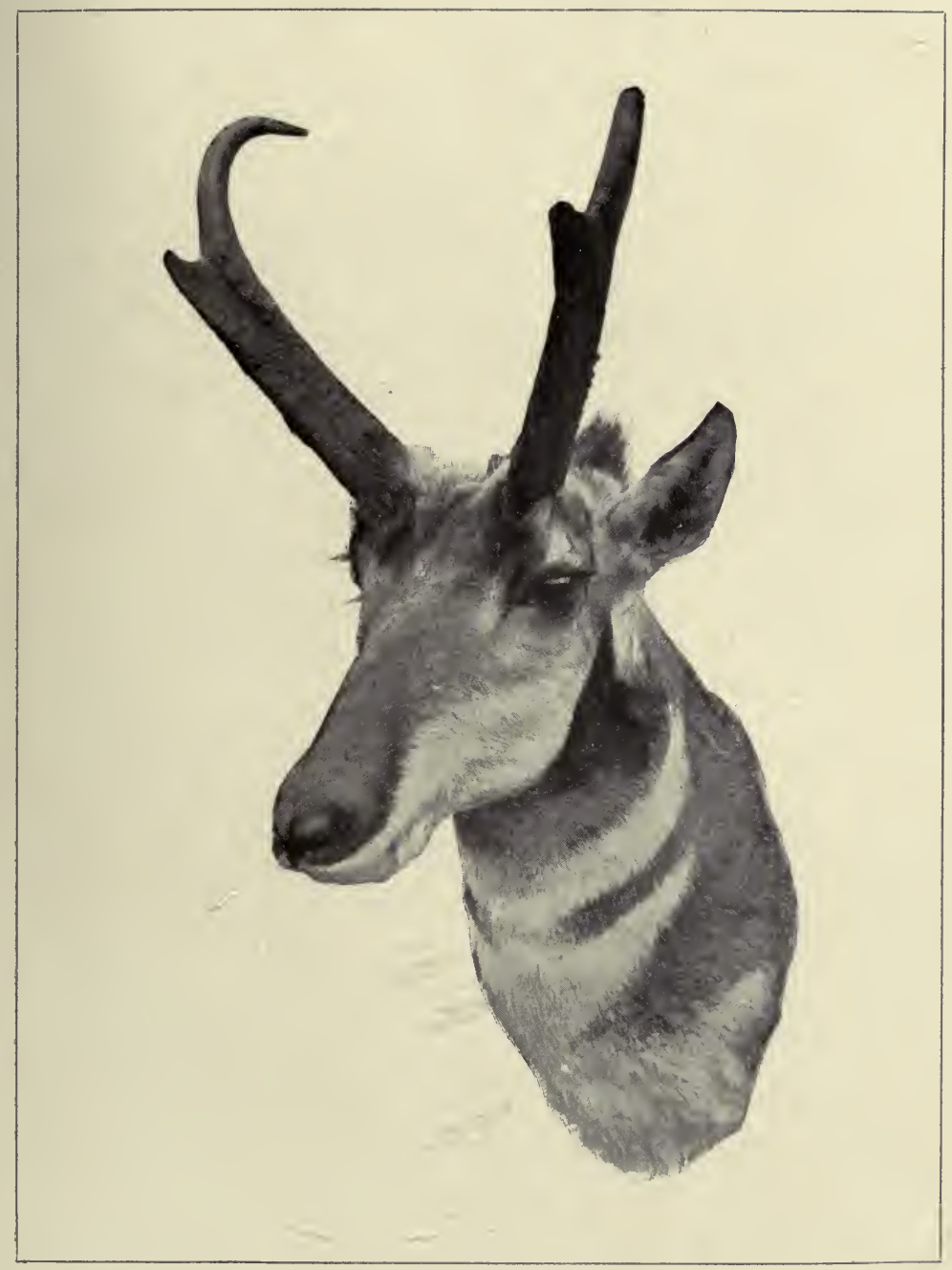

HEAD OF PRONG-HORNED ANTELOPE

Shot near Dry Creek, September, I897

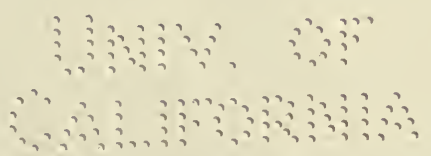




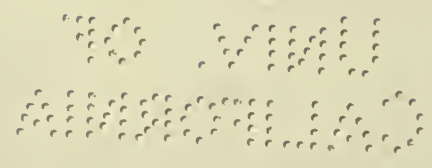


away and still going like the wind, - an extraordinarily lucky shot, no doubt, but none the less useful on that account. The bullet broke the unfortunate animal's thigh high up, and then passing through his entrails came out behind his ribs on the other side. On being struck, he turned right round, and came rushing towards me, and having crossed a little gully followed its course for a couple of hundred yards before lying down. I then killed him with a bullet through the lungs. He proved to be a remarkably fine animal, in splendid condition, with a finely coloured skin, and carried a very pretty pair of horns, fourteen and a half inches in length. He must have weighed, too, a good deal more than the first one I shot. The sun had now been down some time, and the light was fast going, so cutting off his head and as much meat as I could pack on my horse, I started for camp, which I did not reach till long after dark.

We were now just within the mouth of the valley through which runs the South Fork of the Stinking Water River, on emerging from the Rocky Mountains; and we travelled along the course of this stream for two days before reaching the last settler's ranch, a small $\log$ cabin inhabited by a hospitable Welsh family of the name of Davies, - at least Davies was a Welshman, though his wife was an English woman.

The North and South Forks of the Stinking Water River meet just above Cedar Mountain and then run in one rushing stream through a deep canyon which 
divides this last spur of the Rattlesnake Mountains from the main range. A little below the gorge there are some very remarkable hot sulphur springs, some of which are situated just at the edge of the river, whilst others come bubbling up to the top of the water

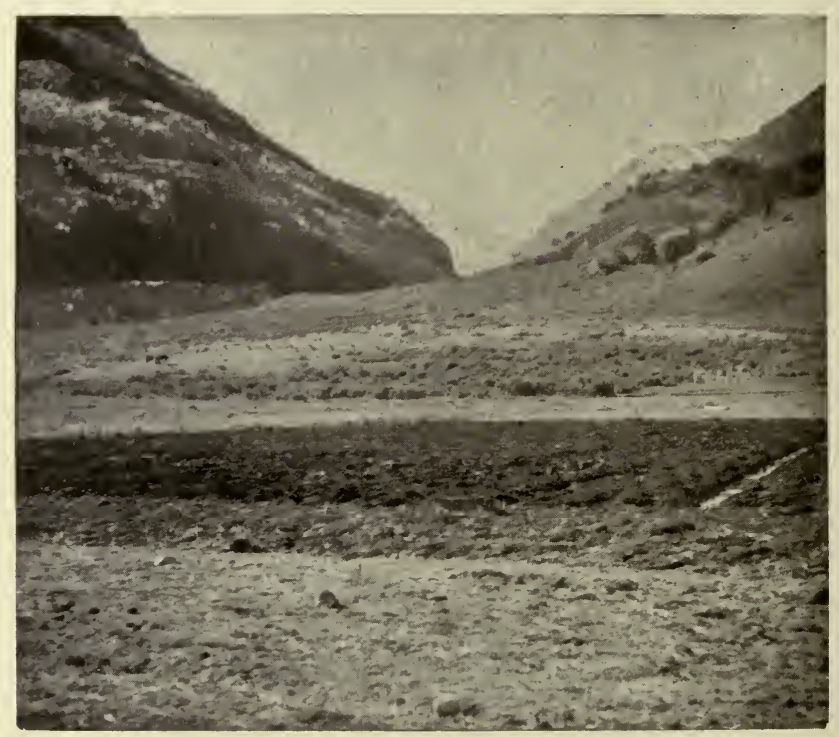

The Valley of the South Fork of the Stinking Water River

from the bed of the stream itself. The smell of these sulphur springs is very strong, and is perceptible at a distance of several miles down wind. To this fact does this beautifully clear mountain stream owe its unsavoury name, Stinking Water being the literal translation of its old Indian designation. The sulphur springs, of which I have spoken, are now known to 
possess medicinal properties of a very useful nature. Their temperature, which is exactly blood heat, ninety-eight degrees, - never varies, summer or winter. If all I heard concerning the curative properties of these springs is true, - they are said to be specially efficacious in cases of chronic rheumatism and syphilis, - invalids will soon be resorting to them from all parts of the United States, if not from Europe. Already the world-renowned Colonel William Cody has started a small township in their vicinity named after its founder "Cody City," whilst a small house of accommodation and a plank-built bathroom, heated with a stove in winter, have been put up at the Springs themselves.

Both the North and South Forks of the Stinking Water River, clear cold mountain streams of purest water, are full of delicious trout. They contain greyling, too, which I thought very good eating, though locally they are not much esteemed. The trout are not able to get more than two-thirds of the way up the South Fork, owing to the fact that they cannot pass a certain small waterfall; but whenever we were camped near the water below this fall we could always secure a good dish of trout for breakfast or dinner. They were uneducated fish, - which is what I like, - and when on the feed would rise readily at almost any kind of fly. They were of a fair size, too, on the average, and we caught many weighing from one pound and a half to two pounds. Once I caught 
a dozen or so with an artificial minnow, that must have averaged nearly two pounds each.

Davies' cabin, picturesquely situated just at the junction of Cabin Creek with the South Fork of Stinking Water, we at last reached by midday of September 9 .

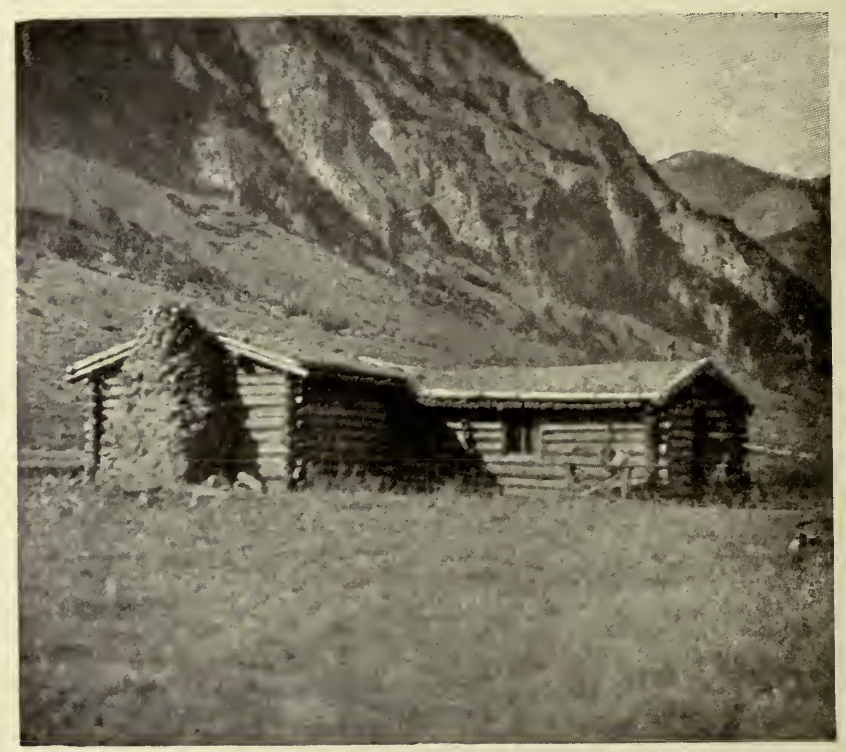

Davies' Ranch, South Fork of Stinking Water River, September, I897

This was the goal of our waggon-journey, as the narrow trail leading up the gorge into the rugged and uninhabited mountains beyond was impassable for anything but pack ponies. We lost no time in off-loading the waggon (which we left in charge of $\mathrm{Mr}$. Davies) and arranging the loads for the horses, and on the afternoon 
of September ro bade adieu to the kind-hearted Welshman and his wife, and commenced the last section of our journey into the main range of the Rocky Mountains, where we hoped to meet with at least a few wapiti and mule deer. That afternoon we did ten or twelve miles along a very rough track, sometimes in the bed of the stream, sometimes along steep slopes and stone slides high above it, but always in a very wild and beautiful country with rugged pine-clad mountains above and on either side of us, and rushing water below us. In the evening we caught a few trout for supper and camped in a lovely little glade about eight thousand feet above sea level.

Late in the afternoon of the following day we reached a spot where Graham had intended us to camp for a week or ten days, as he thought that it would prove a good centre from which to hunt wapiti. Another party of English sportsmen, - and women, - whose fresh horse-tracks along the trail had already caused us some anxiety, had, however, selected the same locality for a camp, so of course we had to move on at once to get beyond the sphere of their influence. Although we remained unavoidably, for the next month or so, more or less within touch of one another, I scarcely think we could have interfered with one another's sport in any way, as we were in the midst of a vast tract of country, throughout which wapiti were everywhere sparingly scattered, whilst they were nowhere particularly numerous. 
Whilst the tents were being pitched, I walked a short distance away and was just strolling through a grove of pine-trees when I saw an animal coming towards me at a slow trot. At first I thought it was a young deer coming along with its head held down;

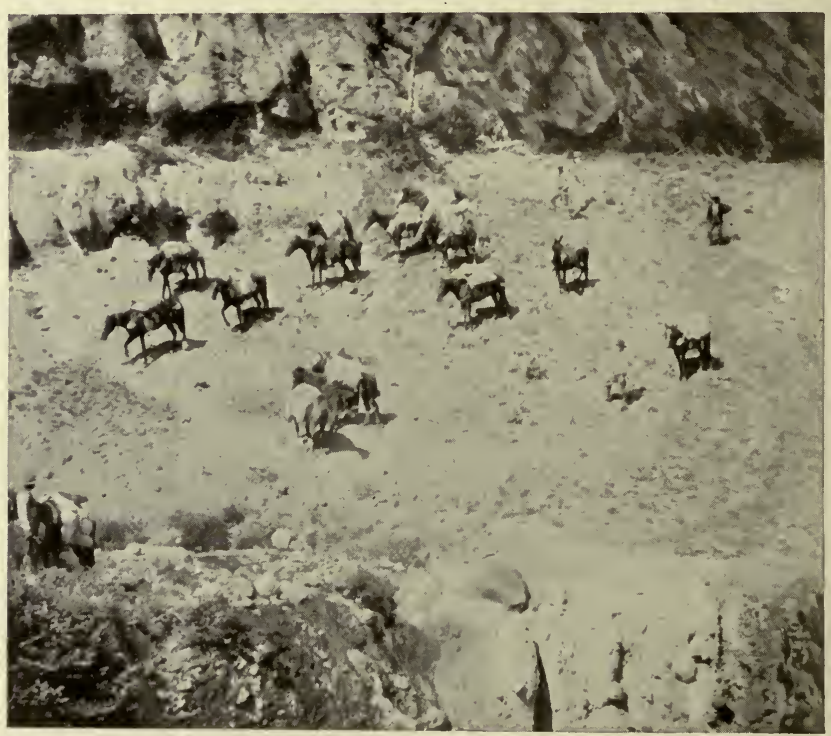

Travelling with Pack Ponies up the South Fork of the Stinking Water River; Crossing a Bit of Rock

then I thought it must be a puma; and finally I saw that it was a lynx. I stood perfectly still, and it came steadily on to within fifteen yards, before seeming to notice me. Then it halted and stood looking intently at me, evidently not quite able to make me out, and all the time twitching its little bobtail. I had not my 
rifle with me, so could do nothing but watch it. Presently it turned and trotted off sideways, and soon disappeared amongst some low scrub near the river. As soon as it was out of sight I ran back to camp, and picking up my rifle returned in search of the lynx. I had been looking for it for several minutes, and as there were several patches of thick scrub about, was commencing to give up all hope of ever seeing it again, when it suddenly came into view once more, trotting slowly along as before. I at once fired at and hit it, the expanding Mannlicher bullet tearing a big hole through the skin where it came out. It proved to be a very fair specimen - a male - of the Canadian lynx (Lynx canadensis), which I was very pleased to have secured for my collection, as these animals, though frequently trapped, are not often shot.

We had now reached a country where with luck wapiti might have been encountered at any moment, since it was impossible to walk many miles in any direction without crossing tracks of these magnificent animals, either fresh or not many days old, whilst here and there small spruce saplings half peeled of their bark, and with their lower branches beaten to the ground, showed where some lordly stag had lately rubbed the velvet from his horns. Yet I hunted hard for twenty days, and during that time probably walked on an average quite twenty miles a day in very rough country, before I carried my first wapiti head back to camp. 
During this time we moved about a good deal, at one time being camped at a height of 10,500 feet above sea level on the summit of the pass which divides the head waters of the South Fork of Stinking Water from those of a tributary of the Wind River,

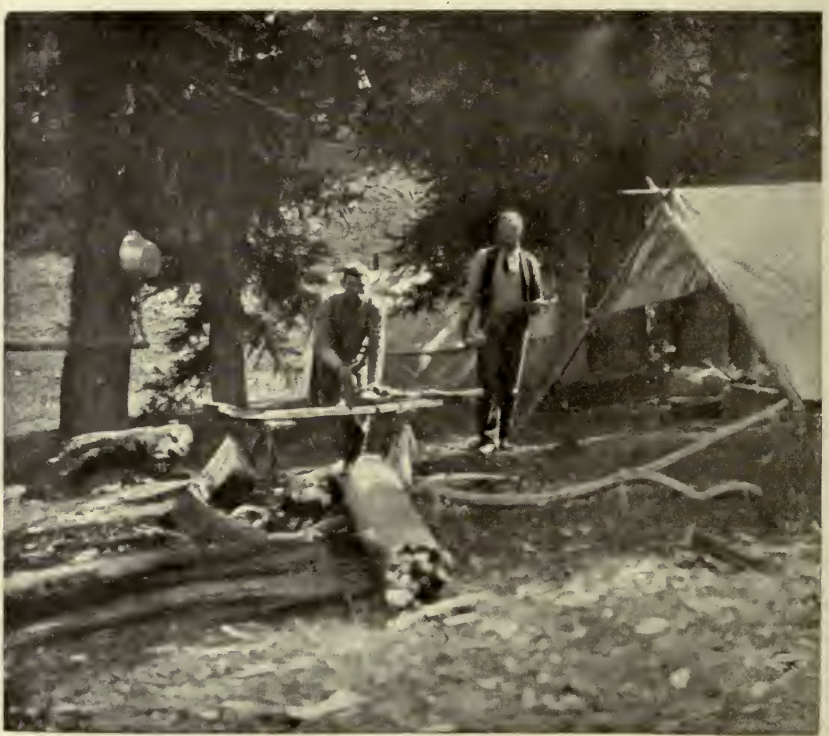

Camp on the Divide at the Source of the South Fork of the Stinking Water River; io,500 Feet above Sea Level

and then crossing the divide and hunting to the southwest as far as what I think was the main branch of the Wind River itself, working back again towards the end of September. Never once, however, though I wandered over so much country during the height of the rutting season, did I hear a wapiti bull challeng- 
ing a rival. The noise they make, I am told, can be heard at a great distance, especially at night or early in the morning, but the quality of the sound is altogether different from the roaring or bellowing of the European red deer during the love season, and is always spoken of as whistling or bugling. When very much the victim of the tender passion, the wapiti often seems to lose all sense of fear, and becomes, in the expressive language of the Western frontiersmen, "clean crazy." In this condition an amorous bull will sometimes not only not run away from a suspicious object or sound, but come towards it, challenging as he advances.

My companion, W. M., when out with Graham one day towards the end of September, heard a bull whistling late in the afternoon, and had approached within a short distance of it - though he could not see it, as it was hidden behind a piece of rising ground - when he made a slight noise by displacing a stone. The wapiti evidently heard the sound and at once advanced towards it, the tops of his horns soon appearing above the crest of the rise. My friend then sat down, holding his rifle at his shoulder in readiness for a shot. Gradually the great stag's horns came more and more fully into view, then its finely modelled head appeared, and lastly the great swollen neck, looking larger than it actually was from the length of its bristling coat of dark-brown hair. As he came forwards the angry animal constantly 
gave vent to various sounds which ranged from a clear musical note, like that of a bugle call, to something nearly resembling the braying of a donkey. This bull was in possession of four cows, which were, however, at this time out of sight behind him, and he not only seemed to be prepared to keep them against all comers, should his rights be disputed, but even appeared to be in such a jingoistic frame of mind that he was anxious to have them disputed. In fact, he seemed to be not only willing to fight, should occasion arise, but anxious to find an occasion to display his prowess.

My friend was of course in full view as soon as the wapiti's eyes were above the rise, as were also Graham and a very well-broken black retriever dog, which sat during this trying time solemnly still without moving or barking. W. M., fearing lest the wapiti might suddenly recover from its frenzy, or that the dog might rush in and frighten it away, deemed it wise not to wait till it showed its whole body above the rise, and so shot it through the neck. It at once dropped in its tracks, but rolled some distance down the hill, breaking one of the tines of its horns short off against a stone. On stepping off the distance from where he had been sitting to the spot where the wapiti first fell, my friend found that only seventeen yards had separated them when he fired. The following morning, when Graham and W. M. went to cut up the dead wapiti and bring in the head, my 
wife went with them to take some photographs, and whilst assisting in the search for the tine that had been broken off, came on the body of a mouse, which had evidently been killed and squashed flat by the sudden fall of the great stag!

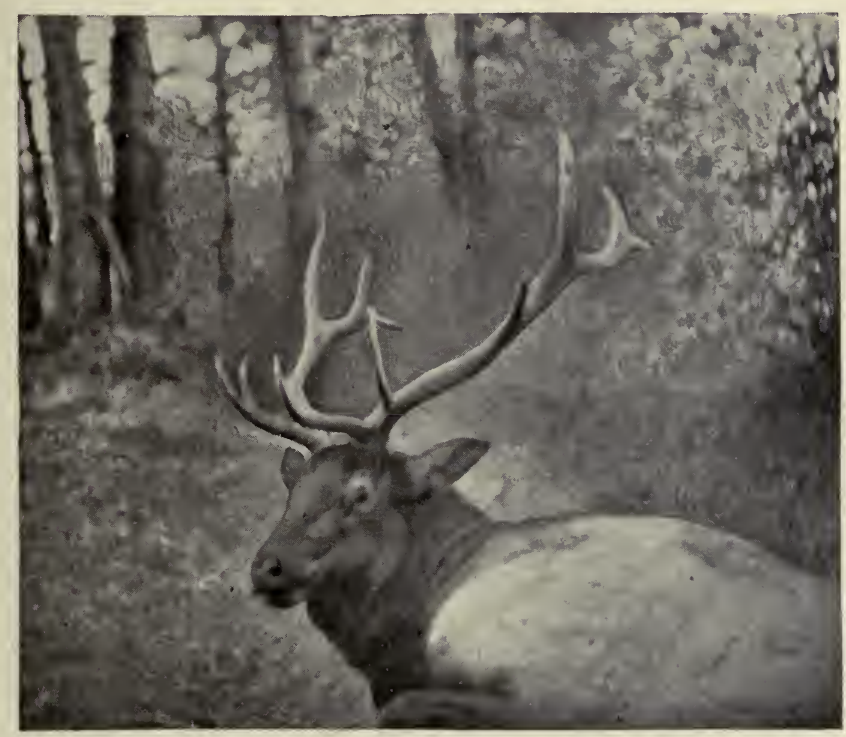

Dead Wapiti shot by W. M., September, I897

Judging from the accounts I have read of hunting in the Rocky Mountains some twenty years ago, wapiti were then very easily shot. At that time they were of course very plentiful, and wherever they had not been much persecuted, probably not very wary. Now things are very different, at any rate, in the district where I have hunted them amongst the mountains to the east 
of the Yellowstone Park; for there, at any rate, they are not only very wary, but far from plentiful. The ground they frequent in the autumn months is almost entirely covered with dense pine forests; and until they are driven down by heavy snow-storms, they keep pretty high up, not far below timber line, which in Wyoming must be about eleven thousand feet above sea level. The senses of scent, sight, and hearing have all been highly developed in the wapiti by constant persecution; and when not thrown off their balance by passion, these animals are often extremely difficult to get a shot at, as the forests in which they live are as a rule so dense that even so large an animal as a wapiti bull may be quite invisible at a distance of fifty yards. In my small experience I have found wapiti bulls much more wary, timid, and cunning than the cows. At the slightest sound the former will usually run off, without waiting an instant to verify their suspicions, whilst the latter, as a rule, stand listening until they actually see something.

I can imagine no more perfect country in which to hunt than the Rocky Mountains must once have been, when game was still plentiful. A few fair heads can still be got by hard work and perseverance; but for every head obtained, a good deal of hunting must now be done, and the great herds of game which according to tradition were once so numerous, and the constant sight of which must have added such an indescribable charm to their wild and beautiful sur- 
roundings, have now disappeared for ever. Still the glorious air and the grand wild scenery of the Rocky Mountains remain, and that favoured region is still the home of at least a few of the grandest stags to be found on our planet; whilst mule deer and big-

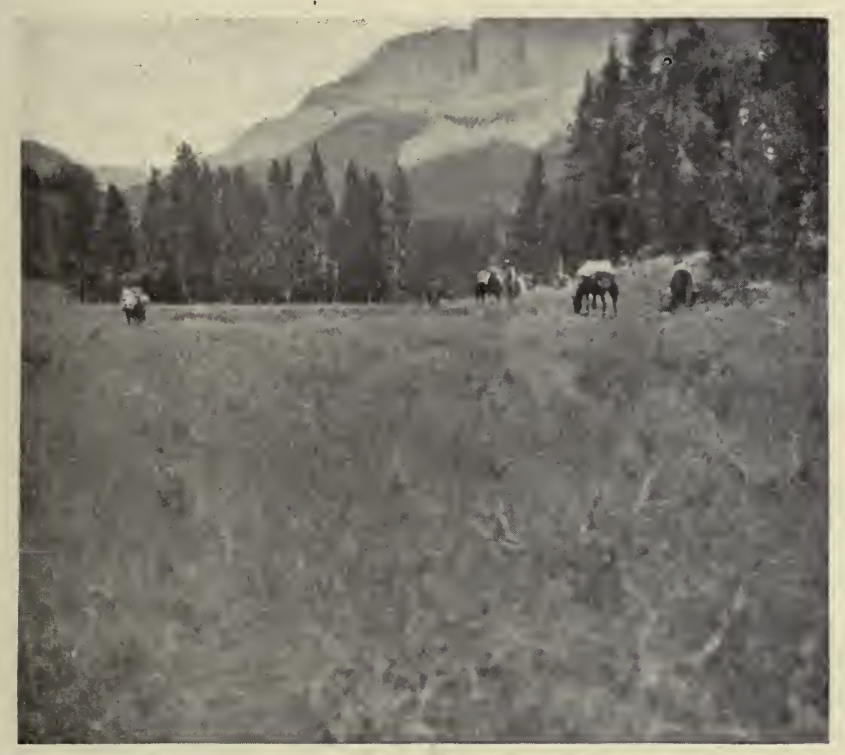

A "Park" in the Rocky Mountains; Pack Ponies Grazing DURing a Halt, September, I897

horn sheep, both very fine animals of their kind, are by no means yet extinct.

The grandeur and wildness of the scenery itself in these American mountains was to me a constant delight; for whilst tracking wapiti high up near the verge of timber line, I was always wandering through scenes 
of surpassing loveliness, and once when on suddenly emerging from the shady depths of a dark pine forest, I found myself on the sedgy shore of a little lake, set like a gem in the bosom of the fragrant woods, the picture presented to me was so exquisitely beautiful that it seemed to be the realisation of a scene that had been flashed across my mental vision in some still halfremembered dream. Only in my dream there had been wild creatures feeding by the water's edge, as indeed there might have been in the actual picture I have endeavoured to describe; for we found tracks of both wapiti and mule deer on the grassy slope which lay between the lake and the surrounding forests, but these wary animals do not nowadays often show themselves in any open place during the daytime.

During the month of September, as I have said, I hunted with but little luck. I had, however, one excellent chance at a young wapiti bull. Having seen pretty fresh tracks when out by myself late one afternoon, I proceeded to look for the animals that were responsible for them early the next morning. It was still early when, having climbed to the summit of a detached range of hills, in company with Jinks, we caught sight of two wapiti hinds amongst the pine-trees at the foot of the slope. Taking stock of the hinds, we at once commenced to descend towards them, hoping to find that they were stragglers from a herd, with which we hoped there might be a big bull. We got down the hillside as quickly as possible and had just 
reached the bottom, well to the right of the hinds, when we heard some stones move still farther to our right; and the next moment I saw a large animal trotting amongst the trees at a distance of not more than seventy or eighty yards, and as the pine-trees were here

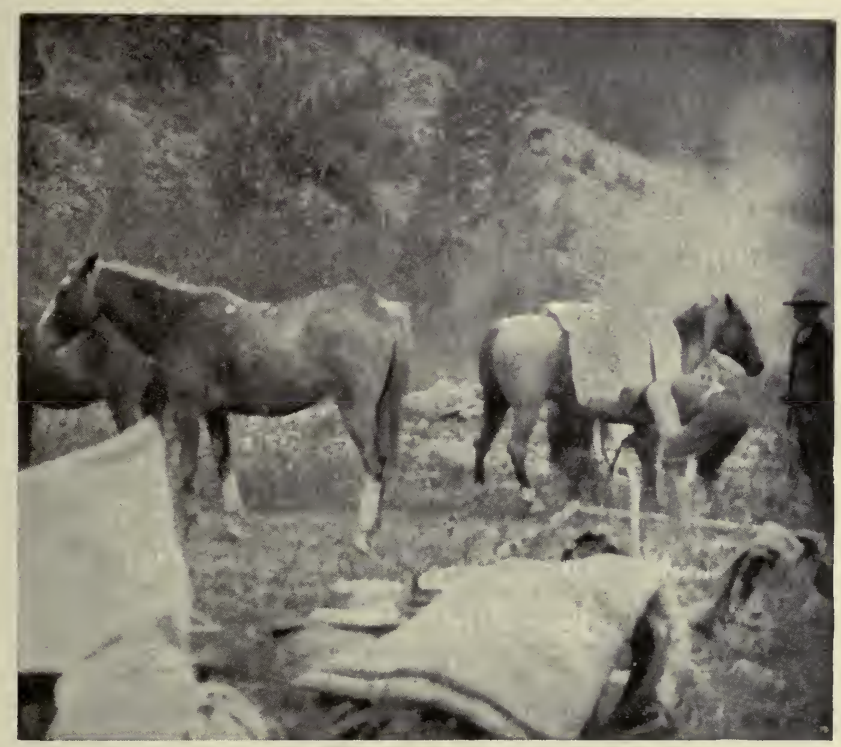

Preparing to Strike Camp in the Rocky Mountains, SEPTEMBER, I897

growing not very thickly together, soon made it out to be a bull wapiti. It had evidently neither seen nor scented us, but must have heard us. When I first saw it, it was coming obliquely past us, and as I thought it was going to stop, I waited for it to do so. It very soon came to a halt, and stood broadside to me, with 
its head just beyond the stem of a large tree, which covered its whole neck and part of its shoulder. Another tree covered its hind-quarters, but all the rest of its body was exposed, and there was nothing therefore to hinder a bullet from reaching its lungs.

I was now sitting down with my elbows resting on my knees, and this large animal was not more than one hundred yards away from me. As I pulled the trigger, I believed myself to be perfectly steady, and felt absolutely sure that I was not only about to hit, but to kill my first wapiti with a shot through the lungs. At the report of the rifle, however, he showed no sign of being hit, but just moved a couple of steps, and having half turned at the same time, stood in such a way that I could see nothing of him but his head and a piece of his hind-quarters. Thinking he would again walk forwards and give me another chance of a shot at a vital spot, I reserved my fire. After standing still for a few seconds, however, he dashed off without giving another chance, as he was always covered more or less completely by tree stems. His actions after my shot had certainly given no indication that he was wounded; but it is difficult to make sure on such a point; and I could not believe I had missed him. Indeed, I fully expected to find him lying dead at no great distance, shot through the lungs. However, after having followed on his tracks for several miles without finding a single drop 
of blood, I could only conclude that I had made a clean miss. I have made many bad shots in my time, but never, I think, quite so bad a one as this. In fact, it was an unaccountably bad shot, as I was sitting down and quite cool and steady as far as I know. A Mannlicher bullet sometimes goes wrong, I am told, owing to the nickel coating parting from the lead core as it leaves the muzzle of the rifle. If something of this sort did not happen, I certainly made a record bad shot on this occasion. I must say I felt very sore about it, though the wapiti I had failed to kill was, I knew, not a very fine one. Jinks thought he was about a three-year-old bull, and said his head would not have been worth carrying to camp, - an assertion which, though comforting in some ways, did not make me feel any better satisfied with my bad shooting.

Besides this remarkably easy shot at a young wapiti bull, I got another difficult running shot at what I think was a very fine one. Graham and I had been tracking a small herd of six or seven cows accompanied by a bull - as we knew from the hoofprints - for many hours, when on reaching the top of a rise which we had ascended amongst thick-growing pine-trees, we came suddenly to the edge of an open piece of ground, which sloped steeply down to where it again met the forest some one hundred and fifty yards below. This piece of ground was covered with grass, but quite devoid of trees or bushes. Imme- 
diately I reached the edge of the timber; but before I had stepped into the open ground I saw three or four wapiti hinds standing just on the edge of the forest at the foot of the open grass slope, and almost at the same moment caught sight of a great bull, with what seemed a beautiful pair of wide-spread antlers, going off at full gallop through the pine-trees.

The chance was not a good one, but I knew I should not get another, so getting the sight on to some part of his back, - I was high above him, - I fired and thought I had hit him, as at the shot he swung right round, and running under the thick low-hanging branches of a large pine suddenly stopped. He was, however, quite invisible. Then the hinds came running across the lower edge of the open ground, and the next moment I saw the branches of the pine where the stag had been standing move, and caught occasional glimpses of parts of him as he once more dashed off amongst the tree stems. This time, however, I found it impossible to get a shot at him. This wapiti stag did not rejoin the hinds, but went off by himself, and we never saw him again. We found no blood on his spoor, and whether my bullet hit him, grazed him, or missed him altogether, I do not know; but as I did not get him, I hope it was the latter. It was a poor chance at best, and the luck was never with me at this time, as it was when I killed the big prong-horn buck, and again later on after I had had a month's chastening.

Besides the two wapiti bulls which I actually saw 
and fired at during September, as I have described above, I one day caught half a glimpse of a third. Graham and I got his fresh spoor high up near timber line one morning. Heavy rain having fallen the previous night, all the twigs and pine needles, lying on the ground beneath the trees, had been well soaked and so made no noise when trodden upon, as they bent to the foot, instead of rustling or cracking as they do when dry. We were thus enabled to track this wapiti bull almost noiselessly, and had the timber been a little more open, I should doubtless have got a shot at him. Unfortunately he was lying in a thick patch of spruce; and although we saw a bough move as he jumped up, and I just caught a glimpse of his whitish rump as he jumped away, I had neither the time nor the opportunity for a shot. I ran forwards as hard as I could, but saw nothing more of him in the thick timber. We then took up the tracks and followed them a long way, but never caught sight of the wary brute again; nor indeed after having once disturbed a wapiti bull, have I ever set eyes on one of these animals again, though I have followed some for hours.

It was not till September the 29th that I saw a mule deer buck with a head worth keeping, though I had previously shot quite a young one for the sake of the meat. On the occasion in question I was walking along a steep side-hill thickly covered with spruce and pine trees, when my eyes suddenly became aware of 
an animal just above me. Turning my head, I saw a beautiful buck mule deer gazing fixedly down at me, from a distance of not more than forty yards. Its attitude betokened intense curiosity mingled with apprehension, and its large dark eyes seemed riveted

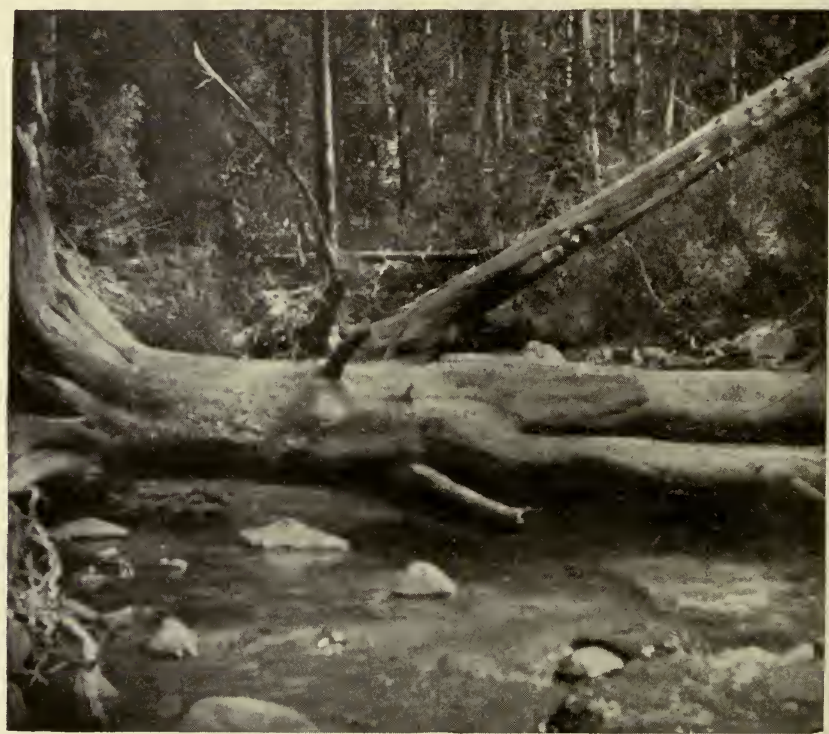

Good Wapiti Ground in the Early Autumn

upon me in a gaze expressive both of fear and hope, fear lest I should prove dangerous, hope that I might not.

As I raised my rifle and looked at those appealing eyes, I was for an instant conscious of feelings altogether out of place in a hunter's breast. It seemed a shameful thing to take the life of this trustful brute, 
and I half wished that he would bound away and only give me a running shot. However, he never stirred till my bullet struck him full in the chest. Then he came rushing close past me down the hill, but did not roll over dead, though shot right through the heart, till he had run a distance of nearly a hundred yards. He was a beautiful creature, very thick-set and heavylooking, though symmetrically built. He had already donned his autumn coat of soft grey with a very conspicuous white rump. The upper half of the tail was white, and here the hair was short; but the lower part was deep black ending in a small brush. In the blacktailed deer of British Columbia the whole tail is black. Otherwise this species seems to nearly resemble the mule deer, though its ears are smaller, I believe. In the mule deer, the ears are very large - actually larger than in its giant cousin, the wapiti - and very hairy and fluffy inside. The white patch on the hindquarters, which extends to a little above the root of the tail in winter, is very conspicuous when a deer of this species is going straight away from one, but is scarcely noticeable in a broadside view. The buck I had just shot carried a rather small but pretty head of nine points. He was in splendid condition (as were all the mule deer bucks I subsequently shot), the fat over his loins and rump being quite an inch and a half in thickness. He had, too, a lot of inside fat. I have never seen any animals put on so much fat over the loins as do the mule deer bucks in the Rocky Moun- 
tains during the autumn months. Their meat is, too, as good as it is possible for meat to be, before it becomes rank, as it does towards the end of October. Of the nine mule deer bucks I have shot, I weighed two. One of these, a very large and heavy stag - the heaviest, I think, that I killed - weighed I 7 stone, 4 lbs. clean, after having lain a night out on the hillside. The other, which was certainly smaller and lighter than at least two of those which I did not weigh, weighed I 5 stone, $4 \mathrm{lbs}$. clean, after having lain out for two nights.

Although bighorn sheep were thinly scattered over the mountains in which we were hunting, I never came across a ram, though when hunting for wapiti close up on the edge of timber line, I was often able to look with the glasses over ground where Graham said one might expect to see sheep. One day, however, on returning to our high camp on the top of the pass, my wife told me that our cook had during a climb up the mountain in the morning seen some animals which he was not able to make out, but which he thought were deer. We had not seen a head of game for some days before this, and were just out of meat, so the following morning I went out alone, determined to try to find the animals that our cook had seen the day before, and bring one of them back to camp. Following the directions given me, I came, after an hour's climb, on the tracks of the animals our cook had seen the previous day, and saw at once that they had been 
made by wild sheep, and about an hour later sighted the animals themselves. They were right on the top of the mountain, which presented the appearance of an undulating grassy plain, broken by stony ridges. With my glasses I counted thirteen sheep, and was disappointed to find that they were all ewes. They had evidently been living on this mountain for some time, as their tracks were everywhere to be seen. As the ground was very open and the sheep were constantly moving, feeding along against the wind, I found it very difficult to approach them. At length, however, I managed to kill one, - a fine big old ewe with only one horn, - and as it was still early, resolved to return to camp to get a horse, in order to carry the carcass in whole, for the ascent had not seemed too steep for a western American pony to negotiate.

I got back to camp soon after midday, and returned to the dead sheep in the afternoon, accompanied by my wife and Graham. We got the horses up without much difficulty, though we had of course to lead them in all the steep places. The top of this mountain, one of the Shoshone range, I think - could not have been more than thirteen thousand feet above sea level, probably not quite so much. It was a gloriously fine day without a cloud in the sky, and the air was keen and bracing. When not making any particular exertion, neither my wife nor I experienced any inconvenience from the rarefaction of the air; but after firing at the sheep in the morning I had found, when trying 


\section{I96 SPORT AND TRAVEL}

to make a little run, that the exertion made me puff and blow dreadfully; in fact, I had found that I simply could n't run.

The view from the spot where the sheep had met its death was simply glorious, masses of rugged moun-

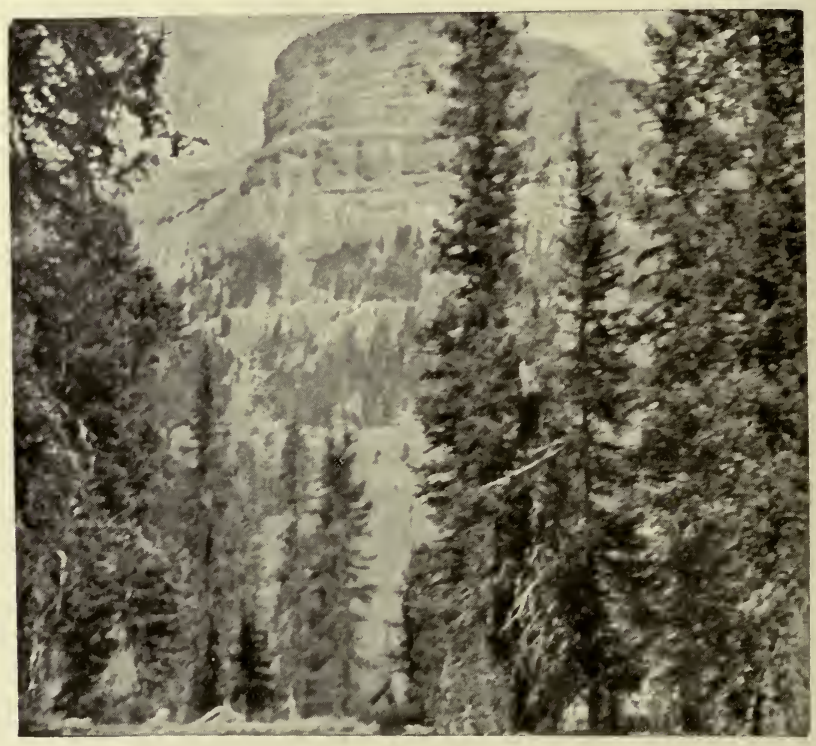

View in Rocky Mountains near the Head of the South Fork of the Stinking Water River

tains lying all around in every direction as far as the eye could reach, amongst them the jagged peaks of the Teton range, which, owing to the clearness of the air, seemed quite near at hand, though in reality they were many miles distant, standing in bold relief against the clear blue sky. One thing that I missed 
in this, as in every other view I ever had in the Rocky Mountains, was the sight of vultures, lammergeiers, and eagles circling slowly yet majestically overhead, or sweeping swiftly on motionless wings along the rocky faces of the mountains, as one sees constantly in all the mountain ranges of eastern Europe and of Asia Minor. In the Rocky Mountains, however, vultures and lammergeiers are non-existent, and eagles very scarce; at least, I did not see more than three or four during the time I was hunting there, and these were all of one species, smaller apparently and a good deal darker in plumage than our golden eagle.

On October I, we recrossed the high divide between the Wind Rover country and the South Fork of Stinking Water. It rained hard all day long, and we got thoroughly soaked through, whilst the steep mountain path we were following became in places very slippery for the horses. However, the tarpaulins kept our blankets and spare clothes dry, and after we had pitched the tents in a sheltered spot, and made up big fires, we soon got warm and comfortable again. During the night it turned a little colder, and the rain, which still kept falling at intervals, changed to snow on the mountains above us, the glittering white mantle extending to within a few hundred feet of the valley in which we were camped. The sight of snow raised our hopes, for snow is the one thing which the amateur wapiti hunter in the Rocky Mountains learns to pray for, as after having walked and climbed for 
perhaps days together without ever seeing a wapiti or a deer, or even the fresh track of one, and perhaps showing, however involuntarily, by his face, something of the disappointment it is impossible to avoid feeling in his heart, he will be sure to hear such words

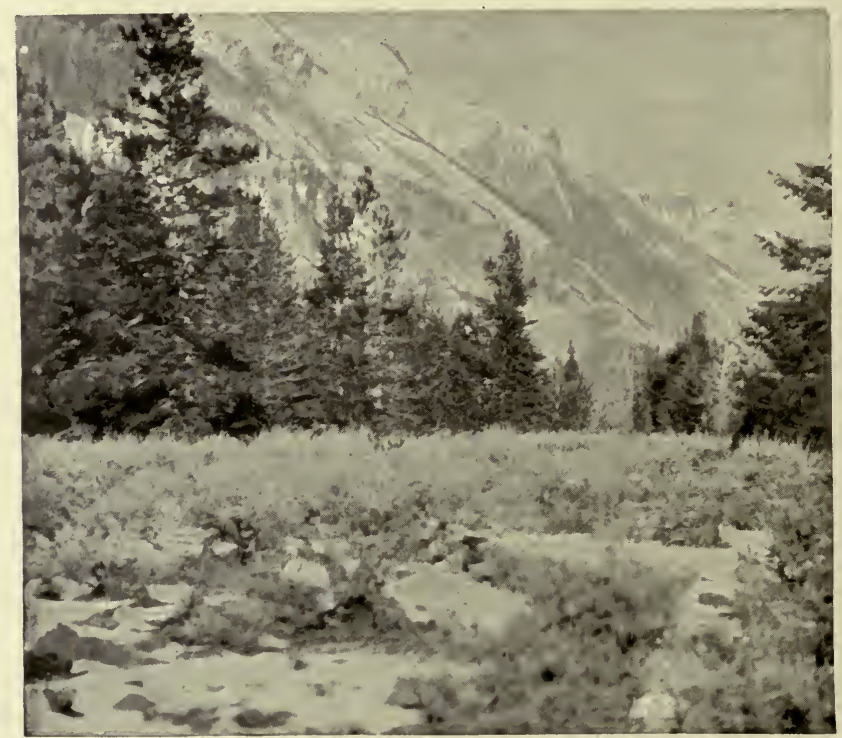

Scene in the Rocky Mountains after the First SNowfall, OCTOBER, I897

of comfort as, "Wait till we get tracking snow, and you 'll get all the elk you want, I guess," or, "The first good snow-storm will drive them out of the higher mountains, and then we shall have a chance to find them;" and so the hope of snow buoys one up and prevents bitter disappointment turning to dull despair. 
Personally, I believe in the desirability of snow for success in wapiti hunting, for although the presence of snow may be immaterial to success should one have the luck to hear the stags whistling freely, - as they always used to do, I believe, during the rutting season, - yet if they don't whistle, but only skulk ever watchful in the dense forests, and there is no new snow to aid one in tracking them and deaden one's footsteps, it is a difficult matter ever to get a glimpse of one at all.

Our success up to date had not been great. W. M. had shot a wapiti bull and a mule deer buck, whilst I had accounted for two prong-horn bucks, two mule deer (a small buck and a medium-sized stag), and one bighorn sheep ewe. Considering that one does not eat more bull wapiti meat than one can help, and that we were seven in camp (eight, counting a hungry dog), we had so far only just kept ourselves in good meat.

On October 2, I started out with Graham as early as possible into the mountains lying to the north of our camp, whilst W. M. crossed the river with Jinks to hunt along the course of a stream flowing into it from the south.

After leaving camp, Graham and I climbed steadily up the steep forest-clad slopes immediately above us, and soon got into snow which gradually became deeper and deeper as we climbed higher and higher. We were, I suppose, about one thousand feet above our starting-point when we came upon the perfectly 
fresh tracks of a small herd of wapiti, which must have passed late in the night after it had stopped snowing. We first met with these tracks on the side of a very steep hill covered with such thick pine forest that it was often difficult to see more than fifty yards in any direction. Here the snow was about six inches deep, but gradually became deeper, as the tracks led us higher up the hillside. As we zigzagged backwards and forwards, the wind was sometimes in our favour, sometimes against us, and every moment I expected the telltale snow would show us where the keen-scented brutes we were following had winded us and dashed off. Luckily, however, they were farther off than I had imagined, and presently they led us on to the top of a high shoulder of the mountain. Here the snow was quite a foot in depth. They now held along the top of the shoulder towards the main range, always through thick forest. The wind was just as bad as it could be, and at this time I had but little hope of ever seeing our game.

At last the wapiti, always ascending, brought us to the verge of timber line, their tracks leading out into a great, open valley quite devoid of trees. On our left was a ridge on which grew a few scattered pines; but just where this ridge joined the main range at the foot of a very precipitous rock wall, there was a thick cluster of tallish pine-trees, covering perhaps half an acre of ground. Looking at the way the tracks were heading, and the inhospitable 
nature of the surrounding country, Graham and I both felt sure that the wapiti were either lying in the shelter of this piece of timber (the highest in this part of the mountains) or else that they had crossed the ridge and descended into the valley beyond. If they were in the timber and we approached it by following on their tracks, they were bound either to get our wind or to see us as we crossed the open ground. Indeed, they would probably have done both, and it was no doubt to guard against being followed that they had chosen this spot in which to pass the day, for they proved to be there sure enough. Unfortunately for them, they had not such novices to deal with as they seemed to expect. Having carefully studied the position, my companion and I now left the spoor, and, striking to the right, crossed the ridge on which the few scattered trees were growing, about one thousand yards from the thick grove of pines, towards which we made our way, well out of sight and below the wind.

When just opposite the grove where we expected the wapiti were lying, we climbed to the top of the ridge. Almost immediately I saw the head and ears of a wapiti hind amongst the trees. She was looking full at me, and did not take long to size me up, for she swung round and disappeared instantly. I ran forward as hard as I could, making sure I was going to get a shot, as the ground was open all round the cluster of trees. Very soon I saw a hind break cover 
and make off down the slope of the ridge up which we had just come. I halted immediately, and stood perfectly still behind a tree just on the crest of the rise, and I don't think she saw me. She was soon followed by six more hinds and calves, all trotting slowly one behind the other in single file; but for some time no stag showed himself, and I began to think the cunning brute - for certain signs had assured us, as we were tracking the herd, that there was a stag with them - must have broken back and dashed off alone across the open ground on the other side of the grove of trees. But no; after a few seconds of agonising suspense a noble-looking monarch of the mountains walked slowly from the shelter of the pine-trees and followed the ladies of his household, who had now halted about fifty yards down the slope. When they saw him, they came trotting along the face of the slope, passing in quite open ground not more than sixty or seventy yards below me; and as the stag followed them, I waited until he came past, though he had been well within shot ever since he came out from amongst the trees. As he did not know where I was, and probably had not the least idea why the hinds had trotted off, he came along very leisurely, looking magnificent, for although his antlers were but moderate in size, there were no others of larger proportions near to dwarf them, and even a very ordinary wapiti stag, seen at short range in its native wilds, is a glorious sight to look upon. 
I let him get a little past me, and then put one of Holland's peg bullets just behind his shoulder, low down. I saw by the convulsive rush forwards that he made, that he was struck through the heart, but I did not expect so large an animal to collapse so quickly. He had not gone twenty paces after being hit, when he fell suddenly right on to the prostrate stem of a large tree, which did not, however, stop him, as the impetus of his fall carried him over it, and he then went sliding at a terrific pace down the steep snow slope below, and disappeared from sight almost immediately.

Following as rapidly as possible, we found that he had slid down the steep snow slope for about fifty yards without coming against any tree that might have brought him up, and then gone down an almost precipitous rocky gully. Standing at the top of this and looking downwards, my heart died (as the Kafirs say) for I did not think it possible that a dead animal could fall down such a place without smashing his horns all to pieces. The same thought struck Graham, too, for he remarked, "Well! I be doggoned; he won't have much horns on him when he gets to the bottom of that." The gully down which he had slid was very rocky and so steep that we had the greatest difficulty in climbing down it. We ultimately found the dead wapiti at the bottom of it, quite five hundred feet below the spot where he had fallen dead and commenced his slide. Strange to 
relate, only a few inches were broken off the end of one of his antlers. Otherwise they were uninjured. His body, however, had been terribly bruised, his hind-quarters having scarcely any hair left on them. He had evidently gone down the gully hind end first, and in this way that part of his carcass had received all the heavy bumps, and his horns had only dragged behind. If he had gone down head first, nothing could have saved his horns from being smashed to pieces. Though we searched carefully, we could not find the piece of horn that had been broken off. But for this accident he would have been a very pretty fourteen-pointer of moderate size. I took the skin off his head and neck there and then, and carried it back to camp, - with my rifle it made a load of thirty pounds, - Graham shouldering the skull and horns, from which we had cut as much meat as possible.

On the following day I again hunted high up on the mountains just on timber line, where the snow still lay about a foot deep, but did not come across any fresh tracks of wapiti or deer. In the afternoon, however, whilst returning to camp, we just caught a glimpse of a mule deer buck as he disappeared round a boulder of rock on the slope of a wild ravine, along the top of which we were walking. Although the sides of this ravine were for the most part covered with dense pine forest, there were here and there open grass slopes and rocky places devoid of both grass and trees. It was on one of 


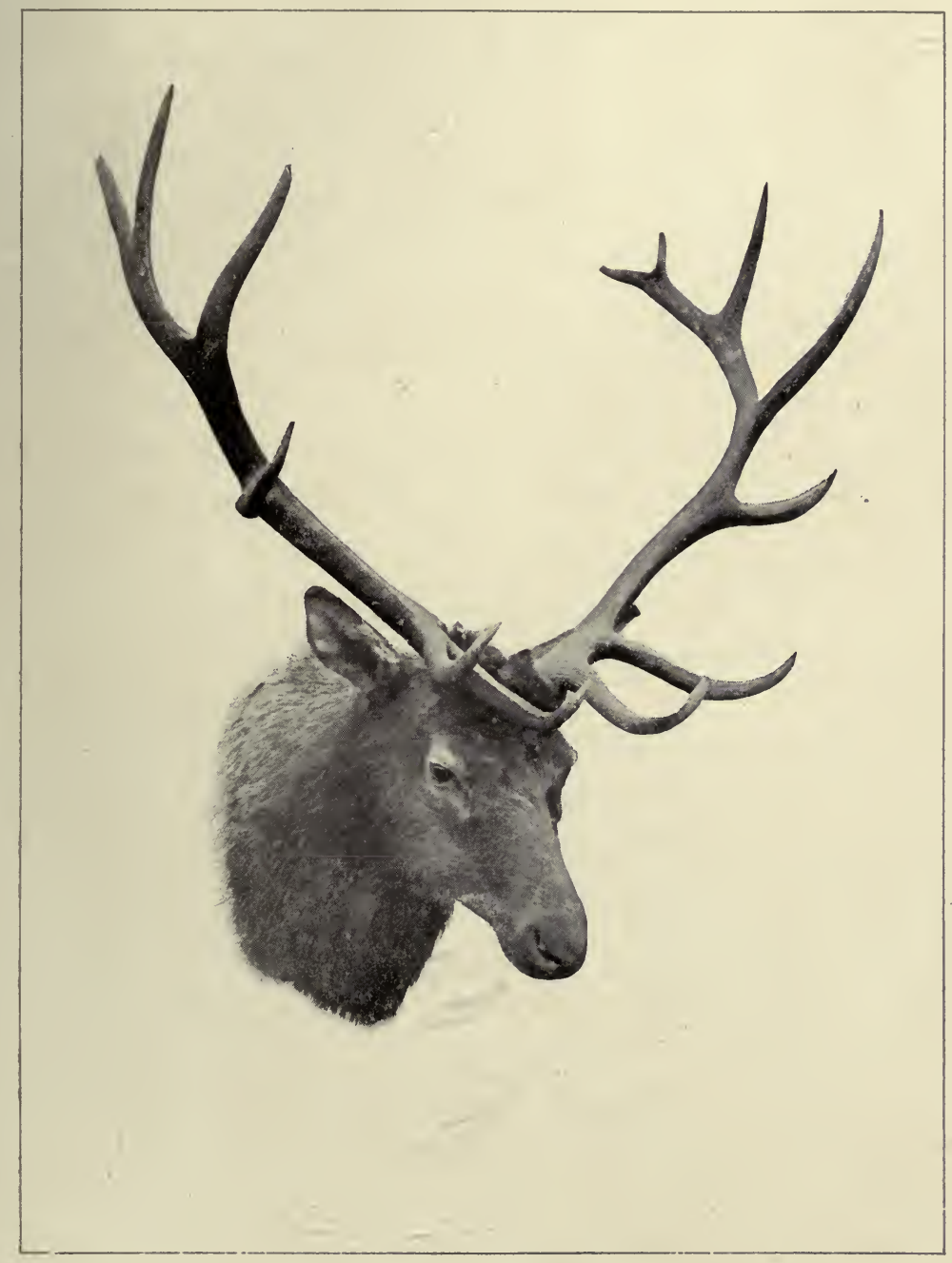

HEAD OF WAPITI

Shot near Davies' Ranch, November, 1897

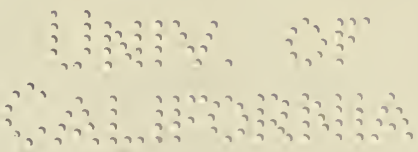



these open grassy places, from which the snow had already been almost completely melted, owing to its. having been exposed all day to the direct rays of the sun, that this deer must have been feeding or lying; but he must have heard us approaching, as we only just saw him disappearing round a boulder of rock.

The next day I went out with Jinks, and thinking that I might find this same buck deer sunning himself in the early morning, - for I had heard from Graham that at this season of the year mule deer bucks never wander about, but live very close round some chosen spot, - I made straight for the place where I had seen him the previous day. When near the edge of the ravine I advanced alone, and finally crawled on hands and knees to the top of the grass slope, and there, sure enough, I found the animal I was in search of. $\mathrm{He}$ was lying basking in the sunshine, about a hundred yards below me. At first I could only see his head and neck, but after crawling a little farther forwards, got a view of about half his body. I fired at once and hit him in the back almost between the shoulder-blades. He endeavoured to rise, but only succeeded in tumbling out of his bed and rolling down the steep slope into a cluster of pine-trees. When I got down to him he was not quite dead, so I put him out of pain with another bullet. He proved to be a fine fat buck, with an immensely thick neck, and was altogether fatter and 
heavier than the first mule deer I had killed. He carried, too, a finer pair of horns, though they were still only of moderate size. Still, such as it was, I was very pleased to add his head to my collection of hunting trophies. As I did not wish to have any of the prime fat meat wasted, I sent Jinks back to camp for a pack horse, telling him that I would clean the buck and hang all the inside fat on a tree, and then go on hunting by myself. In South Africa one packs an antelope the size of a mule deer on a horse whole, either on or behind the saddle, and it takes a strong man to get an animal of that size into position without assistance; but in America it is usual to cut such an animal in two and carry the halves, one on each side of a pack saddle, and this I knew Jinks would have no difficulty in doing alone, so when I had cleaned the deer I did not consider it necessary to wait for his return.

After climbing to the top of the ravine I walked along its edge, keeping, however, within the timber which skirted it, and only coming out of it at those points from which I could get a good view. Presently I came to a boulder of rock, which, jutting out from the edge of the timber, commanded an excellent view not only of that part of the ravine which lay beyond it, but also of the mountain-side above. I had been sitting on this boulder for some few minutes when on slightly turning my head I suddenly saw something that at once arrested my atten- 
tion, high up on the face of the mountain. Here there were many rocks amongst a scattered growth of pine-trees, but there was also something else that did not look exactly like a rock. Half of it was very light in colour, the other half very dark, but though I thought at once that it was a wapiti bull lying down, it was too far off to make quite sure of with the naked eye. I had a very powerful pair of glasses with me, and they at once revealed what appeared to be a grand old wapiti bull, lying high up on the mountain-side, in such a position that he commanded a view over a vast extent of country below him. His body was very light in colour, and his head and neck very dark. His horns looked large and widespread, and through the glasses I could plainly see the white tips to the tines. He was lying broadside to me, but had his head turned full face, as if he was looking straight at me; yet I was so far off that I did n't think he could see me. Presently I saw him (through the glasses) turn his head, and I then at once lay flat down on the rock where I had been sitting, and, rolling over and over to its edge, slid down behind it. Then I looked again, with only the top of my head above the rock, and saw that the wapiti was still lying motionless, so I made sure he had not seen me.

After having taken very careful note of the ground between us, I then commenced what I made sure was going to be a successful stalk; for though I had a long 
way to go I thought I had plenty of time, and therefore determined to go completely round my would-be victim, climb the mountain well beyond him, and come down on him from above. I did all this, and took a long time doing it, as when I got near the place where the wapiti had been lying, I advanced very slowly, taking every possible precaution not to disturb loose stones or make any noise. But at last I realised that my labour had been in vain. The wapiti was gone. He had got up and walked off quietly, whilst I was making my way towards him through the thick timber below the shoulder of the mountain.

My opinion now is that he saw me when I first climbed on to the rock in the ravine far below him, but as I was so far away did not think it necessary to do anything more than keep an eye on me, as long as I was in sight. When, however, I suddenly disappeared, and did not reappear again within a reasonable time, his suspicions were aroused, and to prevent the possibility of an accident he got up and walked off. I have been played the same trick by wild goats (Capra agagrus) in Asia Minor, and some antelopes in Africa. I was soon on the tracks of the lost wapiti, and followed them a long way, but never set eyes on that wise old beast again, for though he had never run, he had never halted; and at last I had to give him up, and had then got so far away that it was after dark when I reached camp. 
Two days later, on October 6, I again went out by myself, - the way I really prefer to hunt in the Rocky Mountains, - as noiselessness is everything there, and one man makes less noise than two. As the wapiti and deer always seemed to be high up, I ascended first of all to near the edge of timber line; but not getting any tracks in the now fast disappearing snow, crossed over a divide, and then followed the course of a thickly timbered ravine, that I knew would lead me into the main valley of the Stinking Water, not many miles below our camp. About two o'clock I got the fresh track of a wapiti bull and followed it a long way, but had at last to give it up and strike for camp. It was just getting dusk when I reached a wooded hill just above the path which I knew led up the valley of the Stinking Water to our camp about four miles distant. Having been walking and climbing since early in the morning, I was rather tired, and being so low down (comparatively) had abandoned all further hope of seeing game. However, as I was walking quickly along through the pine-trees, carrying my rifle over my left shoulder, and swinging my hat in my right hand, I suddenly came face to face with a wapiti bull. He was standing amongst some thickish timber looking straight at me. On seeing him I stopped, at the same instant dropping my hat and swinging my rifle off my shoulder; but even as I did so the wapiti swung round and immediately disappeared 
amongst the thickly growing tree-stems. I really had but the slightest chance of hitting him, but I fired a forlorn hope of a shot after him, and probably put the bullet into a tree. It was almost too dusk then to see blood on the ground amongst the pine needles, but I came back again the next morning and assured myself there was none. As I walked home in the dark, I thought what a mockery it was to have had a wapiti presented to me under such conditions. Had I come across him earlier in the day, when I was moving through the forest cautiously with all my senses on the alert, I might have seen him sooner and perhaps got a good chance. However, in the pursuit of all wary game in a forest country, there must inevitably be "many a slip 'twixt the cup and the lip," and luck will often have more to do with one's success than good management. Still "it 's dogged as does it," in hunting as in everything else; and given plenty of time, perseverance is bound to wear down bad luck sooner or later.

On October 8, I went out with Jinks. We started on horseback and rode some miles along a blazed trail, - that is, along a path which, though otherwise invisible, was marked here and there by trees from which a piece of bark had been chopped, leading up the valley of one of the many tributaries of the main stream on which we were camped. Presently we reached a point beyond which the ground was very much cut up by steep-sided gullies, and here 
we left our horses (after having hobbled them and removed their saddles) and proceeded on foot. Having climbed to the top of a little ridge, we halted to take a look round. Jinks, who had the glasses, had just said, "I think I can see sheep," when I, too, saw the white rump of an animal, as it moved amongst some small scattered pine-trees about four hundred yards away to our left. Soon I made out two more, one of which was lying down; but they were too far off to be seen very distinctly with the naked eye. Jinks, however, now confidently pronounced them to be sheep, but said he feared they were either ewes or young rams. Taking the glasses from him, I was obliged to come to the same conclusion; but there was still a chance that there might be a ram somewhere near the animals we could see, hidden from view by a tree or some inequality in the ground, and we were just preparing to commence a nearer approach when for some reason or other the sheep began to come nearer to us. Something appeared to have startled them, though I don't know what it could have been unless it was the sight of a lynx or a puma. We soon saw that there were five sheep all together, and that they were all ewes. The slope just above us was very steep and rocky and scantily covered with pine-trees for a distance of perhaps three hundred feet, but above this there rose a sheer wall of rock, and it was just along the base of this that the wild sheep came. They advanced in single file, sometimes trotting, sometimes walking, but 
with many halts; and as they passed just above us, at a distance of about one hundred yards, they gave me some excellent chances, of which, however, as they were only ewes, I did not avail myself. My companion had been rather anxious for me to take a shot, urging, in answer to my objections, that the meat of the last deer I had killed was not yet finished, and that I did not want the head of a sheep ewe, that in his opinion sheep meat was better than deer meat, and would be much appreciated in camp.

In a country where game is so scarce that one only gets an occasional chance of a shot at anything at all, more self-restraint is sometimes needed, in order not to kill an animal unnecessarily, than in those parts of Africa where wild animals still abound, for in the latter country one can always get a fair amount of legitimate shooting, as one sees animals with heads worth preserving almost every day, and must kill a good deal of game to support one's native following; whilst in a country where one may hunt for days together without seeing a living animal, there is often a strong temptation to have a shot at the first beast that presents itself, even though he has n't got a head worth keeping and there is still meat in camp, for a great deal of hunting with very little shooting is somewhat dull work.

After the sheep had passed out of view, Jinks and I held on our way up the valley we were in, and had almost reached the head of the creek by which 
it was intersected, when we came on the very fresh track of a deer, which my companion at once pronounced to be an animal of unusual size. "You'd get some horns, I guess, if you could get him," he remarked, and we at once set about tracking him up. There was no snow on the ground here, and we very soon lost the tracks completely. Jinks then went off to the right to try to pick them up again, whilst I held on in the direction it seemed to me that the deer had been travelling. It was not long before I again found the tracks; and a moment later I saw the horns of the deer itself appear just above some wild currant bushes. I was now in mortal fear lest Jinks should come towards me or call out, and so disturb the deer; but fortune favoured me, and on creeping to a rock and looking over it I got a clear view of a splendid buck mule deer. He was standing in a favourable position for a shot, less than a hundred yards away from me, so I lost no time in firing. At the report of my rifle he went off in a series of leaps for about thirty yards through the wild currant bushes, then stopped, and just as I was going to fire again, rolled over. When I came up to him he was quite dead, my bullet having struck him rather low behind the shoulder, torn a large hole through the side of his heart, and passed out through the lower part of the neck. When Jinks came up he pronounced him to be a very large mule deer. He was astonishingly fat and carried a fine massive head, his horns 
growing much straighter up than is usual with mule deer. After having cleaned the carcass and lifted it on to a rock, we started for camp carrying the head and neck skin with us.

The next morning we returned with the scale, and after cutting up the deer I carefully weighed each section, with the following result:-

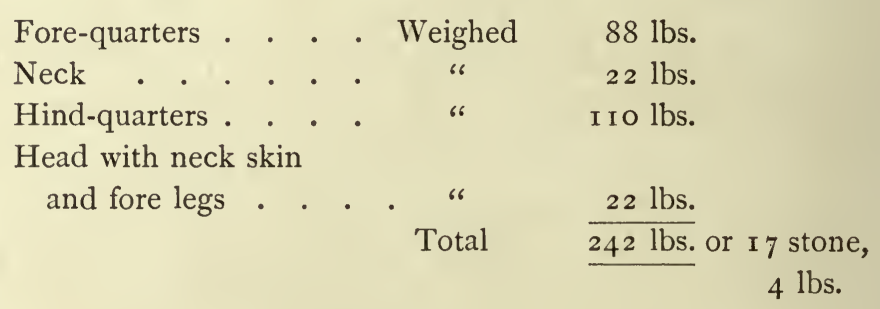

During October Io and I I, I saw nothing but one doe mule deer all by herself.

On October I 2 we all remained in camp, as it rained hard all day, turning to sleet towards dusk. On the following day it sleeted and snowed all day, but being tired of inactivity I went out with Graham. We found the mountain about one thousand feet above our camp covered with snow about two feet deep, and as the snow kept falling, the depth rapidly increased. We came on the tracks of five or six mule deer, that seemed to be revelling in the new-fallen snow, as they appeared to have been playing about in it, and kept constantly climbing higher and higher up the mountain-side. At last we sighted them, as having seen or winded us, they went off across an open 


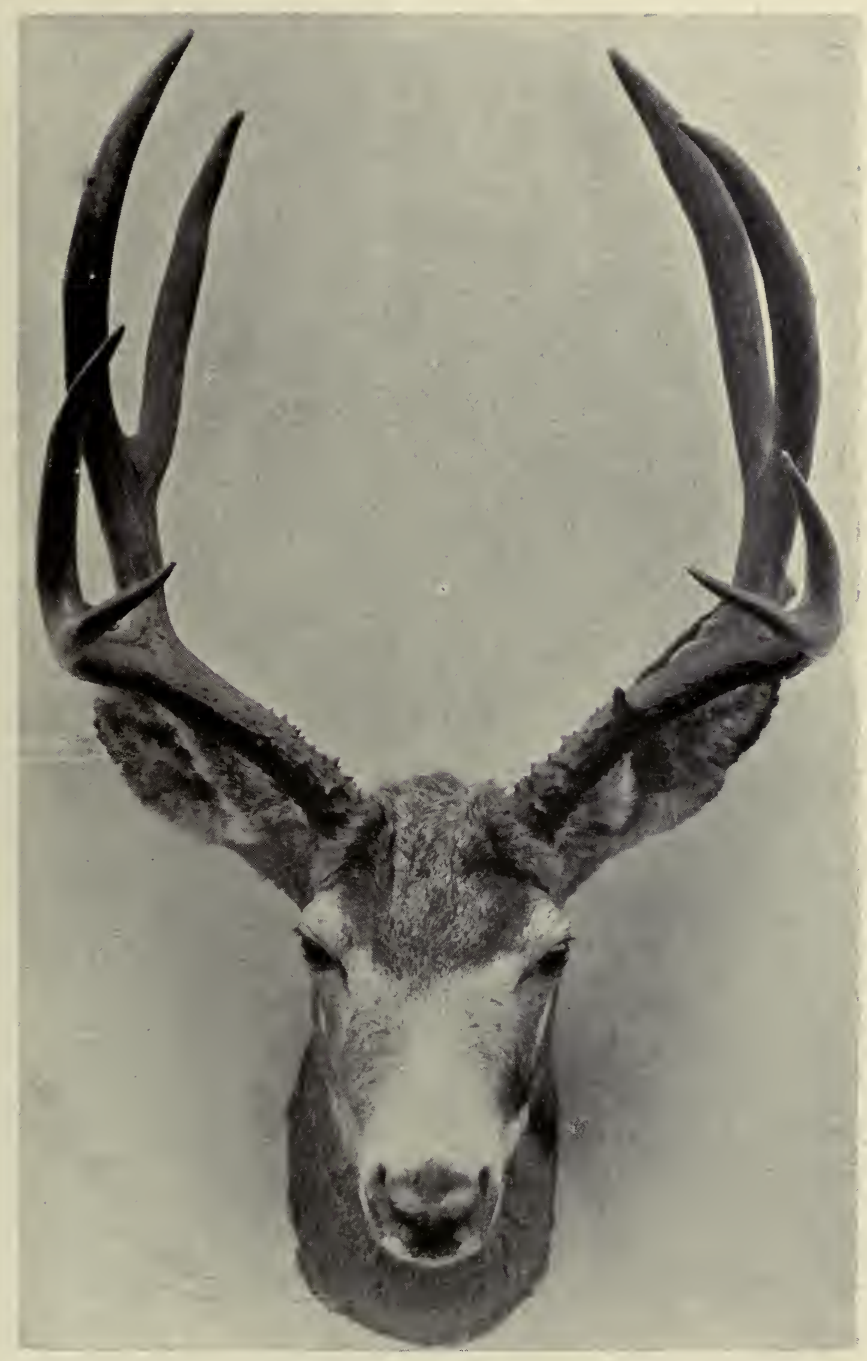

HEAD OF MULE DEER

Shot October 8, 1897

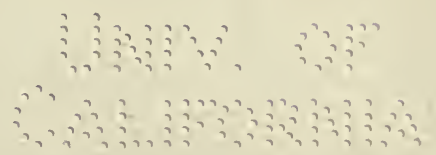



snow slope in a series of leaps. One looked much larger than the others, and though I could only see it indistinctly through the driving snow, I made sure it was a buck, and, firing at it, broke one of its fore legs with a lucky shot. We then had a long and very

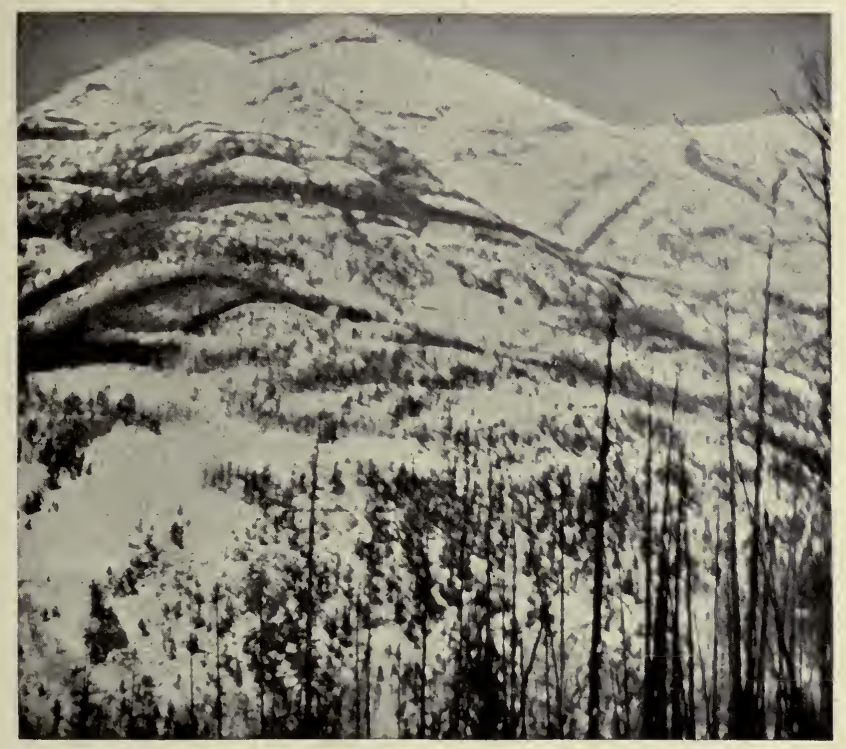

Just after the First Heavy Snow, October, I897

tiring chase after it, and at last I hit it again near the top of the mountain just over our camp. Graham's dog, Bang, was with us on this occasion, and we now set him after it. He ran it down into the valley close to our camp, and W. M., hearing the dog barking, ran out and killed the wounded animal, which was carried into camp whole. This carcass we froze, and none of the meat was subsequently wasted. 
On the morning of October 14 we found the snow about a foot deep round our camp. I went out again with Graham, but as it kept on snowing all day without a break, we returned early in the afternoon. The snow was now very deep on the hills above camp, and walking through it a very tiring operation.

It continued snowing all night and the next morning, but cleared up by eleven o'clock. Our tents were now half buried in snow and our meat was frozen solid, so that steaks had to be sawn out of a block that had all the appearance of a piece of hard wood, - a charmingly novel experience for my wife and myself, who had never before travelled in a cold country. With a small sheet-iron stove we were, however, able to keep our tent quite warm and comfortable, and though it soon cooled off at night, after the fire had gone out, to the temperature of the outside air, we were always quite comfortable under a couple of Jaeger blankets. Having no thermometer with us, we could not tell exactly how cold it was, but I don't think it was ever much below zero, which is a very enjoyable temperature in the beautiful dry air of the Rocky Mountains, as long as there is no wind.

As soon as it had cleared, I went out alone, and made my way to near the head of the creek where I had shot my second buck deer. I saw no game and no tracks, but found the snow in places so deep that the labour of getting through it was sometimes most exhausting. 
Just at the mouth of this creek we had a few days previously discovered a grave at the head of which a piece of board was still standing with the dead man's name rudely burnt into it. Hard by was a fireplace and rough stone chimney built against a rock, which had evidently formed one side of the shelter in which the occupant of the grave had passed a winter.

We heard the story connected with this lonely grave some time afterwards. The dead man had been the chief of a band of horse-thieves, that had been broken up and dispersed by the police; and being badly wanted he had fled from the abodes of men and made his way with one companion up the South Fork of Stinking Water in the dead of winter. When they thought themselves safe from all pursuit, the outlaws built a rough shelter from the weather against the rock where we had found the remains of the hearth and chimney. The rude cabin completed, the less notorious thief left his companion, promising to return in the early spring, by which time it was thought the vigilance of the authorities would have been somewhat relaxed. At the appointed time the man returned according to agreement, but not alone, for having betrayed his former comrade to the police, he was accompanied by two sheriff's officers. There appears to have been no attempt to capture the horse-thief. The informer and his companions made a stalk on to his hiding-place; and after the latter had ambushed themselves within short range 
amongst a convenient cluster of pine-trees, the false friend walked forward and called on his old companion by name. The latter, recognising his voice and suspecting nothing, at once came out to meet him, but had not advanced many yards before he was shot dead by the ambushed officers of the law. That is the story as we heard it, but whether it is all or only partly true, is more than I can say.

But lonely though the outlaw's grave may be, it lies at any rate in a lovely spot, over which the glorious mountains will keep guard, and the free winds of heaven blow fresh and sweet for evermore.

On October I6, I had a very tiring . walk, - eight hours' continuous wading through snow. I tracked a buck deer for five solid hours without overtaking it, and whilst doing. so came on three does, with which of course, not being in want of meat, I did not interfere. On getting back to camp I was very pleased to find that W. M., who had had no luck at all lately, had shot a "wapiti bull," with a well-shaped head of eleven points and measuring forty-six inches along the beam.

On the following morning, Sunday, October I 7, we moved camp lower down the main creek. It was a wretched day, fine snow falling almost constantly. Knowing that we were going to camp at the mouth of a large creek known as East Fork, I rode on ahead, and after crossing the main stream tied my horse to a tree, and hunted up the above-named tributary. I 
soon got fresh deer-tracks, and there were so many of them that I thought there was sure to be a buck amongst them, though in the snow I could not distinguish between the tracks of bucks and does by the relative size of the footprints. Mule deer appear to

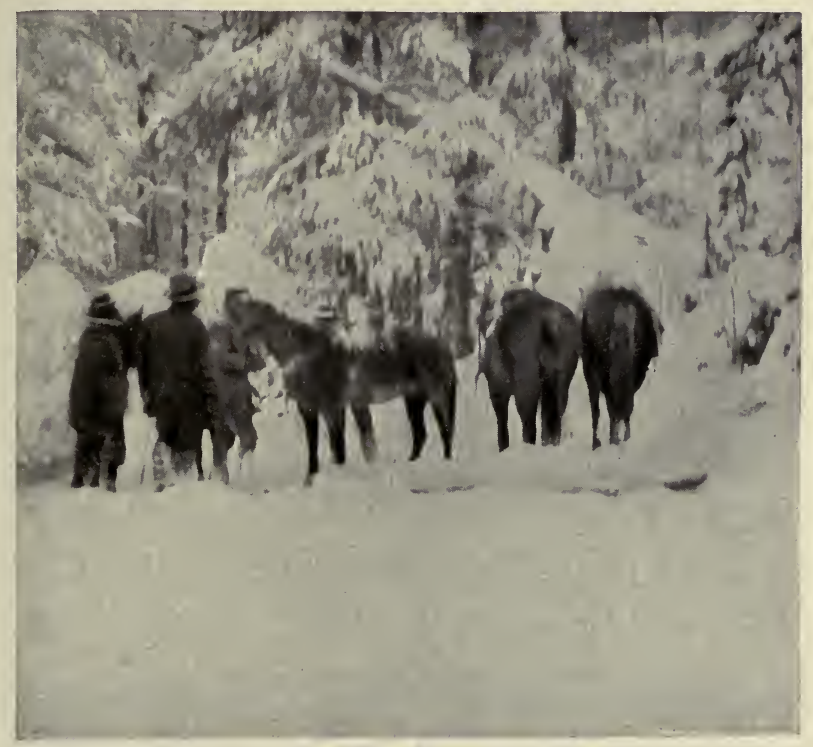

Striking Camp in the Snow, Rocky Mountains, October, i897

feed at this time of year more on the leaves of a little shrub, which grows in patches on the hillsides but only attains to a height of a foot or eighteen inches, than upon grass. These little bushes they evidently first scent, and then dig clear of snow. Mule deer always seemed to me to revel in snow, but when it gets really deep Graham told me they were 
very fond of following up a herd of wapiti, in order to take advantage of the clearances made by the more powerful animals in search of food.

I had followed the mule deer very cautiously for about an hour, never moving without first carefully scanning the ground in front of me, when I suddenly saw a telltale white rump move amongst the pines, about a hundred yards ahead. Sinking down in the snow I crept forwards to the prostrate trunk of a fallen tree, and then looked cautiously over it. I could see five deer, all does and fawns, but I knew there were others on ahead, and perhaps a buck amongst them; so I crept back again until well out of sight, and then ascended the hill to my left and came down on the deer from above. I just met them as they had apparently done feeding and were going up the mountain to take up a position for the day in the deep snow. I soon saw there was no buck amongst them, and as I did not care whether they saw me or not, I stood quite still between two trees, holding my rifle under my arm. One by one the unsuspecting creatures passed me in single file at a distance of not more than twenty yards. Each one in turn looked at me curiously, but without the slightest trace of alarm, and I have no doubt they took me for a tree, as there was no wind and I remained absolutely motionless. There were ten of them all together, all does and fawns. An old doe brought up the rear, and as she passed she looked full 
at me, and stretching out her head gave vent to a cry something like that of a young calf. It was evidently a call to her own fawn, for I heard an immediate answer from the forest, into which the foremost members of the herd had already disappeared. I fancy it must be rather exceptional to hear a mule deer make any kind of sound, as Graham told me that the bucks neither roar nor whistle nor call in any way during the rutting season, and he had always thought that the does were equally silent. After I had got clear of the mule deer I went on in search of wapiti; but though I found some pretty fresh tracks and followed them a good distance I did not see any of the animals themselves.

On reaching camp just as it was getting dark, I found that my wife and all the other members of the party had had a very interesting experience. They had just emerged into an open space opposite the mouth of the East Fork Creek, where it had been arranged that we were to camp, when a band of wapiti appeared on the bare mountain-side to their right and not more than four hundred yards away from them. They were walking along in two lines through the deep snow, and numbered seventeen altogether, - fifteen cows and calves, one big bull and one smaller one. Just then my horse, which was standing tied to a tree on the other side of the stream, caught sight of his fellows and commenced to neigh, and every time he neighed the big bull, thinking it was a challenge to 
himself, answered and bade defiance to all the world. The whole herd soon caught sight of the cavalcade, but being a good way off and well above it, they showed no signs of alarm, but walking slowly forwards soon disappeared in the pine forest. W. M. went after these wapiti, but was not fortunate enough again to catch sight of them. He could not follow them because of the wind, and so had tried to get in front of and head them off. He must have just missed them, however, in the thick timber, and it was then too late to repeat the experiment. I, too, could only just have missed seeing this herd of wapiti on my way home, and must certainly have been within two hundred yards of them, but in the dense forest we were mutually unconscious of one another's proximity.

That evening we discussed the chances of coming up with the wapiti and getting a shot at the big bull on the morrow. Graham did not think that the fact of their having seen the pack horses would cause them to travel far, but he feared they might have winded either W. M. or myself when we were close to them, in which case his opinion was that they would travel so far during the night that it would be impossible to overtake them. We then had to decide who was to follow them. W. M., who is the most unselfish fellow in the world, insisted that I should do so, and refused to toss up about it, urging that as he had killed two wapiti and I only one, it was I who ought to take this chance, if chance there was. Finally it was decided 
that I should go alone - the way I love to hunt - on the tracks of the wapiti, whilst W. M. and Graham should try a gorge coming down from the mountains to our left.

I was up early the next morning, October i 8 , and after a good breakfast put a bit of deer meat in my pocket and started out after the wapiti, making use of a horse to cross the river, which Graham, who accompanied me so far, then led back to camp. I soon got on the tracks of the wapiti, which presently brought me to the same hillside where I had found the mule deer feeding on the previous day. Here they had evidently fed for a long time, as they had scraped a very considerable area of ground free of snow, not in one continuous stretch, but in numbers of small patches, each patch having been cleared by one animal or the united exertions of two or three working together. I fancy they must have been feeding on this hillside not more than three miles from our camp - for the greater part of the night. After leaving it, they had gone down to the creek, - the East Fork, and after crossing it had climbed the side of the mountain above.

Fording the creek did not add to my comfort, as the water was icy cold and came above my knees. I had followed the wapiti for an hour or so, along the mountain-side high above the creek, and was just rounding a shoulder, divided by a deep ravine, from another portion of the mountain, when I saw some- 
thing move amongst the scattered timber below me; and the next instant made out three mule deer does, following slowly on the tracks of the wapiti, and feeding wherever these latter animals had scraped away the snow. Then I saw what I took to be a mule deer buck, as he came from behind the does, and I saw that he had horns. I only got the barest glimpse of these, however, as he immediately put his head down behind a bush to feed.

Looking across the ravine, I could see trails in the snow leading round the opposite shoulder of the mountain, and took them to be the tracks of the wapiti I was following, which I judged were therefore still a good way on ahead. What I thought was a good mule deer buck was well within shot; and though I could only see a small part of him, that part was the vital portion of his body lying just at the back of the shoulder. I wanted a few more good deer-heads, and so quickly determined to fire just one shot, and then go on after the wapiti; but the moment I fired, though the thud of the bullet assured me it had found its billet, I realised the mistake I had made. The mule deer does went off in a succession of leaps, but the animal, only a portion of which I had seen feeding amongst the bushes close to them, raising its head rushed forwards through the snow, and to my intense vexation revealed the form of a very young wapiti bull with little spike-horns. Nor was this all, for I immediately saw some dark forms passing rapidly 


\section{SPORT AND TRAVEL}

amongst the pine-trees on the farther side of the ravine. The whole herd of wapiti had only been about a hundred yards in front of the mule deer, in whose company the spike bull, curiously enough, had remained behind all by himself.

On being disturbed by the shot, the wapiti commenced climbing straight up the mountain, through such thick-growing timber that I could only get occasional glimpses of them, and for some time I could not see anything but cows. Presently, however, I caught sight of the horns of a bull bringing up the rear of the herd, and keeping my eyes on him saw him halt. He was then just within the edge of a rather thick patch of timber, but he soon walked out into a more open place and stood looking back into the ravine below him. He was now broadside to me, and I judged him to be between two hundred and three hundred yards distant. I was already sitting down in position for a shot, so putting up the second sight and taking rather full, I fired as quickly as possible, and heard the bullet tell, as the great stag, plunging forwards, disappeared amongst the pine-trees. I had hardly got another cartridge into my rifle when I saw another stag climbing upwards amongst the trees, and the glimpses I had of him made me think he carried a finer head than the one I had just wounded, but I could n't get a shot at him, and he soon became entirely lost to view. The unfortunate spike bull, let me here say, had only run about fifty 
yards before rolling over dead. I went down to look at him before taking up the spoor of the wounded bull, and found he had got the bullet right through the lungs. I felt and still feel the keenest regret at having slain him so needlessly through a stupid mistake.

On climbing up to the place where the bull had been standing when I fired at him, I soon found spots of blood on the snow. The wounded beast had first gone off along the mountain-side by himself, but, always ascending, soon came round to the tracks of the rest of the herd, which he then followed straight up the mountain-side, which was here very steep, though thickly covered with pine-trees. The snow lay quite three feet deep, but was comparatively easy to get through, as the wapiti had ploughed a path for me. I didn't like my wounded bull going straight uphill, as I thought that if he were badly wounded he would have gone downhill. However, I determined to follow him as long as I could. He was not bleeding very freely, but every speck showed up very plainly on the pure white snow; and as wherever he dipped his nose in it, he left a bloody patch, I felt sure my bullet had touched his lungs.

I had got close to the top of the ridge we were on, when hearing something above me, I halted, and the next moment saw a mule deer doe coming down towards me through the pine-trees. She was closely followed by another doe with a fawn, and behind 
them came a fine buck. These mule deer must have been lying on the top of the ridge where the snow was at least three feet deep, and had no doubt been disturbed by the wapiti. I was annoyed at having shot the spike bull, and thought that possibly I should lose the wounded animal I was following, and seeing the mule deer buck so near me, determined to have his head at all events, so killed him with a bullet through his lungs. On being struck he came plunging down the hill through the deep snow, and fell dead within ten yards of where I stood. I cleaned him hurriedly, and then laying him out belly downwards on the snow, again took up the tracks of the wapiti bull. He had followed the herd to the top of the ridge, but whilst they had then turned to the left towards a still higher shoulder, he had gone down the other side by himself. He did not descend very far, however, but soon turned and held along the face of the mountain. The snow was here very deep, and I only got through it very slowly and with great labour. Presently the wounded bull turned sharp down the hill again, but only for a very short distance, when he again turned back along the face of it, taking a line just parallel to his tracks a little higher up. I soon found out what this move meant. After going back for about fifty yards parallel to his trail, he had lain down in the snow. Here there was a good deal of blood, but on examining the tracks beyond I found that he had left this bed quite slowly at a walk. I soon, however, 
came to a second bed, from which he had sprung with a plunge, and then rushed down the hill through the snow. He had, of course, either seen or scented or heard me, as I passed along the hillside above him on his trail, and had taken up such a position as to render it quite impossible for anything to come on his trail, without his becoming cognisant of it.

I have known African elephants, in districts where they have been much persecuted, execute this same manœuvre; and I find it impossible to account for such facts except on the assumption that animals possess reasoning faculties which they are capable of exerting under pressure of circumstances. According to old writers on American hunting, all wapiti were once very stupid animals. Now some wapiti, at least, have become as cunning and as capable of reasoning out the best way of taking care of themselves as a South African elephant.

After a few plunges downhill, the wounded wapiti had again turned upwards. The snow was so deep that it was not only very exhausting work getting through it, but impossible to do this at all except at a very slow pace. Presently the tracks led me again to the top of the ridge, where the wounded bull had ceased to follow the rest of the herd, but from here he had mounted to a still higher shoulder of the mountain, and late in the afternoon he led me back to the herd once more, either by accident or design. I first saw the heads and ears of three hinds. They 
were lying down in such deep snow that their bodies were quite invisible, only their heads and necks showing above the surface. As I caught sight of them they too saw me, and getting up trotted downhill through the snow. At this moment I heard a sort of grunt below me, and then saw a few more wapiti hinds coming up towards me through the pine-trees. Then I saw the head and horns of a stag appear, but he was going along the hillside, or rather climbing it obliquely. He was within shot, but I could only see his head and horns, as his body was hidden by a swell in the ground.

I now made the most frantic efforts to get nearer to him. I think he must have seen me; but the snow was so deep that he could only move slowly through it, whilst I could scarcely move at all, in spite of the most desperate exertions, which, as I was probably ten thousand feet above sea level, made me pant so much that I thought I should not be able to hit anything smaller than an elephant. I managed, however, to gain the crest of a piece of rising ground from which I had only been a few yards distant, and could then see about half the body of the wapiti stag, and, though fearfully unsteady, managed to put a bullet into him.

Just as I fired I saw a second and smaller wapiti stag coming up the hill behind the first. A glance assured me it was the animal I had wounded in the morning and followed all day, as he held his mouth open and halted with his head down just as I saw him. 
However, I did not now pay much attention to him, as I wanted first to secure the larger animal in front. My first shot, however, had pierced his lungs, and he came to a halt very soon after he was hit. I did not know at the time whether I had hit him or not, for although I could see that he had halted, I could only see his horns, as immediately after I got my shot at him his body again became hidden by the contour of the ground. I now renewed my efforts to get a few yards nearer to him through the snow, but when I got a view of him I did not fire, as I saw he was done for. Suddenly his legs gave way beneath him, and he came rolling down the steep mountainside close past me, and would most certainly never have stopped till he had reached the bed of the East Fork, some fifteen hundred feet below, had he not presently been brought up by a big pine-tree. Curiously enough, he slid to within ten yards of the stag which had been first wounded. This latter was now so weakened by loss of blood that he could move no farther through the deep snow, and he now lay down.

When I moved down towards him he tried to get on his feet, but was unable to do so, and I then came close to him and killed him with a bullet through the lungs. After having been first wounded he had fled before me, until his strength had altogether failed, and his legs had refused to carry him any farther. To have killed two wapiti stags within ten yards of each other was certainly a very suc- 


\section{SPORT AND TRAVEL}

cessful termination to a long day's hunt, and was one of those strokes of luck which atone for many blank days. The stags were both twelve-pointers; the larger animal a fairly good one, the smaller not much to boast of.

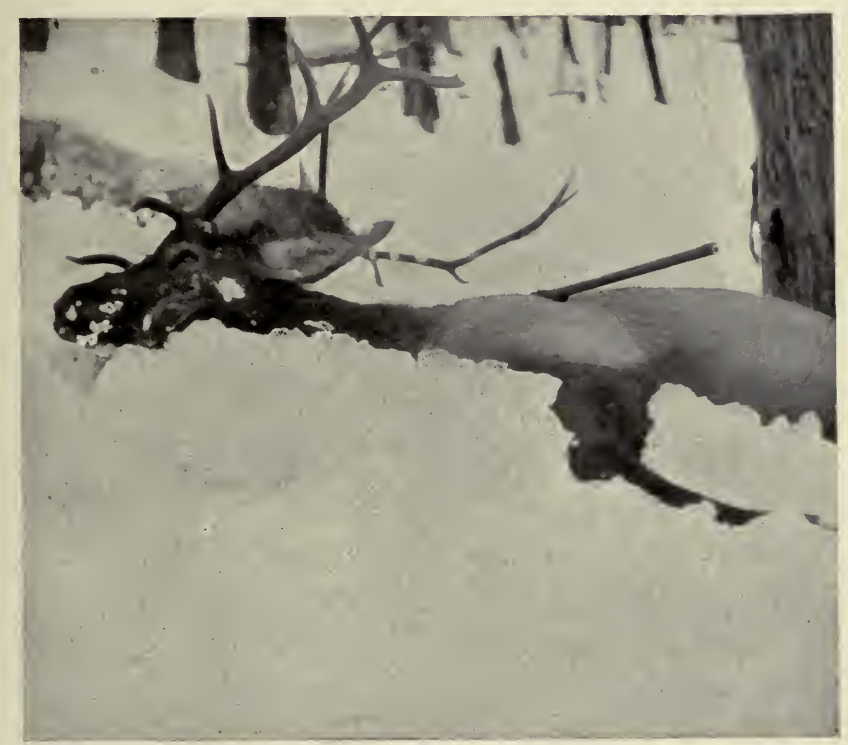

Young Wapiti Bull shot in the Deep Snow, October, i 897

It was now getting late, and although I was at no great distance from camp - for the wounded wapiti I had been following for so many hours had led me in a circle - the deep snow made it difficult to move at anything but a slow pace. I knew the snow was not so deep in the valley of the East Fork, so I first went straight down the mountain, and reached the bed of 
the creek pretty quickly, as it is much easier to get down a steep hillside covered with snow than to climb up it.

I had not gone half a mile along the creek when I suddenly saw a mule deer buck on the hillside above me with, I thought, a fine head. He was standing about one hundred yards away, half facing me, and gazing steadily in my direction. I fired at him immediately; and though he turned, and dashing away was lost to sight very quickly amongst the trees, I felt sure I had hit him, and did not think he would go very far. And so it proved, for I found him lying quite dead, not far away, my bullet having struck him at the point of the left shoulder, and torn a big hole through his heart. He was a prime buck in splendid condition; but though one of his horns was quite handsome, the other was malformed, and spoiled what would otherwise have been a fine head. By the time I had cleaned the carcass and laid it out on the snow, it was getting dusk, and as I was still some miles from camp, I did not get there till long after dark. This was the best day I had in the Rocky Mountains, and a very tiring one, too, owing to the depth of the snow on the higher parts of the mountains, though I had walked quite a small distance in mileage.

On the following day Graham and I went and fetched in the wapiti heads and the carcasses of the mule deer with pack ponies. We had to leave the ponies near the creek, and then climb the mountain 
to where the two wapiti were lying, and then find the deer, and it was late when we got the heads and neck skins of the former and the carcasses of the latter down to the ponies. We did not carry them, but slid them down the steep mountain-side on the snow. They never went far at a time before being stopped by a tree. The carcasses of the wapiti were afterwards used by a trapper for bait.

The next morning, October 20, I again went out alone, and, coming on some fresh wapiti tracks, followed them, and came nicely up to seven hinds in rather open ground, high up the mountain-side. There was no bull with them, however, so I did not interfere with them.

On October 2 I, I went out with Graham, and we had not ascended the valley of the main river above our camp for more than a couple of miles when we came on the track of a wapiti stag, which seemed to have passed the preceding evening. We soon saw that there was something wrong with one of his fore legs, which was either broken or injured in such a way that he could not put his weight upon it. Now one might think that it would be a pretty easy matter to track up and overtake in deep snow so heavy an animal as a wapiti stag. I certainly thought so when we first found his track, but gradually became undeceived.

After an hour's tracking - always going uphill - we came to a place where the disabled beast had 
lain down during the night, and from which he had probably only risen at day-dawn. He had chosen his resting-place with wonderful cunning, close to the top of a piece of rising ground where nothing could have approached unseen, unheard, or unsmelt. After this, he went down to the East Fork Creek, crossed it, and then took straight up the side of a detached mountain whose summit must have been some three thousand feet above the creek, and probably over eleven thousand feet above sea level, as it rose above timber line, and was now a glittering cap of new-fallen snow. I fancy that when we crossed the creek the great stag could not have been very far in front of us, and must have winded us, though we never saw him. He took straight up the mountain; and as we climbed on his tracks, the snow grew deeper and deeper. The disabled beast now progressed in a series of bounds, always springing from his hind legs. Every bound lifted him clear of the snow, and carried him upwards over some eight or nine feet of ground. As we toiled slowly on his tracks I expected to see him standing dead beat at every instant, for I could not believe that so heavy an animal could long endure such tremendous exertion when handicapped with a broken fore leg.

Suddenly in a bit of thick timber - I was in front with my rifle held at the ready - I saw either a branch or a horn move, and knew it must be the latter, as there was not a breath of wind stirring. I 
instantly ducked down and crawled through the snow to a fallen tree, and, looking over it, could see a small piece of the rump of the beast we were following, and also a portion of its head, but every other part of its body was completely hidden by the stems of the pine-trees. Something had attracted the animal's attertion, and it was evidently standing listening. I did not care to fire an expanding bullet into its rump, and so crept out sideways along the trunk of a fallen tree, to try to get a view of its shoulder. But when I looked up again the stag was gone. Its delicate sense of hearing or sight or smell had given it warning of its enemies' near neighbourhood, and again it had struggled onwards, in a last desperate effort to shake off its pursuers. I never heard a sound, but the first few plunges of the startled brute were prodigious. He always went upwards, and Graham foretold that if he did not play out before he reached it, he would get to the top of the mountain, as he said it was much easier for a heavy animal with a broken fore leg to go uphill in a series of bounds, always taken from the hind-quarters, than to go downhill when all his weight would come on the one sound fore leg. As we ascended we went slower and slower, and took it in turns to "break trail," for we now sank over our knees at every step in the snow. For a long time I cherished the hope that the disabled wapiti would not be able to reach the top of the mountain; but after a time I began to think that 
he would, but that I would n't, for it was really most exhausting work getting through the deep snow.

At last we reached the edge of the timber, and emerged upon the shining snow-field that capped the top of the mountain. On the very highest point the wapiti had lain down to rest; and although we did not see him, he had probably seen us as we came out of the forest, and again dashed off. But now he could climb no higher, and had perforce therefore to commence the descent of the mountain. He very soon got into a very steep place, where at some former time an avalanche had swept down the mountain-side, and cleared all the trees away in its path. This open ride through the forest was very steep, but covered deep with snow, so that it was easy work for Graham and myself to get down it, but must have been a terrible strain on the disabled wapiti. We must have come down a thousand feet from the top of the mountain, when we suddenly saw him. He was lying down in the snow, on a small level shoulder of ground in the path of the avalanche, and, cunning to the last, was facing back the way he had come, so as to command a view of anything coming on his tracks. As we saw him, he must, I think, have seen us, but we were only just in sight, and must have been quite two hundred yards above him, and he was probably too deadly tired to move again until it was absolutely necessary. After the great exertions I had made I did not feel very steady, but at once sat down, 
and putting up the two hundred yards' sight fired down straight at his chest, which was, however, covered to a considerable extent by his head and face. This bullet, as we afterwards found, struck him on the lower lip, just below the teeth, broke his jaw, and went on into his chest, where it just penetrated through the skin. He at once struggled to his feet, and with a plunge got amongst the timber.

Coming down to where he had been lying, we found blood at once, and following it soon saw the wounded beast standing amongst the pine-trees utterly exhausted. A bullet through the lungs put an end to his troubles. He was a fine big bull, with a pretty, medium-sized head of twelve points. The bone of his left fore leg was broken about six inches above the knee joint. At first I thought the injury must have been caused by a bullet, but a careful examination assured me that this was not the case, as there was no sign of a bullet-hole in the skin. Then I cut the injured leg open, and found that the break had every appearance of being quite fresh, as there was no swelling or inflammation, and only a little freshly extravasated blood.

How this stag got his leg broken is a mystery to me, Graham's suggestion that he had been knocked over a cliff by another stag not seeming to me at all probable, as the rutting season was now over. After the difficulty we experienced in overtaking this threelegged wapiti, I ceased to wonder at our non-success 
in coming up with sound animals of this species once they had been disturbed. We had actually been plodding through the deep snow for six hours on the tracks of this three-legged stag before we stood over his carcass. He had luckily brought us on to the side of the mountain overlooking the main valley of the Stinking Water River, and we were only a short distance in an aerial line from our camp; but we had a difficult and even a dangerous job to get the head home, as we were separated from the valley by some very precipitous rocky slopes. However, at last we got down to the level ground, and crossing the river finally reached camp just.after dark.

The next day I remained in camp during the morning, and skinned and prepared my wapiti heads. In the afternoon I went down to the river with my wife, and between us we caught a nice lot of trout. I caught several beautiful fish, weighing about two pounds apiece, with an artificial minnow, and I noticed that they only went at the minnow when the sun was shining brightly, when of course it sparkled and glittered as it was drawn through the water. As long as the sun was obscured by clouds, they would not look at the minnow. They always rose more readily to flies, too, when the sun was shining brightly than at any other time. There is, I am glad to be able to say, a grand simplicity of character about the Rocky Mountain trout, and an obvious belief that things are really what they seem, - qualities which 
cannot fail to endear him to the non-scientific but hungry angler, for he is a beautiful fish to eat, fat, and well fed, and with delicate pink-coloured flesh.

On the morning of October 23, I again went out hunting, but finding no tracks of either wapiti or

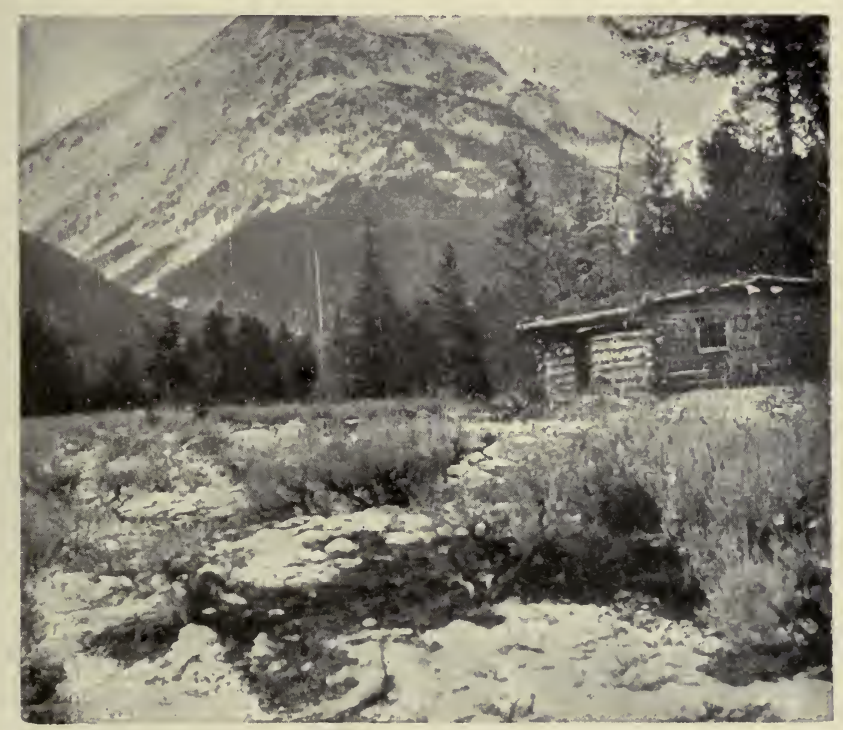

Deserted Cabin at Old Mining Camp, Rocky Mountains, OCTOBER, I 897

deer, returned to camp early and caught a lot more trout.

On Sunday, October 24, we shifted camp down the river to the empty cabins at the mining camp, ten miles above Davies' ranch. The day was dull and cloudy and threatened snow. Whilst we were fixing camp Davies turned up from his ranch, and 
stopped the night with us. He had come up to get one of the cabins ready for Colonel Cody, who was then at Cody City, where he has large interests, but whom Davies expected shortly at his ranch, bent on an outing in one of his old hunting-grounds, from which, however, most of the glory has now departed.

During Monday it snowed all day long, so that Davies could not get home, and we were unable to move out of camp. The storm continued all night and the next morning till midday, when the sun came out. Davies then went home. In the afternoon I took a turn by myself up a gully known as Needle Creek, but saw nothing but a mule deer doe and two fawns, and no tracks of anything else. On returning to camp late in the evening I found that Davies had returned, bringing a letter to W. M., which contained news that compelled him to start at once for England.

Early the following morning our kind friend left us, accompanied by one of our men and a pack horse, in order to reach Ishawood in time to catch the stage waggon, which runs daily between that place and Red Lodge station.

During the snow-storm my wife and I lived in our tent, but we took our meals in one of the cabins, which we shared with a pair of pretty little nuthatches (Sitta canadensis), a much smaller species than our English bird and with a white stripe over the eye, and several mountain rats (Neotoma cinerea), beautiful large-eyed creatures, with great bushy tails like 


\section{SPORT AND TRAVEL}

Brobdingnagian dormice. They, however, ate a lot of our stores, and took nearly all the trimmings off Davies' leather coat. In. revenge we killed two of them, and I preserved the skin of the finest for our Natural History Museum at South Kensington.

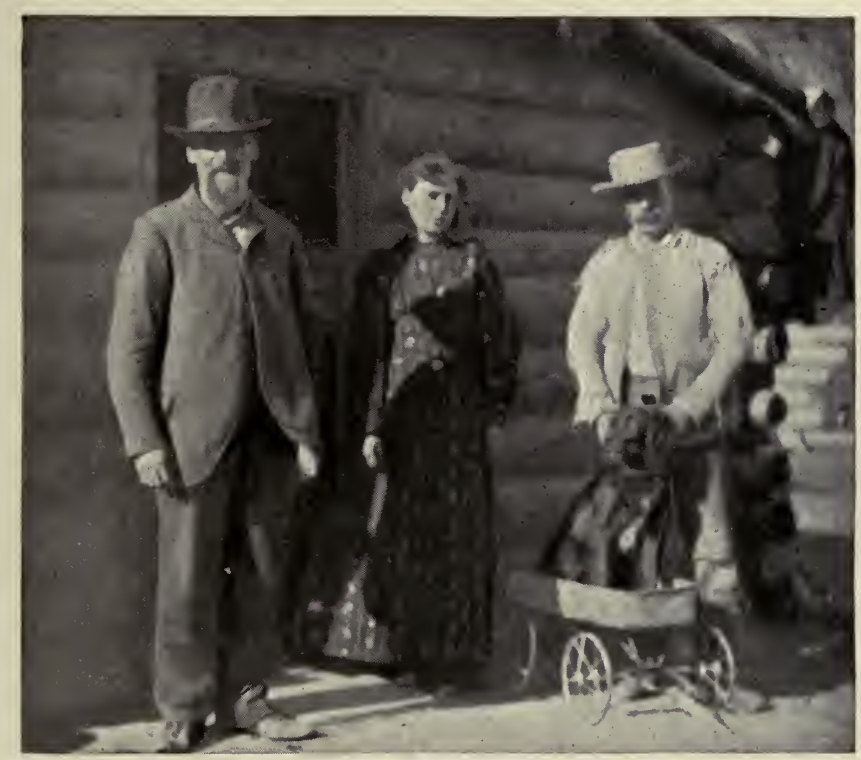

Settlers in the Far West, - Davies, Wife, and Father-in-Law

On October 28 we moved down the river and pitched our tents close to Davies' cabin. On the way I shot two mule deer, a doe, and a young buck, as Davies, who was not much of a hunter, had asked me to do my best to get him a supply of meat for the coming winter.

The next day I went up Cabin Creek with Graham, I6 
intending to look for sheep. Three or four miles from Davies' ranch there is a pretty little waterfall on this creek some twenty feet in height; and as the precipitous rock wall over which the water tumbles runs right across the narrow valley of the stream, which is here bounded and shut in on both sides by very steep cliffs, it is a somewhat difficult matter to climb from below the waterfall into the valley of the creek above it; in fact, I don't think that anything but a sheep, or a goat, or a man fairly well accustomed to rock-climbing could manage it.

Graham and I climbed to a ledge on the cliffs above the falls on the right-hand side of the creek without much trouble; but it was just about all we could do, by the help of a fissure in the rock, to get down to the bed of the stream. Immediately we did so, we struck the fresh tracks of a wapiti bull. He had evidently come down from the country at the head of Cabin Creek, where the snow must now have been very deep, with the intention of getting into the main valley of the Stinking Water River, but, finding his further progress barred by the wall of rock, running across the stream at the waterfall, had turned back again up the creek.

We had tracked him for a couple of miles sometimes in the creek bottom, and sometimes through the more or less forested slopes on either side of it, when we came to a small piece of very thick timber lying in an angle between a precipice overhanging the main 
creek and a steep rocky gorge running into it at right angles. We did not follow the wapiti's tracks into this piece of dense pine wood, but skirted it, until we reached the edge of the gorge I have spoken of above. A glance then showed us that no deer could have got down the almost precipitous sides of this gorge, and as we had not crossed a wapiti's track coming out of the timber and going higher up the mountainside, it was evident our game was in the patch of forest below us, for a sheer precipice cut off its descent to the main creek. To escape from its present position, it would have to go back again the way it had come down the creek, or come up the mountain-side. As it had already been once stopped by the precipitous nature of the country at the waterfall, I thought it would adopt the latter course, and therefore took up a position as quickly as possible from which I was able to command the hillside above the cover. Then Graham went and took up the tracks again. I expect the cunning old stag had already either heard or seen us, but feeling himself to be more or less cornered, was waiting in the cover to see what we were going to do. Graham never saw or heard him, and he did not come past me, but slipped off back down the creek again so quietly that if I had not just caught a glimpse of him going at a trot amongst the trees, we should not have known what he had done until we had learned it from his tracks in the snow. Shouting to Graham, I now 
ran and slid and clambered, as hard as I could go, diagonally downwards, until I struck the wapiti's tracks, and, Graham joining me, we followed them as quickly as we could into the bed of the creek. We had got quite close to the falls, always following the wapiti's tracks, and Graham had just said, "Well, I be doggoned, but I 'm afraid he 's beat us this time," when I suddenly spied him, standing on the face of the cliff high above us.

The poor animal, for the second time finding it impossible to pass the falls, had endeavoured to climb the mountain-side to the right of them. A steep slope, covered for some fifty feet from the water's edge with pine-trees, gave him no difficulty, but above this there was nothing but bare rock, not exactly precipitous, but still very steep. Up this he had managed to ascend for fifty feet or so, and could then apparently neither get higher nor come lower again. Looking up through the pine-trees, I saw him, and from his attitude I think he was watching us. I at once fired at him. I knew I had hit him, but he never moved, so slipping in another cartridge I fired again. Both these bullets struck him in the chest, and just missing his heart pierced his lungs, and lay together under the skin at the top of his shoulderblade, for I had fired almost straight upwards.

For a moment yet the doomed beast stood still, then, slowly lurching over, came rushing a lifeless mass down the cliff. He fell head first, and the first 


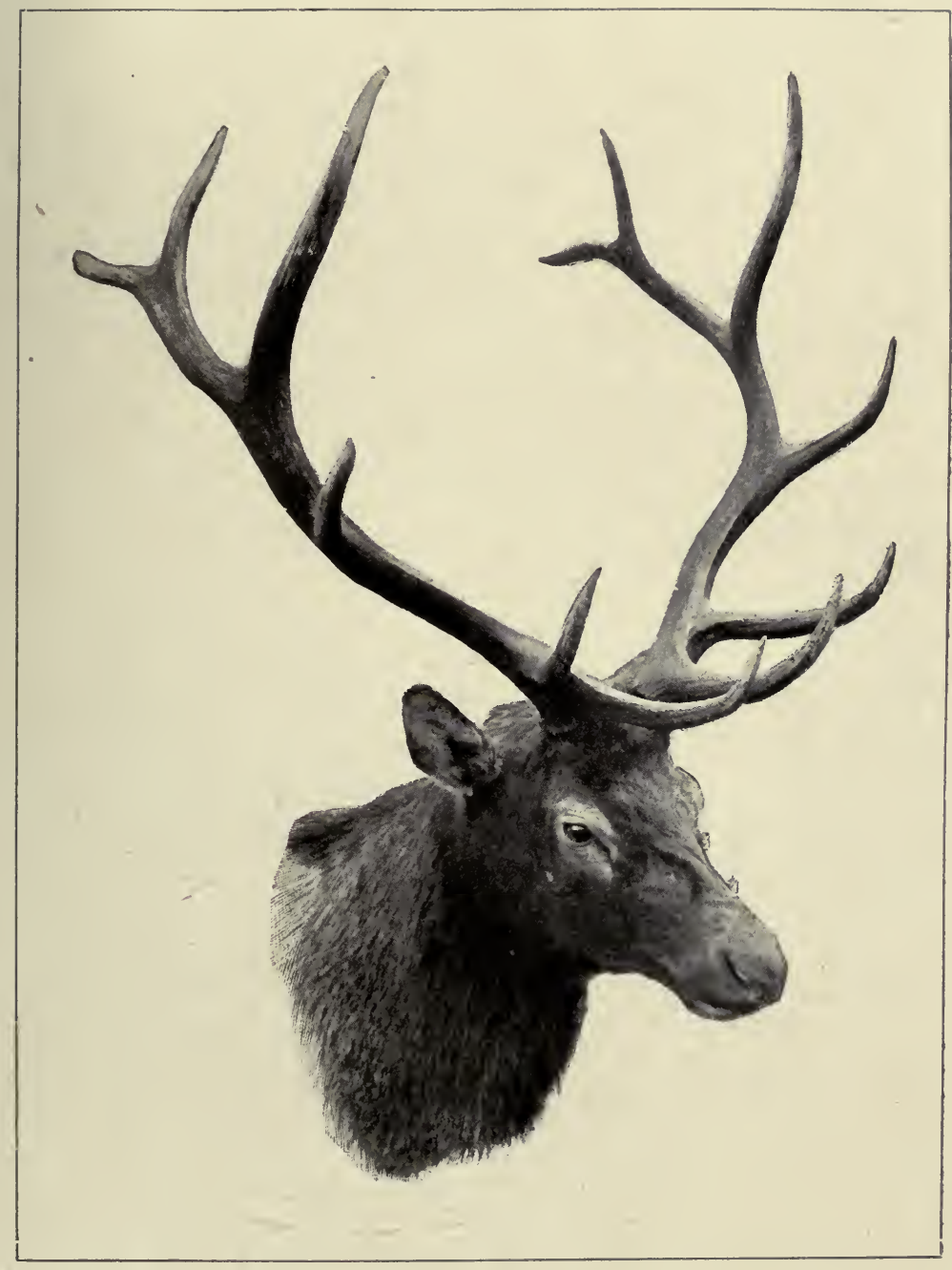

HEAD OF WAPITI

Shot in the Cabin Creek, November, 1897 

part of him to strike the snowy ground at the foot of the rock was his nose. Then the carcass slid down the steep slope amongst the pine-trees, and did not stop until it had reached the bed of the creek close to where we stood above the waterfall. Only the point of one tine of the right-hand antler was injured. The sheerness of the cliff down which he fell had probably saved his horns, for he touched nothing until his nose hit the steep snow slope at the foot of the bare rock. But the state of his nose, skull, and jawbone proved with what terrific violence he had struck the ground. The incisor teeth of the lower jaw and the whole of the end of the lower jaw were gone, the remainder of the jawbones being left separate from one another, whilst the skull was split from the nose right up to between the horns! The skin and flesh of the point of the jaw and nose were much split and smashed, but not nearly so much so as one would have expected from the state of the skull and jawbones.

This was by far the biggest-bodied and heaviest wapiti I shot, and he carried a very fair head, too, for nowadays. We found an easier way of getting down to the bed of the creek below the waterfall on the opposite side to that by which we had ascended, but it took us all our time to get the wapiti's head down.

As Davies wanted all the meat, we returned to the carcass of the wapiti the next day with a couple of pack horses, Davies and one of our men accompany- 
ing us. I took my small Austrian scale and some rope with me, and after having cut it up, we weighed the carcass carefully, and then lowered the various portions to below the falls with a rope.

The different sections weighed as follows:-

Skin of head and neck (uncleaned) . . $7 \frac{1}{2}$ kilos

Head and horns (without skin) . . . 20 "

Two hind-quarters together . . . . . 78 "

Two shoulders together . . . . . . 50 "

Barrel (with all the inside, including lungs, liver and heart, removed) . . . 45 "

Neck and part of brisket . . . . . 48 "

Skin

$33^{1} \mathrm{I} / 2$ kilos.

This works out to 725 lbs., $2 \frac{1}{2}$ ozs., or 5 I stone, I I lbs.; and as this weight was taken after the rutting season, this particular wapiti mignt have weighed 60 stone clean when in very high condition, or possibly about I Ioo lbs., live weight, for the gralloch I have found is about one quarter of an animal's live weight, both with antelopes and deer. Although this was probably considerably the heaviest of the few wapiti bulls I shot, yet when it is considered that there now only exists a poor remnant of the enormous herds of these splendid animals which once existed in Western America, and that those which still survive are now excluded from the rich pasturage of their former winter ranges by the encroachments of civilised man, one can hardly help believing that wapiti bulls weighing I 200 libs. as they stood must have been common 
some twenty years ago, whilst exceptional animals may have possibly very much exceeded this weight.

Not many years ago the American wapiti was indisputably the finest deer in the world both in size and weight of antlers, as well as in size and weight of body. He is undoubtedly still the heaviest deer in the world on the average, though the finest Hungarian and Caucasian red deer are possibly heavier than some full-grown wapiti of to-day, but I think it is doubtful whether the finest wapiti horns now obtainable in the Rocky Mountains are equal in weight to those of the finest red deer now living in Eastern Europe and Western Asia, or to the finest specimens of those of their nearer allies, the great deer of Central and Eastern Asia.

After having weighed the bull wapiti, Graham and I again went up Cabin Creek after wild sheep, and had a hard day's climbing, but saw nothing, nor any fresh tracks. We got back to Davies' about 5 P. M. and shortly afterwards one of our men saw an animal feeding on the side of the mountain right above the ranch. A look through the glasses showed that it was a wapiti bull. He had evidently been lying up in a patch of timber all day, and had just come out to feed. Of course he could see the ranch below him quite plainly, but as all the intervening ground was open, I suppose he thought himself safe from molestation from that direction. I went after him alone, and had first to walk about a mile down the river, in order 
to be able to climb to a level with him, out of view, and then approach him against the wind. I only just managed to get within shot of him, whilst there was still light enough to shoot, but at last I reached the edge of the piece of forest in which he had taken shelter during the day, and creeping to a rock on the open grass slope where he was busily feeding, killed him with a bullet through the heart at a distance of not more than eighty yards.

On the following day we brought the whole of the meat down to the ranch, and helped Davies to cut it up and dry it over fires for future use. I weighed this wapiti, and found him to be a very much lighter beast than the one I had shot two days previously, though he carried a very fair head of $\mathrm{I} 3$ points, with a good spread, and a length of 48 inches. His total weight clean was $236 \mathrm{kilos}$, which works out to 36 stone, I 2 lbs. He would, of course, have weighed a few stone more - probably upwards of 40 stonewhen in high condition, for when I shot him shortly after the rut, he was naturally much run down. Graham pronounced him to be a fair-sized bull of about eight years old, and it is on this pronouncement that I have hazarded the suggestion that the heaviest red deer stags of the Caucasus and Eastern Europe, which attain to a weight of 45 stone clean, are heavier than some full-grown wapiti bulls of to-day.

On November I, we packed all our traps on our waggon, and bidding good-bye to our kind friends at 
the ranch, moved about six miles down the valley to the mouth of Boulder Creek. For any one fond of trout-fishing, fresh bracing air, and glorious mountain scenery, I know of no pleasanter place than Davies' ranch. Any visitor there will meet with every assistance from Mr. and Mrs. Davies, who will be able to board and lodge them on reasonable terms, if necessary. Mr. Davies' address is Post Office, Ishawood, Wyoming, should anyone who reads this think of visiting him, and wish first to communicate with him.

Not finding any game in Boulder Creek, we moved farther down the main stream to a small ranch occupied by a Texan immigrant, locally known as "Timberline" Johnson. This man had just returned from a hunt on the North Fork, where he said he had shot a moose and a number of elk ${ }^{1}$ - bulls and cows whose skins he hoped to trade off during the winter to the Indians on the Crow Reservation.

A discussion having subsequently arisen concerning the game laws of the State of Wyoming, Mr. Johnson frankly confessed his ignorance on this subject. "He'd heard tell," he said, "that there were game laws, but they'd never troubled him much." One of our men then expressed the opinion that all game laws in the United States were unconstitutional, as the game belonged to the people. Naturally, with such ideas abroad, the game is rapidly decreasing in

1 Wapiti. 
this part of America, nor would it be possible to enforce the laws without the assistance of a very large staff of officials; for you can't prevent men from shooting wild animals in a wild country where otherwise no fresh meat is obtainable; and my sympathies are all with the settlers in this matter, as long as they are not wasteful. If the Yellowstone National Park could be somewhat enlarged, so as to allow of a more extended winter range for the deer and elk, all the great game of North America, with the exception of the bison (which apparently does not thrive there), could be preserved for all time; but outside the limits of the Park, game is bound gradually to become scarcer and scarcer in spite of laws for its preservation.

On November 3 the weather was cold and stormy, and in the afternoon fine snow commenced to fall. There are, or perhaps I ought rather to say, were, still a few white-tailed deer surviving in this part of the country, and I was very anxious to obtain the head of a fine buck of this species, but scarcely thought it likely that I would be able to do so, as these animals were said to be not only very scarce but extraordinarily cunning, having been educated up to the highest pitch of wariness to which it is possible for a naturally shy animal to attain by constant persecution at the hands of the ranchmen living along the river.

In Wyoming white-tailed deer live in the dense scrub which grows in the cottonwood bottoms, along 
the rivers which flow into the great plains from the eastern slopes of the Rocky Mountains, and never ascend the mountains themselves like the mule deer or the wapiti. Once very plentiful, they have now been almost exterminated in this State, as their haunts are being rapidly settled up. One settler, living on a ranch just below where we were camped, told me that it was several years since he had seen one killed, and said that the few that were left were so shy and wary that it was useless to hunt them. The snow, however, was in my favour, so I resolved to have a good try for one, Graham being as keen in the matter as I was myself. That afternoon we poked about quietly amongst the scrub along the river, but saw nothing. Fine snow kept constantly falling and continued to do so till late in the night, so that when we got up the next morning there was quite a foot of snow on the ground.

As soon as we had had something to eat, Graham and I sallied forth into the white frozen world which lay around our camp. It was Nov. 4, 1897, - the day on which the first railway train entered Buluwayo, - and we had scarcely walked half a mile from camp when we came on the track of a deer, which had passed in the night whilst the snow was still falling. It was impossible to tell exactly what it was, mule deer or white tail, buck or doe, as the hoof-prints had been nearly obliterated by the falling snow. However, Graham thought that as the tracks led 
through the scrub near the bank of the river, they had in all probability been made by a white-tailed deer. We had followed them for a couple of miles through several patches of thick scrub and underwood growing amongst groves of tall cottonwood trees, when they crossed the river, which was here some fifty yards wide and from two to three feet deep. Although the temperature must have been down to somewhere about zero, the stream was so swift that there was no ice over it, except just where the water touched the land. It was rather cold work crossing it, for not wanting to get our foot-gear and nether garments first wet and then frozen, we stripped below the waist, and went through with bare legs and feet, and had to go very slowly, as the bottom was covered with slippery pebbles, and the stream was very strong.

Arrived at the other side, we soon had our warm German socks and rubber overshoes on again, and by quick walking presently restored the circulation to our numbed feet. We had scarcely done so, however, when the inconsiderate animal we were following recrossed the river and gave us all our trouble and discomfort over again. After this it led us several miles farther through the thickly timbered bottoms bordering the course of the river. Its tracks, however, had been here made after the snow had ceased falling, and were very easy to follow. They were evidently those of a large buck deer, which Graham now felt sure was of the white-tailed species. The 
tracks wandered about very much; and though we followed them with the greatest caution, the wary animal we were after presently became aware of our presence, though our general direction was against the wind. I fancy he must have seen or heard us. At any rate we suddenly came upon the bed where he had been lying in a depression behind a fallen log, which he had left with a bound.

It was now eleven o'clock, and we had started the hunt at about eight, and it was not until after 4 P.M. that we finally brought it to a successful conclusion. Having failed to get on to our quarry by tracking, our plan now was to head him off. The patches of scrub from one to the other of which the deer ran, when disturbed, all lay in the valley of the river, but were often very extensive, making it very difficult to judge where he was most likely to pass. The new snow was greatly in our favour, as we never lost any time looking for the tracks. Graham always kept on the spoor, in order to keep him on the move, whilst I made circle after circle to try to head him and get a shot as he came past me. After having been once disturbed, he never went far before lying down again, but just dodged us, with the most extraordinary cunning. We had played this game of "hide and seek" for some hours, and it was already late in the afternoon when the chase led us back once more to the thick scrub on Johnson's ranch in which we had originally found the tracks of the deer. As I 
could now hear Webster chopping firewood at our camp, not far ahead, I did not think it likely that the wily old buck would have passed that point, so making a wide circuit, I took up a position in the middle of a thick wood, just on the bank of a small frozen stream. Graham I knew would presently come quietly on the deer's tracks, and once more put him up - though he always got off without becoming visible to his tracker. Would he at last come past me? and should I hit him bounding if he did? were the questions which I was putting to myself when suddenly I saw him.

$\mathrm{He}$ was coming through the scrubby rather open bush, straight towards me, in a series of great leaps, rising, I think, quite four feet from the ground at every bound. I stood absolutely still, thinking to fire at him just as he jumped the stream and passed me. However, he came so straight to me that had he held his course he must have jumped on to or over me. But when little more than the width of the stream separated us - when he was certainly not more than ten yards from me - he either saw or winded me, and without a moment's halt made a prodigious leap sideways. I fired at him when he was in the air, and I believe quite six feet above the ground. I had the sight fairly on him when I pulled the trigger, and he was so very near me that it would have required a very bad shot to have missed him, though to hit a white-tailed deer when 
running or rather bounding along at a distance of one hundred yards would, I should imagine, be no easy matter. For the moment my shot appeared to make no impression on the buck, as he continued his flight in a line parallel with the course of the little stream, in a series of bounds, which seemed to be taken with extraordinary ease and lightness. In a few moments he was out of sight.

I now walked quickly along on my side of the stream, looking for a place to cross it in order to see if there was any blood on the deer's tracks, and had not gone far when I suddenly saw him standing in the scrub, whisking his long fluffy tail from side to side. At the same instant he saw me, and with a bound crossed the stream to my side and passing through about fifty yards of scrub ran out into a piece of natural meadow land perhaps one hundred and fifty yards in breadth, which divided two patches of bush and across which there ran a rough wooden fence about four feet in height. Following in the direction the deer had taken, I was just in time to see him clear the fence, with such an easy, graceful bound that I began to think that I must have missed him, after all, or only given him a slight wound. I cut his tracks, however, as quickly as possible, and then saw at once from the way the blood was sprinkled over the snow that he had got the bullet right enough through the lungs, and would not be likely therefore to go much farther. 


\section{6

On reaching the fence and looking across the open ground beyond, I at once saw the wounded buck standing just on the edge of the farther wood. Then he moved slowly forwards, just within it. I now waited till Graham came up, when we at once made for the spot where I had last seen the deer. But before reaching it we saw the wounded beast lying down just within the edge of the wood. $\mathrm{He}$ was evidently dying, but fearing lest he might still have strength to make a dash into the river, which was quite close at hand, I killed him with a shot through the base of the neck. He proved to be a fine old buck, somewhat past his prime, Graham thought, but still with quite a nice head for this part of America, where white-tailed deer, I believe, never attained to the size and weight they reach in lower Canada and the eastern States.

After cleaning him, we dragged him to camp over the snow, and I then weighed him at once. He scaled twelve stone, seven pounds clean, which would have given him a live weight of about two hundred and thirty pounds. In Maine and Lower Canada I believe that white-tailed deer have been known to reach a live weight of three hundred and twenty pounds. I was intensely delighted to have brought to a successful conclusion my only hunt after a white-tailed deer, especially as I believe him to have been the only big buck of this species surviving in this part of Wyoming. 


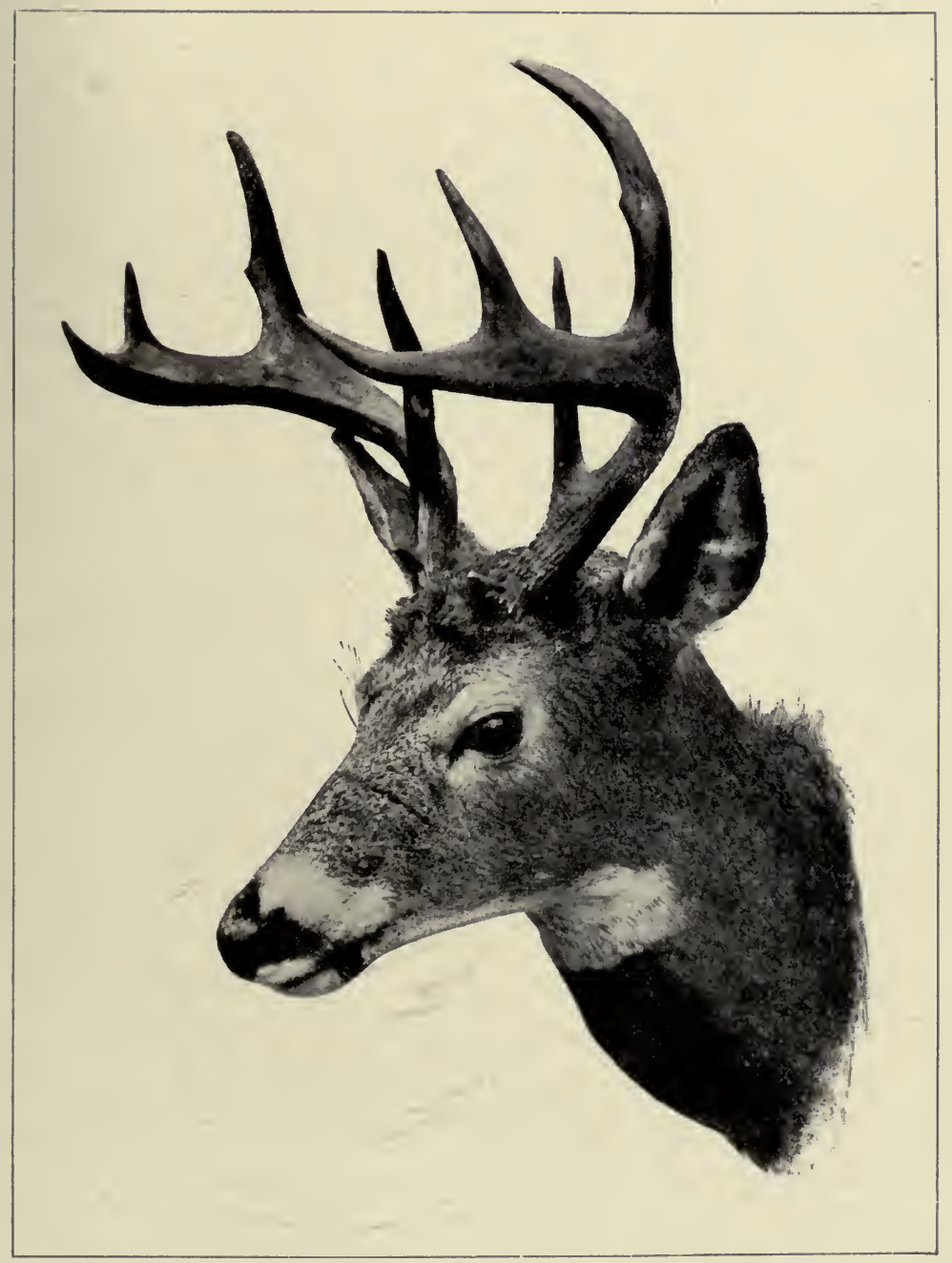

HEAD OF WHITE-TAILED DEER

Shot in the South Fork of Stinking Water, November 4, I897 

On November 5 we moved down to Rock Creek, where I had a great piece of luck the next day. Having climbed to a shoulder of the mountains at the head of the creek, I came suddenly upon four mule deer, which I had been tracking for some time. I might have shot any one of them, but as there was only a young buck with small horns amongst them, I let them alone. Soon afterwards we came on the tracks of a bull elk, and almost immediately I saw him about two hundred yards off just going into some thick timber, on the edge of which he had been lying. Being above him on the slope of the opposite hill, I could see him making his way amongst the trees in rather deep snow, and as soon as I was able to get a sight on him I fired and hit him. He only went a few yards and then stopped, and I then fired again, and distinctly heard the bullet tell. The wounded animal plunged forward for about ten yards and fell over, and when we got to him we found him quite dead. He was a fine big bull, and would have had a very pretty regular head of twelve points, had not the last tine on the right-hand horn got injured in some way whilst still in the velvet.

This was my last day's hunting in the Rocky Mountains during 1897 , and on the following morning we commenced our journey homewards.

Two days later, the weather, which had often looked threatening during the past week, became very disagreeable, and a bitterly cold wind compelled us to 
take refuge in the dry bed of Sage Creek, under the shelter of a high bank. Before the wind became violent, the surrounding plains had been covered with snow, but this was soon torn from the ground, and the whole air became filled with fine particles of snow mixed with sand and pebbles. In the course of the morning I came across two large packs of sage grouse (Centrocercus urophasianus) numbering quite a hundred together. They were all lying flat on the ground amongst the thinly growing sage brush, with their heads to the wind, and would not rise until I had almost ridden amongst them.

On the morning of November 9, the icy wind seemed to have increased in violence, if that were possible, and as we could not well travel during the storm I rode out to look for antelope. I came across a small band of seven or eight, but could do nothing with them, as they were fearfully wild and the wind made shooting almost impossible. I found, however, the skull of a bison bull in a very good state of preservation, the horns being on the cores, whilst a piece of skin with the hair on it still adhered to the nose. This skull I dragged back to camp with me with the aid of the rope which in Western America one usually carries on the horn of the saddle.

I was glad enough to get into comparative shelter again, for the cold wind had chilled me to the bone, whilst I had been half blinded by the sand and dust with which the air was filled. During the night the 
wind blew with terrific violence; and although we were camped in the shelter of a high bank, it was all we could do to keep the tent standing with the help of extra ropes, and by piling everything handy of any weight round the sides, both inside and out. The sand and small stones, of which the air was full, kept up a constant rattle against the canvas, and the finer particles beat through and gradually covered everything inside with a fine white powder. However, this last violent gust was the final effort of the storm, for after midnight the wind gradually dropped, and my wife and I were able to relax our watchfulness on the tent poles, and lie down and go to sleep.

The next day, although the wind was still blowing with disagreeable violence over the open plains of the Bighorn Basin, we resumed our journey, and after four days of dreary and uninteresting travelling reached a wayside ranch and post-office just at the head of a rocky gorge known as Prior's Gap. My wife and I had had a long and unsuccessful day after antelope, and did not get into the ranch till some time after dark. We were very kindly received by Mr. and Mrs. Bowler, who were old acquaintances of Graham's.

We were now in the State of Montana, and almost immediately after leaving Bowler's ranch on the morning of November I I, crossed the line of the Crow Indian reservation. In the course of the day we saw from twenty to thirty Crow Indians, amongst them a few women and children. With the memory of 
Catlin's portraits of the Crow Indians as they used to be in former days, I could not find these tamed and cooped-up Lords of the Prairie very interesting. They were all dressed more or less in European costume, and we passed two couples - man and woman - driving in buggies!

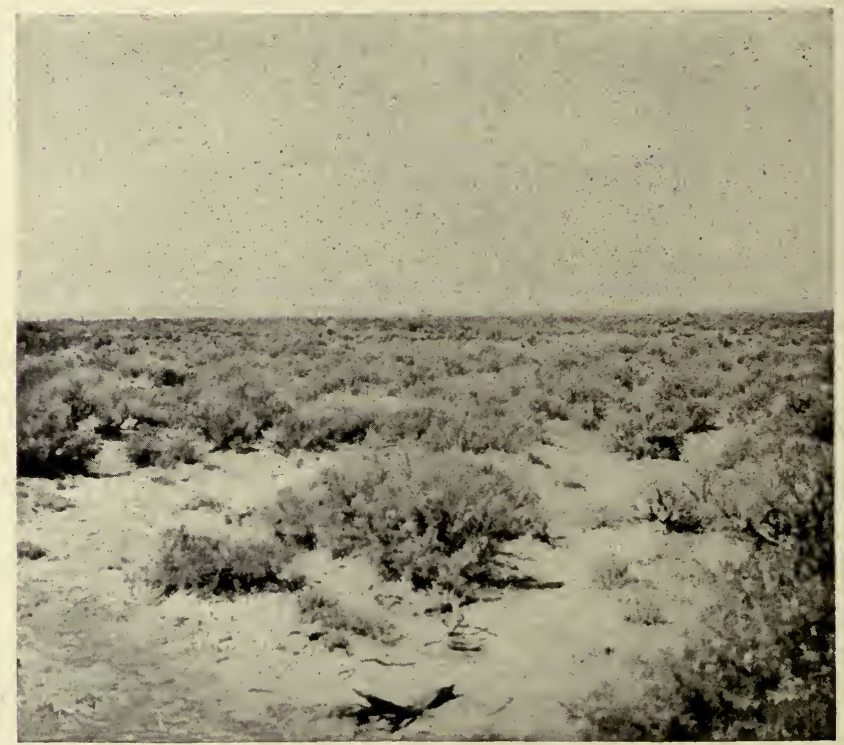

The Home of the Prong-horned Antelope, Sage-Bush Plain, BIGHORN BASIN

The costume affected by the male Indians I saw in the Crow Reservation consisted usually of a European coat, waistcoat, and trousers, plus a blanket worn like a kilt, fastened round the waist and hanging to the knees. They nearly all wore moccasins of untanned hide of their own make, but no socks. A 
handkerchief tied round the head, with a wide-awake hat and gloves, in cold weather completed their costume. In complexion none of the Indians I saw were of a rich enough colour to suggest the epithet "red." Some were dark and swarthy like Griquas or dark-coloured Hottentots, others of a pale sickly yellow exactly like the pale variety of the Hottentot. Most of those I saw were certainly under five feet nine, but though none were tall, none were very short. As a rule they were strongly built, though some of them appeared very fleshy. Graham, however, told me that twenty years ago a fat Indian was very rare, and thought they get fat now because they no longer lead a hard, wearing life, but are well fed by the United States Government without having to do any kind of work for their living.

In 1898 , on my second visit to the Rocky Mountains, I met an American gentleman who had lived out West for more than twenty-five years, and been in close contact with the Indians for the greater portion of that time, especially with the Crows, whose speech he had learnt, as well as the wonderful sign language, which, though now fast dying out, used once, it is said, to be understood by every Indian tribe in North America, from the Atlantic to the Pacific. He considers the Crow Indians to be a dying race, destined soon to disappear from the face of the earth, as the women bear but few children. They are, too, he averred, the reverse of a moral 
people, and far from being physically healthy, as there is much congenital disease amongst them.

The Sioux, however, a tribe which is made up of eight distinct clans, all of which are now living on reservations in the State of Montana, he looks upon as a splendid race of people physically, and does not think they are decreasing in numbers. Like the Zulus of South Africa, they endeavour to enforce chastity amongst their women by very strict laws. Should a woman be found guilty of adultery, her lips are cut off, often with such barbarous roughness that she loses a piece of her nose as well, during the operation. A woman so disfigured and dishonoured may be sent back to her father, and the ponies ${ }^{1}$ that had originally been paid for her reclaimed, or she may be retained by the aggrieved husband, no longer as a wife, but as his slave and the drudge of his other wives.

Mr. B. told me many stories illustrative of the stoical indifference with which North American Indians are capable of bearing physical pain, to which indeed they appear cheerfully to submit in cases where it seems unnecessary. He thought that their horrible cruelties to their enemies were possibly the outcome of their reverence for this Spartan virtue, which would tend to make the more chivalrous amongst them

1 Amongst the North American Horse Indians, wives are bought with horses, which animals are the chief medium of exchange in this part of the world. 
desire to give their enemies the opportunity of proving that they too were possessed of the one quality in human nature which the red man admires above all others, - the ability to bear physical pain without wincing. This theory, I must confess, appears to me untenable, and I am not surprised that during two hundred years of constant warfare between the white man and the red, the higher motives of the latter, when inflicting ingenious tortures upon the unfortunate pale faces who have from time to time fallen into his hands, have been invariably misunderstood and mercilessly revenged.

Mr. B. accompanied the first party of American troops which visited the scene of the massacre of General Custer and his force. Every corpse, he informed me, had been stripped naked and mutilated, with the exception of that of General Custer himself, which had been left untouched as a mark of respect for a man who was personally known to his foes as a man of superb personal courage. Should a fight take place, my friend told me, in the neighbourhood of an Indian village, as was the case in the Custer massacre, and should the attacking party get the worst of the fight, it is the women who take the chief part in the mutilation of their dead enemies. The sight of their own dead is said to work these emotional creatures into a state of such sublime fury that not only do they hack their enemies to pieces and pound their senseless heads to pulp with 
stone hammers, but often slash their own bodies mercilessly in their frenzy.

A Sioux chief whom Mr. B. had known well in former years, and whom he again met subsequently to the disaster to General Custer's force, in giving an account of the fight, in which he took part, said that the Indians suffered little loss in this encounter, as they attacked the whites in overwhelming numbers from the ambushes into which they had craftily led them, and killed them very quickly, General Custer and his brother, who fought their way to the top of the hill, where the monument now stands, being amongst the last to fall. As every corpse was buried exactly on the spot where it was found, a white tombstone now marking each dead man's resting-place, a survey of the battle-field gives one a very good idea as to what took place on that fatal day when Sitting Bull, for one last brief moment, stemmed the tide of the white man's conquest of that vast continent where once the red man reigned supreme. So complete was the ambush into which they were led that, as is well known, not a single member of General Custer's well-mounted force escaped. One man, however, the Sioux chief told Mr. B., got clean through the Indians, and, being exceptionally well mounted, would in all probability have escaped, when to their astonishment he turned and came galloping back amongst them. Thinking he had gone mad, he was not immediately killed, as 
a madman is considered to be sacred by the Indians. However, he was soon shot down by warriors too excited to give him the benefit of the doubt. If this story is true, this poor fellow must certainly either have lost his head and been for the moment really mad, or else, seeing that all his comrades had been killed, had determined to share their fate rather than to survive them.

It took us four days to get through the Indian reservation; and although Indians were usually conspicuous for their absence, there appeared to be no four-footed game left in their country. Sharp-tailed grouse (Pedioecetes phasianellus), however, were numerous along all the wooded creeks intersecting the prairie lands. These birds are most excellent for the table. I found them either very wild or very tame. They would either get up out of range, or else fly up into a tree, and let you pelt them with sticks or stones for several minutes before flying away. The quaint little prairie marmots were particularly numerous in the Indian reservation; and on November 15, which was a bright, sunshiny day, they were out in hundreds, scuttling over the snow from one burrow to another. Many of them let us pass within twenty yards of them without retiring into their earths. They seemed, however, to be in the wildest state of excitement all the time we were near them, and kept up a continuous cry of "cheep, cheep, cheep," twitching their little tails convulsively at each note. Their cry sounded to me like that of a bird 
rather than that of a mammal. I do not think water can be necessary to them, and expect they obtain the moisture they require from various roots.

I have nothing further to relate of our latter-day hunting trip to the Rocky Mountains. A few more days of monotonous travel, jog, jog, jogging wearily behind the loose horses, brought us at last once more to W. M.'s ranch at Bighorn, where we were most kindly received and hospitably entertained by Mr. and Mrs. Mackee, who were managing the ranch during our friend's absence in England.

It took us two days to pack our trophies and get everything ready for our journey home, and during this time I was able to see what hard work is necessary for successful ranching in Western America. A bell was rung at $5 \mathrm{~A}$. M. (two hours before daylight at this time of year, end of November), and all the "hands" - that is, those who labour on the ranch assembled to breakfast by lamplight at six. The cows were milked by lamplight also, and at seven, whilst the stars were still shining, work was commenced on the farm, which, with an hour's respite for dinner from twelve to one, was continued all day till dark, the cows again being milked by lamplight in the evening. In Western America, employers of labour and labourers (there known as hands) always take their meals together, so that we were usually a large party at table on M.'s ranch. One day, Mr. Mackee having gone off with all the hands to do 
some ditching work at a distance from the homestead, my wife and I found ourselves alone with Mrs. Mackee and her little four-year-old daughter at the midday meal. The little child looked round the room several times expectantly, but becoming at last convinced that no one else was coming to dinner, remarked in a clear nasal voice, "Why! we 're quite a small crowd to-day," a remark which tickled me immensely.

We finally bade adieu to Western America and all the kind friends we had made in that rich young land of a magnificent future, and entering the train at Sheridan, travelled by Chicago and Toronto to Ottawa, and taking ship at Portland in Maine - traffic on the St. Lawrence having been by that time suspended finally reached England in time to spend our Christmas at home. 
SECOND TRIP TO THE ROCKY MOUNTAINS

LTHOUGH amongst the few wapiti and mule deer I had shot in the autumn of 1897 , 1 two of the former and one of the latter had carried fairly good heads for nowadays, I had got nothing really large, nor had I seen a Bighorn ram at all; and it was in the hope of getting better heads of the two first-named animals, and perhaps securing a specimen of a Rocky Mountain sheep as well, that I determined to make a second trip to Western America in the following year.

As I could not afford to be absent from home for more than two months, I made arrangements with Graham - my guide and hunter of the previous year - to meet me at the little mining town of Red Lodge in Montana on a certain date. Having hunted the previous year during the months of September and October, I now wished to spend November in the mountains, as Graham thought that all the game would have been driven down on to their winter feeding-grounds by that time, and that I would therefore have a chance of seeing a good many wapiti bulls and picking a good head or two. 
Leaving Liverpool in the magnificent Cunard liner, the "Teutonic," on the afternoon of Oct. I6, I 898, I reached our trysting-place five thousand miles away in ten days' time, and should have got there a day earlier, had it not been that the unconscionable time I was detained in the custom-house at New York caused me to miss the night mail to Chicago. Things may be different now, but at the time of which I am speaking, the staff of officers in the New York custom-house was altogether inadequate to the work of examining and passing the baggage of the large number of passengers carried by such a steamship as the "Teutonic" in anything like a reasonable time, and although we got into dock before 6 P. M., it was past ten when I at last got to my hotel.

As the train drew up to the railway station just outside the little mining town of Red Lodge, I was rejoiced to see Graham standing on the platform awaiting me. He had left the camp outfit and most of the pack ponies at the Sulphur Springs near Cedar Mountain, two days' journey distant, and had come to the railway terminus with two riding horses and two pack animals to carry my baggage.

That night we slept at an hotel in Red Lodge, and made a start for the mountains on the following day, October 27 , in fine bright frosty weather. The first portion of our journey lay amongst the foot-hills of a spur of the Rocky Mountains, on which 
much snow seemed to have lately fallen. Presently, however, we left the mountains, and travelled hour after hour over monotonous plains sparsely covered with sage brush. Three days previously, Graham informed me, these plains had been covered with snow, but the wind had now swept them clean. As we had to lead the pack horses, we progressed but slowly; but it being bright moonlight we rode on till late at night, when reaching a small water-hole in the bed of a sand river, we relieved the horses of their burdens, and after having hobbled them rolled ourselves in our blankets and went to sleep. We got up again by moonlight at 4.30 A. M., intending to make an early start, but could not find the horses, which proved to have wandered off a long way, in spite of their having been hobbled. Finally we got off at 9 A. M. and reached camp at the Sulphur Springs at IO P. M. after a long day, although we had not covered a great distance, as the horses were tired and travelled very slowly.

About midday we came across a herd of pronghorned antelopes, with one good buck amongst them. Whilst they were looking at the horses, I slipped from my saddle and crawled to within one hundred and fifty yards of part of the herd, but the buck was more than one hundred yards farther away. I ought to have fired at him then, but thinking he would come nearer to me, I lay still. Suddenly, however, he sprang away and went off at a gallop, without 
giving me the chance of anything but a very long running shot. Some of the does and kids then came trotting past within one hundred yards of me; but for them I had no use.

Graham had engaged two most excellent fellows, both of them Englishmen, to accompany us on our trip and assist in all camp work. C. and T. were both of them well-connected and well-educated men, who came with me more for the fun and adventure of the outing than for any other consideration. I never wish for, nor could have, more pleasant and willing companions on a hunting trip, and there was never a cross word between any of our party during all the time we were together.

During the next four days we travelled steadily up the North Fork of the Stinking Water River; and having then reached a point which we judged to be about twelve miles to the east of the Yellowstone Park, we chose a good site for a camp, and resolved to have a look through the surrounding country for game, as we had already seen fresh tracks of both wapiti and mule deer. Soon after leaving the Sulphur Springs I shot and preserved for the British Museum a specimen of the white-tailed prairie marmot (Cynomys leucurus). These little animals are very nearly allied to the common prairie marmot (Cynomys ludovicianus). The Bighorn chain of mountains seems to divide the ranges of the two species in the State of Wyoming, for whilst all the prairie marmots I saw to the east of the Big- 
horn Mountains belonged to the common form, all those I came across in the Bighorn Basin to the west of the range were of the white-tailed variety.

On November 2, I had a hard day with Graham high up in the mountains after wild sheep. We saw a few

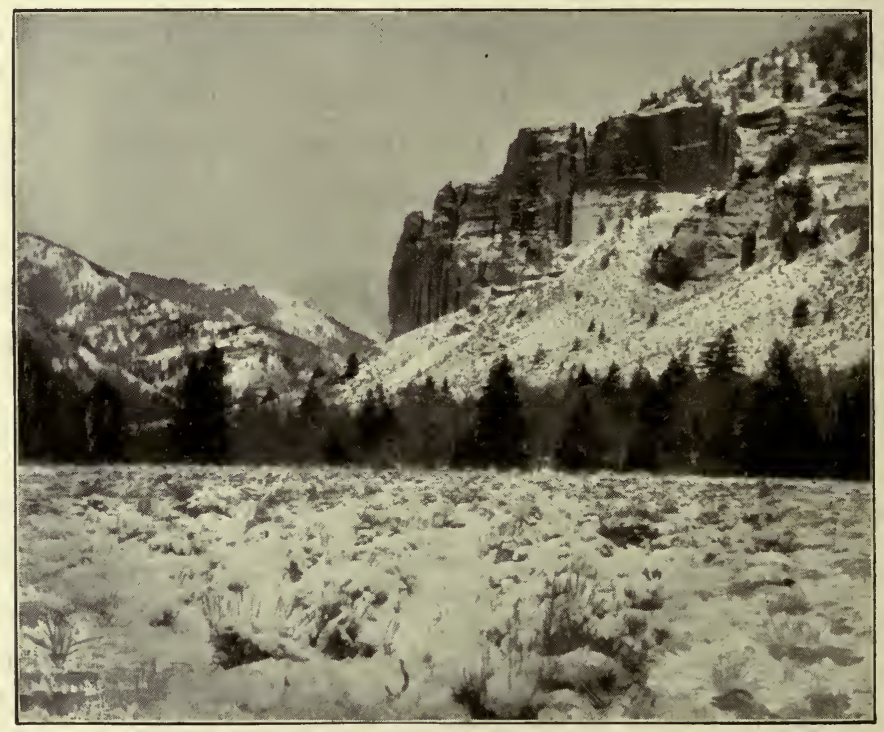

Valley of the North Fork of the Stinking Water River

tracks only a day or two old, but none of the animals themselves. In fact, the only living creature we saw was one little chipmunk (Tamias striatus). We scarcely saw a bird either. On the other hand, we obtained many beautiful views over some of the wildest ranges of the Rocky Mountains. A more magnificent-looking country for game it would be difficult to conceive, 
but though it still contains a few widely scattered bands of deer, wapiti, and wild sheep, these seem so scarce that it is impossible to banish the thought that the day may not be far distant when the whole of this wild country will become a dead wilderness uninhabited by man or beast. The weather had now become singularly mild for the time of year; and the snow, which had fallen heavily towards the end of October, was fast melting everywhere wherever the mountains were bare of forest.

On November 3, wet snow kept continually falling and melting on the ground, although we were probably some eight thousand feet above sea level. We moved our camp in the afternoon to opposite the mouth of a fine creek running into the main stream from the south. Whilst the tents were being pitched, I strolled along the valley of the main river by myself, and presently caught sight of an animal sitting like a cat on the trunk of a prostrate tree. At first I thought it was a puma, or mountain lion, as these animals are called in Western America, but on creeping a little nearer to it I saw that it was a lynx. It remained in blissful ignorance of my whereabouts until I killed it with a shot through the body behind the shoulders. On my way back to camp, I shot the head off a ruffed grouse, which soon afterwards formed the most interesting item in my supper. By the bye, the shot with which I decapitated this grouse was not of the sensational order, for the foolish bird, after flying up from the 
ground on to a branch of a cottonwood bush, sat there until I was within ten feet of it, when I thought the opportunity of getting a bite of fresh meat for supper was too good to be missed.

The next day was rather windy, but not at all cold. In the morning light snow kept falling. Graham and I hunted up the side-creek and about nine o'clock struck the fresh track of a buck mule deer. We followed it for several miles up and down hill, and at last got very near it; but the ground was unfavourable and the wind very shifty, and the deer at last either winded or heard us, and went off without giving a chance of a shot, though we just caught a glimpse of its white stern in a patch of thick timber. We saw nothing else nor the track of anything during the rest of the day.

On the following morning I went out alone, as Graham had to look after some of our horses that had strayed. I first rode some miles up the valley of the main river, and after fording the stream tied my horse to a tree and then proceeded on foot, following the course of a small tributary creek flowing from the south, through thickly timbered mountains. I soon came on the fresh tracks of four or five wapiti cows and calves; and although I did not actually follow them, for there was no bull with them, I kept crossing and recrossing their spoor, as they had been feeding all along the creek bottom during the preceding night. 


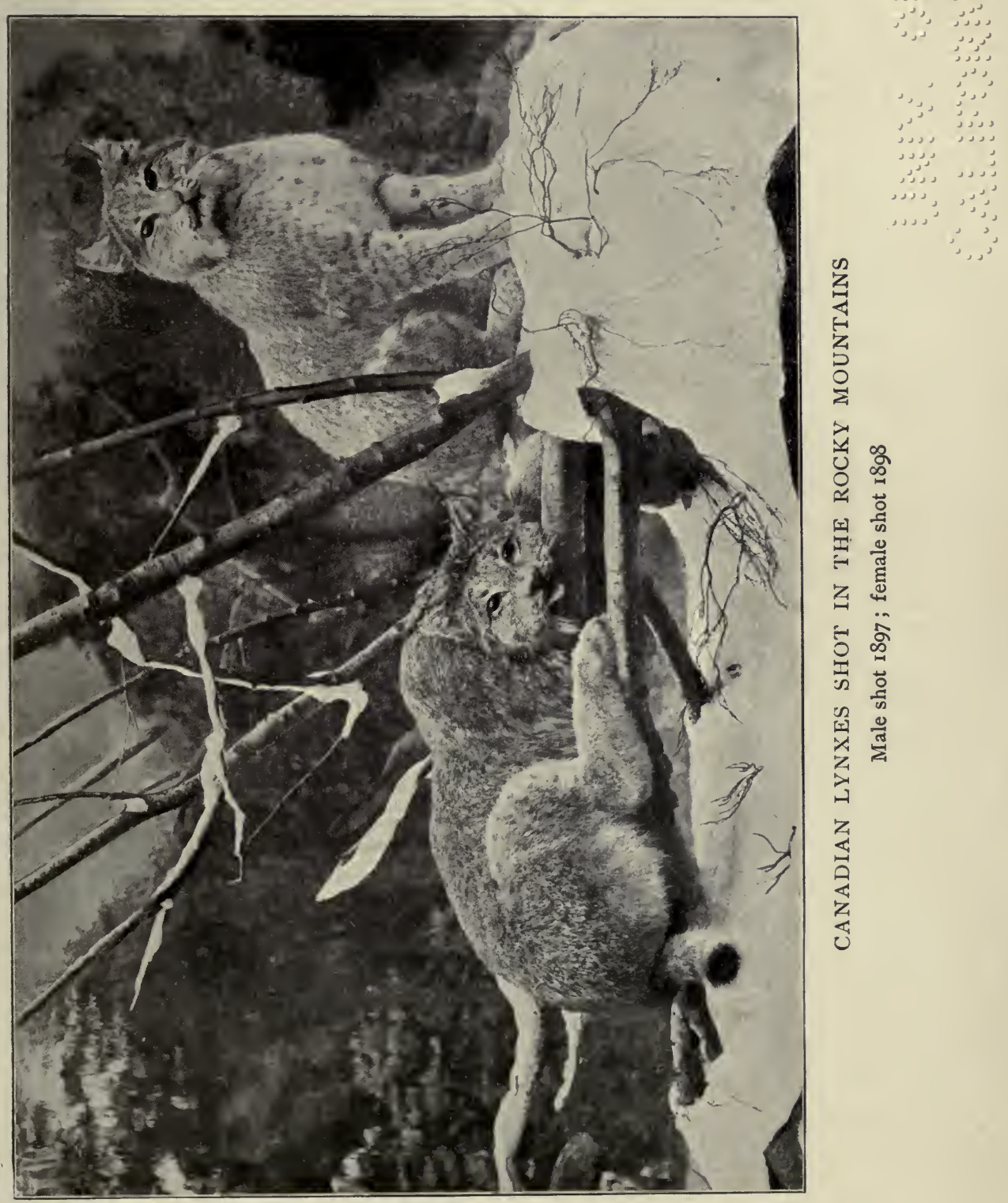


3
3
3 
About midday I left the valley and climbed the mountain-side to my right until I reached some very rocky and precipitous ground just above timber line, which had appeared to me from below to be likely looking ground for sheep. But seeing nothing and no tracks, and finding the frozen slopes, from which the snow had been blown away, dangerously slippery, I descended again into the pine forest beneath the shelter of which the snow still lay pretty deep. Presently I struck the fresh trail of a large buck mule deer and followed it to where the animal had been lying in the snow since it had left off feeding in the morning. It had, however, chosen its resting-place very cunningly on the thickly timbered slope of a deep ravine; and although I must have got very near it, I never saw it, though the tracks in the snow showed me how it had gone off at my approach in the succession of jumps invariably resorted to by mule deer when suddenly disturbed. After this I saw the tracks of a big bull wapiti which I think must have passed the previous night, but it was then too late to think of following them. Indeed, when I reached my horse, it was fast growing dusk, and was nearly dark when I got back to camp. On my way down the main creek I just caught a glimpse of a wapiti bull. I saw him dash out of a small cluster of pine-trees, gallop across a piece of open ground, and plunge into a cottonwood grove skirting the river. It was still light enough to allow me to 
see that he had horns, but whether he carried a fine head or was only a young bull, I cannot say. Had I only come home half an hour earlier, I might possibly have got a good chance at him.

The weather had now become wonderfully fine and warm for the time of year, and the mountains were rapidly losing their wintry appearance, for wind and sun had cleared the snow from every piece of open ground, even on the highest slopes of the mountains high above timber line. Beneath the pine forests, however, where neither sun nor wind had much effect, the ground was still everywhere covered with snow from a foot to two feet in depth. These conditions made hunting almost hopeless, for the wapiti and deer never came out of the forest except during the night, and in the forest itself were almost unapproachable, as the sharp frosts at nights froze the surface of the snow and formed a crust which would not bear a man's weight and always made a noise on being broken through. The game, too, which had commenced to come down towards their winter feedinggrounds during the October snow-storms, now all went back again to the higher forests near the verge of timber line, in fact, to their feeding-grounds of early autumn.

Another difficulty that I had not counted upon was getting about on the steep slopes of the mountains where there was no snow. By an oversight, I had left England without my shooting boots, and so 
wore, like Graham, "gum" boots over German socks, - the usual winter footgear in Western America. Now, the higher slopes of the Rocky Mountains to the east of the Yellowstone Park being very steep, and the ground every night frozen solid, it may be imagined that it was not easy to get about on them in gum boots; but the difficulty was very much increased by the heat of the sun during the day, which just formed a thin skin of mud over the frozen soil beneath, which on a steep slope was most treacherous and might easily have been fatal, as, once started on a slide downhill, nothing could have stopped one but a tree or a rock. I don't think that anything but the "Steigeisen," worn in winter by chamois hunters in the mountains of Europe, would enable one to get about easily in the ground I have described, when frozen but free from snow. It often took Graham and myself an incredible time to cross quite a small piece of open ground, and we had to do it on our knees very slowly and with the utmost caution.

Early on the morning of November 6, Graham and I got on to the fresh tracks of a bull wapiti, which in all probability was the same animal that I had just caught a glimpse of in the dusk of the preceding evening. We followed him for five hours along the course of a densely timbered ravine. He travelled along the hillsides, but crossed the stream at the bottom of the ravine several times, never once stopping to feed, however. At length he commenced 
to climb straight up the mountain-side above him, and Graham said that he was going to lie down; and, sure enough, after climbing very slowly and carefully on his tracks for four hundred or five hundred feet, we came to his first bed. As the forest was here so thick that any animal would have been invisible at a distance of fifty yards; and as moreover it was impossible to move noiselessly over the snow-covered ground, I don't think that anyone could have tracked up this wapiti and got within shot of him unseen or unheard even if he had remained lying on the resting-place he had first chosen. But this did not satisfy him, for he had only remained there a short time, and then after threading his way through the trees, back along the slope of the hill for about fifty yards parallel with the course he had followed lower down before he had commenced to climb, had made a second bed in the snow. With this position, too, he had become dissatisfied, for he had again got up and ascended one hundred feet or so higher up the mountain-side, before finally settling down for the day.

Here we disturbed him, for though we neither saw him nor heard him, his tracks in the snow showed us how he had first gone off at a trot on becoming aware of our neighbourhood, and then galloped obliquely down the mountain-side. Had we been very close behind this wapiti, and had he been travelling slowly and feeding, we might have overtaken him whilst he was still on the move, and perhaps got a 
shot at him, though the thickness of the timber, and the impossibility of walking noiselessly in the snow, would have been all in favour of the wary beast we were after; but nothing short of a miracle could have enabled us to have approached within shot of him after he had taken up his position for the day.

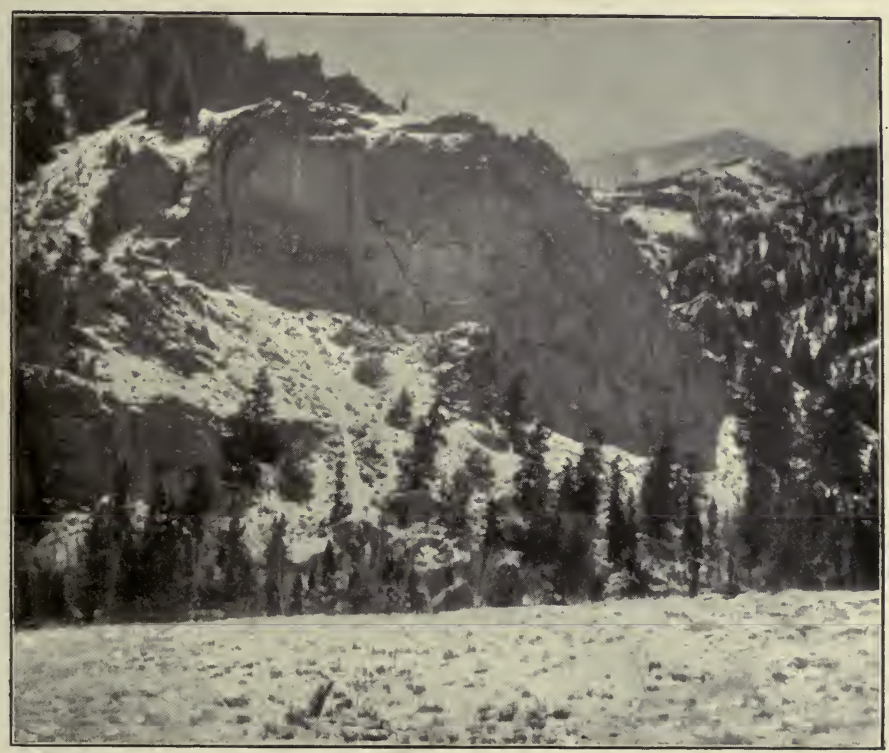

View near our Camp in the Rocky Mountains, November, I 898

We followed his tracks down to the stream at the bottom of the ravine, and then after a short rest started back for camp. Late in the afternoon, as we were approaching the main river, we came suddenly upon a broken transverse gully along the bottom of which grew a lot of thick cottonwood scrub. "There now!" 
said Graham, "that's just a likely place for a mule deer buck!" The words were scarcely out of his mouth when one of these animals - which had probably neither seen nor winded us, but only heard Graham's voice - rose from the edge of the scrub, and, trotting a few paces forwards, stood still listening. He was not fifty yards from us, but I could not shoot, as with the exception of his head and horns, the whole of his body was hidden by the stem of a large cottonwood tree.

I stood quite still, holding my rifle at full cock, ready to fire the instant he came out from behind the tree. But when he presently moved forward at a slow walk, he at first kept the tree between us. Then suddenly he turned and went away obliquely, in a series of jumps, as is the custom of these deer. As he had to go some twenty yards over open ground, and was not more than seventy yards away from me when I fired, he gave me, of course, as easy a shot as one could expect to get at a jumping deer; but his pace was so uneven that I fully expected to miss him. He did not flinch at the shot, but went jumping along until he disappeared in the cottonwood scrub; and though I had thought my sight was on him when I pulled the trigger, I never heard the bullet thud and was fully prepared to find I had missed. Graham, however, said the buck was hit, and on reaching his track a very heavy blood spoor showed that such was the case, and we found him lying dead within fifty yards 
of where he had been struck. The bullet had entered just behind his shoulder, and ranging forwards had come out on the other side near the base of the neck, tearing a large hole through the heart and lungs on its passage.

This was a fine buck mule deer with a pretty head of nine points. He was in splendid condition, the fat on his rump and over his loins being more than an inch thick. The meat was first rate, without the least suspicion of the rank flavour always perceptible in the meat of a buck mule deer as soon as it has commenced to rut. From subsequent observations I am quite sure that in this particular year, I898, and in the particular part of the country in which I was then hunting - the mountains to the east of the Yellowstone Park - the mule deer bucks did not commence to rut before the middle of November. We carried the head, inside fat, and some of the meat of the slain deer back to camp with us, after having buried the remainder of the carcass under the snow.

\section{II}

During the next few days we found the fresh tracks of wapiti bulls almost daily, and followed them for many hours, but always without result, for though we must always have got very near them, they invariably heard or winded us in the thick timber without our catching sight of them, and I began to despair 
of ever getting a shot at a wapiti at all unless the weather changed. On the evening of November Io, I wrote in my journal, "No sign of snow; no hope of getting game;" and these two sentences seemed to sum up the position. What we wanted was a

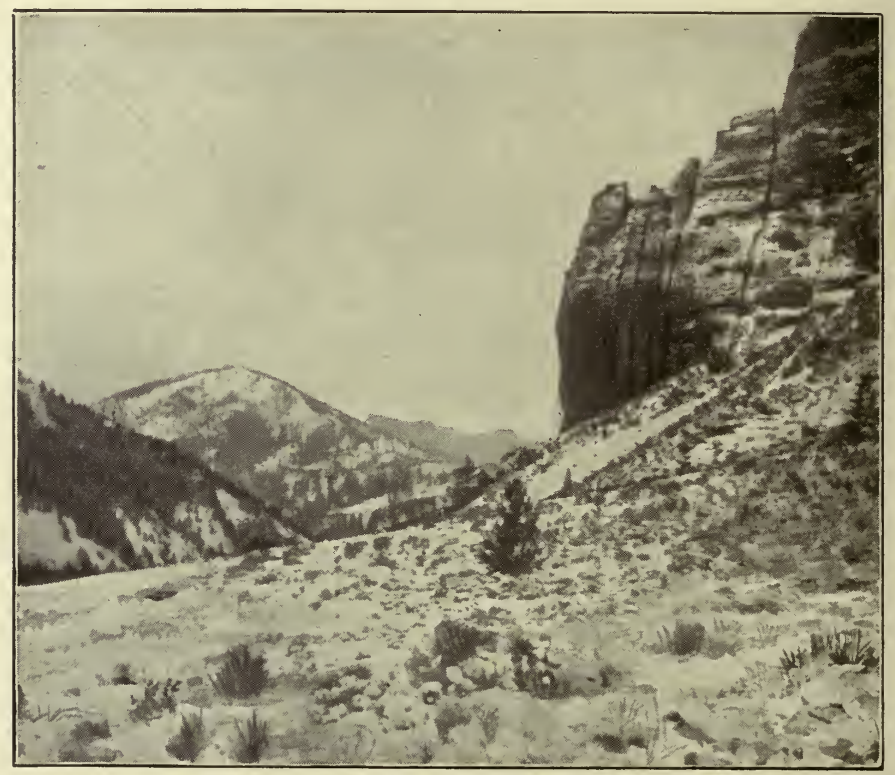

Scene near Camp in the Rocky Mountains, November, i 898

three days' snow-storm, which would have driven the wapiti down from the high forests and brought them on to more open ground in search of food, for the wind soon blows the snow from the treeless slopes of the mountains. The old snow which still lay to the depth of a foot or more over all the forest-covered ground was of no use to us, - except that it made 
tracking very easy, - for it was very noisy to walk in, and not deep enough to prevent wapiti and deer from scraping it away and feeding on the grass beneath; and as long as they could do this they remained, at any rate, by day, always in the thick forests, where they knew no doubt that they were practically unapproachable.

The weather remained extraordinarily fine for the time of year, and in the middle of the day the sun was sometimes quite powerful, though the nights were usually cold. On the night of November 7, my thermometer registered $32^{\circ}$ of frost, and until the I6th went down to the neighbourhood of zero every night. Then we had three singularly warm nights, and I find a note in my journal on November i9 to the effect that "last night the thermometer only just reached freezing-point, and had risen above it by daylight," a somewhat remarkable record, I should think, for the latter half of November in the Rocky Mountains, at an altitude of eight thousand or nine thousand feet above sea level. The next night, however, we had $27^{\circ}$ of frost.

As regards seeing a fair number of wapiti and getting the chance of picking a couple of bulls with good heads, my trip was a failure; for though there were doubtless a few good bulls about, and I was often very near them, I never saw a really fine one, and only twice saw wapiti of any kind at all.

The first occasion was on November I I. Graham 
and I had left camp just as day was breaking and had made our way for a couple of miles up the valley of the main river, when we made out some animals moving along near the crest of a ridge about one thousand feet above us. It was by this time broad daylight, and a look through the glasses showed us that the game we had seen was a band of wapiti hinds. The ground on which they were when we first saw them was a steep grass slope free from trees, but we knew that they were quite close to a dense forest which covered the whole face of the mountain on the farther side of the ridge.

As the hinds we had seen soon disappeared from view, and we thought it very likely that there might be a bull somewhere near them, we at once prepared to follow them. It was a stiff climb to the top of the ridge, as the steep frozen grass slopes were very slippery and difficult to negotiate without.spiked shoes. Along the top of the ridge we found the snow still lying to the depth of a foot, as it had been sheltered from the sun and wind by the dense pine forest, which clothed the farther slope right up to the top. We found that the herd of wapiti we had seen from below had followed the ridge upwards; but there were some tracks going the other way and Graham was examining these, when I, who had walked a few paces on ahead, suddenly saw the head and ears of a hind just appearing above a curve in the ground above me. I ducked down in- 
stantly and then crawled forwards on my hands and knees till I had reached the prostrate trunk of a fallen tree. Then raising myself I peered over it and saw a dozen or fifteen hinds and calves all lying close together on the top of the ridge and on the very edge of the thick timber, into which they could instantly have dashed had anything approached them directly from below, which of course they would have been able to see on the open ground, whilst the wind would have warned them of the approach of anything through the forest behind them.

As we had made a considerable détour and reached the top of the ridge at a point some distance below the position these cunning beasts had taken up for the day, they had neither seen nor scented us. At first I could not see a bull with them, but I soon made out one lying a little below the rest of the herd and half hidden by some small spruce-trees. I could not see his head at all, but his size and the very light colour of his body made me sure of his sex. I was about one hundred and fifty yards distant from the wapiti; and as they seemed absolutely unconscious of danger, I crouched down again behind the log, and turning round, beckoned to Graham, who was about one hundred yards away on the ridge below me. He saw that I had seen the game we were in search of and came up to me very cautiously; but nevertheless, when we raised our heads together for another look, they were all standing up, 
and were evidently suspicious. Their sharp ears must have heard something, for they could neither have seen nor winded us.

The bull was standing below the others facing down the hill, with his head and horns almost entirely hidden behind a small spruce fir. Somehow I did n't think he was a big bull, but I could not tell and dared not wait, for he was the only bull in sight, and a single step forwards would have placed him out of danger. So I fired for his shoulder, - he was standing nearly broadside on, - and at the shot he dropped in his tracks, rolled over clear of the small trees which had partially covered him, and then went sliding down the very steep snow slope, through the forest below him, cannoning from tree to tree until the battered carcass was finally brought up between the stems of two trees growing close together.

At the shot the hinds and calves first ran a short distance up the slope, then stood for a few moments looking about them, evidently uncertain as to the nature and whereabouts of the danger that threatened them, and finally plunged into the forest below them. The bull I had shot was, alas! of no value to me, for not only was his head - an eight-pointer - too small to be worth keeping, but his one horn had been broken off just above the second tine by coming into violent contact with a tree as he slid down the steep snow slope. Nor was this all; for we found on following the carcass to its final resting-place that there 
had been two big bulls near the herd, which we had never seen. With the superior cunning of old bull wapiti, they had, I suppose, kept ahead of the cows, and left the open ground just before daylight.

Following up their tracks, we found that they had been lying down in the thick timber below the ridge, about two hundred yards away from the hinds when I fired at the young bull. However, even had there been no hinds, and we had only followed up the tracks of the two old bulls, I don't think that I should ever have got a shot at them. They would almost certainly have heard us before we saw them, and trotted quietly away in the thick forest. Thinking that a single shot with a.303-bore rifle could not have disturbed them very much, we spent several hours trying to circumvent them. Noting the line which they appeared to be taking, I made wide circles to try to get in front of them, and then took up a position on the side of one of the ravines which scored the mountain-side, and gave me a view over a certain amount of open ground. Graham would give me an hour's start, and then take up the spoor, hoping to disturb the old bulls in thick timber, and drive them forwards across the open ravine I was watching. However, I never saw them, and we came to the conclusion that the forests in the Rocky Mountains are too large and thick to render the success of such a stratagem very likely. In the afternoon we returned to the carcass of the young bull, which we gralloched in order to 
remove the inside fat, and then covered with snow, as Graham wanted to use it later on for a bear bait.

On the second occasion of my very limited success with wapiti on this trip, I had the luck to come up with some of these animals whilst they were still on the move, and for once managed to get within shot of them, as although the forest in which we found them was pretty thick, the noise they themselves were making probably drowned the sound of our footsteps in the snow. This small herd of wapiti must have passed close to our camp in the early dawn and we got on their tracks before they had gone very far. We followed them up the same ravine in which I had shot the first mule deer, eight days earlier, and overtook them before midday. Just before we got up to them, they led us through a very thick patch of small larch-trees, and I had just come to the conclusion that they would be sure to hear us approaching before we saw them, when we heard a sound in the forest above us as of a horn being struck against a tree. "That's them," said Graham, and with beating hearts we commenced to climb towards the sound as noiselessly as possible, I going in front with my rifle at the ready.

I had just got out of the thick patch of larchtrees when I saw two wapiti bulls amongst the big fir-trees on the hillside above me. They had evidently heard something, at least I think so, as they were walking quickly one behind the other, as if 


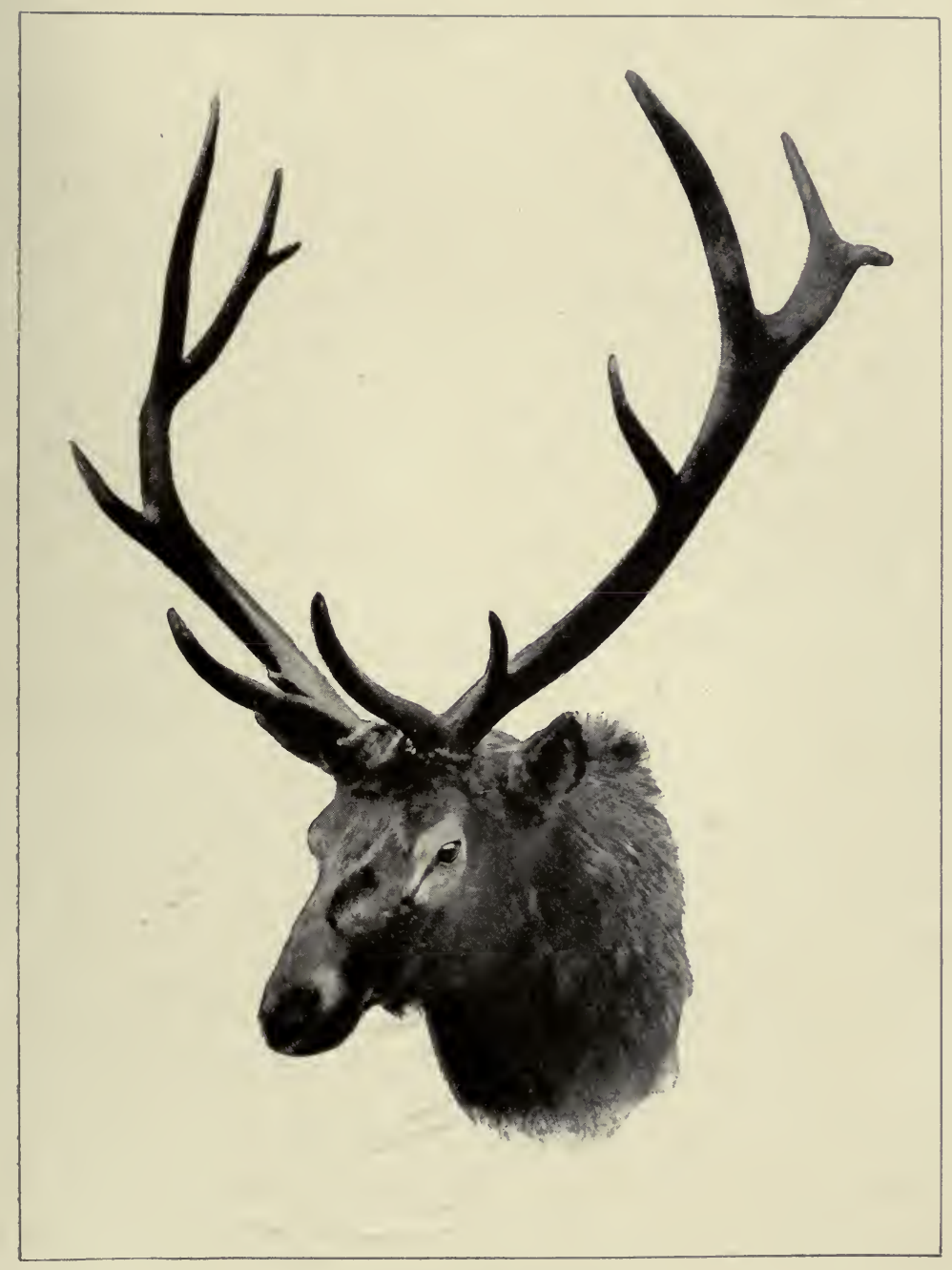

HEAI ()F WAPITI

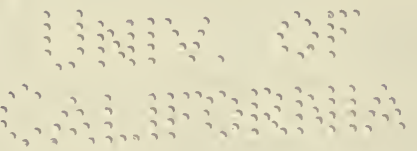



slightly alarmed. They were not more than seventy or eighty yards away from me, amongst big timber, the trunks of the trees not being very close together. However, it was not very easy to get a clear shot, and I could not immediately fire; and when I did so the two bulls were nearing the edge of a small gully. I fired at the leading animal, and felt sure I had hit him, and got another cartridge into my singlebarrelled rifle just as his companion pushed past him on the very edge of the afore-mentioned gully. I now tried to get a shot at the latter, but he was completely shielded by the one first hit, into which I therefore put a second bullet. Both animals then disappeared into the gully; and though I could not be certain, it almost appeared to me that the wounded one fell into it. The unwounded one, however, appeared again almost immediately, a short distance higher up the gully on the same side by which he had entered it, and commenced to climb diagonally up the forest-covered slope above him. When about one hundred yards from me, he stopped and turned half round, probably to look for his companion.

As he stood, I got a clear view of him through the trees, and fired at him. This bullet struck him in the chest just in front of the left shoulder and must have passed through his heart, or cut some of the big arteries just above it, as he collapsed almost immediately, and came sliding, an inert mass, down the steep snow slope, until at last brought up against 
the stem of a big tree. I was making my way towards where he lay, when Graham, who was behind me, whistled softly, and on my turning round pointed up the mountain-side above us. At first I saw nothing, but soon caught sight of a wapiti bull threading his way through the forest. The timber on this part of the mountain was large and more open than usual, so that although the wapiti was often entirely hidden from view, portions of him frequently came in sight between the trees. He was climbing slowly upwards, constantly halting, and when I first saw him, must have been nearly two hundred yards away. No other thought entered my head than that this was the bull at which I had fired my first two shots, and which I was sure I had wounded. The deliberation of his movements I attributed to the weakness caused by loss of blood. I thought that he had probably climbed uphill in the shelter of the gully after my second shot, and had only just emerged from it again when Graham caught sight of him. Fully believing him to be wounded, and seeing how slowly he was moving, I tried to get nearer to him. But the most frantic exertions to climb quickly up the slippery snow slope in my "gum" boots only resulted in putting me thoroughly out of breath, as I kept continually slipping and falling flat on my face, and rather lost than gained ground on the object of my pursuit.

At last I lay where I fell, flat on my stomach, and 
with my feet against a tree fired two shots at the wapiti now far above me. He must have been quite two hundred yards away, and both times I could only see his hind-quarters. I was lying in a very good position to take a steady shot, but I was panting so from my recent exertions that I hardly expected to hit my mark. After my second shot I lost sight of this wapiti altogether, as he got amongst thicker timber. Graham and I then went down to the bull I had killed with my third shot. He was a disappointing animal; for although he was a twelve-pointer, his horns were weak and stunted, and I felt very sorry I had killed him. That's the worst of shooting in thick forest. It is impossible, from the momentary glimpse one gets of a moving animal, to tell whether his horns are worth having or not. This poor beast was of no use to me, though I took his head skin, and Graham afterwards used his carcass for a bear bait.

On expressing my surprise that the bull at which I had fired my first two shots should have managed to get so far up the mountain as he was when we last saw him, Graham said he thought that I had fired at three different animals, the first of which had never come out of the gully again after being wounded. This we soon found to be the case, for on going to the edge of the little gully where the bull I had first fired at had stood just before disappearing, we found him lying dead against a tree 
a short distance below us, and I was rejoiced to see that he carried quite a nice head, though not better than the best head I had got the preceding year. Both my bullets had struck him, and either would have proved mortal; in fact, I fancy he was on the point of succumbing to the first, which had broken his shoulder and must have passed very near his heart, when the second struck him a few inches farther back, and caused him to fall dead into the gully below him.

We now climbed the hillside - a most difficult and tedious operation in "gum" boots - to where the third wapiti had been when I fired at him, and soon found blood on his tracks. We followed him for about an hour in some very steep rocky ground, and then, as it was evident that he had not received a mortal hurt, but was only bleeding from fleshwounds in the hind-quarters, we thought it advisable to give him time to lie down, - which Graham said that he would be likely to do before going very far, if he did not think he was being pursued, - rather than run the risk of again alarming him, whilst he was still very much on the alert, in which case he might very likely give no chance of a shot, and would be sure to travel many miles before halting. We therefore went down and cut off the head of the larger bull, removed the head skin of the smaller one, and opened both carcasses to get the inside fat. It may be thought strange that a wapiti bull of any size should 
have any fat about it in November, - that is, shortly after the rutting season. All I can say is, that two of the four wapiti bulls I killed this season were fine large animals, probably seven or eight years of age, and that we got four or five pounds of inside fat out of each of them, neither of the two younger bulls being in quite such good condition. By the time we had finished our work with the dead bulls, it was already getting late, so I decided not to again follow up the wounded bull that day, but to get back to camp as quickly as possible, in order to clean and prepare the head skins before they froze, as they would be sure to do during the coming night.

On the following morning we made an early start after the wounded wapiti, and found and killed him before midday. He had not gone very far, but had crossed some very steep, open pieces of ground, which, being frozen, were very treacherous, and almost impassable in "gum" boots. These places we had to cross on hands and knees, and this took time. We finally found the wounded beast lying down in thick forest, and came on him before he was aware of our approach. I fired at him as he lay, and killed him with a shot through the lungs. He proved to be a fine large animal, with a pretty head of twelve points. On examining him, we found that both my bullets had struck him the previous day, though the one had only inflicted a slight flesh-wound through the upper part of the left hind-quarter, which would not alone 
have caused him anything but a little temporary inconvenience. The other shot had gone right through his left thigh and made a large wound - as the bullet had then expanded - on the inside of the other limb. Graham, however, said he thought that if he had been left alone, he would have recovered from this wound too; and I am inclined to agree with him, as fleshwounds, however severe, seldom kill either wild animals or healthy men.

\section{III}

Although in the short time at my disposal I saw no wild sheep, and but few wapiti, I was somewhat more fortunate with mule deer, as I killed four fine bucks of this handsome species, - the only four I fired at, two of which carried really good heads, strong in the beain and widespread, whilst the other two were quite good enough to make handsome trophies.

The death of the first of these deer I have already described. The second I shot two days later on November 8. I had gone out by myself - Graham having again had to look for strayed horses - and after crossing the river had climbed a thickly timbered shoulder of the mountain just opposite our camp. On the top of this shoulder I found an open piece of ground, which in summer would probably have been as gay with flowers as an Alpine meadow, but now was a white expanse of snow a foot or so in 


\section{SPORT AND TRAVEL}

depth, the ground being level and sheltered from the wind by the surrounding forest. This open piece of snow-covered ground had evidently formed a playground for quite a herd of mule deer during the preceding night. They had been jumping and frisking about for a long time, and had crossed and recrossed the open ground in all directions. But they had never lain down or scratched the snow away to feed, and had finally gone off down the mountainside into the thick forest below. The tracks on this playground were all small, obviously those of does and fawns, and I could not find the spoor of a big buck amongst them. But I thought that there would in all probability be one or more of the latter in the neighbourhood, and, sure enough, soon struck the fresh track of a fine stag, in the rather straggling forest just above the open ground. I felt sure the animal itself was somewhere near, and so followed it up very cautiously, keeping my eyes ranging well forwards, and trying to make no noise, or at least as little as possible.

In this way I had advanced very slowly for a short distance, when suddenly I saw the head and horns of a beautiful mule deer buck raised above a little scrubby fir bush. I was amongst some trees about a hundred yards away, and I don't think he had seen me, but had probably only heard my footsteps in the snow, for I afterwards found that when I saw him he was standing on the bed from which he had doubt- 
less just risen. As I have said, I could only see his head and horns and a bit of his neck, all the rest of him being hidden from view by the fir scrub behind which he was standing. But he was looking straight towards me, and was, I felt sure, alarmed, and might bound off at any moment; so raising my rifle and aiming straight below the portion of his neck I could see, for where I thought his chest ought to be, I fired. I saw that he did not fall to the shot, but jumped away, becoming immediately invisible behind the fir scrub, yet I went towards where he had been standing, feeling confident that he was hit, for I thought I had heard the thud of the bullet.

I soon reached the spot where he had stood when I fired, and looking forwards could see the traces of the first half-dozen of the great bounds he had taken down the hillside. But as far as I could see, the pure white snow was unsullied by the least trace of blood. After all, I thought, I must have made a bad shot and missed a good chance; and I wished that I had risked disturbing the buck by taking a step forwards after I saw him, and steadying my rifle against the stem of the great fir-tree just in front of me. Still I had thought I was steady enough when I fired, and moreover I believed I had heard the thud of my bullet, but yet there was no blood on the snow; at least not immediately, nor within twenty yards of where the buck had commenced its headlong flight. Then indeed there was blood enough, and a crimson 
trail led me quickly to where the victim of my smallbore rifle lay dead. My bullet had struck him just above the breast-bone at the base of the throat, and passed just above the heart, no doubt cutting some of the large arteries. The blood had not come from the bullet-wound, and I suppose that at first the hæmorrhage had been internal, but after a few bounds the dying beast had commenced to throw great quantities of blood from his mouth, and soon fell dead.

He was a beautiful animal in full winter coat of soft grey, with the dark patch on the forehead almost black, and the snow-white hair on the back of the rump extending to above the root of the tail. $\mathrm{He}$ carried, too, a pretty even head, somewhat larger than that of the first mule deer stag I had shot. Like the latter, he was in splendid condition, the fat over the loins being more than an inch in thickness. After cutting off his head with a good long neck, I cleaned him, and took out all the inside fat, which I tied together and made into one bundle with the head to carry home. Then I left the carcass belly downwards on the snow, to be brought into camp later, and made my way down the mountain.

When I first visited the Rocky Mountains in I897, the casual way in which our hunters were accustomed to leave good meat lying about in the mountains to be brought into camp when convenient, surprised me, I must say, very considerably; for in South Africa, if you leave a dead animal of any kind lying uncovered 
on the ground for two hours during the daytime, you will find very little of him left by the ubiquitous vultures but skin and bones; whilst at nights in any part of the country where there is game, a carcass will seldom escape very long from the visits of lions

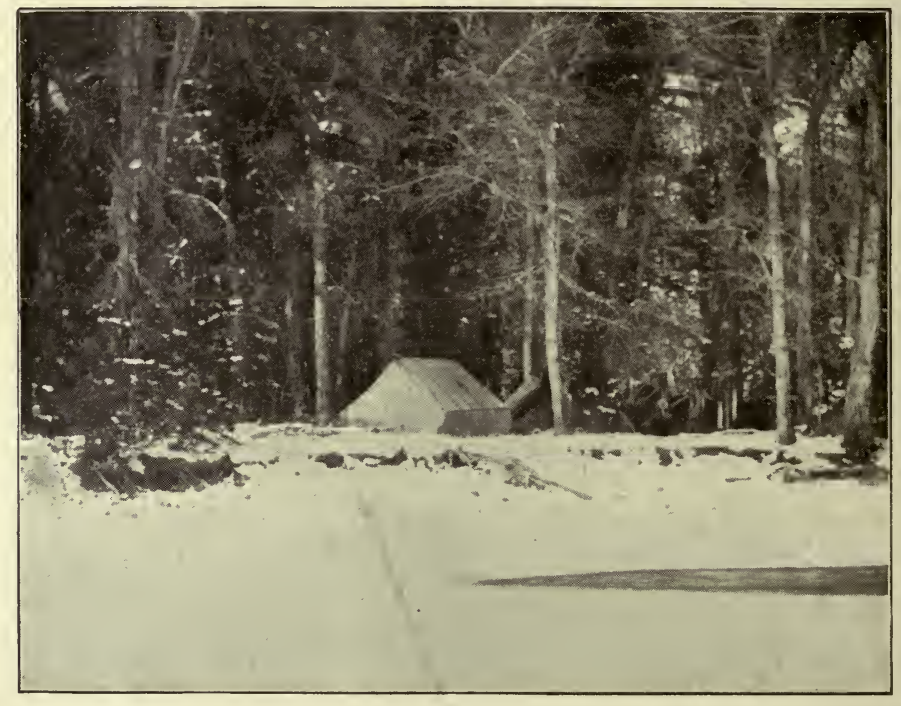

Tent pitched in the Shelter of the Forest. Frozen River in THE FOREGROUND

hyenas, or jackals. But in the solitudes of the Rocky Mountains - at least in that part of them where I was hunting - there are no vultures, wolves, or coyotes, but few bears or wolverines, and not even many foxes, lynxes, or martens. In fact, so scarce are all beasts and birds of prey that although we set traps round all the carcasses of the wapiti I killed, and left three of the 
mule deer lying out in the snow for several days, we caught nothing in the traps but two Clark's Crows, and did not have any of the mule deer interfered with. Not a single bear, wolverine, lynx, fox, or marten ever came near any of the carcasses. As the insides had been removed from all of them, and they all lay high up in snow-covered ground, there was certainly no smell about them, but the telltale snow showed clearly enough that with the exception of "snow-shoe rabbits," there were scarcely any other animals whatsoever. in the mountains to the east of the Yellowstone Park but wapiti and mule deer, and there were none too many of them.

The "snow-shoe rabbit" of the hunters and prospectors of the Rocky Mountains is, I believe, the American polar hare (Lepus arcticus) of naturalists, and in the State of Wyoming is only found at an altitude of from seven thousand to twelve thousand feet, and ascends even higher than the latter level, I believe, during the summer. At that time of year they are grey-brown; but in October, by which time their entire range is usually covered with snow, they become pure white, with the exception of the tips of their ears, which are always black. Their feet are covered with long hair, which nearly covers the pads and grows out to a considerable length on all sides, giving the animals a curious appearance, which has earned for them their local name, and which is an obvious provision of nature to enable them to travel easily in deep, soft snow. 
By the end of October, I 897 , the snow-shoe rabbits had all duly turned white, according to immemorial precedent; but the warm weather and unexpected melting of the snow during the following month must have rendered their white winter dress an added source of danger to them instead of a protection, and had there been more predatory animals and birds about, the species would doubtless have suffered heavily during that season.

I met with three species of hares in Wyoming: the mountain species I have just described, the large prairie hare, or jack rabbit, as it is called (Lepus campestris), and a small species about the size of a rabbit, which is, I think, the wood hare (Lepus sylvaticus). ${ }^{1} \quad$ The range of the latter overlaps the ranges of the other two, as it is not only found everywhere in the valleys and on the side-hills of the lower spurs of the Rocky Mountains, where neither the prairie hare nor the mountain species are to be met with, but is common far out on the plains of the Bighorn Basin, where the prairie hare is also numerous, and in winter, at any rate, also lives in the lowest valleys, to which the mountain hare descends. Both the prairie hare and the mountain hare turn snow-white in winter, but the little wood hare never changes colour, though one would imagine that protective colouring would be as necessary for it as for its larger congeners. Perhaps it was originally a southern species, evolved in countries

1 Local name, "cotton-tail." 
where the ground was not usually covered with snow in winter, and has gradually extended its range northwards, until it now overlaps that of two allied species, whose ancestors must have been evolved in an Arctic climate.

I shot my finest mule deer stag on November I6. Graham and I were following on the track of a wapiti bull pretty high up in the mountains, when we came on a doe mule deer feeding, and immediately afterwards saw a buck amongst some short scrub a little way to the left. Both animals were busy pawing up the snow to get at the herbage beneath, and neither of them had noticed us, so we crouched down and watched them. I did not want to give up the chance of getting a shot at the wapiti we were following slight though it was - for a small mule deer head, but I had no intention of losing a good chance of getting a really fine deer head if it came in my way. I soon saw that such a one was now almost within my grasp, for as the stag raised his head he showed such a beautiful pair of widespread antlers that Graham could not help whispering to me, "He's a real good 'un; you must have him."

The buck was not more than a hundred yards from us; but as his body was very much hidden by small spruce-trees, I waited for him to move forwards and give me a clear shot. This he soon did, and I immediately fired. At the shot he came rushing down the hillside in a series of prodigious leaps, and passed 
within thirty yards of where we were standing. I knew that I had had the sight just on the right place for a lung shot when I pulled the trigger, and moreover I felt certain that I had seen a spot of crimson on the buck's grey coat as he dashed past us down the mountain-side. I was therefore rather surprised when Graham said mournfully, "Well, that's a pity." "Why!" I said, "what's the matter? I'm sure the deer's dead. I hit him square through the lungs, and I don't think he's very far away now. If I'm not very much mistaken, he was in his death-rush when he went past us."

However, Graham did not think so. He said he thought I had hit him, but too high up, and doubted our ever setting eyes on him again. I felt quite confident, however, and as soon as we struck the tracks became more confident still, as the great quantity of blood on the snow - evidently thrown from the mouth and nostrils of the stricken beast - showed plainly enough that he had got the bullet through both lungs. The tremendous bounds hẹ had made were simply astonishing, even when the fact that he was going down a steepish incline was taken into consideration. But he had not gone far, and we found him lying stone dead within a very short distance of where we had last seen him. Graham was delighted, and assured me I had got as good a mule deer head as I was likely to get nowadays in the State of Wyoming, though I might still get bigger, he thought, in Colorado. 


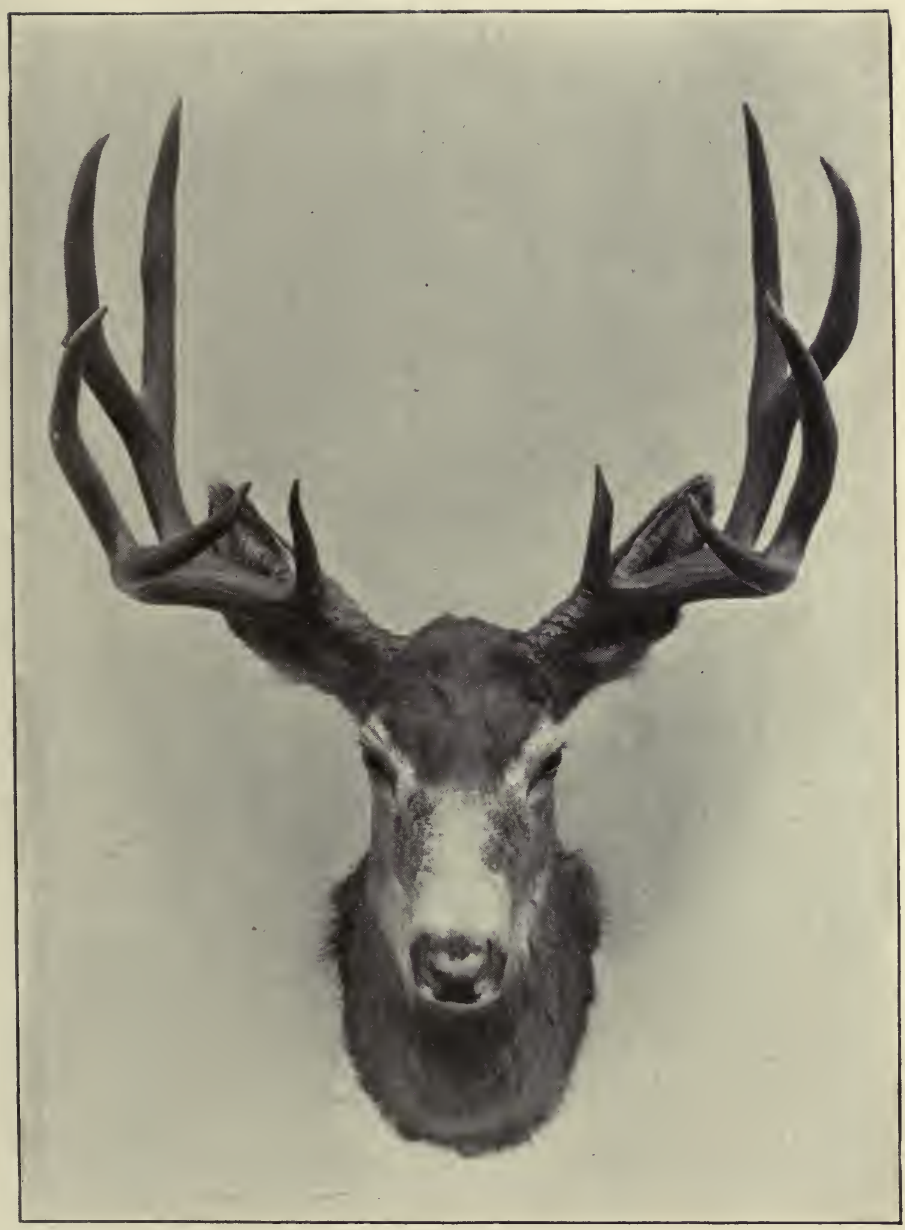

HEAD OF MULE DEER STAG

Shot on the North Fork of the Stinking Water River, November 16, 1898 
This stag was an extremely heavy, massive animal, with an immensely thick neck, the circumference of which, after the skin had been removed, I found to measure twenty-nine inches, midway between jaw and chest, and forty-seven inches just in front of the shoulders. We were so pleased at getting this fine buck deer that we abandoned the wapiti tracks, and set about getting the deer meat back to camp. After removing the head and neck skin, and collecting all the inside fat, we dragged the disembowelled carcass over the snow to the slope of the mountain overlooking the valley of the river on which we were camped, and then slid it down the hillside. It never went far without fetching up against a tree, from which it had to be cleared and started again. This mule deer stag, like the two previously shot, was excessively fat; but his great swollen neck, and the fact that the meat had a slight musky flavour about it, showed, I suppose, that he had either commenced to rut, or was just about to commence, though as yet he had lost nothing of his high condition.

Four days later I shot my fourth and last mule deer stag. Though not quite such a fine animal as the one whose capture I have just recounted, this was also a very big buck, with a handsome widespread head. We had determined to move camp to a side creek a little lower down the river; and as Graham was wanted to assist in packing, I went out in search of game by myself. I saw nothing all day, and late in the after- 
noon made my way to the mouth of the creek, where it had been arranged that our new camp should be pitched. Finding nothing there, and a brief examination of the level ground between the river and the sidehill assuring me that our pack train had not yet

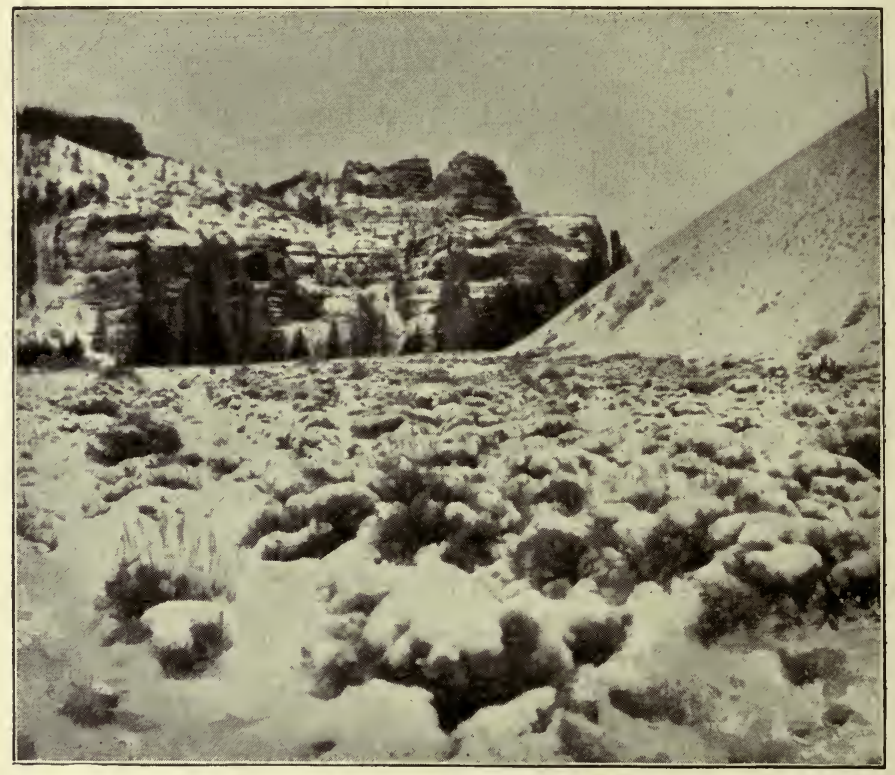

Scene near Camp after a Light Fall of Snow, November, i 898

passed, I concluded that something had happened to delay the shifting of our camp, and so started to walk back along the trail leading up the valley of the river, to where I had left my companions in the morning.

I was trudging along in the snow (for a few inches of new snow had fallen on the preceding night), and was just crossing a large open piece of ground, when I saw 
a fine buck mule deer about one hundred and eighty yards to my left. He was also in open ground walking along quite slowly just on the other side of the river. There was not a bush between us; and as I saw him, and immediately came to a halt, he must also have seen me, as he stopped and looked towards me. Seeing that there was no chance of getting any nearer to him, I at once sat down and prepared for a longish shot. But on his resuming his slow walk with head held high as if the whole country belonged to him, I thought I would let him get amongst some bushes a little farther down the river and then try to get nearer to him. However, after having taken a few steps only, he again halted and.looked towards me, and then turning half away from me walked towards a thick patch of wild raspberry bushes growing just under a steep shoulder of the mountain, which here rose abruptly from the valley on the farther side of the river.

I now judged it expedient to fire, and as I did so, not only heard my bullet thud, but saw that the old buck had received a mortal wound, for instead of bounding off he lowered his head, and stood swaying about, and I thought he was going to fall in his tracks. But he recovered a little and began to limp slowly forwards towards the raspberry bushes. Just as he was about to enter them, I fired at him again, and he dropped all of a heap, apparently dead.

By this time (November 20 ) the river, though it was 
a rushing mountain torrent, was completely frozen over in many places, and where, owing to the swiftness of the current, the water was still open, accumulations of ice were usually to be seen under water on the rocks and stones, looking like fungoid growths of a whitish colour. I had to go some three hundred yards down the river before I found a place where the ice looked strong enough to bear me right across the stream, and just before reaching this place I saw another mule deer buck on the hillside opposite to me. He was a fine big animal and carried a handsome head; but although he was somewhat nearer to me than the one I had just killed, I did not fire at him, as I could have made no use of the meat and had already got four good mule deer heads.

These two fine stags, the last I was destined to see on this trip, were both of them singularly tame and unsuspicious of danger, - a condition of mind possibly induced by the coming on of the rutting season; a period during which the males of many species of deer often become very bold and even aggressive. The mule deer on the hillside above me stood watching curiously as I crossed the river on the ice, and then walked slowly and unconcernedly into the shelter of a cluster of spruce fir trees, after which I saw him no more. I found the stag I had shot lying where I had seen him fall, but, contrary to my expectation, he was not dead. Not wanting to cut his throat or fire another shot into him, I seized him by one horn, 
and bending his head forwards, tried to pith him, as I had done with many an African antelope, by sticking my small sharp knife into the spinal column, between the back of the skull and the first vertebra.

Directly, however, he felt the point of the knife on his skin, he struggled to his feet and stood facing me. I held him by both horns with all my strength and tried to keep his head down, and for some moments my strength was just equal to his. But with a last supreme effort the dying stag brought all the muscles of his great neck into play, and, throwing up his head shook my hands from his horns, causing the blade of my knife, which I held in my right hand, together with his left horn, to cut deep into the inside of one of my fingers. Expecting a plunge forwards, which might have been serious, as all the tines of a mule deer's horns point forwards, I jumped to one side, but the exhausted stag never moved its feet, but just sank down again on its knees in the snow. I then killed it with a bullet through the lungs. My first bullet had, I found, struck it in the right flank, behind the ribs, and after passing obliquely forwards through its body had broken the left shoulder, the expanded bullet remaining just under the skin.

As I was gralloching the deer, I saw our pack train passing down the valley on the farther side of the river, but did not call out for one of the men to come and help me, as I did not wish to cause any delay in getting our camp pitched, for it was already late and fast 
growing dusk. As soon as I had cleaned the carcass and laid it belly downwards on the snow, I started for camp, carrying the head cut off with a good long neck skin, and all the inside fat with me. In recrossing the river I got on to a piece of thin ice, and went through. As the depth of water was under three feet, not much

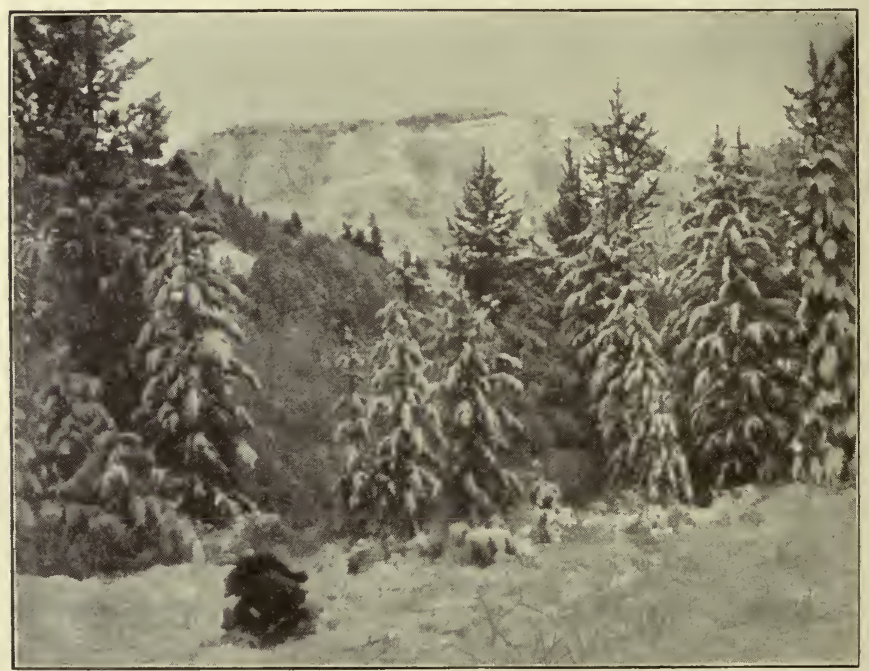

Scene of our Night's Bivouac in the Snow, November 20, I898

harm was done, though it was uncomfortable, as the temperature of the air was just then well below zero.

By the time I rejoined my companions about two miles lower down the river, it would have been quite dark, had it not been for the light of the moon, which shone most brilliantly, from a clear and cloudless sky, over the snow-covered landscape. I found them pre- 
paring for the night's bivouac in the shelter of a thick pine grove near the river's edge. The delay in starting from the old camp had, I found, been caused by the impossibility of packing the frozen tents on the horses until they had been thawed by means of huge $\log$ fires. Now we found that the damp bundles into which they had been rolled had been again frozen solid, so that all hope of repitching the tents for the night had to be abandoned. Fortunately, it was a perfectly fine night, though colder than any we had yet experienced.

As soon as I had changed my wet nether garments for dry ones, I got out my large thermometer and hung it on a tree away from the fire. It soon registered thirteen degrees below zero, forty-five degrees of frost, and Graham confidently predicted that it would go down to minus twenty degrees before morning. However, it did not do so, and although the temperature remained at thirteen degrees below zero until after daylight in the morning, it never went any lower, which much disappointed me, as I had hoped to experience much greater cold than this. After we had had supper, we each of us spread the tarpaulin, in which our blankets were wrapped, on the snow-covered ground, and turned in. I lay on my sleeping bag, with a Hungarian sheepskin coat and two Jaeger blankets over me, and kept very warm and comfortable all night.

After this I was only able to devote four more 
days to hunting, as it was important to me to get back to England by the middle of December, and to do that I had to make a start on November 25 .

I hunted hard these last four days, but had no luck; for though we got fresh wapiti bull tracks every day, and always got sufficiently near to where the

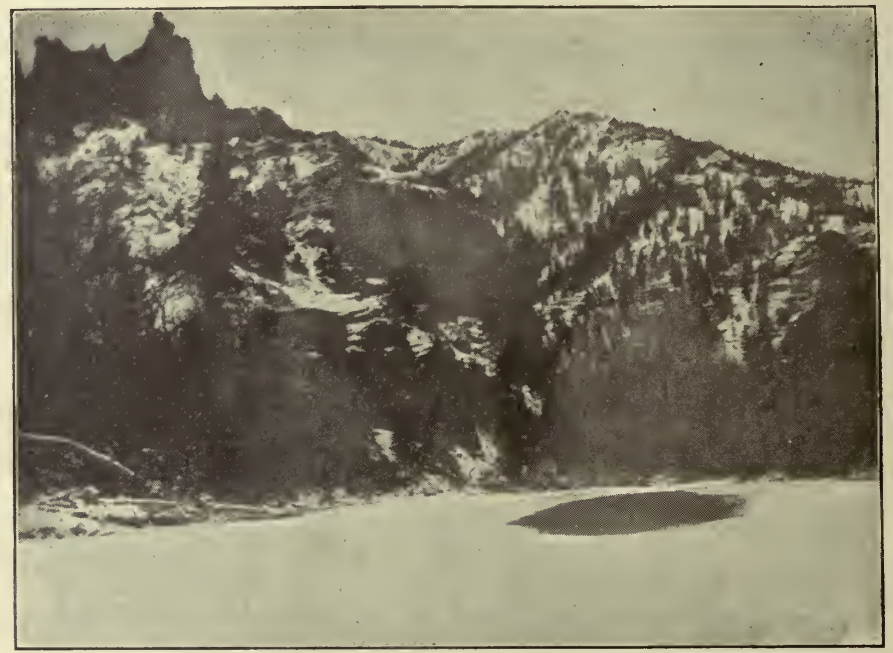

Open Water-Hole near Camp in the Frozen River

wary beasts had been lying to frighten them from their beds, we never caught a glimpse of any one of them, owing to the thickness of the timber. Neither did I see another mule deer buck, though I came across a few does and fawns. On the twenty-fifth I started for home, carrying with me as the result of three weeks' hunting, two wapiti and four mule deer heads, a bag with which I should have been amply satisfied, had 
the wapiti heads been really good ones. They were not, however, as large as I had expected to get, and in that respect my trip was a disappointing one; but on the other hand two of the mule deer heads were finer than anything I had hoped to obtain, and these alone were an ample reward for the long journey to and from the Rocky Mountains, whilst the time spent in the mountains themselves, the taste of the wild free life, the glorious air, and the magnificent scenery through which I had daily wandered, rifle in hand, I cannot look upon as time ill spent, even though I never got a shot at the great wapiti bull of my imagination, nor saw a single specimen of a mountain sheep.

My journey home was uneventful, and I finally landed in England on December I6, after an absence of exactly two months. 






\section{UNIVERSITY OF CALIFORNIA LIBRARY}

This book is DUE on the last date stamped below.

Fine schedule: 25 cents on first day overdue 50 cents on fourth day overdue One dollar on seventh day overdue.

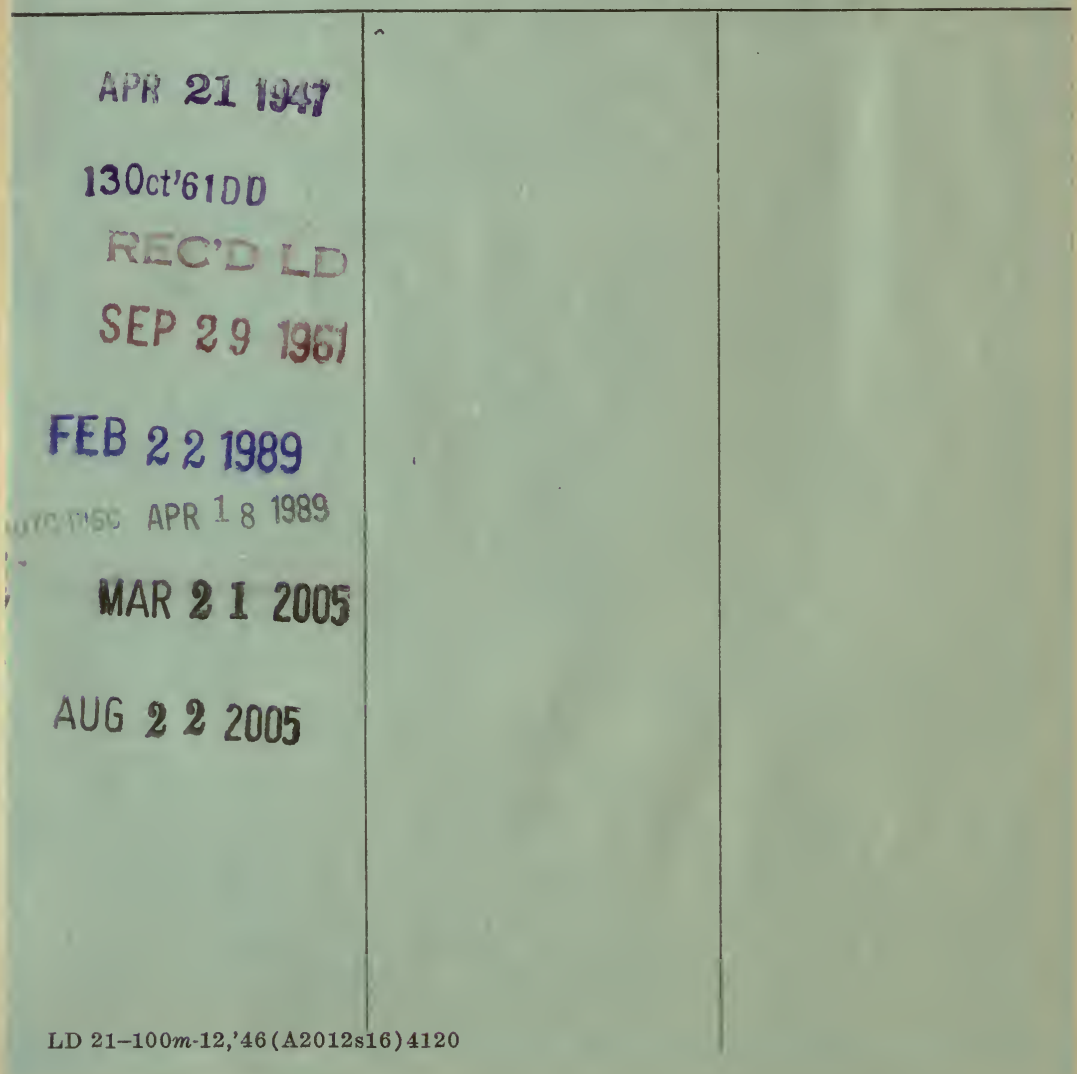




\section{U.C. BERKELEY LIBRARIES}
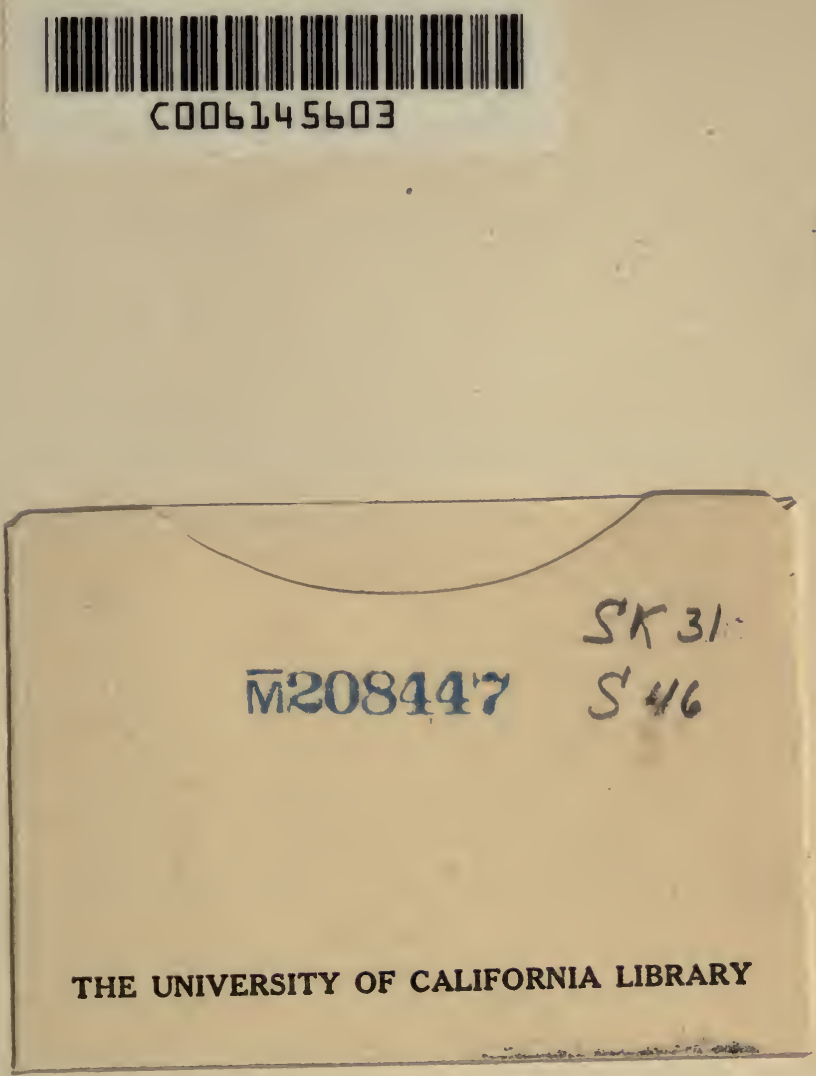
